Sediment impacts on sponges and a deep-sea coral in New Zealand

\author{
Valeria Mobilia
}

\begin{abstract}
A Thesis
submitted to the Victoria University of Wellington in fulfilment of the requirements for the degree of Doctor of Philosophy
\end{abstract}

2021

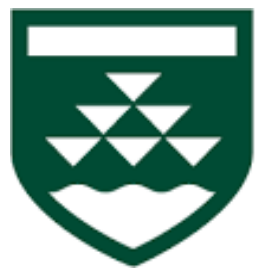

VICTORIA UNIVERSITY OF

WELLINGTON

TE HERENGA WAKA 
This thesis was conducted under the supervision of

\section{Professor James J. Bell}

(Primary supervisor, Victoria University of Wellington

Wellington, New Zealand)

$\&$

\section{Dr. Vonda Cummings}

(Co-supervisor, National Institute of Water and Atmospheric Research - NIWA Wellington, New Zealand)

$\&$

\section{Ms. Di Tracey}

(Co-supervisor, National Institute of Water and Atmospheric Research - NIWA Wellington, New Zealand)

$\&$

\section{Dr. Malcolm Clark}

(Co-supervisor, National Institute of Water and Atmospheric Research - NIWA Wellington, New Zealand) 


\begin{abstract}
Increased levels of suspended sediment in the water column are important factors contributing to the degradation of marine ecosystems worldwide. In coastal waters, temporal variation in suspended sediment concentrations (SSCs) occurs naturally due to seasonal and oceanographic processes. However, there is evidence that anthropogenic activities are increasing sediment concentrations. The volume of sediment moving from land-based sources into coastal ecosystems and human activities in the ocean disturbing the seafloor, such as dredging and bottom-contact fisheries, have been increasing over the last century. In addition, offshore activities, particularly bottom-contact fishing and potential deep-sea mining, can create sediment plumes in the deep-sea that may extend over long distances. Elevated suspended sediment concentrations have detrimental effects on benthic communities, particularly for suspension feeders like sponges and corals.
\end{abstract}

The aim of this thesis was to investigate the effects of increased SSCs that might arise from heavy anthropogenic disturbance on common shallow water and deep-sea sponges and a deepsea coral in New Zealand, as these groups contribute to habitat structure in some benthic environments, including the deep sea.

In my first data chapter, I explored the responses (survival, respiration rates, clearance rates) of the common New Zealand shallow-water sponge, Crella incrustans, during a four week exposure to a gradient of suspended sediment concentrations up to $832 \pm 71 \mathrm{mg} \mathrm{l}^{-1}$ (SE), and the recovery potential of this species two weeks after the sediment stress had ceased. Survival was high (94\%), and respiration rates were not affected at any time point. Sponges accumulated sediment internally during the sediment exposure period; sediment particles were partially cleared during the two-week recovery period. In addition, sponges developed apical fistules, likely as a response to sediment accumulated internally or on the sponge surface. These results, indicate no evidence of negative impacts of elevated SSCs on C. incrustans, suggesting a tolerance to high SSC, likely as a pre-adaptation to the occasional turbidity that occurs in its natural habitat.

In my second data chapter, I explored the responses of the New Zealand deep-sea sponge Ecionemia novaezealandiae to suspended sediment concentrations expected from intense anthropogenic seafloor disturbance, such as bottom trawling and potential deep-sea mining. I investigated survival and sublethal effects, including respiration rates and necrosis. After two weeks of sediment exposure, one sponge (12\%) died in the highest sediment treatment, and 25 
and $50 \%$ of the sponges in the 100 and $500 \mathrm{mg} \mathrm{l}^{-1}$ SSC treatments, respectively, showed necrosis. Respiration rates of treatment sponges were lower than control sponges after one and 14 days of sediment exposure, however only respiration rates of sponges in the $500 \mathrm{mg}^{-1} \mathrm{SSC}$ treatment were significantly affected after one day of sediment exposure. Sponge sectioning revealed the presence of sediment particles in the tissue of all specimens, including controls, indicating incorporation of sediment in their natural environment. Although survival was high, the sublethal effects observed (partial necrosis, decreased respiration rates) suggest that longer exposure might be deleterious to this species.

In my third data chapter I explored the responses of the habitat-forming New Zealand deep-sea coral Goniocorella dumosa to 4-day pulses of SSCs consistent with that expected from bottom trawling activities and potential deep-sea mining. I assessed survival, respiration, and sublethal effects (polyp and partial tissue mortality). All coral fragments survived. After one sediment pulse, oxygen consumption rates were elevated in the 100 and $500 \mathrm{mg} \mathrm{l}^{-1} \mathrm{SSC}$ treatment corals compared to the control and the $50 \mathrm{mg} \mathrm{l}^{-1}$ treatment corals, however, this response did not persist. After the second and third sediment pulse treatments, respiration rates were similar to the controls. No detrimental effects were visible after the first pulse of sediment exposure, while partial coenosarc loss and partial polyp mortality affected some treatment corals fragment during the subsequent sampling time points, although these effects were not statistically significant. Despite coral survival not being affected by the treatments, the reduced health condition over time indicates that while G. dumosa can survive intense sediment disturbance from human activities for periods up to 4 days, repeated exposure will increasingly reduce the health of this species.

In the fourth data chapter, I exposed $G$. dumosa to the same SSCs used in chapter 4 continuously for four weeks, and I used histology to explore whether $G$. dumosa ingests sediment particles and whether exposure to high suspended SSCs causes structural damage to this species. Histological sections of the polyps did not reveal the presence of sediment particles internally, indicating that $G$. dumosa does not ingest sediment particles actively or accidentally. This finding indicates that this species might cease feeding during the whole period of sediment exposure. Furthermore, no tissue or cellular damage were identified in the sections of the polyps sampled.

In conclusion, all three species I studied showed high or total survival when exposed to extremely elevated SSCs that they might experience under intense anthropogenic disturbance. 
However, while $C$. incrustans was not affected by high SSCs, E. novaezealandiae and $G$. dumosa showed sublethal effects, including reduced respiration rates (E. novaezealandiae) and partial necrosis (E. novaezealandiae and G. dumosa). The sublethal effects recorded in $E$. novaezealandiae and G. dumosa highlight the importance of developing regulations to manage activities that might create intense seafloor disturbance in proximity to areas where these species occur. 
Ai miei genitori: Paolo e Fifetta 


\section{Acknowledgments}

Firstly, I wish to thank my supervisors, Professor James Bell, Dr Vonda Cummings, Ms Di Tracey and Dr Malcolm Clark. I am extremely grateful to James for always encouraging me during the challenges I encountered in my research, as well as for providing endless feedback on manuscripts. All my supervisors have given me immense guidance, constructive feedback on manuscripts and drafts as well as support during the challenges of my $\mathrm{PhD}$. All of them are inspiring scientists and I feel privileged to have learned from them. I am also thankful to the members of our research group, the "Sponge Club", from which we learned from each other.

I am very thankful to Victoria University of Wellington Doctoral, Submission and Hardship Scholarship that have provided stipend support and covered enrolment fees. I would also like to thank the ROBES project, which provided funding for my research on deep-sea sponges and corals.

I would like to thank Megan and Albi for sampling the sponges for my second chapter; Dr Lisa Woods for the statistical assistance; Dr Neill Barr, for the creation of the system where I carried my experiments and the system for maintaining live samples while at sea; Graeme Moss for the great help in setting up the MEMF; Jenny Beaumont for her guidance and lab help during the experiment in my second chapter; Peter Marriott for providing the photography equipment and help; lab technician Neville for the creation of the respiration chambers and Tangaroa Crew for the assistance during my two fieldtrip. A big thank goes to Sandeep who helped me in the lab for final sampling for chapter 3 while I was injured.

I am endlessly grateful to my family, who supported me to move to the other side of the world and kept supporting me despite the difficult times of the past two years, and a huge thank to my sister Flaviana for taking care of mum and dad during these times. Finally, the biggest and special thank to you, Alex: this thesis would not exist without your immense support. 


\section{Chapter contributions and Publications}

\section{Chapter 2:}

Study design: Valeria Mobilia, Prof. James J. Bell (Victoria University of Wellington VUW- New Zealand), Dr Vonda J. Cummings (National Institute of Water and Atmospheric Research - NIWA - New Zealand). In addition, Dr Jennifer Beaumont, Dr Malcolm Clark and Ms Dianne Tracey (National Institute of Water and Atmospheric Research - NIWA New Zealand) contributed to discussion of the study design.

Data collection: VM

Data analysis: VM., with assistance from VJC.

Chapter writing and editing: VM, with inputs from VJC, JB, MC, DT.

Part of the material from this chapter was published in: Cummings, V., Beaumont, J., Mobilia, V., Bell, J.J., Tracey, D., Clark, M.R., Barr, N. (2020). Responses of a common New Zealand coastal sponge to elevated suspended sediments: Indications of resilience. Marine Environmental Research, 155, 104886.

\section{Chapter 3:}

Study design: VM with guidance from JJB, VJC, MC.

Data collection: VM

Data analysis: VM, with assistance from Dr Lisa Woods (VUW).

Writing and editing: VM with the guidance of JJB, VJC, MC and DT.

Publication: Mobilia, V., Cummings, V.J., Clark, M., Tracey, D., Bell, J.J. Short-term physiological responses of the New Zealand deep-sea sponge Ecionemia novaezealandiae to elevated concentrations of suspended sediments. Journal of Experimental Marine Biology and Ecology, 541: 151579.

\section{Chapter 4:}

Study design: VM with guidance from JJB, VJC, MC.

Data collection: VM

Data analysis: VM, with assistance from Dr. Lisa Woods (VUW). 
Writing and editing: VM with the guidance of JJB, VJC, MC and DT.

In prep.

\section{Chapter 5:}

Study design: VM with guidance from JJB, VJC.

Data collection: VM

Writing and editing: VM with the guidance of JJB, VJC, MC and DT.

In prep, combined with chapter 4. 


\section{Table of contents}

List of figures 17

List of tables $\quad 22$

Chapter 1: General Introduction $\quad 24$

1.1 Sediment impacts in coastal waters 24

1.2 Sediment impacts in the deep sea 26

$\begin{array}{ll}1.3 \text { Sponges } & 27\end{array}$

1.3.1 Ecological importance of sponges 29

1.3.2 Sponges in shallow-water reefs 30

1.3.3 Sponges in deep-water reefs 30

1.3.4 Sediment impacts on sponges 31

1.4 Scleractinian corals 33

1.4.1 Deep-sea scleractinian corals 34

1.4.2 Sediment impacts in deep-sea scleractinian corals 36

1.5 New Zealand region (study site) 36

$\begin{array}{ll}\text { 1.5.1 Shallow-water site } & 37\end{array}$

1.5.2 Deep-water site $\quad 37$

1.6 Aims 38

$\begin{array}{ll}\text { References } & 40\end{array}$

Chapter 2. Responses of the common New Zealand coastal sponge, Crella incrustans, to elevated suspended sediments. $\quad 60$

$\begin{array}{ll}\text { Abstract } & 60\end{array}$

2.1 Introduction $\quad 60$

2.2 Material and methods $\quad 63$

2.2.1 Sponge collection and maintenance 63

2.2.2 Experimental chambers 63

2.2.3 Sediment treatments 65

$\begin{array}{ll}\text { 2.2.4 Sponge responses } & 67\end{array}$

$\begin{array}{ll}\text { 2.2.4.1 Respiration rates } & 67\end{array}$

2.2.4.2 Morphology 68

2.2.4.3 Feeding efficiency $\quad 69$

$\begin{array}{ll}2.2 .5 \text { Statistical analysis } & 70\end{array}$

$\begin{array}{ll}2.3 \text { Results } & 70\end{array}$

$\begin{array}{ll}\text { 2.3.1 Survival } & 70\end{array}$ 
2.3.4 Feeding efficiency 74

$\begin{array}{ll}2.4 \text { Discussion } & 75\end{array}$

2.4.1 Respiration rates 75

2.4.2 Morphology 76

2.4.3 Feeding efficiency 77

2.4.4 Tolerance of coastal temperate sponges to sediment 78

$\begin{array}{ll}2.5 \text { Conclusions } & 78\end{array}$

$\begin{array}{ll}\text { References } & 79\end{array}$

Chapter 3. Short-term physiological responses of the New Zealand deep-sea sponge Ecionemia novaezealandiae to elevated concentrations of suspended sediments $\quad 88$

$\begin{array}{ll}\text { Abstract } & 88\end{array}$

3.1 Introduction $\quad 88$

3.2 Materials and methods $\quad 91$

3.2.1 Sponge collection and maintenance $\quad 91$

3.2.2 Sediment treatments 92

3.2.3 Sediment collection and manipulation $\quad 92$

3.2.4 Experimental aquaria 93

3.2.5 Sponge response measures $\quad 94$

3.2.5.1 Respiration rates 95

3.2.5.2 Necrosis and sediment accumulation 96

3.2.6 Statistical analysis $\quad 96$

$\begin{array}{ll}3.3 \text { Results } & 97\end{array}$

3.3.1 Sediment treatments 97

3.3.2 Respiration rates $\quad 97$

3.3.3 Sponge survival and health 99

3.3.4 Sediment coverage $\quad 99$

3.3.5 Sediment incorporation 101

3.4 Discussion 103

3.4.1 Survival and health 103

3.4.2 Respiration rates 104

3.4.3 Sediment incorporation 106

3.4.4 Sediment coverage 107

$\begin{array}{ll}3.5 \text { Conclusions } & 107\end{array}$ 
References

Chapter 4. Suspended sediment impact on the deep-sea coral Goniocorella dumosa

Abstract

4.1 Introduction

4.2 Materials and Methods

4.2.1 Corals collection and maintenance

4.2.2 Sediment treatments 121

4.2.3 Sediment collection and manipulation 121

$\begin{array}{lll}\text { 4.2.4 Coral responses } & 122\end{array}$

4.2.4.1 Respiration Rates 123

4.2.4.2 Polyp mortality and coenosarc loss 123

4.2.5 Statistical analysis $\quad 124$

$\begin{array}{ll}4.3 \text { Results } & 124\end{array}$

4.3.1 Polyp survival 124

4.3.2 Coenosarc loss 125

4.3.3 Respiration rates 127

$\begin{array}{ll}4.4 \text { Discussion } & 128\end{array}$

4.4.1 Polyp mortality and coenosarc loss $\quad 129$

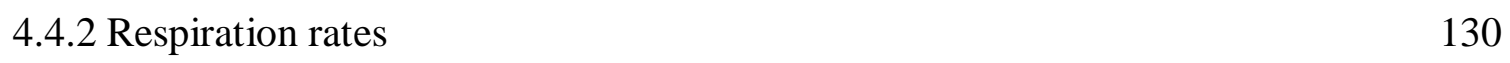

4.5 Conclusions $\quad 132$

References 133

Chapter 5. Histological assessment of Goniocorella dumosa exposed to elevated suspended $\begin{array}{ll}\text { sediment concentrations } & 140\end{array}$

$\begin{array}{ll}\text { Abstract } & 140\end{array}$

5.1 Introduction 140

5.2 Materials and methods 142

5.2.1 Sediment treatments 142

5.2.2 Histological preparation 143

5.3 Results 143

$\begin{array}{ll}5.4 \text { Discussion } & 148\end{array}$

5.4.1 The lack of sediment particles: implications 148

5.4.2 Lack of structural damage 149

$\begin{array}{ll}5.5 \text { Conclusions } & 150\end{array}$

References $\quad 152$

6. General discussion and conclusions 155 
6.1 Summary of key findings 155

6.2 Relationships with sediments 156

6.3 Physiological responses of sediment rejection mechanisms 157

6.3.1 Sediment rejection mechanisms in sponges 157

6.3.2 Sediment rejection mechanisms in G. dumosa 158

6.4 Research limitations $\quad 159$

6.5 Future directions 160

$\begin{array}{ll}\text { 6.5.1 Sediment impacts on juvenile and larval stages } & 160\end{array}$

6.5.2 The energetic cost of coping with high suspended sediment concentrations $\quad 160$

$\begin{array}{ll}\text { 6.5.3 Cumulative impacts } & 161\end{array}$

6.6 Management implications and concluding remarks $\quad 161$

$\begin{array}{ll}\text { References } & 164\end{array}$

$\begin{array}{ll}\text { Appendices } & 169\end{array}$

$\begin{array}{ll}\text { Appendix one } & 170\end{array}$

$\begin{array}{ll}\text { Appendix two } & 173\end{array}$

$\begin{array}{ll}\text { Appendix three } & 178\end{array}$

Marine Environmetal Research publication

Journal of Experimental Marine Biology and Ecology publication 


\section{List of figures}

Figure 1.1. Schematic representation of sponge body plan and water pumping mechanism (Campbell \& Reese, 2002).

Figure 1.2. Anatomy of a scleractinian coral polyp. Picture taken from Galloway et al., (2007).

Figure 2.1. Schematic of an experimental chamber (38 1), showing details of the mechanisms used to keep sediments in suspension.

Figure 2.2. The range of suspended sediment concentrations (SSC) used in the experiment. Data presented are means (+ SE) of samples taken from a chamber on four separate occasions

Figure 2.3. Schematic representation of the experimental sampling design. Each square represents a sediment chamber, dots represent sponge samples inside the chambers. Grey dots represent sponges sampled at each time point....

Figure 2.4. Respiration rates of Crella incrustans after 8 (A), 23 (B), 30 (C) days of sediment exposure and after a two-week recovery period in ambient seawater (D). Best fit lines and $\mathrm{R}^{2}$ values for the relationship with SSCs at each time point are shown.... .71

Figure 2.5. Number of fistules $\mathrm{cm}^{-2}$ on the surface of sponges sampled after 8 (A), 23 (B), 30 (C) days of sediment exposure and after a two-week recovery period in ambient seawater (D). Best fit lines and $\mathrm{R}^{2}$ values for the relationship with SSCs are shown. .72

Figure 2.6. Image of the surface of a sponge after 30 days exposure to SSC of $170 \mathrm{mg}^{-1}$, showing fistules protruding from sediment that had settled on the sponge surface .73

Figure 2.7. Images of cross-sectioned sponges showing the accumulation of sediments. Examples are shown of control and sediment-exposed sponges after 8 days and 30 days, and at 44 days. .74

Figure 2.8. Particle retention by $C$. incrustans after 8 (A), 23 (B), 30 (C) days of sediment exposure and after two-week recovery period in ambient seawater (D). Best fit lines are shown 
and $\mathrm{R}^{2}$ values for the relationships with $\mathrm{SSCs}$ at each time point are shown.

Figure 3.1. Schematic of an experimental chamber used in this study. Direction of water flow is shown by the arrows. The auger, driven by the motor, creates an upward water flow into the central PVC pipe. This flow resuspends and pushes the sediment accumulating at the bottom of the chamber up the pipe and back into the chamber through the holes near the top of the pipe.

Figure 3.2. Schematic representation of the experiment sampling design. Squares represent sediment chambers, dots represent sponge samples. Grey dots represent sponges sampled at $\mathrm{T}_{1}$ and $\mathrm{T}_{14}$

Figure 3.3. Respiration rates of Ecionemia novaezealandiae in each of the experimental treatments after one $\left(\mathrm{T}_{1}\right)$ and $14\left(\mathrm{~T}_{14}\right)$ days of exposure. Bars show mean values $(\mathrm{SE}) . \mathrm{N}=4$. $\begin{array}{llll}\text { Asterisks indicate where differences } & \text { sificant }\end{array}$ occur 98

Figure 3.4. Section of treatment sponge showing a portion of necrosed tissue (circled in black). This sponge was in the $500 \quad \mathrm{mg} \quad 1^{-1}$ SSC treatment

Figure 3.5. Sediment layer covering Ecionemia novaezealandiae after A) one day of sediment exposure and B) 14 days of sediment exposure. This sponge was in the $100 \mathrm{mg}^{-1} \mathrm{SSC}$ treatment 100

Figure 3.6. Percentage of the surface of Ecionemia novaezealandiae covered by sediment in each of the experimental treatments after one $\left(\mathrm{T}_{1}\right)$ and $14\left(\mathrm{~T}_{14}\right)$ days of exposure. Bars show mean values $(\mathrm{SE}) . \mathrm{N}=4$. Asterisks indicate where significant differences occur 101

Figure 3.7. Transverse section images of sponge interior at $T_{\text {end }}$ showing sediment within a control sponge (A) and a sponge from the $500 \mathrm{mg}^{-1}$ treatment (B). Red asterisks indicate sponge upper surface

Figure 3.8. Scatterplot showing percentage of inorganic content of experimental sponges from each treatment. $\mathrm{N}=4$ 
Figure 4.1. Distribution map of Goniocorella dumosa around New Zealand waters (yellow dots). Figure taken from Tracey et al. (2019)

Figure 4.2. Schematic of the experiment showing the sediment exposure regime with 3 cycles of four-days sediment exposure alternated with five days of non-sediment exposure periods (A), and representation of the coral sampling design (B). Squares represent sediment chambers and dots represent coral fragments inside the chambers, grey dots represent coral fragments sacrificed at each sampling time point $(B) . T_{1}, T_{2}, T_{3}$ and $T_{4}$ indicate sampling time points.

Figure 4.3. Image of Goniocorella dumosa fragment in the $500 \mathrm{mg}^{-1} \mathrm{SSC}$ treatment at $\mathrm{T}_{0}$ (A) and at $\mathrm{T}_{2}$ (B). White circles indicate a healthy (A) and dead polyp filled with sediment (B).

Figure 4.4. Percentage of coenosarc loss (\%), in Goniocorella dumosa, in each of the suspended sediment concentration (SSC) treatments, at each sampling time point $\left(\mathrm{T}_{1}=4, \mathrm{~T}_{2}=\right.$ 13, $\mathrm{T}_{3}=22, \mathrm{~T}_{4}=27$ days $)$. Bars show mean values $( \pm \mathrm{SE}) . \mathrm{N}=4$ .126

Figure 4.5. Image of Goniocorella dumosa fragment in the $500 \mathrm{mg}^{-1} \mathrm{SSC}$ treatment at $\mathrm{T}_{0}$ (A) and at $\mathrm{T}_{4}$ (B). White arrows indicate dead polyps with adjacent coenosarc loss (B).

Figure 4.6. Respiration rates of Goiocorella dumosa in each of the suspended sediment concentration (SSC) treatments at each sampling time point $\left(\mathrm{T}_{1}=4, \mathrm{~T}_{2}=13, \mathrm{~T}_{3}=22, \mathrm{~T}_{4}=27\right.$ days). Bars show mean values $\quad$ (SE). $\quad \mathrm{N}=4$ .128

Figure 5.1. Histological section of a portion of Goniocorella dumosa tentacle showing: epidermis, mesoglea (me), mucocyte cells $(\mathrm{mu})$ and spirocyst cells $(\mathrm{sp})$. Scale bar $=50$ $\mu \mathrm{m}$.

Figure 5.2. Histological sections of Goniocorella dumosa epidermis after 5 (A-D) and 28 (E$\mathrm{H}$ ) days of sediment exposure, showing integrity of cells and tissue structure. Sections of all treatment corals are shown: control (A, E), $50 \mathrm{mg}^{-1}(\mathrm{~B}, \mathrm{~F}), 100 \mathrm{mg} \mathrm{l}^{-1}(\mathrm{C}, \mathrm{G})$ and $500 \mathrm{mg}$

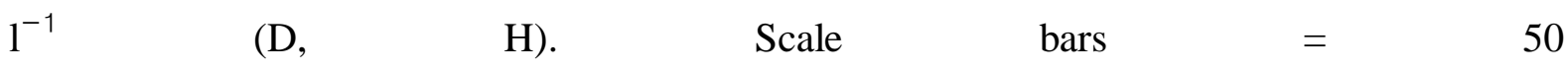
$\mu \mathrm{m}$ 146 
Figure 5.3. Longitudinal sections of a Goniocorella dumosa polyp showing the presence of larvae in control (A) and $500 \mathrm{mg} \mathrm{l}^{-1}$ treatment coral (B) polyps. Larvae are indicated by arrows; sections are stained with haematoxylin and eosin. Scale bars $=200 \mu \mathrm{m}$.

Figure A1.1. Scatterplot and linear regression of the relationship between voltage and SSCs determined prior to the experiment. $\mathrm{y}=25.532+245.1305 \mathrm{x}$

Figure A1.2. Particle size distribution (\% composition) of suspended sediments in treatments of high SSC chambers, near the beginning (Day 5) and end (Day 29) of the elevated SSC portion of the experiment. An average of five chambers (SE) are presented on each sampling date. Distribution categories equate to particle sizes generated in GRADISTAT: Clay $<4 \mu \mathrm{m}$, Fine silt 4-8 $\mu \mathrm{m}$, Medium silt 8-16 $\mu \mathrm{m}$, Coarse silt 16-31 $\mu \mathrm{m}$, Very coarse silt 31-63 $\mu \mathrm{m}$, Very fine sand $\quad 63-125 \quad \mu \mathrm{m}, \quad$ Fine $125-250$ $\mu \mathrm{m}$.

Figure A1.3. Baseline respiration rates of Crella incrustans measured in $\mathrm{N}=12$ extra sponge samples before the experiment start .172

Figure A2.1. Particle size distribution (\% composition) of sediments used in the experiment. Distribution categories correspond to particle sizes generated in GRADISTAT: Clay $<2 \mu \mathrm{m}$, Very fine silt 2-4 $\mu \mathrm{m}$, Fine silt 4-8 $\mu \mathrm{m}$, Medium silt 8-16 $\mu \mathrm{m}$, Coarse silt 16-31 $\mu \mathrm{m}$, Very coarse silt 31-63 $\mu \mathrm{m}$, Very fine sand 63-125 $\mu \mathrm{m}$, Fine sand 125-250 $\mu \mathrm{m}$ 175

Figure A2.2. Scatterplot and linear regression of the relationship between voltage and SSCs. $\mathrm{y}=0.3061+956.97 x \cdot \mathrm{R}^{2}=0.95$.

Figure A2.3. Scatterplot and linear regression fitted line of ash free dry weights (g), as a function of buoyant weight $(\mathrm{g})$, obtained from experimental sponges at $\mathrm{T}_{\text {end. }} \mathrm{R}^{2}=0.94$. $\mathrm{Y}=$ $0.44063+0.85049 \mathrm{x}$. Colours represent sponges from different treatments $(\mathrm{N}=8)$.

Figure A2.4. Suspended sediment concentrations over the 14-day experimental period. SSCs were derived from twice daily turbidity measurements, via the calibration curve shown in Figure A2.4. Lines and shaded areas indicate mean values (SD) .177 
Figure A3.1. Scatterplot and linear regression fitted line of the relationship between voltage

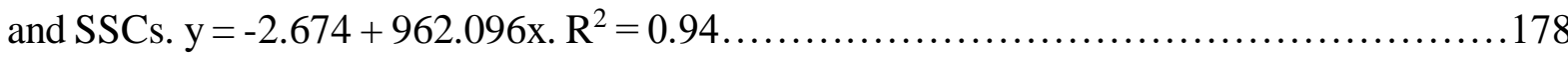

Figure A3.2. Scatterplot and linear regression fitted line of ash free dry weights ( $g$ ) as a

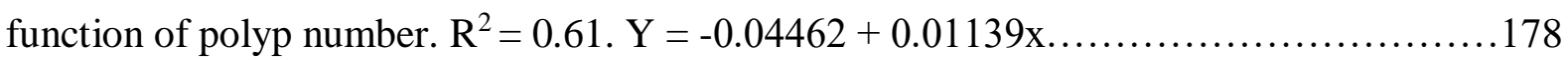




\section{List of tables}

Table 2.1. ANOVA table and summary of General Linear Model tests investigating the effects of SSCs on Crella incrustans respiration rates (A) number of fistules (B) and feeding efficiency (C). $\mathrm{DF}=$ degrees of freedom; $\mathrm{SS}=$ sum of squares; $\mathrm{MS}=$ mean square. Significant values are shown in bold .71

Table 3.1. ANOVA table and summary of General Linear Mixed Model assessing the effects of SSC and time on (A) respiration rates; and (B) sediment coverage of Ecionemia novaezealandiae $. \mathrm{DF}=$ degrees of freedom, $\mathrm{DFD}=$ degrees of freedom denominator, $\mathrm{SS}=$ sum of squares, MS = mean squares. Significant values are shown in bold .98

Table 3.2. Results of one-way ANOVA investigating the influence of the SSC treatment on Ecionemia novaezealandiae inorganic content. DF = degrees of freedom, $\mathrm{SS}=$ sum of squares, $\mathrm{MS}=$ mean square 102

Table 4.1. Total number of polyps and number of dead polyps in each of the sediment concentration treatment $\left(0,50,100,500 \mathrm{mg} \mathrm{l}^{-1}\right)$ at each sampling time point $\left(\mathrm{T}_{1}, \mathrm{~T}_{2}, \mathrm{~T}_{3}\right.$, $\left.\mathrm{T}_{4}\right)$ 125

Table 4.2. ANOVA table and summary of Linear Regression Model assessing the effects of SSC and Time on the percentage of coenosarc loss on responsive Goniocorella dumosa fragments. $\mathrm{DF}=$ degrees of freedom, $\mathrm{SS}=$ sum of square, $\mathrm{MS}=$ mean squares

Table 4.3. Summary of sediment effects on respiration rates of different coral species

Table 5.1. Summary of literature describing tissue and cellular damage induced by sediments in shallow-water corals.

Table A2.1. Linear mixed model results for the random effects "Sponge" and "Chamber" for A) respiration rates and $\mathrm{B}$ ) sediment coverage. $\mathrm{SD}=$ Standard deviation. 173

Table A2.2. Tukey post hoc pairwise comparison between SSC treatments, SSC treatments*Time and Time for sponge respiration rates.

Table A2.3. Tukey post hoc pairwise comparison between A) SSC treatments and B) Time for sponge sediment coverage 


\section{Chapter 1: General Introduction}

\subsection{Sediment impacts in coastal waters}

Over the past century, many coastal seas have undergone considerable changes due to human exploitation of resources, transformation of habitats, and pollution (Lotze et al., 2006; Pawar 2016). Exploitation of natural resources in certain regions is having a significant impact on the world's oceans (Keller et al., 2009), and it has been estimated that at least $40 \%$ of the global oceans are heavily affected by human activities (IOC/UNESCO 2011). Among the factors that have contributed to the degradation of marine ecosystems, increases in suspended sediment concentrations (SSCs) are considered to be having a major impact worldwide (Selman et al., 2008; Brodie et al., 2010).

In coastal waters, temporal variation in suspended sediment concentration occurs naturally due to seasonal and oceanographic processes (i.e. waves, changes in river effluents, storms, upwelling currents, tides; Larcombe et al., 1995; Wolanski et al., 2005; Storlazzi et al., 2009). There is also evidence, however, of human-induced sedimentation effects. There has been a global increase, over the past century, in the volume of sediment moving from land-based sources into coastal ecosystems (Lohrer et al., 2006; Bannister et al., 2012; Stender et al., 2014; Capuzzo et al., 2015) as a result of changes in land use, such as deforestation and farming practices. In addition to terrestrially derived sediment inputs, human activities in the ocean, such as dredging, coastal fisheries, and seabed mining can also increase the concentration of sediment in the water column (Fettweis et al., 2010). Dredging activities have led to the displacement of millions of cubic metres of sediment around the world's coastline over recent decades (Hanley, 2011; McCook et al., 2015).

Sediment input into marine ecosystems results firstly in an increase in water turbidity, which then reduces light availability and irradiance reaching the benthos (Kirk, 1985; Davies-Colley \& Smith, 2001). Turbidity and the subsequent reduced visibility can also compromise predators, such as fish and seabirds, in targeting their prey (Mallela et al., 2007). Furthermore, suspended particles can carry nutrients, trace metals and organic carbon, hence any elevated sediment levels may alter food chains and food availability for suspension feeders. Suspended particles can also act as vectors for pathogens, pesticides, and organic chemicals, such as polycyclic aromatic hydrocarbons (PAHs) and polychlorinated biphenyls (PCBs) (McCook et al., 2015; Schoellhamer et al., 2007). 
Deterioration of water quality can influence the abundance, diversity and structure of benthic marine communities (Fabricius, 2005; Knapp et al., 2013). In fact, among marine communities, it is the benthic biota that are the most susceptible to such environmental disturbance as they are often sessile or show low mobility, hence they cannot move to more favourable environments (Gray et al., 1990).

Other human-derived effects of elevated sediment that can affect benthic fauna include the loss of biodiversity, burial, or even total loss of the community and subsequent colonization by pioneer species (Thrush et al., 1995; Miller et al., 2002; Pawar 2013; Liu et al., 2015). For example, in the Mediterranean, Fraschetti et al. (2011) reported a loss of $<50 \%$ of seagrass meadows (Posidonia oceanica), a decline in macroalgal cover (Cystoseira spp.) and a loss in associated faunal assemblages, all driven by human-induced changes in sedimentation.

The effects of elevated suspended sediment concentrations (SSCs) have been well-documented for tropical marine benthic communities (Rogers, 1990; Fabricius, 2005; Jones et al., 2016). Firstly, light reduction associated with increased SSC is likely to have a strong effect on communities with phototrophic organisms. The turbidity associated with high SSCs in the water column can attenuate light for photosynthesis by autotrophic taxa, and subsequent light limitation can reduce energy for growth in seagrasses and scleractinian corals (Anthony \& Hoegh-Guldberg, 2003; Fabricius, 2005; Collier et al., 2012; Jones et al., 2016). Shading can also affect phototrophic sponges, causing a shift in their microbial composition, and lead to the loss of photopigments (bleaching), with implications for their physiology and survival (e.g., Cebrian et al., 2011).

Several authors have shown that the finer fractions of suspended solids can clog the feeding and respiratory apparatus of filter feeders such as sponges, ascidians, bivalves, and barnacles (Armsworthy et al., 2001; Ellis et al., 2002; Lohrer et al., 2006; Tompkins-MacDonald \& Leys, 2008). Suspended sediments can also negatively influence the reproductive output and life cycle stages of sessile benthic invertebrates, such as scleractinian corals and sponges (Whalan et al., 2007; Ricardo et al., 2016).

When falling out of suspension, sediment deposition can smother and, in extreme cases, bury benthic organisms. Trannum et al. (2010) reported that sedimentation events following dredging activities resulted in a reduction in the number of taxa, abundance and diversity of benthic macrofauna. Various studies have documented that when sediment settles on surfaces of suspension feeders, such as sponges (see Bannister et al., 2012; Biggerstaff et al., 2017; 
McGrath et al., 2017), ascidians, sea anemones (Armsworthy et al., 2001; Airoldi 2003) and corals (see review by Erftemejer et al., 2012), mucus is secreted as a clearing mechanism, which is likely to be energetically expensive and produced at the expense of other processes, such as growth and reproduction. Deposition of fine sediments has also been shown to inhibit recruitment and development of larvae of corals and sponges and reduce juvenile survival (Fabricius 2005; Wahab et al., 2019).

\subsection{Sediment impacts in the deep sea}

While coastal ecosystems are generally the most exposed to the various negative impacts of sediment, both natural and human-induced, in offshore deep-sea regions bottom trawl fishing activities can also cause substantial impacts (Clark et al. 2016). Bottom trawl fishing gear can have significant environmental effects on benthic communities both directly (i.e., when retaining by-catch of invertebrates caught in the trawl or by direct physical damage caused by the heavy gear itself), and indirectly (i.e., by burial and smothering of fauna) (Hall-Spencer et al. 2002). Bottom trawl fishing gear disturbs several centimetres of the seafloor re-suspending large quantities of bottom sediment into the water column (Schoellhamer 1996; Durrieu de Madron et al., 2005; Bradshaw et al., 2012). It has been shown that concentrations of total suspended solids (TSS) after a single trawl pass can vary between 5 and $500 \mathrm{mg}^{-1}$ (Durrieu de Madron et al. 2005, Bradshaw et al. 2012). While the largest sediment particles settle within minutes or hours due to gravity, the finer mud particles $(<10 \mu \mathrm{m})$ can remain in suspension in the water column from weeks to months (Lepland \& Mortensen, 2008). Intense fishing practises can therefore contribute substantially to sediment resuspension and sediment transport in areas where natural sediment suspension has little or no impact, especially in deep water systems (Ferré et al. 2008).

Other human activities in offshore deep-sea regions, such as those associated with oil and gas exploration, drilling operations, cable laying, and especially exploration for deep-sea minerals as a future resource for mining have been on the increase in recent decades (Glover \& Smith, 2003; Ramirez-Llodra et al., 2015). The direct impacts of these activities, involving the direct physical removal of substrate and associated fauna, have the potential to cause sediment plumes and deposits (e.g., Boschen et al. 2016; Levin et al., 2016). Increased exploitation of the deep seafloor by potential deep-sea mining could lead to severe and long-lasting effects on the 
associated benthic communities (Miller et al., 2002; Gollner et al., 2017, Miller et al., 2018). Currently we know very little about these effects on deep-sea fauna.

\subsection{Sponges}

Sponges (Phylum Porifera) are the most ancient and simple metazoans living in our oceans (Müller, 2003) and an important benthic group found globally in both shallow and deep-sea waters. The Phylum is classified into four Classes: Calcarea, Hexactinellida, Homoscleromorpha and Desmospongiae. Demospongiae is the largest Class comprising 83\% of all known species (Van Soest et al., 2012). Sponges possess a very simple body structure that lack any true tissues or organs. They are made up of a collection of highly specialized cells that are responsible for all physiological processes (Ereskovsky et al., 2013). Sponges are generally composed of three layers of cells: the pinacoderm (external layer), the choanoderm (internal layer) and the mesohyl or mesenchyme (middle layer) (Figure 1.1). The mesohyl contains collagenous material and a network of spicules in which nutrient transfer, metabolic activity, reproduction and cellular communication occur (Simpson, 2012). For some species, the mesohyl also hosts dense microbial communities that are composed of numerous species of bacteria, fungi, microalgae and archaea (Taylor et al., 2007) and can account for up to $35 \%$ of a sponge's biomass (Vacelet \& Donadey, 1977). 


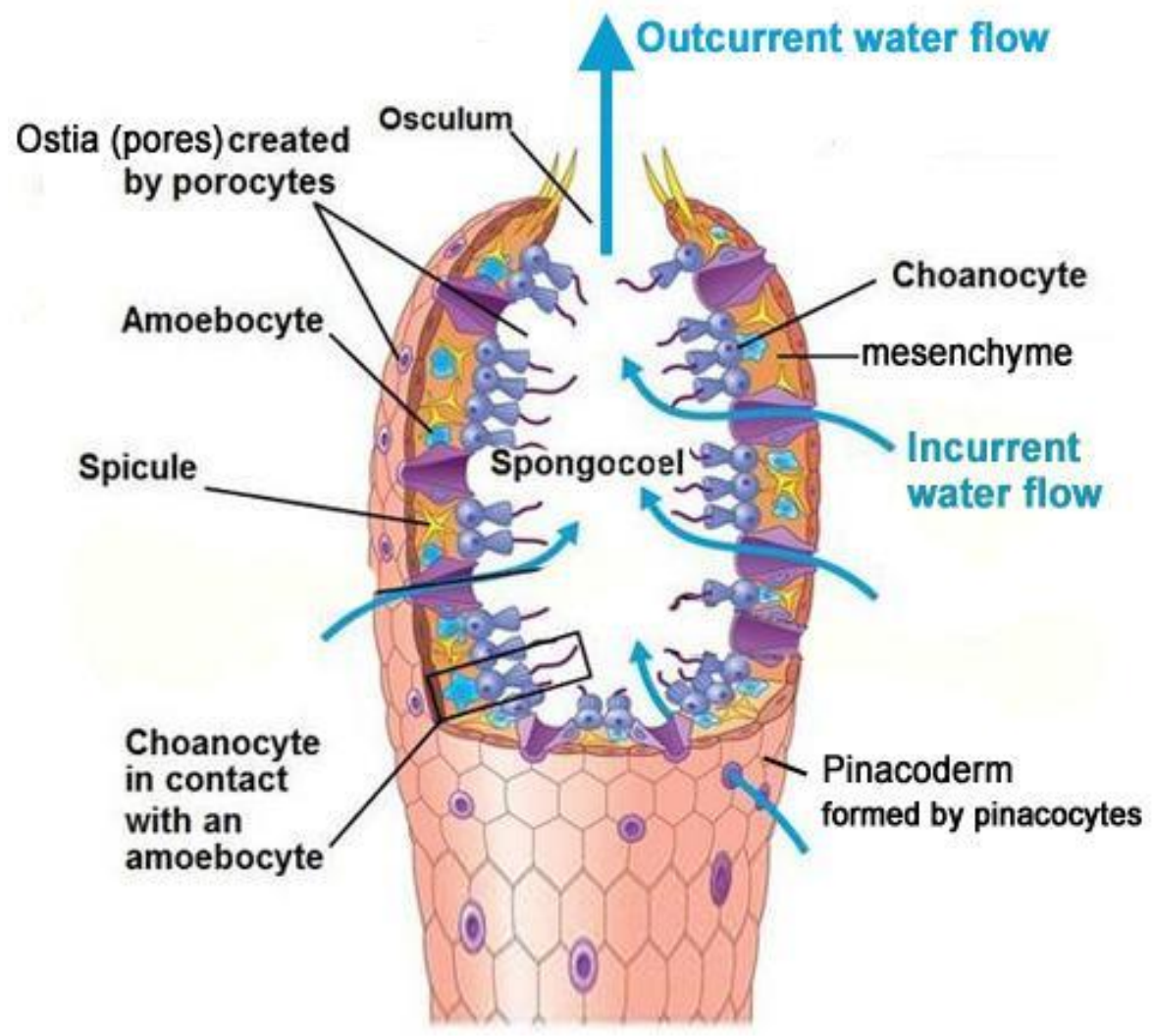

Figure 1.1. Schematic representation of sponge body plan and water pumping mechanism (Campbell \& Reese, 2002).

The sponge body plan has evolved for filter feeding. Water enters the sponge through surface pores called ostia and is expelled through larger apertures called oscula. Water is pumped in through inhalant canals to choanocyte chambers that possess flagellated choanocytes that pump water through a collar filter that retains suspended particles (Riisgård \& Larsen 1995). Some species can filter up to 72,000 times their body volume per day and can retain particles with an extremely high efficiency (>90\%) (Reiswig 1971; Pile et al., 1997; Koopmans et al., 2010). Sponges feed principally on dissolved organic carbon (DOC), picoplankton and bacteria present in the water column (Reiswig 1971, Riisgård et al., 1995). Some species can be phototrophic (i.e. they contain phototrophic symbionts that provide the carbon nutrition to their host) (Cheshire and Wilkinson, 1991). Water flow within the sponge body also brings in oxygen for respiration and contributes to waste removal from their internal canals.

Sponges possess very specialized cells, called archaeocytes, which provide them with the ability to heal rapidly after minor damage (Müller et al., 1999). Their simple physiological functioning and their ability to adapt to multiple external disturbances have made sponges one of the most historically persistent phyla in the marine environment (Zhang \& Pratt, 1994). 


\subsubsection{Ecological importance of sponges}

Sponges are important components of the benthic fauna and contribute in a variety of ways to ecosystem functioning, including substrate consolidation, habitat provision, bentho-pelagic energy transfer and seawater filtration (Reiswig 1971, 1974; Ribeiro et al., 2003; Pile and Young, 2006). They provide habitats for diverse macroinvertebrate groups, such as polychaetes and crustaceans (Bacescu, 1971; Wendt et al., 1985). Sponges are also considered to be effective spatial competitors (Wulff, 2006; Taylor et al., 2007). Furthermore, they have an important bioeroding role on coral reefs where they contribute to the breakdown of dead coral skeletons and other calcium carbonate structures into sediments, whereby some of the carbonate is dissolved in the process (Pomponi, 1977; Calcinai et al., 2007). Sponge assemblages are regulated by both top-down (e.g. predation, see Pawlik et al., 2013) and bottom-up (e.g. food supply, Lesser \& Slattery, 2013) processes. Their extremely effective particle retention and water filtration efficiency make sponges important nutrient links between water column productivity and the benthic community (Pile et al., 1997; Lesser 2006).

Sponges have been shown to take part in organic matter and nutrient cycling (Jimenéz \& Ribes 2007; Fiore et al., 2013; Mueller at al., 2014; Cathalot et al., 2015), and contribute to benthicpelagic coupling of particulate carbon at a range of scales (Reiswig, 1971; Gili \& Coma, 1998; Ribes et al., 1999). The contribution of sponge-mediated carbon exchange between the benthos and the water column has been observed to extend to the DOC pool. de Goeij et al. (2013) showed that sponges also perform an important functional role analogous to that of the microbial loop, whereby DOC is assimilated and made available to higher trophic levels in the form of detritus. Rix et al. $(2016 ; 2017)$ showed that sponges can consume algal and coralderived DOC in both tropical and temperate environments. More recently, McMurray et al. (2018) suggested that instead of releasing assimilated carbon in the form of detritus as originally proposed for cryptic sponges, emergent sponge species are likely to retain assimilated carbon as biomass. These authors proposed an additional pathway by which the sponge-loop fuels higher trophic levels via predation by fish, turtle, and invertebrate spongivores. However, although the sponge loop represents a potentially important functional role it remains controversial (McMurray et al., 2018). 


\subsubsection{Sponges in shallow-water reefs}

Sponges are a very diverse phylum and can be the dominant fauna in many environments, including shallow tropical and temperate reef habitats, where they can be found in high densities (Wilkinson \& Evans, 1989; Bell \& Barnes, 2000; Murillo et al., 2012; Maldonado et al., 2017). Some shallow water sponges host phototropic symbionts both in tropical and temperate reefs (Lemloh et al., 2009). In temperate regions, where sponges are important members of rocky communities, they are considered one of the top spatial competitors (Bell \& Barnes, 2003).

Reductions in the abundance, biomass, and species richness of sponges can result in cascading impacts on marine ecosystems (Peterson et al., 2006; Bell 2008). For example, Peterson et al. (2006) described how persistent phytoplankton blooms in the Florida Bay, United States, are due to the large-scale mortality of sponge assemblages. By estimating particle removal rates and pumping rates these authors found that the historical sponge populations in Florida Bay had the potential to control the phytoplankton blooms.

\subsubsection{Sponges in deep-water reefs}

Sponges dominate some deep-sea (lower shelf, bathyal and/or abyssal depths) benthic areas where they constitute important biodiversity hotspots along with corals (Longo et al., 2005; Cathalot et al., 2015; Kahn et al., 2015). Deep-sea coral and sponge aggregations can form extensive reef-like structures (Roberts et al., 2009; Tracey et al., 2011). These habitats have been classified as vulnerable marine ecosystems (VMEs) by the United Nations General Assembly (UNGA) Resolution 61/105 (FAO, 2009). VMEs are defined as ecosystems that are both easily disturbed and are very slow to recover or that may never recover (FAO, 2008). These fragile habitats are considered to be particularly vulnerable to ongoing (fisheries, oil and gas exploitation) and emerging (mining) industries acting on the deep-sea floor (Xavier et al., 2015). Deep-sea sponges are considered essential habitat-forming components of deep-water ecosystems and thereby need to be managed and preserved (Campbell \& Simms, 2009; NOAA, 2010).

Deep-sea sponges provide key ecosystem services. They constitute biodiversity hotspots, where they can comprise up to $90 \%$ of the benthic biomass (Klitgaard \& Tendal 2004; Murillo et al., 2012). These extremely high biomasses are responsible for significant nitrogen, carbon and silica cycling processes (Pile \& Young, 2006; Chu et al., 2011). Some glass reef sponges 
have been found to filter almost continuously (Kahn et al., 2015). Through their filtration, they clear a large quantity of bacteria in the water column above them, and also recycle wastes to the water in the form of ammonium and $\mathrm{CO}_{2}$ (Kahn et al., 2015). Deep-sea sponges have also been found to have associations with methanotrophic bacteria surrounding hydrothermal vents and cold seeps (Vacelet et al., 1995; 1996). These associations often dominate deep-sea communities that depend on chemosynthesis, resulting in locally high densities of invertebrates, which may suggest an important productivity role of the sponges in methanerich environments (Rubim-Blum et al., 2019).

Bioerosion is another role played by deep-sea sponges. In the Mediterranean, Beuck et al. (2007) reported several species of bioeroding sponge associated with deep water Lophelia pertusa reefs, which are thought to influence the structural integrity of the coral. Deep-sea sponges and coral gardens can be easily damaged by fishing activities, mineral resource exploration and extraction and energy exploration and production (NOAA, 2010).

\subsubsection{Sediment impacts on sponges}

Sponges show a variety of adaptations to sediment exposure (Ilan \& Abelson 1995; Cerrano et al., 2007; Schönberg 2016). Some sponge species are found and even thrive in highly sedimented areas (Bell \& Barnes 2000; Bell \& Smith 2004). Psammobiotic sponges, for example, are named as such for their ability to actively incorporate sediment as a strategy to augment or replace specular skeletons, reducing energy expenses for spiculogenesis (Scönberg 2016). In other studies, however, natural turbidity gradients have been found to affect sponge distributions, with more phototrophic sponges found in offshore waters where SSCs are lower (e.g. Wilkinson \& Cheshire 1989, Bannister et al. 2010). Although it has been estimated that $10 \%$ of all studied sponges are well adapted to elevated sediment levels, there is evidence that sediment can be deleterious to many sponge species at individual and population levels (Bell et al., 2015). Direct and indirect impacts of sediment on sponges have been reviewed by Bell et al. (2015) and Schönberg (2016), but still little is known about the specific responses of most sponge species.

When exposed to elevated concentrations of suspended sediment, sponges can filter fine particles into their aquiferous system and choanocyte chambers (Tompkins-MacDonald \& Leys, 2008). The effects of suspended sediments on sponges include reductions in sponge pumping activity (Lohrer et al., 2006; Tompkins-MacDonald and Leys, 2008), which can 
impede feeding efficiency (Lohrer et al., 2006), alter respiration rates (Bannister et al., 2012; Tjensvoll et al., 2013; Kutti et al., 2015; Pineda et al., 2017) and cause tissue abrasion (Nava \& Carballo, 2013), resulting in partial mortality and reduced survival.

Respiration rates in sponges exposed to suspended sediment have shown contrasting alterations: they have been shown to both increase (Bannister et al., 2012; McGrath et al., 2017) and decrease (Lohrer et al., 2006; Tjensvoll et al., 2013; Kutti et al., 2015; Pineda et al., 2017, Scanes et al., 2018). Increased respiration rates may reflect the energetic costs of sediment clearance mechanisms, such as mucus production following short-term exposure, whereas respiration rates may decrease due to a reduction in pumping rate to prevent sediment intake (Bell et al., 2015). The level of the stress response has been related to sediment size, mineralogy and concentration. Bannister et al. (2012) found that the respiration rates of the tropical sponge Rhopaloeides odorable increased by $35 \%$ when exposed to fine clay sediment, whereas they increased by just $12 \%$ when exposed to the same concentration of carbonate sediment.

Indirect impacts of increased sediment levels include reduced growth, survival and reproduction rates of sponges (Roberts et al., 2006a; Whalan et al., 2007; Maldonado et al., 2008). Roberts et al. (2006a) and Abdo et al. (2006) found that increased sedimentation and turbidity resulted in significant weight loss of two temperate phototrophic sponges. Whalan et al. (2007) reported a higher proportion of reproducing Rhophaloides odorabile in populations offshore compared to populations from coastal reefs exposed to more turbid waters. These authors suggested that reproductive success was lowered in turbid environments as a result of reduced pumping activity and therefore food consumed, hence less energy was available for reproduction. Maldonado et al. (2008) and Wahab et al. (2019) found that juvenile stages of sponges exposed to sediment had higher mortality than those not exposed.

With respect to deep-sea sponges, there are very few studies that have investigated the impacts of sediment (see Tjensvoll et al. 2013; Kutti et al. 2015, Scanes et al., 2018). Tjensvoll et al. (2013) reported an $86 \%$ reduction in respiration rates of the sponge Geodia barretti when exposed to short-pulse sediment concentrations of $100 \mathrm{mg}^{-1}$. Kutti et al. (2015) reported a $50 \%$ reduction in respiration rates of sponges exposed to short-term sediment concentrations of $500 \mathrm{mg} \mathrm{l}^{-1}$ and a permanent drop in oxygen consumption in $60 \%$ of sponges exposed to long-term (50 days) cyclic exposure to sediment concentration of $50 \mathrm{mg}^{-1}$. Scanes et al. (2018) reported a $50 \%$ reduction in respiration rates of $G$. atlantica sponges exposed to $10 \mathrm{mg} \mathrm{l}^{-1}$ SSCs for 40 days. Grant et al. $(2018$; 2019) reported in situ temporary pumping arrest in deep- 
sea sponges exposed to $10-80 \mathrm{mg}^{-1} \mathrm{SSCs}$. These results suggest that the sponges could be significantly impacted by increased sediment concentrations that could result in the loss of ecosystem services provided by sponges.

\subsection{Scleractinian corals}

Corals are a diverse and important benthic group belonging to the Phylum Cnidaria, Classes Anthozoa and Hydrozoa. Some corals are solitary, while numerous species of the Order Scleractinia (Class: Anthozoa, Subclass: Hexacorallia) can build large reefs in both shallow and deep-sea waters (Rogers et al., 1999; Roberts et al., 2004). Scleractinian corals differ from the other members of the Class Anthozoa because they bear a calcareous exoskeleton and are also called 'stony' corals.

Scleractinian corals cells are organized in three tissue layers: the epidermis, mesoglea and gastrodermis (Figure 1.2). The epidermis contains cnidae, mucocytes, pigment cells, calicoblastic cells, epitheliomuscular cells and other supporting cells. The calicoblastic cells are responsible for the production of the skeleton. The mesoglea is a connective tissue layer that can be bordered by the epidermis and gastrodermis, or by gastrodermis on both sides. The gastrodermis covers the digestive lumen and, in shallow-water symbiotic corals, it contains the symbiotic algae: the zooxanthellae. Both the epidermis and gastrodermis contain neurons and epitheliomuscular cells (Galloway et al., 2007)

Colonial scleractinian corals are composed of several polyps that are interconnected through the coenenchyme (or coenosarc) tissue. The oral end of each polyp is surrounded by a ring of tentacles, which serve for capturing food particles. Below the mouth there is an invagination of the epidermis that forms a muscular tubular passage to the gastric cavity: the actinopharynx (Fautin \& Mariscal, 1991). The gastric cavity contains the mesenteries, internal longitudinal partitions that provide structural support and increase the surface area of the gastrodermis to improve nutrient absorption (Galloway et al., 2007). Gonads develop in the gastrodermis. 


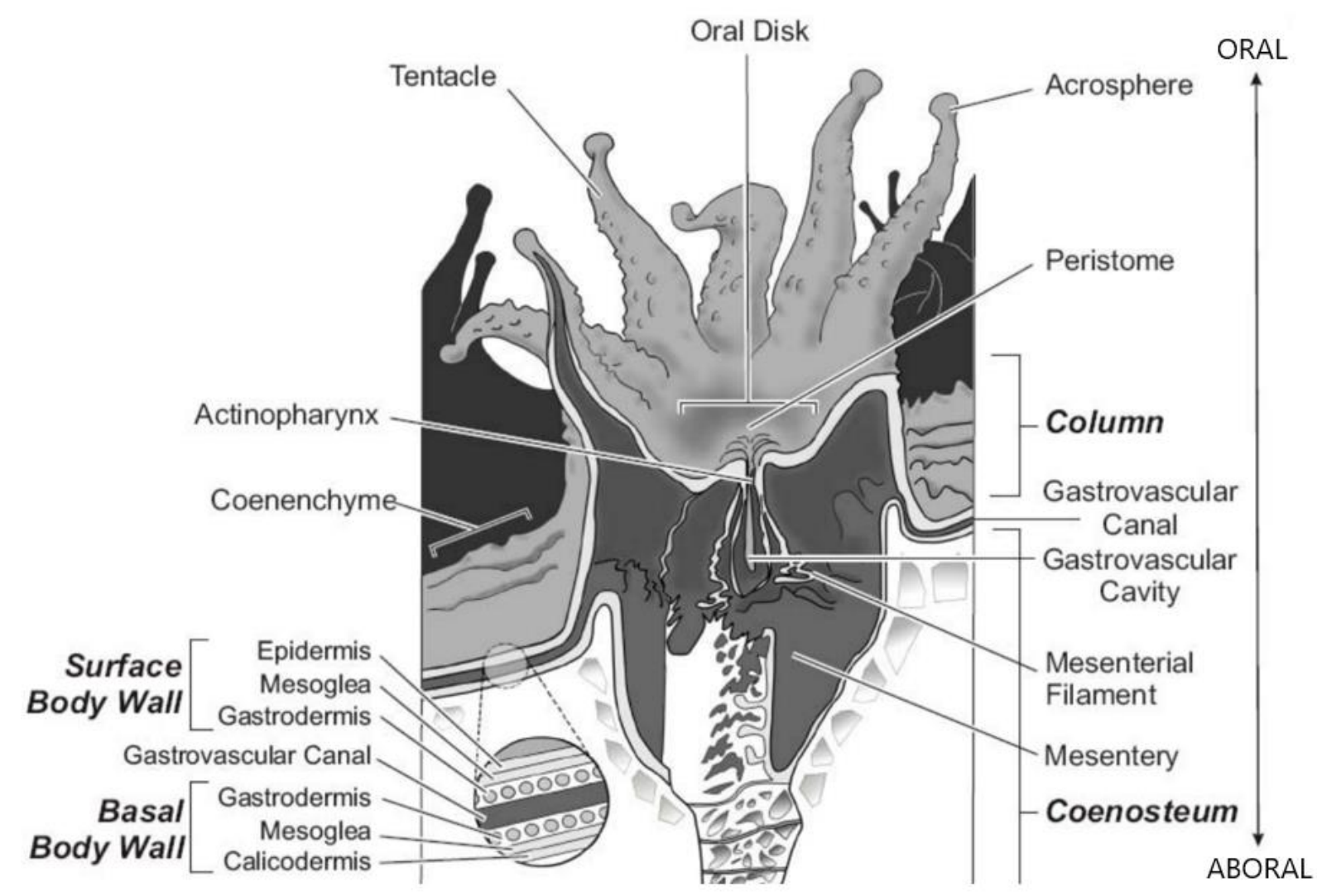

Figure1.2. Anatomy of a scleractinian coral polyp. Picture taken from Galloway et al., (2007).

\subsubsection{Deep-sea scleractinian corals}

Deep-sea corals (Phylum: Cnidaria, Classes: Anthozoa, Hydrozoa), also known as cold-water corals, are key components of some deep-sea benthic ecosystems (Roberts \& Hirshfield, 2004). Deep-sea corals are restricted to temperatures between 4 and $12{ }^{\circ} \mathrm{C}$ and are most commonly found between 200 and 2000 m depth (Freiwald et al., 2004; Roberts et al., 2006b). Deep-sea corals include stony corals (Scleractinia), soft corals (Octocorallia), black corals (Antipatharia) and hydrocorals (Stylasteridae) (Roberts et al., 2006b). Unlike most of the tropical shallowwater corals, deep-sea corals lack any symbiotic association with microalgae.

As for shallow-water corals, some deep-sea scleractinian corals can build large reefs (Rogers et al., 1999; Roberts et al., 2004). Deep-sea coral reefs can extend for several kilometres and reach many meters from the seafloor, creating the most complex habitats in the deep-sea (Freiwald, 2002; Roberts et al., 2006b). These reefs provide important habitats for fish and invertebrates: they provide protection from currents and predators, feeding, breeding and spawning areas for numerous fish, and nurseries for juveniles (Husebo, 2002; Fossa et al., 2002, Henry et al., 2013). Thus, they support high abundance and diversity (Etnoyer \& Morgan, 2005; 
Buhl-Mortensen \& Mortensen, 2004, Roberts et al., 2004: Roberts et al., 2006b). For example, in the northeast Atlantic, over 1300 species have been recorded living on Lophelia pertusa reefs (Roberts et al., 2006b). In addition, several economically valuable fish are supported by deep-sea reefs (Roberts et al., 2009). Deep-sea coral ecosystems also contribute to carbon cycling (van Oevelen et al., 2009; White et al., 2012).

Deep-sea corals are generally slow growing, long lived and fragile, characteristics that make them extremely vulnerable to anthropogenic-induced seafloor disturbances (fisheries, oil and gas exploitation and potential deep-sea mining; Roberts et al., 2009, Clark et al., 2010; Clark et al., 2016). Some deep-sea coral reefs are thought to be many thousands of years old (Rogers et al., 1999). Because of their vulnerability and importance to/in deep-sea ecosystems, deepsea coral habitats have been classified as Vulnerable Marine Ecosystems (VMEs) by the United Nations General Assembly (UNGA) Resolution 61/105 (FAO, 2009), and it is widely thought that they should be subject to conservation actions.

Bottom trawling is considered the most damaging anthropogenic activity to deep-sea coral and sponge assemblages (Ragnarsson et al., 2017). Destruction of deep-sea coral reefs by bottomtrawling activities has been well documented in Norway (Armstrong \& van den Hove, 2008), Florida (Koenig et al., 2005; Reed et al., 2007) and Ireland (Foley et al., 2011). In Norway, between one-third and one-half of the deep-sea coral reefs have been destroyed by bottom trawling activities targeting redfish (Fossa et al., 2002). In Florida, between 90 and $99 \%$ of Oculina varicosa reefs have been destroyed (Koenig et al., 2005). In New Zealand, Clark \& Rowden (2009) found that coral coverage decreased significantly where fishing effort was high on small seamounts, and that dense colonies of scleractinian corals were found only on unfished seamounts where the seabed is too rough for bottom trawling (Clark \& Dunn, 2012). Similar reductions in coral cover on fished seamounts have been observed off Tasmania (Koslow et al., 2001; Williams et al., 2020). As large reefs can be thousands of years old (Rogers 1999), the recovery of deep-sea habitats that have suffered structural damage is very slow (Althaus et al., 2009; Williams et al., 2010; Clark et al., 2019; Goode et al., 2020).

In addition to direct physical impacts, offshore activities, in particular bottom trawling and potential deep-sea mining, have the potential to generate sediment plumes through the resuspension of seafloor sediment (e.g. Clark et al., 2016; Miller et al., 2018). The effects of suspended sediments and sediment deposition on deep-sea corals are largely unknown. 


\subsubsection{Sediment impacts in deep-sea scleractinian corals}

While the effects of sediments on shallow-water corals have been subject of several studies (reviewed Erftemeijer et al., 2012), knowledge of these effects on deep-sea corals is very limited. It is thought that deep-sea corals might be more sensitive to sediments than those in shallow-water as they are not exposed to natural sediment resuspension caused by storms, as happens in shallow-waters (Ragnarsson et al., 2017).

Investigations on the effects of sediments on deep-sea stony corals have been conducted on the only reef-building deep-sea species Lophelia pertusa (Brooke et al., 2009; Larsson \& Purser, 2011; Larsson et al., 2013; Allers et al., 2013). Experimental studies demonstrated that adult L. pertusa fragments showed tolerance to $\sim 50 \mathrm{mg} \mathrm{l}^{-1} \mathrm{SSC}$ for a two-week period exposure ( 90 $\%$ survival), but mortality increased at higher SSCs, with $50 \%$ mortality at $100 \mathrm{mg} \mathrm{l}^{-1} \mathrm{SSCs}$ and $>90 \%$ mortality at $\sim 360 \mathrm{mg}^{-1}$ SSC (Brooke et al., 2009). Burial experiments have shown that L. pertusa can sustain 24 h of total burial (almost $100 \%$ survival), but almost all corals die between 2 and 4 days after burial (Brooke et al., 2009). Sublethal effects of natural sediments and drill cuttings on adult L. pertusa fragments included partial polyp and tissue mortality (6.5and 19-mm burial from drill cuttings; Larsson and Purser, 2011), whereas respiration rates and sediment clearing ability were not affected (Larsson and Purser, 2011; Larsson et al., 2013). There is some evidence that larvae are more susceptible than adults to the effects of high SSCs: exposure of $L$. pertusa larvae to drill cuttings ( 0.5 to $640 \mathrm{ppm})$ for $24 \mathrm{~h}$ caused significant larval mortality due to clogging of larval cilia, preventing the larvae from swimming (Järnegren et al., 2017).

\subsection{New Zealand region (study site)}

Sponges and corals are important fauna of New Zealand waters. Sponges occur across New Zealand, from intertidal areas out to the deep sea with many species of wide-ranging size, form and colour. Sponges have been reported as the largest contributors to total biomass in many parts of the New Zealand shallow-water regions (Shears et al., 2007). Typical habitats that support high sponge abundance are rocky subtidal reefs (Kelly et al., 2009; Berman \& Bell, 2010). To date, few studies have addressed the impacts of increased sediment levels on New Zealand sponges (but see Lohrer et al., 2006; Schwartz et al., 2006; Murray, 2009). Lohrer et al. (2006) reported reduced condition, clearance rates and respiration rates in sponges (Aaptos sp.) exposed to terrigenous sediment deposition. Murray (2009) reported decreased metabolic 
activity in one sponge species exposed to three days of heavy suspended sediment loads. However, the impact of sediment on most sponge species and the threshold sediment levels that sponges can resist when exposed to chronic stress is mostly unknown.

Scleractinian corals are widespread in New Zealand deep-sea waters, with over 100 species being reported, representing $16.4 \%$ of the global scleractinian coral species (Tracey et al., 2011; Tracey et al., 2019). Of these, $74 \%$ are solitary corals and $26 \%$ are framework-building species (Cairns 2007). Bottom-contact fishing activities in the deep-sea surrounding New Zealand have affected coral presence and abundance (Clark et al., 2010). However, to date the effects of elevated suspended sediments that can arise from bottom-trawling and potentially deep-sea mining, have not been investigated in New Zealand deep-sea corals.

Elevated sediment loads in New Zealand coastal waters and resuspension of bottom sediment caused by storms are considered major threats to coastal biodiversity (Ministry for the Environment, 2015; Cussioli et al., 2019; Siciliano et al., 2019). In addition, offshore bottomcontact fishing activities and future deep-sea mining in New Zealand may re-suspend sediment in the water column with effects on the associated fauna. In order to assess the response of temperate shallow and deep-sea water sponges to elevated sediment concentrations, two study sites have been chosen in New Zealand, one a coastal site and the second, a deep-sea site east of New Zealand.

\subsubsection{Shallow-water site}

The south coast of Wellington is an energetic environment whose tidal and oceanic flows are influenced by Cook Strait weather (Carter 2008); water temperatures range between $11{ }^{\circ} \mathrm{C}$ in winter to $16^{\circ} \mathrm{C}$ in summer (Berman \& Bell 2010). This dynamic marine environment supports high sponge abundance and diversity on boulders and overhangs in the rocky subtidal ecosystems that characterise this coast (Berman et al., 2008).

\subsubsection{Deep-water site}

The Chatham Rise is a submarine continental ridge extending about $1500 \mathrm{~km}$ eastwards from New Zealand into the Southwest Pacific Ocean. The rise is delineated by the $2000 \mathrm{~m}$ isobath, and its crest is approximately $130 \mathrm{~km}$ wide and lies at 350-400 m depth (Mackay et al., 2005). Water temperatures range between $\sim 4{ }^{\circ} \mathrm{C}$ at depth and $11-14{ }^{\circ} \mathrm{C}$ at the surface and there is 
evidence of warming in this region (Pinkerton, 2017). The Chatham Rise forms one of the three major bathyal areas comprising the extension of the New Zealand offshore region. The Chatham Rise is a nursery ground for hoki, New Zealand's largest commercial fishery that yields about one-third of the deep-water fishery of the New Zealand Exclusive Economic Zone (EEZ) and plays an important role in the deep-sea fishery economy of New Zealand (MPI, 2017). The top of the Chatham Rise is where a mining project for phosphate nodules has been proposed (NZ EPA, 2015). This activity could lead to significant negative impacts on associated benthic organisms, in particular on suspension feeders like sponges and corals.

\subsection{Aims}

The overall aim of this thesis is to measure the effects of elevated concentrations of suspended sediments on shallow and deep-sea sponges, and on a deep-sea coral, and provide a more comprehensive understanding of dose-response effects on these taxa. In a series of experiments, carried out at the National Institute of Marine and Atmospheric Research (NIWA), I exposed New Zealand sponges (shallow and deep-sea) and a deep-sea coral species to controlled suspended sediment concentrations relevant to those likely from bottom-trawling and potential deep-sea mining. The outcome of this thesis will help evaluate the effects of activities such as fisheries and deep-sea mining on vulnerable benthic taxa, and it can contribute to the development of management options around these activities to minimize their impacts.

The first data chapter explores survival and physiological responses of the common New Zealand shallow-water sponge Crella incrustans to elevated suspended sediment concentrations (SSCs) and its recovery ability. I exposed $C$. incrustans to a range of SSCs up to $\sim 800 \mathrm{mg}^{-1}$ in the attempt to find a threshold level above which sponge functioning would be compromised. Survival and physiological responses were measured, as well as morphological modifications.

The second data chapter explores the responses of the common New Zealand deep-sea sponge Ecionemia novaezealandiae to selected SSC levels relevant to bottom trawling activities and potential deep-sea mining. I explored survival and sublethal effects that included respiration rates and necrosis.

The third data chapter explores the responses of the habitat-forming New Zealand deep-sea coral Goniocorella dumosa to cycles of selected SSC levels relevant to bottom trawling 
activities and potential deep-sea mining. I assessed survival, physiological responses, and sublethal effects (polyp and partial tissue mortality).

The fourth data chapter explores whether G. dumosa ingests sediment particles. Furthermore, using histology techniques, I investigated whether exposure to high suspended sediment concentrations causes structural damage to G. dumosa. 


\section{References}

Abdo, D.A., Battershill, C.N., Harvey, E.S. (2006). Manipulation of environmental variables and the effect on the growth of Haliclona sp.: implications for open-water aquaculture. Marine Biology Research, 2, 326-332.

Airoldi, L. (2003). The effects of sedimentation on rocky coast assemblages. Oceanography and Marine Biology, an Annual Review, 41,161-236.

Airoldi, L., \& Beck, M.W. (2007). Loss, status and trends for coastal marine habitats of Europe. Oceanography and Marine Biology: An Annual Review, 45, 345-405.

Allers, E., Abed, R.M., Wehrmann, L.M., Wang, T., Larsson, A.I., Purser, A., de Beer, D. (2013). Resistance of Lophelia pertusa to coverage by sediment and petroleum drill cuttings. Marine Pollution Bulletin, 74, 132-140.

Althaus, F., Williams, A., Schlacher, T., Kloser, R., Green, M., Barker, B., Bax, N., Brodie, P., Schlacher-Hoenlinger, M. (2009). Impacts of bottom trawling on deep-coral ecosystems of seamounts are long-lasting. Marine Ecology Progress Series, 397, 279-294.

Anthony, K.R., \& Hoegh-Guldberg, O. (2003). Kinetics of photoacclimation in corals. Oecologia, 134, 23-31.

Armstrong, C.W., \& van den Hove, S. (2008). The formation of policy for protection of coldwater coral off the coast of Norway. Marine Policy, 32, 66-73.

Armsworthy, S.L., MacDonald, B.A., Ward, J.E. (2001). Feeding activity, absorption efficiency and suspension feeding processes in the ascidian, Halocynthia pyriformis (Stolidobranchia: Ascidiacea): responses to variations in diet quantity and quality. Journal of Experimental Marine Biology and Ecology, 260, 41-69.

Bacescu, M. (1971). Les Spongiaires; un des plus intéressants biotopes benthiques marins. Rapport et procésverbaux des reunions. Conseil permanent international pour l'exploration scientifique de la Mer Méditerrané, 20, 239-241.

Ball, B., Munday, B., Tuck, I. (2000). Effects of otter trawling on the benthos and environment in muddy sediments. In: Kaiser MJ, de Groot SJ (eds). Effects of fishing on non-target species and habitats: biological, conservation and socioeconomic issues. Blackwell Science Ltd., Oxford, UK. pp 69-82. 
Bannister, R.J., Battershill, C.N., De Nys, R. (2010). Demographic variability and long-term change in a coral reef sponge along a cross-shelf gradient of the Great Barrier Reef. Marine and Freshwater Research, 61, 389-396.

Bannister, R.J., Battershill, C.N., \& De Nys, R. (2012). Suspended sediment grain size and mineralogy across the continental shelf of the Great Barrier Reef: Impacts on the physiology of a coral reef sponge. Continental Shelf Research, 32, 86-95.

Bell, J.J. (2008). The functional roles of marine sponges. Estuarine, Coastal and Shelf Science, 79, 341-353. doi:http://dx.doi.org/10.1016/j.ecss.2008.05.002

Bell, J.J., \& Barnes, D. K. (2000). The distribution and prevalence of sponges in relation to environmental gradients within a temperate sea lough: inclined cliff surfaces. Diversity and Distributions, 6, 305-323.

Bell, J.J., \& Barnes, D.K.A. (2003). The importance of competitor identity, morphology and ranking methodology to outcomes in interference competition between sponges. Marine Biology, 143, 415-426.

Bell, J.J., \& Smith, D. (2004). Ecology of sponge assemblages (Porifera) in the Wakatobi region, south-east Sulawesi, Indonesia: richness and abundance. Marine Biological Association of the United Kingdom. Journal of the Marine Biological Association of the United Kingdom, 84, 581.

Bell, J.J., McGrath, E., Biggerstaff, A., Bates, T., Bennett, H., Marlow, J., Shaffer, M. (2015). Sediment impacts on marine sponges. Marine Pollution Bulletin, 94, 5-13.

Berman, J., \& Bell, J.J. (2010). Spatial variability of sponge assemblages on the Wellington South Coast, New Zealand. Open Marine Biology Journal, 4, 12-25.

Berman, J., Perea-Blázquez, A., Kelly, M., Bell, J.J. (2008). Sponges of the Wellington south coast. Gardner, J. \& J. Bell (eds), The Taputeranga Marine Reserve. First Edition Ltd, Wellington.

Beuck, L., Vertino, A., Stepina, E., Karolczak, M., Pfannkuche, O. (2007). Skeletal response of Lophelia pertusa (Scleractinia) to bioeroding sponge infestation visualised with microcomputed tomography. Facies, 53, 157-176. 
Biggerstaff, A., Smith, D. J., Jompa, J., Bell, J.J. (2017). Metabolic responses of a phototrophic sponge to sedimentation supports transitions to sponge-dominated reefs. Scientific Reports, 7, 2725 .

Boschen, R.E., Rowden, A.A., Clark, M.R., Pallentin, A., Gardner, J.P. (2016). Seafloor massive sulfide deposits support unique megafaunal assemblages: implications for seabed mining and conservation. Marine Eenvironmental Research, 115, 78-88.

Bradshaw, C., Tjensvoll, I., Sköld, M., Allan, I.J., Molvaer, J., Magnusson, J., Naes, K., Nilsson, H.C. (2012) Bottom trawling resuspends sediment and releases bio - available contaminants in a polluted fjord. Environmental Pollution, 170, 232-241.

Brodie, J., Schroeder, T., Rohde, K., Faithful, J., Masters, B., Dekker, A., Brando, V., Maughan, M. (2010). Dispersal of suspended sediments and nutrients in the Great Barrier Reef lagoon during river discharge events: conclusions from satellite remote sensing and concurrent flood-plume sampling. Marine and Freshwater Research, 61, 651-664.

Brooke, S., Holmes, M., Young, C.M. (2009). Effects of sediment on two morphotypes of Lophelia pertusa from the Gulf of Mexico. Marine Ecology Progress Series, 390, 137-144.

Buhl-Mortensen, \& L., Mortensen, P.B. (2004). Symbiosis in deep-water corals. Symbiosis, $37,33-61$.

Cairns, S.D. (2007). Deep-water corals: an overview with special reference to diversity and distribution of deep-water scleractinian corals. Bulletin of Marine Sciences, 81, 311-322.

Calcinai, B., Azzini, F., Bavestrello, G., Gaggero, L., Cerrano, C. (2007). Excavating rates and boring pattern of Cliona albimarginata (Porifera: Clionaidae) in different substrata. Porifera Research: Biodiversity, Innovation \& Sustainability, Proceedings of the $7^{\text {th }}$ international Sponge Symposium, 255-263.

Campbell, J.S., \& Simms, J.M. (2009). Status Report on Coral and Sponge Conservation in Canada. DFO, St. John's, NL, Canada.

Campbell, N.A., \& Reese, J.B. (2002). Biology ( $6^{\text {th }}$ edition), Benjamin Cummings.

Capuzzo, E., Stephens, D., Silva, T., Barry, J., Forster, R.M. (2015). Decrease in water clarity of the southern and central North Sea during the 20th century. Global Change Biology. http://dx.doi.org/10.1111/gcb.12854. 
Carter, L. (2008), The Taputeranga Marine Reserve, 1 edn, First Edition Ltd, Wellington, chapter Below Low Tide- A Seabed in Motion, pp. 130-44.

Cathalot, C., Van Oevelen, D., Cox, T.J.S., Kutti, T., Lavaleye, M., Duineveld, G., Meysman, F.J.R. (2015). Cold-water coral reefs and adjacent sponge grounds: hotspots of benthic respiration and organic carbon cycling in the deep sea. Frontiers in Marine Science, 2. doi:10.3389/fmars.2015.00037

Cebrian, E., Uriz, M. J., Garrabou, J., Ballesteros, E. (2011). Sponge mass mortalities in a warming Mediterranean Sea: are cyanobacteria-harboring species worse off? PLoS One, 6, e20211.

Cerrano, C., Calcinai, B., Di Camillo, C.G., Valisano, L., Bavestrello, G. (2007). How and why do sponges incorporate foreign material? Strategies in Porifera. Porifera Research: Biodiversity, Innovation and Sustainability. Série Livros, 28, 239-246.

Chu, J.W., Maldonado, M., Yahel, G., Leys, S.P. (2011). Glass sponge reefs as a silicon sink. Marine Ecology Progress Series, 441, 1-14.

Clark, M.R., Bowden, D.A., Rowden, A.A., Stewart, R. (2019). Little Evidence of Benthic Community Resilience to Bottom Trawling on Seamounts After 15 Years. Frontiers in Marine Science, 6. 〈http://dx.doi.org/10.3389/fmars.2019.00063>

Clark, M.R., \& Dunn, M.R. (2012). Spatial management of deep-sea seamount fisheries: balancing sustainable exploitation and habitat conservation. Environmental Conservation, 39, 204-214. http://dx.doi.org/10.1017/s0376892912000021

Clark, M.R., \& Rowden, A.A. (2009). Effect of deep water trawling on the macro-invertebrate assemblages of seamounts on the Chatham Rise, New Zealand. Deep Sea Research I, 56, 15401554. 〈http://dx.doi.org/doi:10.1016/j.dsr.2009.04.015>

Clark, M.R., Rowden, A.A., Schlacher, T., Williams, A., Consalvey, M., Stocks, K.I., Rogers, A.D., O'Hara, T.D., White, M., Shank, T.M., Hall-Spencer, J.M. (2010). The ecology of seamounts: Structure, function, and human impacts. Annual Review of Marine Science, 2, 253278.

Clark, R.M., Althaus, F., Schlacher T.A, Williams, A., Bowden, D.A, Rowden, A.A. (2016). The impacts of deep-sea fisheries on benthic communities: a review, ICES Journal of Marine Science, Volume 73, 151-169, https://doi.org/10.1093/icesjms/fsv123. 
Collier, C.J., Waycott, M., Ospina, A.G., (2012). Responses of four Indo-West Pacific seagrass species to shading. Marine Pollution Bulletin. 65, 342-354.

Crain, C.M., Halpern, B.S., Beck, M.W., Kappel, C.V. (2009). Understanding and managing human threats to the coastal marine environment. Annals of the New York Academy of Sciences, 1162, 39-62.

Cussioli, M.C., Bryan, K.R., Pilditch, C.A., de Lange, W.P., Bischof, K. (2019). Light penetration in a temperate meso-tidal lagoon: implications for seagrass growth and dredging in Tauranga Harbour, New Zealand. Ocean Coastal Management, 174, 25-37.

Davies-Colley, R., \& Smith, D. (2001). Turbidity, suspended sediment, and water clarity: a review. Journal of the American Water Resources Association, 37, 1085-1101.

De Goeij, J.M., Van Oevelen, D., Vermeij, M.J., Osinga, R., Middelburg, J.J., de Goeij, A. F., Admiraal, W. (2013). Surviving in a marine desert: the sponge loop retains resources within coral reefs. Science, 342, 108-110.

Diaz, R.J., Rosenberg, R. (2008). Spreading dead zones and consequences for marine ecosystems. Science, 321, 926-929.

Durrieu de Madron, X., Ferré, B., Le Corre, G., Grenz, C., Buscail, R., Bodiot, O. (2005) Trawling-induced resuspension and dispersal of muddy sediments and dissolved elements in the Gulf of Lion (NW Mediterranean). Continental Shelf Research, 25, 2387-2409.

Ellis, J., Cummings, V., Hewitt, J., Thrush, S., Norkko, A. (2002). Determining effects of suspended sediment on condition of a suspension feeding bivalve (Atrina zelandica): results of a survey, a laboratory experiment and a field transplant experiment. Journal of Experimental Marine Biology and Ecology, 267, 147-174.

Ereskovsky, A.V., Renard, E., Borchiellini, C. (2013). Cellular and molecular processes leading to embryo formation in sponges: evidences for high conservation of processes throughout animal evolution. Development Genes and Eevolution, 223, 5-22.

Erftemeijer, P.L., Riegl, B., Hoeksema, B.W., Todd, P.A. (2012). Environmental impacts of dredging and other sediment disturbances on corals: a review. Marine Pollution Bulletin, 64, $1737-1765$.

Etnoyer, P., \& Morgan, L.E. (2005). Habitat-forming deep-sea corals in the Northeast Pacific Ocean. Cold-water corals and ecosystems, pp. 331-343. Springer, Berlin, Heidelberg. 
Fabricius, K.E. (2005). Effects of terrestrial runoff on the ecology of corals and coral reefs: review and synthesis. Marine Pollution Bulletin, 50, 125-146.

Fabricius, K.E., Logan, M., Weeks, S., Brodie, J. (2014). The effects of river run-off on water clarity across the central Great Barrier Reef. Marine Pollution Bulletin, 84, 191-200.

FAO. (2008). International guidelines for the management of deep sea fisheries in the high seas. FAO Technical Consultation Document, FAO, Rome.

FAO. (2009). Report of the technical consultation on international guidelines for the management of deepsea fisheries in the high seas Rome: Food and Agriculture Organization of the United Nations. Report no. 881.

Fautin, D.G., \& R.N. Mariscal. (1991). Cnidaria: Anthozoa, p. 267-358. In F. W. Harrison and J. A. Westfall [eds.], Placozoa, Porifera, Cnidaria, and Ctenophora. Microscopic Anatomy of Invertebrates. Wiley-Liss.

Ferré, B., De Madron, X.D., Estournel, C., Ulses, C., Le Corre, G. (2008). Impact of natural (waves and currents) and anthropogenic (trawl) resuspension on the export of particulate matter to the open ocean: application to the Gulf of Lion (NW Mediterranean). Continental Shelf Research, 28, 2071-2091.

Fettweis, M., Franckena, F., Van den Eyndea, D., Verwaestb, T., Janssensb, J., Van Lanckera, V. (2010). Storm influence on SPM concentrations in a coastal turbidity maximum area with high anthropogenic impact (southern North Sea). Continental Shelf Research, 30, 1417-1427 Fiore, C.L., Baker, D.M., Lesser, M.P. (2013). Nitrogen Biogeochemistry in the Caribbean Sponge Xestospongia muta: A Source or Sink of Dissolved Inorganic Nitrogen? PLoS ONE, 8(8), e72961. doi:10.1371/journal.pone.0072961.

Foley, N.S., van Rensburg, T.M., Armstrong, C.W. (2011). The rise and fall of the Irish orange roughy fishery: an economic analysis. Marine Policy, 35, 756-63.

Fossa, J.H., Mortensen, P.B., Furevik, D.M. (2002). The deep-water coral Lophelia pertusa in Norwegian waters: distribution and fishery impacts. Hydrobiologia, 471, 1-12.

Fraschetti, S., Terlizzi, A., Guarnieri, G., Pizzolante, F., D'Ambrosio, P., Maiorano, P., Beqiraj, S., Boero, F. (2011). Effects of unplanned development on marine biodiversity: a lesson from Albania (central Mediterranean Sea). Journal of Coastal Research, 58, 106-115. 
Freiwald, A., Fosså, J.H., Grehan, A., Koslow, T., Roberts, J.M. (2004). Cold-water coral reefs. Out of sight no longer out of mind. UNEP-WCMC. Page 84, Cambridge, UK.

Freiwald, A., Hühnerbach, V., Lindberg, B., Wilson, J.B., Campbell, J. (2002). The Sula reef complex, Norwegian shelf. Facies, 47, 179-200.

Galloway, S.B., Work, T.M., Bochsler, V.S., Harley, R.A., Kramarsky-Winters, E., McLaughlin, S.M., Meteyer, C.U., Morado, J.F., Nicholson, J.H., Parnell, P.G., Peters, E.C., Reynolds, T.L., Rotstein, D.S., Sileo, L., Woodley, C.M. (2007). Coral Disease and Health Workshop: Coral Histopathology II. NOAA Technical Memorandum NOS NCCOS 56 and NOAA Technical Memorandum CRCP 4. National Oceanic and Atmospheric Administration, Silver Spring, MD. 84p.

GESAMP (2001). Protecting the oceans from land-based activities. Land-based sources and activities affecting the quality and uses of the marine, coastal and associated freshwater environment. United Nations Environment Program, Nairobi.

Gili, J. M., \& Coma, R. (1998). Benthic suspension feeders: their paramount role in littoral marine food webs. Trends in Ecology \& Evolution, 13, 316-321.

Glover, A.G., \& Smith, C.R. (2003) The deep-sea floor ecosystem: current status and prospects of anthropogenic change by the year 2025. Environmental Conservation, 30, 219-241.

Gollner, S., Kaiser, S., Menzel, L., Jones, D.O., Brown, A., Mestre, Van Oevelen, D., Menot, L., Colaço, A., Canals, M. and Cuvelier, DN.C., Cuvelier, D. (2017). Resilience of benthic deep-sea fauna to mining activities. Marine Environmental Research, 129, 76-101.

Goode, S.L., Rowden, A.A., Bowden, D.A., Clark, M.R. (2020). Resilience of seamount benthic communities to trawling disturbance. Marine Environmental Research, 161. <http://dx.doi.org/10.1016/j.marenveres.2020.105086>

Grant, N., Matveev, E., Kahn, A.S., Archer, S.K., Dunham, A., Bannister, R.J., ErrkesMedrano, D., Leys, S.P. (2019). Effect of suspended sediments on the pumping rates of three species of glass sponge in situ. Marine Ecology Progress Series, 615, 79-100.

Grant, N., Matveev, E., Kahn, A.S., Leys, S.P. (2018). Suspended sediment causes feeding current arrests in situ in the glass sponge Aphrocallistes vastus. Marine Environmental Research, 137, 111-120. 
Gray, J.S., Clarke, K.R., Warwick, R.M., Hobbs, G. (1990). Detection of initial effects of pollution on marine benthos: an example from the Ekofisk and Eldfisk oilfields, North Sea. Marine Ecology Progress Series, 285-299.

Grossart, H. P., \& Ploug, H. (2001). Microbial degradation of organic carbon and nitrogen on diatom aggregates. Limnology and Ooceanography, 46, 267-277.

Hall-Spencer, J., Allain, V., Fossa, J.H. (2002) Trawling damage to Northeast Atlantic ancient coral reefs. Proceedings of the Royal Society of London. Series B: Biological Sciences, 269, $507-511$.

Halpern, B.S., Walbridge, S., Selkoe, K.A., Kappel, C.V., Micheli, F., D’Agrosa, C., Bruno, J.F., Casey, K.S., Ebert, C., Fox, H.E., Fujita, R., Heinemann, D., Lenihan, H.S., Madin, E.M.P., Perry, M.T., Selig, E.R., Spalding, M., Steneck, R., Watson, R. (2008). A global map of human impact on marine ecosystems. Science, 319, 948-952.

Hanley, J. (2011) Environmental monitoring programs on recent capitaial dredging projects in the Pilbara (2003-10): a Review. The APPEA Journal, 51, 273-294.

Henry, L.A., Navas, J.M., Hennige, S.J., Wicks, L.C., Vad, J., Roberts, J.M. (2013). Coldwater coral reef habitats benefit recreationally valuable sharks. Biological Conservation, 161, $67-70$.

Hoegh-Guldberg, O., \& Bruno, J.F. (2010). The Impact of Climate Change on the World's Marine Ecosystems. Science, 328, 1523-1528. doi:10.1126/science.1189930.

Howarth, R. W., \& Marino, R. (2006). Nitrogen as the limiting nutrient for eutrophication in coastal marine ecosystems: evolving views over three decades. Limnology and Oceanography, $51,364-376$.

Husebo, A., Nottestad, L., Fossa, J.H., Furevik, D.M., Jorgensen, S.B. (2002). Distribution and abundance of fish in deep-sea coral habitats. Hydrobiologia, 471, 91-99.

Ilan, M., \& Abelson, A. (1995). The life of a sponge in a sandy lagoon. The Biological Bulletin, 189, 363-369.

IOC/UNESCO, FAO, UNDPA Blueprint for Ocean and Coastal Sustainability (2011). 
Järnegren, J., Brooke, S., Jensen, H. (2017). Effects of drill cuttings on larvae of the cold-water coral Lophelia pertusa. Deep Sea Research Part II: Topical Studies in Oceanography, 137, 454-462.

Jiménez, E., \& Ribes, M. (2007). Sponges as a source of dissolved inorganic nitrogen: nitrification mediated by temperate sponges. Limnology and Ooceanography, 52, 948-958.

Jones, R., Bessell-Browne, P., Fisher, R., Klonowski, W., Slivkoff, M. (2016). Assessing the impacts of sediments from dredging on corals. Marine Pollution Bulletin 102, 9-29. DOI 10.1016/j.marpolbul.2015.10.049.

Kahn, A.S., Yahel, G., Chu, J.W., Tunnicliffe, V., Leys, S.P. (2015). Benthic grazing and carbon sequestration by deep-water glass sponge reefs. Limnology and Oceanography, 60, 7888.

Keller, B.D., Gleason, D.F., McLeod, E., Woodley, C.M., Airamé, S., Causey, B.D., Friedlander, A.M., Grober-Dunsmore, R., Johnson, J.E., Miller, S.L., Steneck, R.S. (2009). Climate Change, Coral Reef Ecosystems, and Management Options for Marine Protected Areas. Environmental Management, 44, 1069-1088. doi:10.1007/s00267-009-9346-0

Kelly, M., Edwards, A.R., Wilkinson, M.R., Alvarez, B., Cook, S., Bergquist, P.R., Buckeridge, J.S., Campbell, H.J., Reiswig, H.M., Valentine, C., Vacelet, J. (2009). Phylum Porifera - sponges. New Zealand Inventory of Biodiversity 1. Canterbury University Press: 2346.

Kirk, J. (1985). Effects of suspensoids (turbidity) on penetration of solar radiation in aquatic ecosystems. Hydrobiologia, 125, 195-208.

Klitgaard, A.B., \& Tendal, O.S. (2004). Distribution and species composition of mass occurrences of large-sized sponges in the northeast Atlantic. Progress in Oceanography, 61, $57-98$.

Knapp, I.S.S., Williams, G.J., Carballo, J.L., Cruz-Barraza, J.A., Gardner, J.P.A., Bell, J.J. (2013). Restriction of sponges to an atoll lagoon as a result of reduced environmental quality. Marine Pollution Bulletin, 66, 209-220.

Koenig, C.C., Shepard, A.N., Reed, J.K., Coleman, F.C., Brooke, S.D., Brusher, J., Scanlon, K.M. (2005). Habitat and Fish Populations in the Deep-Sea populations in the Deep-Sea 
Oculina Coral Ecosystem of the Western Atlantic. American Fisheries Society Symposium, $41,795-805$.

Koopmans, M., Martens, D., Wijffels, R.H. (2010). Growth efficiency and carbon balance for the sponge Haliclona oculata. Marine Bbiotechnology, 12, 340-349.

Koslow, J.A., Gowlett-Holmes, K., Lowry, J.K., O'Hara, T., Poore, G.C.B., Williams, A. (2001). Seamount benthic macrofauna off southern Tasmania: community structure and impacts of trawling. Marine Ecology Progress Series, 213, 111-125. <http://dx.doi.org/10.3354/meps213111>

Kroon, F.J. (2012). Towards ecologically relevant targets for river pollutant loads to the Great Barrier Reef. Marine Pollution Bulletin, 65, 261-266.

Kutti, T., Bannister, R. J., Fosså, J. H. (2013). Community structure and ecological function of deepwater sponge grounds in the Traenadypet MPA—Northern Norwegian continental shelf. Continental Shelf Research, 69, 21-30.

Larcombe, P., Ridd, P.V., Prytz, A., Wilson, B. (1995). Factors controlling suspended sediment on inner-shelf coral reefs, Townsville, Australia. Coral Reefs, 14, 163-171.

Larsson, A., \& Purser, A. (2011). Sedimentation on the cold-water coral Lophelia pertusa: cleaning efficiency from natural sediments and drill cuttings. Marine Pollution Bulletin, 62, 1159-1168.

Larsson, A.I., van Oevelen, D., Purser, A., Thomsen, L. (2013). Tolerance to long-term exposure to suspended benthic sediments and drill cuttings in the cold-water coral Lophelia pertusa. Marine Pollution Bulletin, 70, 176-188.

Lemloh, M.L., Fromont, J., Brümmer, F., Usher, K.M. (2009). Diversity and abundance of photosynthetic sponges in temperate Western Australia. BMC ecology, 9, 1-13.

Lepland, A., Mortensen, P.B. (2008). Barite and barium in sediments and coral skeletons around the hydrocarbon exploration drilling site in the Træna Deep, Norwegian Sea. Environmental Geology, 56, 119-129. https://doi.org/10.1007/s00254-007-1145-4.

Lesser, M.P., \& Slattery, M. (2013). Ecology of Caribbean sponges: are top-down or bottomup processes more important? PLoS ONE, 8, e79799. doi:10.1371/journal.pone.0079799 
Levin, L.A., Mengerink, K., Gjerde, K.M., Rowden, A.A., Van Dover, C.L., Clark, M.R., Ramirez-Llodra, E., Currie, B., Smith, C.R., Gallo, N. (2016). Defining "serious harm" to the marine environment in the context of deep-seabed mining. Marine Policy, 74, 245-259.

Liu, P.J., Hsin, M.C., Huang, Y.H., Fan, T.Y., Meng, P.J., Lu, C.C., Lin, H.J. (2015). Nutrient enrichment coupled with sedimentation favors sea anemones over corals. PloS one, 10, $\mathrm{e} 0125175$.

Lohrer, A.M., Hewitt, J.E., Thrush, S.F. (2006). Assessing far-field effects of terrigenous sediment loading in the coastal marine environment. Marine Ecology Progress Series, 315, 1318.

Longo, C., Mastrototaro, F., Corriero, G. (2005). Sponge fauna associated with a Mediterranean deep-sea coral bank. Journal of the Marine Biological Association of the United Kingdom, 85, 1341-1352.

Lotze, H.K., Lenihan, H.S., Bourque, B.J., Bradbury, R.H., Cooke, R.G., Kay, M.C., Kidwell, S.M., Kirby, M.X., Peterson, C.H., Jackson, J.B. (2006). Depletion, Degradation, and Recovery Potential of Estuaries and Coastal Seas. Science, 312, 1806-1809. 10.1126/science.1128035.

Luter, H.M., Gibb, K., Webster, N.S. (2014). Eutrophication has no short-term effect on the Cymbastela stipitata holobiont. Frontiers in Microbiology, 5, 216.

MacKay, K.A., Wood, B.A., Clark, M.R. (2005). Chatham Rise Bathymetry. NIWA Miscellaneous Chart Series 82. NIWA.

Maldonado, M., Aguilar, R., Bannister, R.J., Bell, J.J., Conway, K.W., Dayton, P.K., Díaz, C., Gutt, J., Kelly, M., Kenchington, E.L., Leys, S.P. (2017). Sponge grounds as key marine habitats: a synthetic review of types, structure, functional roles, and conservation concerns. Marine Animal Forests: The Ecology of Benthic Biodiversity Hotspots, 145-183.

Maldonado, M., Giraud, K., Carmona, C. (2008). Effects of sediment on the survival of asexually produced sponge recruits. Marine Biology, 154, 631-641.

Mallela, J., Roberts, C., Harrod, C., Goldspink, C.R. (2007). Distributional patterns and community structure of Caribbean coral reef fishes within a river-impacted bay. Journal of Fish Biology, 70, 523e537.

McCook, L., Schaffelke, B., Apte, S., Brinkman, R., Brodie, J., Erftemeijer, P., Eyre, B., Hoogerwerf, F., Irvine, I., Jones, R. and King, B. (2015). Synthesis of current knowledge of 
the biophysical impacts of dredging and disposal on the Great Barrier Reef: report of an independent panel of experts. Great Barrier Reef Marine Park Authority.

McDole, T., Nulton, J., Barott, K. L., Felts, B., Hand, C., Hatay, M., Lee, H., Nadon, M.O., Nosrat, B., Salamon, P., Bailey, B. (2012). Assessing coral reefs on a Pacific-wide scale using the microbialization score. PLoS One, 7(9), e43233.

McGrath, E.C., Smith, D.J., Jompa, J., Bell, J.J. (2017). Adaptive mechanisms and physiological effects of suspended and settled sediment on barrel sponges. Journal of experimental Marine Biology and Ecology, 496, 74-83.

McMurray, S., Stubler, A., M. Erwin, P., Finelli, C., R. Pawlik, J. (2018). A test of the spongeloop hypothesis for emergent Caribbean reef sponges. Marine Ecology Progress Series, 588, $1-14$.

Miller, D.C., Muir, C.L., Hauser, O.A. (2002). Detrimental effects of sedimentation on marine benthos: what can be learned from natural processes and rates? Ecological Engineering, 19, 211-232.

Miller, K.A., Thompson, K.F., Johnston, P., Santillo, D. (2018). An Overview of Seabed Mining Including the Current State of Development, Environmental Impacts, and Knowledge Gaps. Frontiers in Marine Science, 4, 418. 〈http://dx.doi.org/10.3389/fmars.2017.00418>

Ministry for Primary Industries (2017). Aquatic Environment and Biodiversity Annual Review 2017. Compiled by the Fisheries Science Team, Ministry for Primary Industries, Wellington, New Zealand. 724p.

Ministry for the Environment and Statistics New Zealand., (2015). New Zealand's environmental reporting series: Environment Aotearoa 2015. Available from: www. mfe.govt.nz.

Mueller, B., de Goeij, J. M., Vermeij, M. J. A., Mulders, Y., van der Ent, E., Ribes, M., van Duyl, F. C. (2014). Natural Diet of Coral-Excavating Sponges Consists Mainly of Dissolved Organic Carbon (DOC). PLoS ONE, 9(2), e90152. doi:10.1371/journal.pone.0090152.

Müller, W.E.G. (2003). The Origin of Metazoan Complexity: Porifera as Integrated Animals1. Integrative and Comparative Biology, 43, 3-10. doi:10.1093/icb/43.1.3

Murillo, F.J., Muñoz, P.D., Cristobo, J., Ríos, P., González, C., Kenchington, E., \& Serrano, A. (2012). Deep-sea sponge grounds of the Flemish Cap, Flemish Pass and the Grand Banks 
of Newfoundland (Northwest Atlantic Ocean): distribution and species composition. Marine Biology Research, 8, 842-854.

Murray, H.J.R. (2009). Oxygen consumption rates of sponges and the effect of UV-B radiation and sediment. MSc thesis, Victoria University of Wellington.

Nava, H., \& Carballo, J.L. (2013). Environmental factors shaping boring sponge assemblages at Mexican Pacific coral reefs. Marine Ecology, 34, 269-279.

NOAA (2010). NOAA Strategic Plan for Deep-Sea Coral and Sponge Ecosystems: Research, Management, and International Cooperation. Silver Spring, MD: NOAA Coral Reef Conservation. Conservation Program. 11. Silver Spring, MD, USA, pp. 67.

NZ EPA (2015). Decision on Marine Consent Application Chatham Rock Phosphate Limited to Mine Phosphorite Nodules on the Chatham Rise. Available online at: https://cer.org.za/wpcontent/uploads/2016/08/EPA-New-Zealand-Chatham-Rock-Phosphate-Decision.pdf

Pawar P.R. (2016). Anthropogenic threats to coastal and marine biodiversity: A review. International Journal of Modern Biological Research/ IJMBR 4, 35-45.

Pawlik, J. R., Loh, T.L., McMurray, S.E., Finelli, C.M. (2013). Sponge communities on Caribbean coral reefs are structured by factors that are top-down, not bottom-up. PLoS ONE, 8, e62573. doi:10.1371/journal.pone.0062573

Petersen, S., Krätschell, A., Augustin, N., Jamieson, J., Hein, J. R., Hannington, M.D. (2016). News from the seabed-Geological characteristics and resource potential of deep-sea mineral resources. Marine Policy, 70, 175-187.

Peterson, B.J., Chester, C.M., Jochem, F.J., Fourqurean, J.W. (2006). Potential role of sponge communities in controlling phytoplankton blooms in Florida Bay. Marine Ecology Progress Series, 328, 93-103.

Pile, A.J., \& Young, C.M. (2006). The natural diet of a hexactinellid sponge: benthic-pelagic coupling in a deep-sea microbial food web. Deep Sea Research Part I: Oceanographic Research Papers, 53, 1148-1156.

Pile, A.J., Patterson, M.R., Savarese, M., Chernykh, V.I., Fialkov, V.A. (1997). Trophic effects of sponge feeding within Lake Baikal's littoral zone. 2. Sponge abundance, diet, feeding efficiency, and carbon flux. Limnology and Oceanography, 42, 178-184. 
Pineda, M.C., Strehlow, B., Sternel, M., Duckworth, A., Jones, R., Webster, N.S. (2017). Effects of suspended sediments on the sponge holobiont with implications for dredging management. Scientific Rreports, 7, 4925.

Pinkerton, M.H. (2017). Impacts of climate change on New Zealand fisheries and aquaculture. Climate Change Impacts on Fisheries and Aquaculture: A Global Analysis, 1, 91.

Pomponi, S. (1977). Excavation of calcium carbonate substrates by boring sponges: Ultrastructure and cytochemistry. Ph.D dissertation. University of Miami, Miami, Florida.

Postma, H. (1966). The cycle of nitrogen in the Wadden Sea and adjacent areas. Netherlands Journal of Sea Research, 3, 121-86.

Ragnarsson, S.Á., Burgos, J.M., Kutti, T., van den Beld, I., Egilsdóttir, H., Arnaud-Haond, S., Grehan, A. (2017). The impact of anthropogenic activity on cold-water corals. Marine Animal Forests, 1-35.

Ramirez-Llodra, E., Trannum, H.C., Evenset, A., Levin, L.A., Andersson, M., Finne, T.E., Hilaro, A., Flem, B., Christensen, G., Schaanning, M., Vanreusel, A. (2015). Submarine and deep-sea mine tailing placements: a review of current practices, environmental issues, natural analogs and knowledge gaps in Norway and internationally. Marine Pollution Bulletin, 97, 1335.

Reed, J.K., Koenig, C.C., Shepard, A.N. (2007). Impacts of bottom trawling on a deep-water Oculina coral ecosystem off Florida. Bulletin of Marine Sciences, 81, 481-496.

Reiswig, H.M. (1971). Particle feeding in natural populations of three marine demosponges. The Biological Bulletin, 141, 568-591. doi:10.2307/1540270.

Reiswig, J.K., (1974). Water transport, respiration, and energetics of three tropical marine sponges. Journal of Experimental Marine Biology and Ecology, 14, 231-249.

Relini, G. (2012). Threats to marine biodiversity in the Mediterranean. www.oceano.org

Ribeiro, S.M., Omena, E.P., Muricy, G. (2003). Macrofauna associated to Mycale microsigmatosa (Porifera Demospongiae) in Rio de Janeiro State, SE Brazil. Estuarine, Coastal and Shel Science. 57, 951-959. 
Ribes, M., Coma, R., Gili, J.M. (1999). Natural diet and grazing rate of the temperate sponge Dysidea avara (Demospongiae, Dendroceratida) throughout an annual cycle. Marine Ecology Progress Series, 176, 179-190.

Ricardo, G.F., Jones, R.J., Negri, A.P., Stocker, R. (2016). That sinking feeling: suspended sediments sediments can prevent the ascent of coral egg bundles. Scientific Reports. 6, 21567.

Riegl, B. (1995). Effects of sand deposition on scleractinian and alcyonacean corals. Marine Biology, 121, 517-526.

Riisgaard, H.U., \& Larsen, P.S. (1995). Filter-feeding in marine macro-invertebrates: Pump characteristics, modelling and energy cost. Biological Reviews, 70, 67-106.

Risk, M.J. (2014). Assessing the effects of sediments and nutrients on coral reefs. Current Opinion in Environmental Sustainability, 7, 108-117.

Rix, L., De Goeij, J.M., Mueller, C.E., Struck, U., Middelburg, J.J., Van Duyl, F.C., Al-Horani, F.A., Wild, C., Naumann, M.S. and Van Oevelen, D. (2016). Coral mucus fuels the sponge loop in warm-and cold-water coral reef ecosystems. Scientific Reports, 6, 1-11.

Rix, L., de Goeij, J.M., van Oevelen, D., Struck, U., Al-Horani, F.A., Wild, C. and Naumann, M.S. (2017). Differential recycling of coral and algal dissolved organic matter via the sponge loop. Functional Ecology, 31, pp.778-789.

Roberts J.M., Wheeler A.J., Freiwald A., Cairns, S. (2009). Cold-water corals. The biology and geology of deep-sea coral habitats. Cambridge University Press, Cambridge.

Roberts, D.E., Davis, A.R., Cummins, S.P. (2006a). Experimental manipulation of shade, silt, nutrients and salinity on the temperate reef sponge Cymbastela concentrica. Marine Ecology Progress Series, 307, 143-154.

Roberts, D.E., Smith, A., Ajani, P., Davis, A.R. (1998). Rapid changes in encrusting marine assemblages exposed to anthropogenic point-source pollution: a 'Beyond BACI' approach. Marine Ecology Progress Series, 163, 213-224.

Roberts, J.M., Wheeler, A.J., Freiwald, A. (2006b). Reefs of the deep: the biology and geology of cold-water coral ecosystems. Science, 312, 543-547.

Roberts, S., Hirshfield, M. (2004). Deep-sea corals: out of sight, but no longer out of mind. Frontiers in Ecology and the Environment, 2, 123-130. 
Rogers, A. (2004). The Biology, Ecology and Vulnerability of Deep-water Coral Reefs. IUCN. Rogers, A.D. (1999). The biology of Lophelia pertusa (Linnaeus 1758) and other deep-water reef-forming corals and impacts from human activities. International Review of Hydrobiology, $84,315-406$.

Rogers, C.S. (1990). Responses of coral reefs and reef organisms to sedimentation. Marine Ecology Progress Series, 62, 185-202.

Rubin-Blum, M., Antony, C.P., Sayavedra, L., Martínez-Pérez, C., Birgel, D., Peckmann, J., Cardenas, P., MacDonald, I., Marcon, Y., Sahling, H., Hentschel, U, Dubilier, N. (2019). Fueled by methane: deep-sea sponges from asphalt seeps gain their nutrition from methaneoxidizing symbionts. The ISME Journal: Multidisciplinary Journal of Microbial Ecology, 13, $1209-1225$.

Scanes, E., Kutti, T., Fang, J.K., Johnston, E.L., Ross, P.M., Bannister, R.J. (2018). Mine waste and acute warming induce energetic stress in the deep-sea sponge Geodia atlantica and coral Primnoa resedeaformis; results from a mesocosm study. Frontiers in Marine Science, 5, 129.

Schoellhamer, D.H. (1996). Anthropogenic sediment resuspension mechanisms in a shallow microtidal estuary. Estuarine and Coastal Shelf Science, 43, 533-548.

Schoellhamer, D.H., Mumley, T.E., Leatherbarrow, J.E. (2007). Suspended sediment and sediment associated contaminants in San Francisco Bay. Environmental Research, 105, 119131.

Schönberg, C.H.L. (2016). Happy relationships between marine sponges and sediments-a review and some observations from Australia. Journal of the Marine Biological Association of the United Kingdom, 96, 93-514.

Schwarz, A.M., Taylor, R., Hewitt, J., Philips, N., Shima, Cole, R., Budd, R. (2006). Impacts of terrestrial runoff on the biodiversity of rocky reefs. New Zealand Aquatic Environment and Biodiversity Report, No. 7, 109.

Schwarz, A.M., Taylor, R., Hewitt, J., Philips, N., Shima, J., Cole, R., Budd, R. (2006). Impacts of terrestrial runoff on the biodiversity of rocky reefs. New Zealand Aquatic Environment and Biodiversity, Report 7, 1176-9440. 
Selman, M., Greenhalgh, S., Diaz, R., Sugg, Z. (2008). Eutrophication and hypoxia in coastal areas: a global assessment of the state of knowledge. Water Quality: Eutrophication and Hypoxia Policy Note Series No. 1. World Resources Institute, Washington, DC.

Shears, N.T. (2007). Biogeography, community structure and biological habitat types of subtidal reefs on the South Island West Coast, New Zealand. Science \& Technical Publishing., Department of Conservation.

Siciliano, A., Schiel, D.R., Thomsen, M.S. (2019). Effects of local anthropogenic stressors on a habitat cascade in an estuarine seagrass system. Marine and Freshwater Research, 70, 11291142.

Simister, R., Taylor, M. W., Tsai, P., Webster, N. (2012). Sponge-microbe associations survive high nutrients and temperatures. PLoS One, 7, e52220.

Simpson, T. (2012). The cell biology of sponges. In: Springer, Berlin Heidelberg New York. Springer Science \& Business Media.

Smith, V.H. (2003). Eutrophication of freshwater and coastal marine ecosystems a global problem. Environmental Science and Pollution Research, 10, 126-139.

Stender, Y., Jokiel, P.L., Rodgers, K.S., (2014). Thirty years of coral reef change in relation to coastal construction and increased sedimentation at Pelekane Bay, Hawai'I. PeerJ 2, e300.

Storlazzi, C.D., Field, M.E., Bothner, M.H., Presto, M.K., Draut, A.E., (2009). Sedimentation processes in a coral reef embayment: Hanalei Bay, Kauai. Marine Geology, 264, 140-151.

Taylor, M.W., Radax, R., Steger, D., Wagner, M. (2007). Sponge-associated microorganisms: Evolution, ecology, and biotechnological potential. Microbiology and Molecular Biology Reviews, 71, 295-397. doi:10.1128/mmbr.00040-06

Thrush, S., Hewitt, J., Cummings, V., Dayton, P. (1995). The impact of habitat disturbance by scallop dredging on marine benthic communities: what can be predicted from the results of experiments? Marine Ecology Progress Series, 129, 141-150.

Tilman, D., Fargione, J., Wolff, B., D' Antonio, C., Dobson, A., Howarth, R., Schindler, D., Schlesinger, W.H., Simberloff, D. Swackhamer, D. (2001). Forecasting agriculturally driven global environmental change. Science, 292, 281-284. 
Tjensvoll, I., Kutti, T., Fosså, J.H., Bannister, R.J. (2013). Rapid respiratory responses of the deepwater sponge Geodia barretti exposed to suspended sediments. Aquatic Biology, 19, 6573.

Tompkins-MacDonald, G.J., Leys, S.P. (2008). Glass sponges arrest pumping in response to 48. sediment: implications for physiology of the hexactinellid conduction system. Marine Biology, 154, 973-984.

Tracey, D., Hjorvarsdottir, F. (2019). The state of knowledge of deep-sea corals in the New Zealand region. NIWA Science and Technology Series Number 84. 140 p.

Tracey, D.M., Rowden, A.A., Mackay, K.A., Compton, T. (2011). Habitat-forming cold-water corals show affinity for seamounts in the New Zealand region. Marine Ecology Progress Series, $430,1-22$.

Trannum, H.C., Nilsson, H.C., Schaaning, M.T., Øxnevad, S. (2010). Effects of sedimentation from water-based drill cuttings and natural sediment on benthic macrofaunal community structure and ecosystem processes. Journal of Experimental Marine Biology and Ecology, 383, $111-121$.

Vacelet, J., \& Donadey, C. (1977). Electron microscope study of the association between some sponges and bacteria. Journal of Experimental Marine Biology and Ecology, 30, 301-3314.

Vacelet, J., Boury-Esnault, N., Fiala-Medioni, A., Fisher, C. R. (1995). A methanotrophic carnivorous sponge. Nature: International Weekly Journal of Science, 6547.

Vacelet, J., Fiala-Médioni, A., Fisher, C. R., \& Boury-Esnault, N. (1996). Symbiosis between methaneoxidizing bacteria and a deep-sea carnivorous cladorhizid sponge. Marine Ecology Progress Series, 145, 77-85.

van Oevelen, D., Duineveld, G., Lavaleye, M., Mienis, F., Soetaert, K., \& Heip, C.H. (2009). The cold-water coral community as hotspot of carbon cycling on continental margins: A foodweb analysis from Rockall Bank (northeast Atlantic). Limnology and Oceanography, 54, $1829-1844$.

Van Soest, R.W.M., Boury-Esnault, N., Vacelet, J., Dohrmann, M., Erpenbeck, D., De Voogd, N.J., Santodomingo, N., Vanhoorne, B., Kelly, M., Hooper, J.N.A. (2012). Global Diversity of Sponges (Porifera). PLoS ONE, 7, e35105. doi:10.1371/journal.pone.0035105 
Wahab, M.A.A., Maldonado, M., Luter, H.M., Jones, R., Ricardo, G. (2019). Effects of sediment resuspension on the larval stage of the model sponge Carteriospongia foliascens. Science of the Total Environment, 695, 133837.

Wendt, P.H., Van Dolah, R.F., O'rourke, C.B. (1985). A comparative study of the invertebrate macrofauna associated with seven sponge and coral species collected from the South Atlantic Bight. Journal of the Elisha Mitchell Scientific Society, 187-203.

Whalan, S., Battershill, C., de Nys, R. (2007). Sexual reproduction of the brooding sponge Rhopaloeides odorabile. Coral Reefs, 26, 655-663.

Whalan, S., Battershill, C., De Nys, R., (2007b). Variability in reproductive output across a water quality gradient for a tropical marine sponge. Marine Biology, 153, 163-169.

White, M., Wolff, G.A., Lundälv, T., Guihen, D., Kiriakoulakis, K., Lavaleye, M., Duineveld, G. (2012). Cold-water coral ecosystem (Tisler Reef, Norwegian Shelf) may be a hotspot for carbon cycling. Marine Ecology Progress Series, 465, 11-23.

Wilkinson, C.R., \& Cheshire, A.C. (1989). Patterns in the distribution of sponge populations across the central Great Barrier Reef. Coral Reefs, 8, 127-134.

Wilkinson, C.R., \& Evans, E. (1989). Sponge distribution across Davies Reef, Great Barrier Reef, relative to location, depth, and water movement. Coral Reefs, 8, 1-7.

Williams, A., Althaus, F., Maguire, K., Green, M., Untiedt, C., Alderslade, P., Clark, M.R., Bax, N., Schlacher, T.A. (2020). The Fate of Deep-Sea Coral Reefs on Seamounts in a FisherySeascape: What Are the Impacts, What Remains, and What Is Protected? Frontiers in Marine Science, 7, 798. <http://dx.doi.org/10.3389/fmars.2020.567002>

Williams, A., Schlacher, T.A., Rowden, A.A., Althaus, F., Clark, M.R., Bowden, D.A., Stewart, R., Bax, N.J., Consalvey, M., Kloser, R.J. (2010). Seamount megabenthic assemblages fail to recover from trawling impacts. Marine Ecology, 31, 183-199.

Wolanski, E., Fabricius, K., Spagnol, S., Brinkman, R. (2005). Fine sediment budget on an inner-shelf coral-fringed island, Great Barrier Reef of Australia. Estuarine, Coastal and Shelf Science $65,153-158$.

Wulff, J.L. (2006). Ecological interactions of marine sponges. Canadian Journal of Zoology, 84, 146-166. doi:10.1139/Z06-019. 
Xavier, J.R., Tojeira, I., Van Soest, R.W.M. (2015). On a hexactinellid sponge aggregation at the Great Meteor seamount (North-east Atlantic). Journal of the Marine Biological Association of the United Kingdom, 95, 1389-1394.

Zhang, X., \& Pratt, B.R. (1994). New and extraordinary Early Cambrian sponge spicule assemblage from China. Geology, 22, 43-46. doi:10.1130/00917613(1994)022<0043:NAEECS>2.3.CO;2 


\section{Chapter 2. Responses of the common New Zealand coastal sponge, Crella incrustans, to elevated suspended sediments.}

\section{Abstract}

Elevated suspended sediment concentrations can affect the health of marine benthic fauna, particularly suspension feeders. Suspended sediment loads can become elevated through trawling and dredging, and via resuspension of bottom sediments and/or direct input from land during storms. I assessed the functioning (survival, respiration, morphology, and feeding) of a common New Zealand cushion sponge, Crella incrustans (Carter, 1885), during four weeks of exposure to a gradient of suspended sediment concentrations (SSCs). $94 \%$ of sponges survived, and respiration rates were not affected; particles clearance varied among sponges $\left(4 \times 10^{3}-1 \mathrm{x}\right.$ $10^{6}$ cells $\mathrm{h}^{-1} \mathrm{ml}^{-1} \mathrm{~g}(\mathrm{AFDW})^{-1}$, but was low across all treatments. Sponges developed apical fistules, a phenomenon never-before observed in this species. Although sediments accumulated internally within the sponges, around a third had cleared these sediments two weeks after the elevated SSCs were removed. The environments these sponges inhabit may predispose them to coping with high SSCs. Such experiments are useful for defining SSC tolerances, which may influence how such impacts can be managed.

\subsection{Introduction}

Coastal marine environments are under increasing pressure from many natural and anthropogenic impacts operating at a range of temporal and spatial scales (Crain et al., 2009; Halpern et al., 2015). Of concern globally is the increasing amount of sediment entering coastal systems through waterways as a result of changes in land use, deforestation, and agricultural practices (Airoldi, 2003; Syvitski et al., 2005), and being disturbed and redistributed in situ from activities such as coastal and offshore dredging, trawling and seabed mining (Erftemeijer et al., 2012; Levin et al., 2016; Paradis et al., 2018). While many organisms are able to withstand natural levels of suspended and deposited sediment in coastal regions (Larcombe et al., 1995; Wolanski et al., 2005; Storlazzi et al., 2009), sustained high sediment loads can impact the health of marine organisms and, therefore, overall ecosystem function (Thrush and Dayton, 2002).

While larger sediment particles tend to settle quickly after suspension, fine particles can remain in suspension for extended periods and be transported over long distances by currents (Capuzzo 
et al., 1985; Rolinski et al., 2001). This means the impact of high suspended sediment concentrations (SSCs) can occur some distance from the sediment disturbance source (Oebius et al., 2001; Fisher et al., 2015; Jones et al., 2019). Excessive sedimentation and sediment resuspension can significantly affect the abundance, diversity and structure of benthic communities (Airoldi, 2003; Fabricius, 2005; Carballo, 2006; Knapp et al., 2013). These effects range from burial and smothering by settling sediment, which can be fatal, to more chronic effects on biological processes such as reduced larval survival and recruitment, settlement, feeding efficiency and growth (Airoldi, 2003; Fabricius, 2005; Cheung and Shin, 2005; Lohrer et al., 2006; Walker, 2007). High SSCs in the water column can be particularly detrimental to benthic suspension feeders and may lead to clogging of their filtering apparatus, thus reducing their particle feeding efficiency and affecting growth, reproduction and other physiological processes (Ellis et al., 2002; Hewitt and Norkko, 2007).

Sponges (Phylum Porifera) are an important and diverse suspension feeding group (Wilkinson and Evans, 1989; Bell and Barnes, 2000; Murillo et al., 2012) that have important functional roles in benthic systems (Bell, 2008; Maldonado et al., 2017). In temperate regions, sponges can process large volumes of water and efficiently retain particulate and dissolved organic matter (Perea-Blázquez et al., 2012). While some sponge species can be found and even thrive in areas of high settled and suspended sediment (e.g. Bell and Barnes, 2000; Knapp et al., 2013), there is strong evidence, primarily from tropical species, that sediment is generally detrimental to sponges (Bell et al., 2015; but see Schönberg, 2016), and that their diversity and abundance are lower in high sediment environments (Leys et al., 2004; Bannister et al., 2012; Stubler et al., 2015). Exposure to suspended sediments has been reported to clog the aquiferous system and to reduce or arrest water pumping in several sponge species (Gerrodette \& Flechsig, 1979; Leys et al., 1999; Tompkins-MacDonald and Leys, 2008; Bannister et al., 2012; Strehlow et al., 2016; Grant et al., 2018). As pumping is required for feeding and respiration, clogging induced by fine sediments can compromise food particle retention (Lohrer et al., 2006) and oxygen consumption rates (Gerrodette \& Fleshing, 1979). Despite these reported impacts on pumping rates, respiration rates in sponges exposed to SSCs have shown contrasting responses. While some sponges showed decreased respiration rates when exposed to SSCs (Lohrer et al., 2006; Tjensvoll et al., 2013; Kutti et al., 2015; Pineda et al., 2017), others increased their oxygen consumption (Bannister et al., 2012; McGrath et al., 2017). Increased respiration rates may result from the sponges employing mechanisms to remove sediment from their aquiferous system, such as mucus production (see Biggerstaff et al., 2017; McGrath et al., 2017), while 
reduced respiration rates may result from a reduction in water pumping rates. A protracted reduction in sponge pumping has been correlated with reduced growth and lower survival (Roberts et al., 2006; Maldonado et al., 2008). These contrasting results highlight the difficulty in making generalisations about impacts of sediment on sponges, and the need for locationspecific and taxon-specific studies to understand suspended sediment impacts and determine SSC tolerance thresholds (e.g. Scanes et al., 2018).

In New Zealand, elevated sediment loads in coastal areas are recognized as a major threat to coastal biodiversity (Schwarz et al., 2006; Ministry for the Environment, 2015; Cussioli et al., 2019; Siciliano et al., 2019). Land-based activities such as agriculture, forestry, and urban development may have detrimental impacts on New Zealand's coastal marine environment through increased export of terrestrial sediments and their subsequent resuspension by coastal waves and currents (Thrush et al., 2004; Schwarz et al., 2006). Changes in rainfall patterns as a result of climate change, including increases in the magnitude and frequency of storm events (Reisinger et al., 2014; Law et al., 2018), are likely to result in more frequent input of sediments to coastal regions. Additionally, larger and more frequent storms will also result in greater and more frequent resuspension of coastal seafloor sediments (e.g. Orpin \& Ridd, 2012). Activities such as dredging and trawling are common around New Zealand, and known to resuspend sediments, which can persist in the water column for considerable time, and can thus influence widespread areas (Ellis et al., 2017).

Sponges are one of largest contributors to total biomass in many shallow water regions of New Zealand (Shears et al., 2007), particularly on rocky subtidal reefs (Kelly et al., 2009; Berman and Bell, 2010). To date, few studies have addressed the impacts of resuspended benthic sediments on New Zealand sponges (but see Murray, 2009), although comprehensive studies of impacts of terrestrial sediments (with predominantly silt/clay particles and very low acidity) have been conducted (Lohrer et al., 2006; Schwarz et al., 2006). There is need for more information to define environmentally relevant suspended sediment tolerance thresholds for sponges and to assess how they might respond to any future changes in SSCs, which in turn can influence how such impacts can be managed.

The aim of this chapter was to assess how the common shallow water and widely distributed New Zealand cushion sponge Crella incrustans (Carter, 1885) (Class: Demospongiae, Family: Crellidae) might respond to exposure to a range of elevated SSCs that could be encountered in 
the wild, and investigate whether there are thresholds of SSC beyond which normal functioning might become compromised.

\subsection{Material and methods}

\subsubsection{Sponge collection and maintenance}

The cushion sponge $C$. incrustans was used for this experiment. Multiple sponges, ranging in size from 5 to $15 \mathrm{~cm}$ in diameter, were collected from 4 to $9 \mathrm{~m}$ depth in Breaker Bay, Wellington, New Zealand, by SCUBA divers. Sponges were immediately transferred to flowthrough holding tanks in NIWA Wellington's Marine Environmental Manipulation Facility (MEMF), with seawater from the adjacent bay (filtered to $0.1 \mu \mathrm{m}$ ) at temperatures similar to those at the collection site $\left(16^{\circ} \mathrm{C}\right)$. Any epibionts were removed from the sponge surfaces before they were carefully sectioned into $\sim 3 \times 3 \mathrm{~cm}$ portions or 'clones', ensuring that each portion contained at least one osculum. Each 'clone' was then attached to a stainless steel mesh disc (4.5 cm diameter) using polyester thread (after Bates and Bell, 2018). Cutting of sponges is a common practice used to increase the sample size in experiments (Kutti et al., 2015; Bennett et al., 2017; Pineda et al., 2017). Previous experiments carried on C. incrustans (Bates and Bell, 2018) demonstrated that the health of this species is not compromised after being cut into 3 x $3 \mathrm{~cm}$ 'clones'. Sponge clones were subsequently left undisturbed for two weeks to allow membranes to reform (Bennett et al., 2017) and sponges to recover before being photographed (Nikon D850) and distributed randomly amongst 16 experimental chambers (N $=4$ per chamber). The sponges were fed daily with Nannochloropsis microalgae (1-2 $\mu \mathrm{m}$ cell diameter; Nanno $3600^{\mathrm{TM}}$ Reed Mariculture, U.S.). Sponges were handled entirely underwater, from their collection and during all stages of the experiment, to prevent stress from exposure to air.

\subsubsection{Experimental chambers}

Sixteen experimental chambers, each $38 \mathrm{~L}$ in volume and based on the Vortex resuspension tank design of Davies et al. (2009), were used to expose the experimental sponges to a range of SSCs. A vortex flow within the tanks was created by water being pumped into two vertical pipes using an aquarium pump (Eheim) positioned at the top of the tanks. A flow rate of $15 \mathrm{ml}$ $\mathrm{s}^{-1}$ was used to force the water through small jets to create a directional flow (Figure 2.1) and 
keep the sediment in suspension. Water jets in the lower half of the tank helped to re-suspend any settling sediment. Additionally, any sediment falling out of suspension that accumulated on the base of the chamber was pulled upwards by suction generated with an airlift system and subsequently reintroduced to the chamber via two outlets on a $\mathrm{T}$ bar pipe at the top of the chamber (Figure 2.1). Chambers were supplied with seawater at a rate of approximately $11 \mathrm{~h}^{-1}$. A $58 \mathrm{~cm}$ long outflow pipe increased the opportunity for any sediments within the outflow water to fall out of suspension (due to no vortex and low flow) within this outflow pipe. A $5 \mathrm{x}$ $5 \mathrm{~cm}$ square of polyester fibre placed in the outflow pipe also prevented sediment from leaving the system. This filter was cleared twice daily and any captured sediments reintroduced to the chamber.

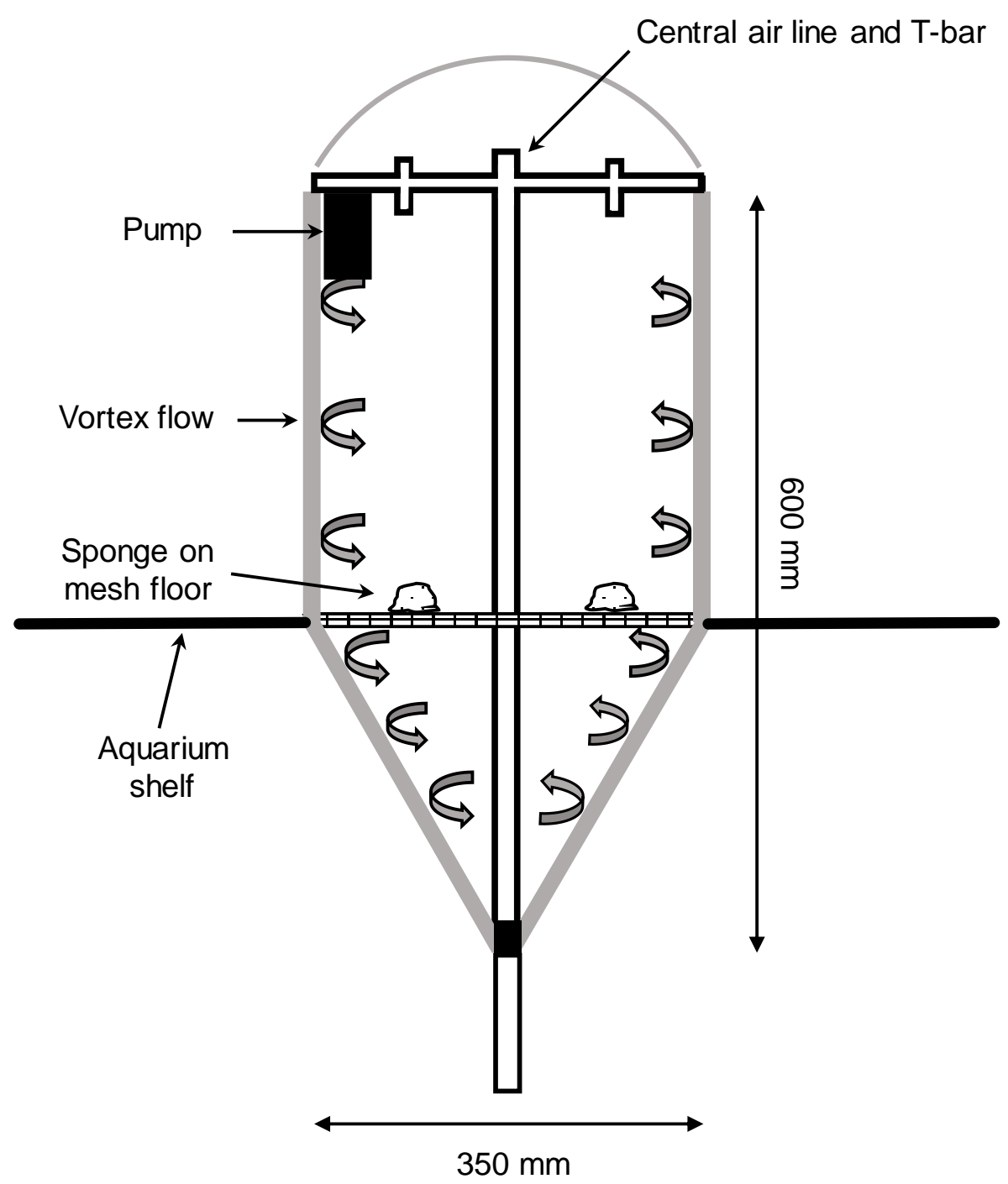

Figure 2.1. Schematic of an experimental chamber (38 1), showing details of the mechanisms used to keep sediments in suspension. 


\subsubsection{Sediment treatments}

Sponges were exposed to a gradient of suspended sediment concentrations (SSCs), ranging from a control (no added sediment) to a maximum of $\sim 832 \mathrm{mg} \mathrm{l}^{-1}$ (Figure 2.2). For this gradient design approach, no SSC replication occurred, i.e. the 16 chambers were used individually to be exposed to individual concentrations of SSC. SSCs were assigned randomly to the experimental chamber. Figure 2.2 shows average SSC in each chamber $( \pm \mathrm{SE})$. This gradient design method, with no SSC treatment replicates, was used in preference to a factorial design as I anticipated being able to generate response curves or to identify thresholds in the responses to SSCs (Kreyling et al., 2018), and to inform target SSCs for future experiments. SSC levels were chosen to encompass measured and modelled concentrations for coastal areas where these sponges are found (ranging from $\sim 10 \mathrm{mg}^{-1}$ to $200 \mathrm{mg} \mathrm{l}^{-1}$; M. Hadfield NIWA, pers. comm.), storm generated resuspension of bottom sediments, high SSCs generated via runoff from forestry roads during storms (e.g. $1000 \mathrm{mg}^{-1}$ in the Marlborough Sounds; Fahey and Coker, 1992), and to incorporate levels used in other studies (Kutti et al., 2015; Tjensvoll et al., 2013). Target SSCs were maintained for four weeks, after which time the chambers were cleaned of sediments and supplied with ambient seawater only for another two weeks to allow a 'recovery period'. Average SSC in each chamber were determined from water samples collected over 30 days. Each week, three $50 \mathrm{ml}$ water samples were collected from each chamber, filtered on predried and -weighed $25 \mathrm{~mm} \mathrm{GF/F}$ filters, and dried at $60{ }^{\circ} \mathrm{C}$ for $16 \mathrm{~h}$. Mean SSCs in the chambers were calculated from the values obtained by the weekly sampling. 


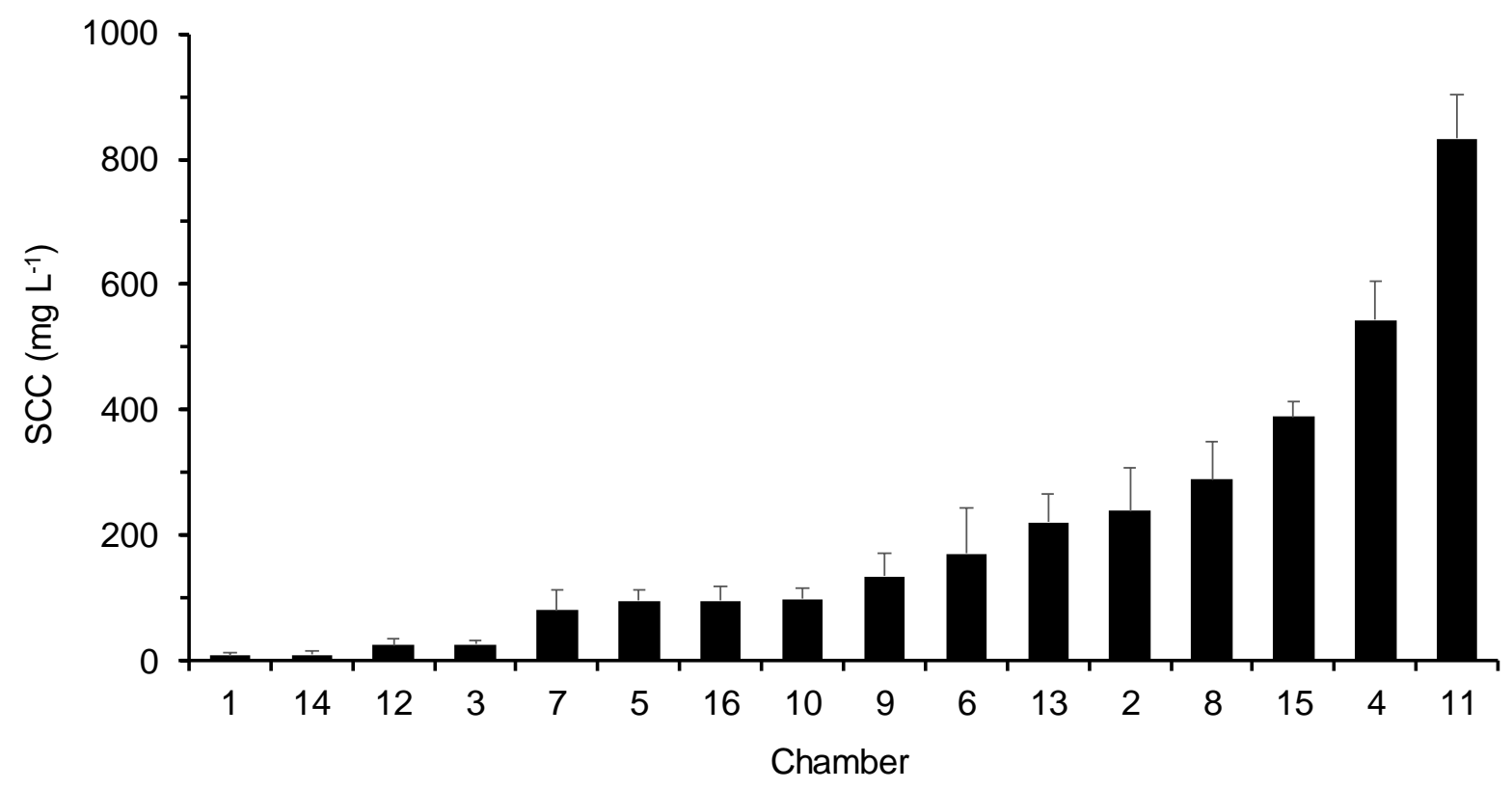

Figure 2.2. The range of suspended sediment concentrations (SSC) used in the experiment. Data presented are means (+ SE) of samples taken from a chamber on four separate occasions.

The SSCs were obtained by adding a slurry of sediment ( $\sim 15 \mathrm{ml}$; particle size range from 3 to $125 \mu \mathrm{m}$; mean diam. $54 \mu \mathrm{m}$ ) to each chamber. The sediment had been sourced from a inlet, north of Wellington, with a Van Veen grab. The surface sediment layer was used for the experiment. Sediment was defaunated by freezing, then thawed and dried at $110{ }^{\circ} \mathrm{C}$ for $24 \mathrm{~h}$. To ensure that target concentrations were maintained, chamber SSCs were monitored twice daily using a hand-held optical turbidity meter (Seapoint Turbidity meter) connected to a multimeter which displayed $\mathrm{mV}$. The relationship between $\mathrm{mV}$ and SSC had previously been determined for a broad range of concentrations of the specific sediment used in this study (Appendix one, Figure A1.1). If required, more sediment was added to the chambers after each monitoring check, with the quantity of sediment required determined by the difference between target $\mathrm{mV}$ and actual $\mathrm{mV}$ within the chamber, using the calibration curve (Appendix one, Figure A1.2). The weekly water samples referred to above were collected immediately prior to $\mathrm{mV}$ readings being taken for SSC monitoring. These provided additional confirmation of the relationship between SSC and $\mathrm{mV}$ determined during the pre-experimental calibration curve generation, and that it was maintained during the experiment. The particle size distribution of the sediment suspended in the water column (and thus, to which the sponges were actually exposed) was determined from water samples (each $30 \mathrm{ml}$ ) in five of the highest SSC chambers $\left(\mathrm{SSC}=135,221,288,389,544\right.$ and $\left.832 \mathrm{mg} \mathrm{l}^{-1}\right)$. Water samples were collected adjacent to the sponges in the chambers, on Days 5 and 29, (near the beginning and end, respectively, of the elevated SSC portion of the experiment). Samples were analysed for particle size using a 
Beckman Coulter LS 13-320 Dual Wavelength Laser Particle Sizer, covering a size range from 0.4 to $2000 \mu \mathrm{m}$ and displayed as volume percent across 92 discrete size classes. Granulometric analyses were carried out in Excel using GRADISTAT version 8.0 (Blott, 2010), which calculates the standard granulometric statistics, textural descriptions and size fraction percentages. This showed that the particles in suspension were $\sim 47 \%$ silt and $\sim 43 \%$ very fine sand, and that this distribution did not change over time (Appendix one, Figure A1.2).

\subsubsection{Sponge responses}

Sponges were sampled during the experiment to measure respiration rates, feeding efficiency (particle clearance), assess morphological changes, and to evaluate the degree to which the sediments had infiltrated the animal (Figure 2.3). Sponge responses to the SSC treatments were assessed at different time points during the experiment: after 8, 23 and 30 days of suspended sediment (SS) exposure ( 1, 3 and 4 weeks, respectively; hereafter Day 8, Day 23, and Day 30 ), and after two weeks without SS ( $\sim 6$ weeks after addition to the chambers; hereafter Day 44). At each time point, a single sponge from each chamber was sacrificed to measure the responses listed above (Figure 2.3). At Day 44, $\mathrm{N}=14$ sponges were sampled as only 14 chambers contained live sponges.
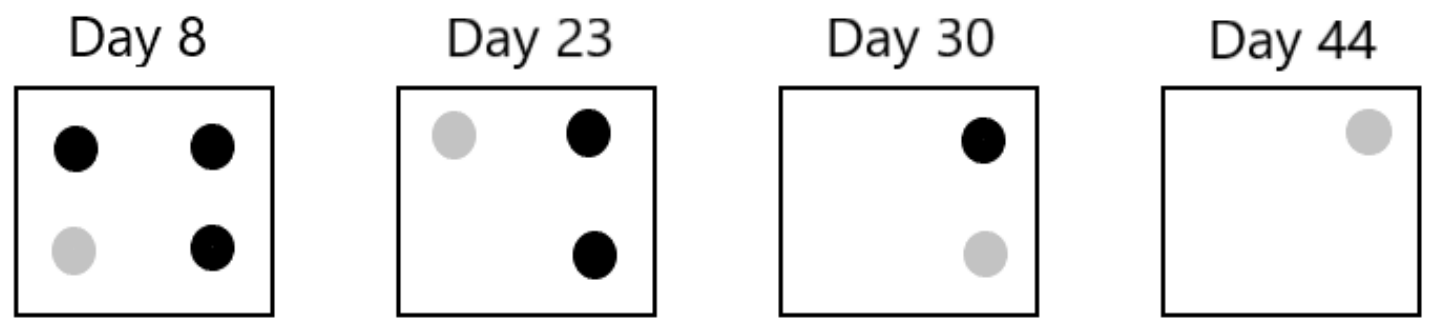

Figure 2.3. Schematic representation of the experimental sampling design. Each square represents a sediment chamber, dots represent sponge samples inside the chambers. Grey dots represent sponges sampled at each time point.

\subsubsection{Respiration rates}

Oxygen consumption rates were assessed at each sampling time point in sealed $75 \mathrm{ml}$ cylindrical Perspex respiration chambers with pre-calibrated PreSens oxygen sensor spots attached to their inner surface. Water temperature in the respiration chambers was the same as 
ambient water temperature. The sealed respiration chambers were placed in a flow-through water bath to maintain constant water temperature, and the water was gently stirred using a magnetic stir bar located in a separate compartment at the bottom of each chamber. Sponges were added to the respiration chambers and "dark-adapted" for $30 \mathrm{~min}$ to minimize the potential oxygen production by photosynthetic symbionts and to allow the sponge to recover from being moved into the chambers, before the chambers were sealed. The microbial community composition of $C$. incrustans has been previously described using $16 \mathrm{~S}$ sequencing (Astudillo Garcia, 2017), with a small proportion (approx. 5\%) of cyanobacterial sequences being reported. However, earlier Pulse Amplitude Modulation (PAM) fluorometry work on $C$. incrustans (Bell unpublished data) found no evidence for photosynthetic activity (very low measurements of quantum yield (Y) of photosystem II). Dark respiration measurements were used as a precaution, although it is unlikely these symbionts contribute significantly to the nutrition of $C$. incrustans. Dissolved Oxygen (DO) readings were taken immediately after sealing and 30 min later using an optical fiber system (FIBOX 4, Pre-SenseGmbH, Germany). This time period was based on preliminary trials, to ensure oxygen levels did not drop below $75 \%$. Blank incubations $(\mathrm{N}=4)$ containing only seawater were used to correct for any microbial community respiration in the seawater. Blank values were used to correct actual respiration rates records, prior to standardize them for the sponge weight. Respiration rates (mg $\mathrm{O}_{2} \mathrm{l}^{-1} \mathrm{~h}^{-1} \mathrm{~g}(\mathrm{AFDW})^{-1}$ ) were determined after adjusting for the volume of water in the chamber and the sponge ash free dry weight (AFDW; after drying for $48 \mathrm{~h}$ at $60{ }^{\circ} \mathrm{C}$ to determine dry weight, followed by ashing at $500{ }^{\circ} \mathrm{C}$ for $5 \mathrm{~h}$ ). Because of the elevated water turbidity inside the chambers with SSCs $>25 \mathrm{mg}^{-1}$, it was not possible to visually assess, with fluorescein dye, if sponges were actively pumping prior to sampling.

\subsubsection{Morphology}

Photographs of all sponges were taken immediately prior to the experiment start (Day 0), and of each sponge on the day it was removed from the chamber (Day 8, Day 23 or Day 44), using a Nikon D850 camera. Comparisons between images taken at Day 0 and at each following sampling time point were used to assess changes in the appearance of each sponge during the experiment. Each sponge was then sectioned (transversely) and photographs were taken of the internal surfaces. A scale and colour bar were included in each image, and analyses were conducted using ImageJ. During the experiment some sponges grew projections on their dorsal surfaces, which are referred as "fistules" from here on. These irregular shaped growths were 
often observed growing through layers of sediment that had accumulated on the sponge surface. The number of fistules on each sponge was quantified using the images, and is presented as a portion of the sponge surface area (fistules $\mathrm{cm}^{-2}$ ).

\subsubsection{Feeding efficiency}

Sponge feeding efficiency was assessed at each sampling time point in 11 cylindrical 'feeding chambers'. Each sponge $(\mathrm{N}=16)$ was added to the feeding chamber and left acclimating for 30 minutes. Cylindrical feeding chambers, filled with $700 \mathrm{ml}$ of fresh seawater, were placed in a flow-through water bath to maintain constant water temperature, and water mixing was achieved using a magnetic stir bar located in a separate compartment at the bottom of each chamber. After acclimation, $0.01 \mathrm{ml}$ of Nanno $3600^{\mathrm{TM}}$ diet was added to each feeding chamber. Water samples $(1 \mathrm{ml})$ were sampled from each feeding chamber two minutes $\left(\mathrm{T}_{0}\right)$ and one hour ( $\mathrm{T}_{\text {end }}$ ) after algae were added. Water samples were fixed in formalin and stored at $-80{ }^{\circ} \mathrm{C}$ until flow cytometric analysis could be performed. In preparation for flow cytometric analysis, samples were thawed to room temperature.

To quantify the number of particles, water samples were analyzed with a four Laser (16 Violet [405 nm] channels, 14 Blue [488 nm] channels, 10 Yellow/Green [561 nm] channels, 8 Red [640 nm] channels) Cytek ${ }^{\circledR}$ Aurora cytometer at the Malaghan Institute of Medical Research in Wellington. Forward Scattered Light (FSC) was collected using a photodiode and Side Scattered Light (SSC) was collected using a multi-channel narrow-beam detector array. Background noise was determined by running seawater samples $(0.1 \mu \mathrm{m}$ filtered $)$ through the cytometer to set an appropriate threshold and aid gating of the paticles of interest (Nannochloropsis spp. cells, 1-2 $\mu \mathrm{m}$ diameter). Cells were identified for their emitted fluorescence, which was detected by the Yellow/Green laser (channel YG5, wavelength detected: $669-687 \mu \mathrm{m}$ ) of the cytometer. Flow cytometry analysis was performed in FlowJo Software (version 10.4.2; Tree-Star, Ashland, OR), and data were presented using log-scale pseudo-colour dot plots for all parameters (SSC-A, FSC-A, yellow/green fluorescence). The total number of particles in each $\mathrm{ml}$ of water were calculated using the formula:

$$
\mathrm{P}_{\mathrm{tot}}=\left(\mathrm{P}_{\mathrm{s}} * \mathrm{~V}_{\mathrm{end}}\right) / \mathrm{V}_{\mathrm{s}}
$$

where $\mathrm{P}_{\text {tot }}$ is the total number of particles, $\mathrm{P}_{\mathrm{s}}$ is number of particles subsampled, $\mathrm{V}_{\text {end }}$ is the final volume, and $\mathrm{V}_{\mathrm{s}}$ is the volume subsampled by the cytometer. 
Sponge clearance efficiency was evaluated by calculating the difference of particles between $\mathrm{T}_{0}$ and $\mathrm{T}_{\text {end }}$, and by normalizing this value per sponge AFDW, and expressed as particle count $\mathrm{h}^{-1} \mathrm{ml}^{-1} \mathrm{~g}(\mathrm{AFDW})^{-1}$.

\subsubsection{Statistical analysis}

The effects of SSC treatment and time (8, 23, 30 and 44 days), with interactions, on sponge responses (respiration rates, number of fistules $\mathrm{cm}^{-2}$ and particles clearance) were tested with a general linear model (GLM). "SSC treatment" was used as a continuous variable and "time" as a fixed factor. Equal variance and normal distribution assumptions were tested via analysis of the residual distribution plots and residual vs predicted values, and with the Shapiro-Wilk test, respectively. Particle retention data were square-root transformed to meet the normality of the residuals assumption. Dead sponges were excluded from statistical analyses. For particle clearance efficiency, data were excluded from the statistical analysis when the particle clearance was negative. To evaluate if the difference between particles count at $\mathrm{T}_{0}$ and $\mathrm{T}_{\text {end }}$ was significant, a Wilcoxon paired Signed-Rank Test was performed. Statistical analyses and plots were conducted in $\mathrm{R}$ version 3.6.3 (R Core Team, 2020).

\subsection{Results}

\subsubsection{Survival}

There were four deaths across all of the SSC treatments during the six week experiment, three on Day 23 (from chambers with SSC levels of 96, 170 and $389 \mathrm{mg} \mathrm{l}^{-1}$ ), and one on Day 30 (in the $288 \mathrm{mg} \mathrm{l}^{-1} \mathrm{SSC}$ chamber). The two dead sponges from the 96 and $389 \mathrm{mg}^{-1} \mathrm{SSCs}$ on Day 23 had originated from the same clone, so it is possible they were compromised during the preexperiment sectioning, or that this sponge was unhealthy at the onset of the experiment.

\subsubsection{Respiration rates}

Respiration rates were variable between sponges $\left(0.1-0.8 \mathrm{mg} \mathrm{O}_{2} \mathrm{l}^{-1} \mathrm{~h}^{-1} \mathrm{~g}\right.$ (AFDW) ${ }^{-1}$; Figure 2.4). There was a slight negative relationship between respiration rate and SSC, which was strongest on Day $23\left(\mathrm{R}^{2}=0.1016\right.$; Figure $\left.2.4 \mathrm{~B}\right)$ and at the end of the two-week recovery period in ambient seawater (Day $44 \mathrm{R}^{2}=0.1217$; Figure 2.4D). This relationship was not detected as statistically significant using two way ANOVA $\left(\operatorname{SSC~F}_{(1,52)}=2.53, \mathrm{p}=0.1178\right.$; Table 2.1A). 
Table 2.1. ANOVA table and summary of General Linear Model tests investigating the effects of SSCs on Crella incrustans respiration rates (A) number of fistules (B) and feeding efficiency (C). $\mathrm{DF}=$ degrees of freedom; $\mathrm{SS}=$ sum of squares; $\mathrm{MS}=$ mean square. Significant values are shown in bold.

\begin{tabular}{lrrrrr}
\hline & DF & SS & MS & F-value & Pr>F \\
\hline A) Respiration rates & & & & & \\
\hline SSC & 1 & 0.064 & 0.064 & 2.53 & 0.1178 \\
Day & 3 & 0.027 & 0.009 & 0.35 & 0.7881 \\
SSC Day & 3 & 0.063 & 0.021 & 0.83 & 0.4808 \\
Residuals & 52 & 1.311 & 0.025 & & \\
\hline B) Number of fistules & & & & & \\
\hline SSC & 1 & 8.622 & 8.622 & 7.77 & 0.0074 \\
Day & 3 & 2.651 & 0.883 & 0.8 & 0.5017 \\
SSC*Day & 3 & 3.26 & 1.087 & 0.98 & 0.4099 \\
Residuals & 52 & 57.734 & 1.11 & & \\
\hline C) Particle clearance & & & & & \\
\hline SSC & 1 & 2929 & 2929 & 0.05 & 0.8164 \\
Day & 3 & 417919 & 139306 & 2.60 & 0.0692 \\
SSC*Day & 3 & 359454 & 119818 & 2.24 & 0.1029 \\
& & 165583 & & & \\
Residuals & 31 & 8 & 53414 & & \\
\hline
\end{tabular}
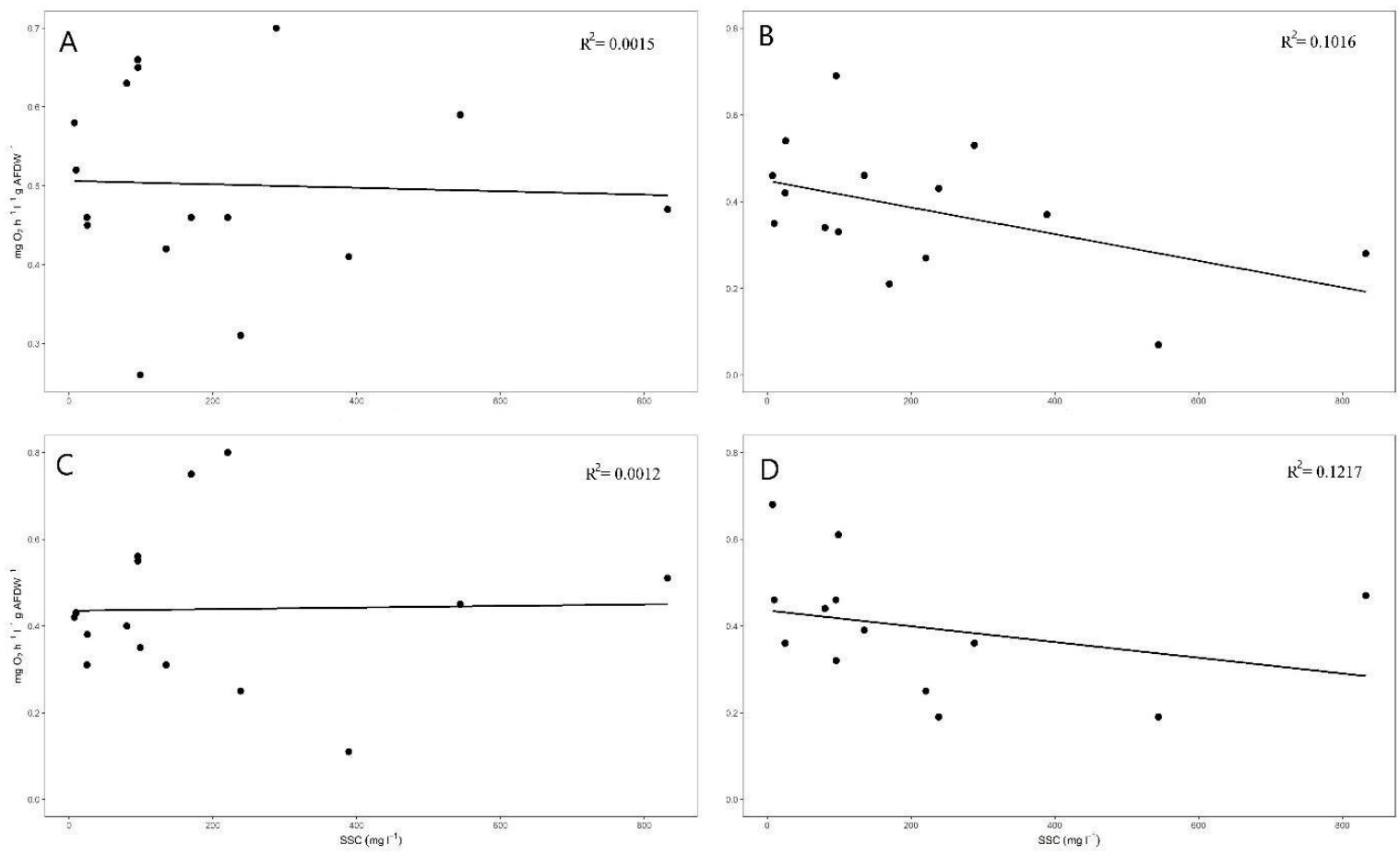
Figure 2.4. Respiration rates of Crella incrustans after 8 (A), 23 (B), 30 (C) days of sediment exposure and after a two-week recovery period in ambient seawater (D). Best fit lines and $\mathrm{R}^{2}$ values for the relationship with SSCs at each time point are shown.

\subsubsection{Morphology}

Sponges developed fistules over the course of the experiment (Figures 2.5 and 2.6). At Day 0, no sponge had fistules. Control sponges had $<1$ fistule $\mathrm{cm}^{-2}$ at Days 8, 23 and 44 (Figure 2.5). In all other treatments, the number of fistules increased after Day 8. There was a positive relationship between fistule abundance and SSCs, although the variation indicated by $\mathrm{R}^{2}$ values were low (Figure 2.5). This relationship was statistically significant across all sampling days $\left(\operatorname{SSC~} \mathrm{F}_{(1,52)}=7.77, \mathrm{p}=0.0074 ;\right.$ Table 2.1B $)$.
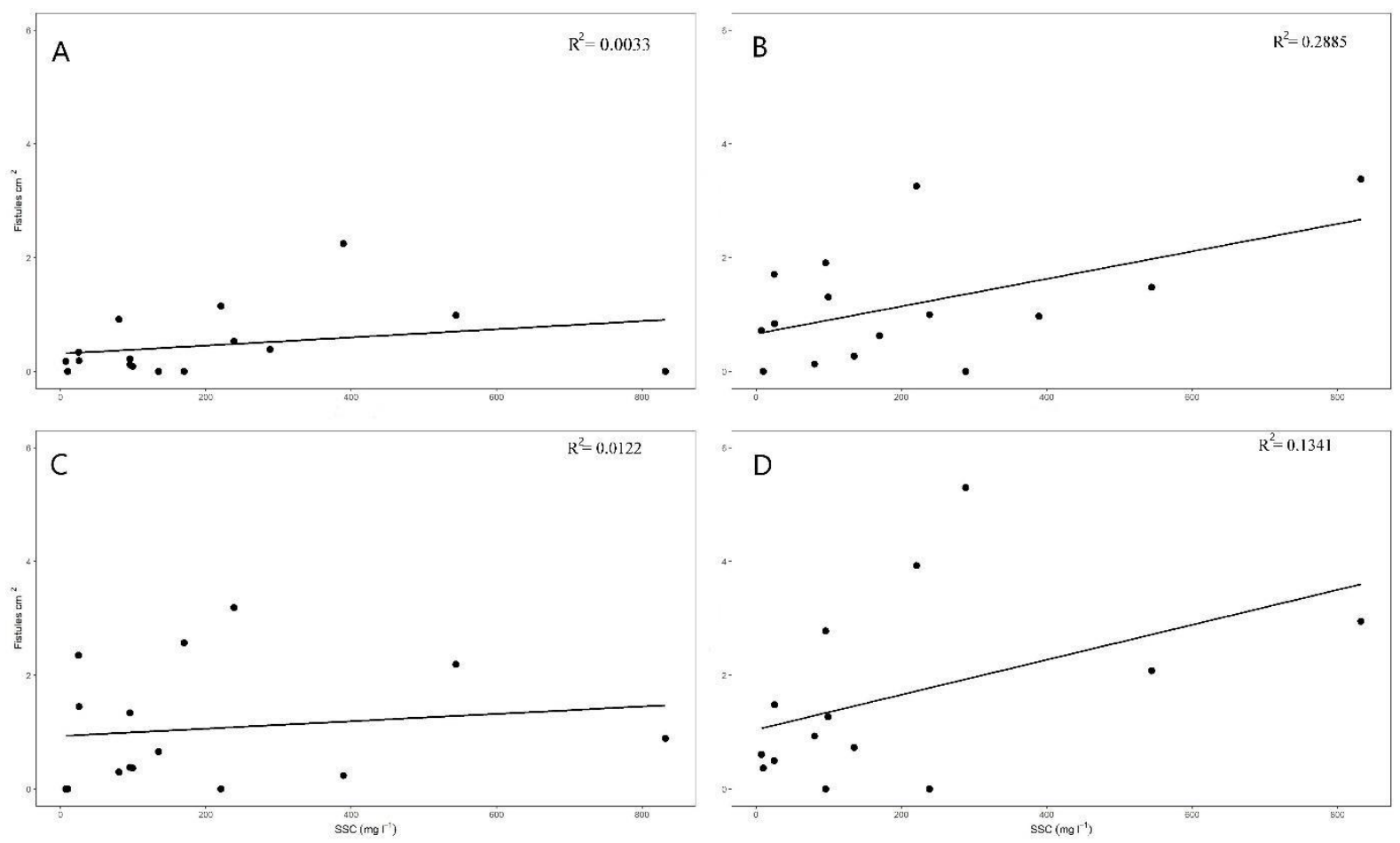

Figure 2.5. Number of fistules $\mathrm{cm}^{-2}$ on the surface of sponges sampled after 8 (A), 23 (B), 30 (C) days of sediment exposure and after a two-week recovery period in ambient seawater (D). Best fit lines and $\mathrm{R}^{2}$ values for the relationship with SSCs are shown. 


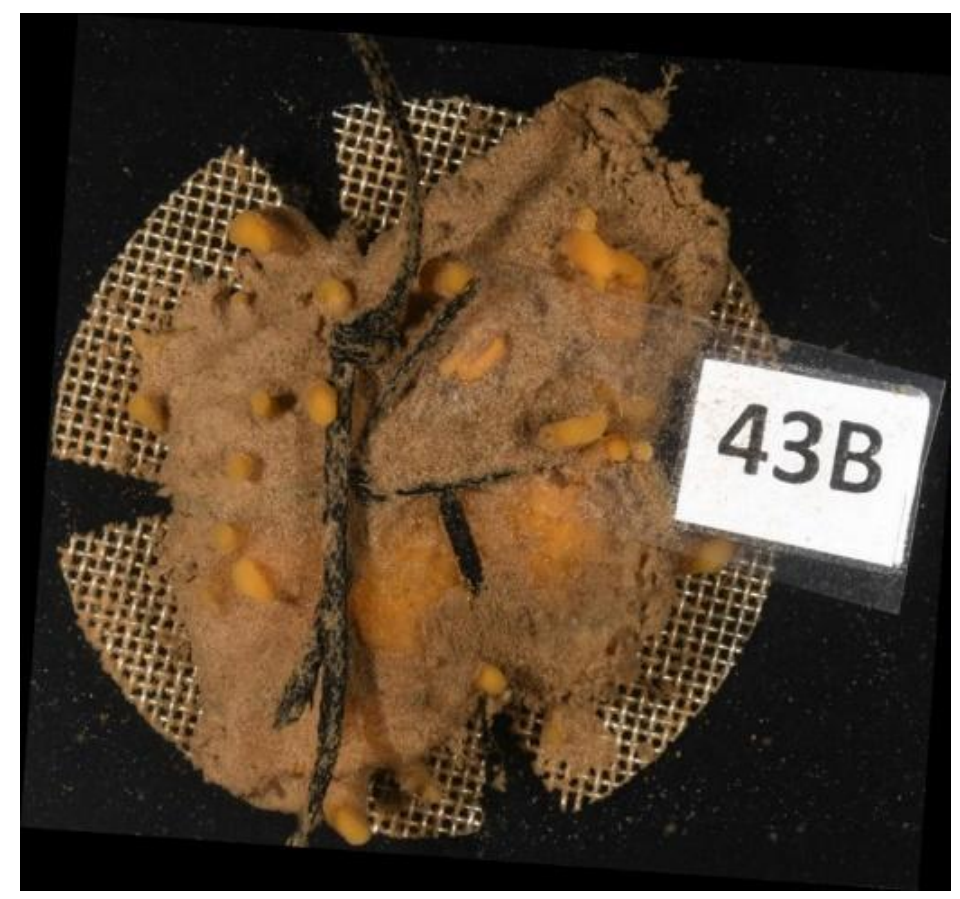

Figure 2.6. Image of the surface of a sponge after 30 days exposure to SSC of $170 \mathrm{mg}^{-1}$, showing fistules protruding from sediment that had settled on the sponge surface.

Dissections revealed internal sediment accumulation in many sponges (Figure 2.7). Qualitative visual assessments showed internal sediment had already built up after eight days of exposure (Figure 2.7), when half of the sponges in the elevated SSC chambers contained sediments, including those from the four highest levels. On Days 23 and 30, sediment was visible in all sponges exposed to elevated SSCs, with one exception (99 $\mathrm{mg} \mathrm{l}^{-1} \mathrm{SSC}$ on Day 30). No sediment was observed in control sponges. The magnitude of this sediment incursion was variable, regardless of SCC treatment (Figure 2.7). At the Day 44 time point, after two weeks in ambient seawater, two thirds of sponges still contained sediments; those that were 'sediment free' included sponges from the two lowest SSCs, and one each from the 96 and $221 \mathrm{mg} \mathrm{l}^{-1} \mathrm{SSC}$ chambers. 


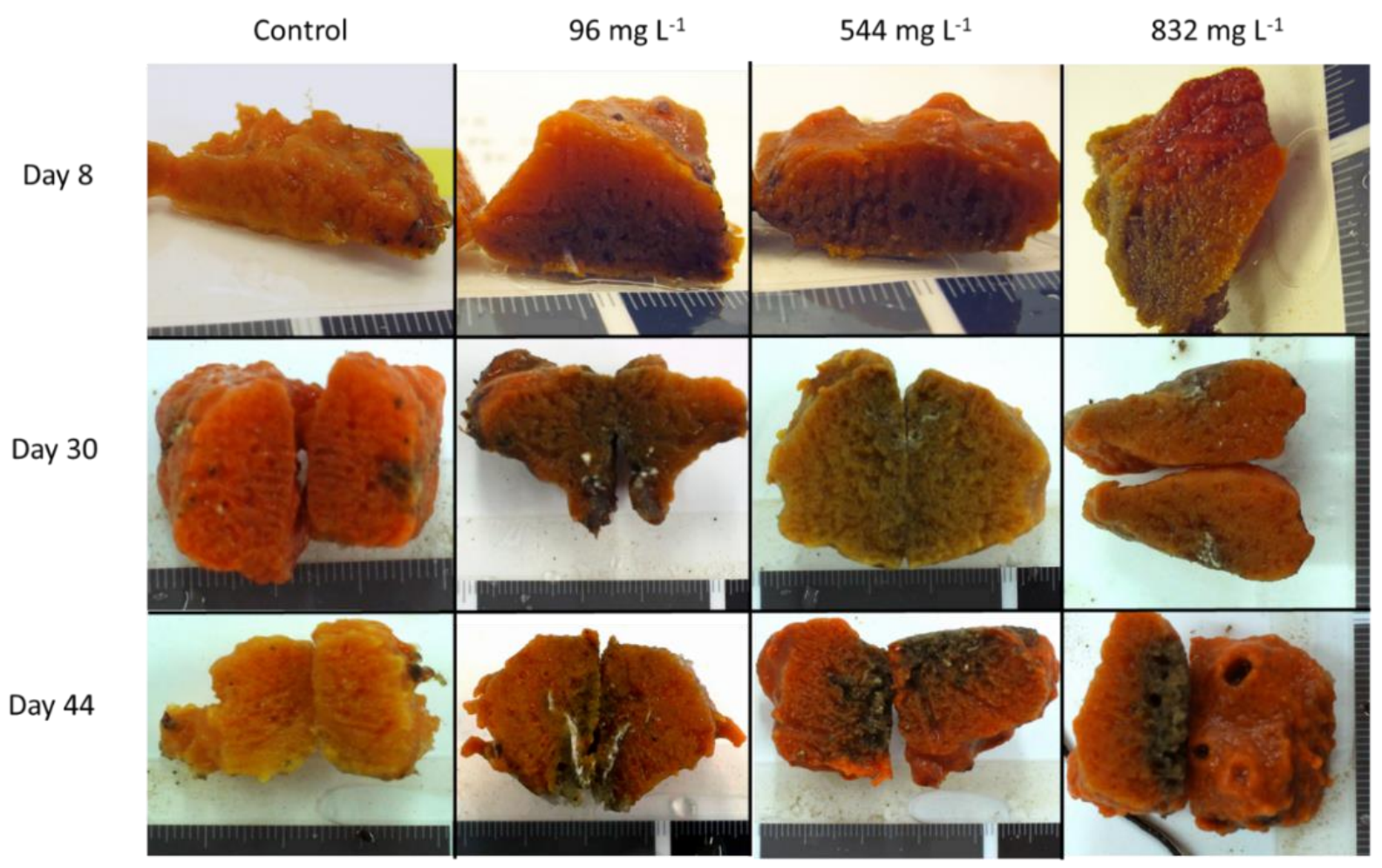

Figure 2.7. Images of cross-sectioned sponges showing the accumulation of sediments. Examples are shown of control and sediment-exposed sponges after 8 days and 30 days, and at 44 days.

\subsubsection{Feeding efficiency}

In $32 \%$ of the samples the number of particles detected at $\mathrm{T}_{\text {end }}$ (i.e. at the end of the sponge feeding incubation period) was higher than the number of particles detected at $\mathrm{T}_{0}$ (i.e. at the beginning of the sponge feeding incubation period). The average particle rentention was 12.9 $\pm 15.7 \% \mathrm{ml}^{-1}$ (mean $\pm \mathrm{SD}$ ). The Wilcoxon paired Signed-Rank Test showed that the cell count at $\mathrm{T}_{0}$ and $\mathrm{T}_{\text {end }}$ was not significantly different $(\mathrm{z}=-1.62, \mathrm{p}=0.1)$. Sponge particle retention was variable $\left(4 \times 10^{3}-1 \times 10^{6}\right.$ cells h$^{-1} \mathrm{ml}^{-1} \mathrm{~g}(\mathrm{AFDW})^{-1}$, Figure 2.8) and there was no correlation between sponge particle clearance and SSCs $\left(\mathrm{F}_{(1,31)}=0.05, \mathrm{p}=0.81\right)$, or between particle clearance and time $\left(\mathrm{F}_{(3,31)}=2.60, \mathrm{p}=0.069\right)$. 

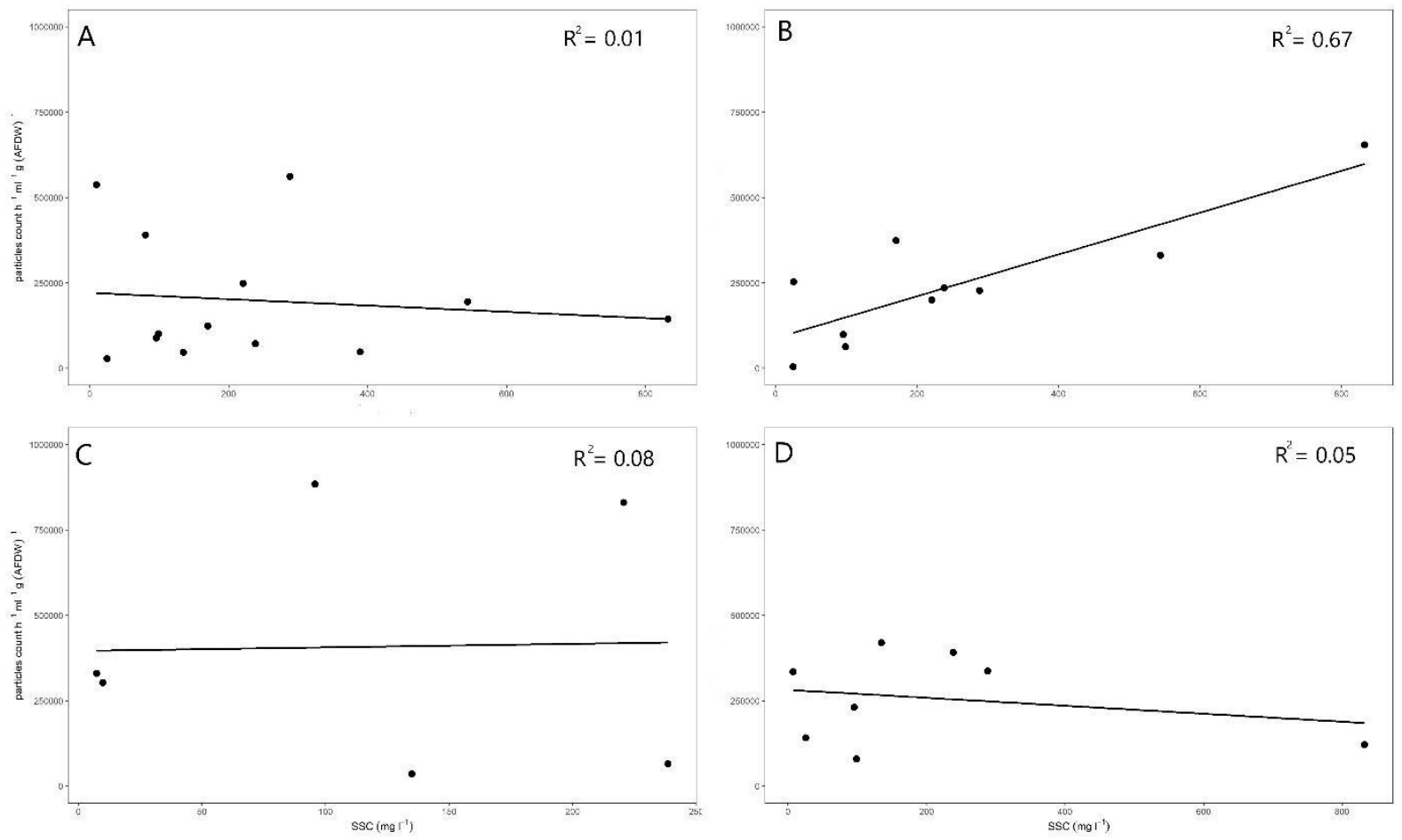

Figure 2.8. Particle retention by $C$. incrustans after 8 (A), 23 (B), 30 (C) days of sediment exposure and after two-week recovery period in ambient seawater (D). Best fit lines are shown and $\mathrm{R}^{2}$ values for the relationships with SSCs at each time point are shown.

\subsection{Discussion}

This study has provided new information on the effect of elevated SSCs on a common and widely distributed coastal New Zealand sponge, $C$. incrustans. Survival was high during the four week-long exposure to elevated SSCs, even at the highest concentration (832 $\mathrm{mg}^{-1}$ ). There was considerable variation in responses amongst sponges, and no strong negative effects were detected, even at the highest SSCs.

\subsubsection{Respiration rates}

There was no significant effect of increased SSC on sponge respiration rates. In constrast, several previous studies have reported significant effects of elevated SSCs on sponge respiration from much shorter exposure periods (Tjensvoll et al., 2013; Kutti et al., 2015). In addition, in situ reductions in pumping rates have been reported in response to storm generated turbidity for some tropical sponge species (Reiswig, 1971). The lack of strong effect of elevated SSC on C. incrustans respiration rates is consistent with a recent study by Grant et al. (2019) 
who noted no change in pumping rates in one glass sponge species in response to sediments. The lack of effects on respiration in this experiment is surprising, since the sponges were accumulating sediment internally, which might be expected to compromise sponge pumping efficiency. C. incrustans appears to have limited loss of metabolic function in response to the SSCs tested. Unfortunately, it is not possible to directly compare the actual respiration rates from this experiment with those of the other studies on sponge sediment impacts because of differences in the way respiration rates are standardized between studies. However, Bates et al. (2018) examined the effects of different $\mathrm{pH}$ treatments on $C$. incrustans and found similar respiration rates for their control sponges as the ones reported in this study (assuming an AFDW to DW ratio of 50-65\%), which provides further support for the limited effect of elevated SSCs on the respiration rate of this species.

\subsubsection{Morphology}

Fistules were noted during the experiment in many $C$. incrustans with their numbers positively correlated with SSC. Sponges living in soft sediment environments often have apical fistular structures that protrude upwards, ensuring some of the sponge is elevated above the sediment (Schönberg, 2016). These elevated structures have been reported to be where the water is inhaled into the sponge (see Rützler, 1997). While fistules have been reported for many sponge species living in sediments and also for some hard substratum species (e.g. Polymastia spp. at Lough Hyne; Bell pers. obs.), to my knowledge this is the first report of such structures being produced during a sediment experiment. The production of fistules in $C$. incrustans has never been observed at its field collection site (Bell pers. obs.). The generation of fistules in this experiment may be a natural adaptation strategy in response to sediment that had settled on the sponge surface rather than to increased SSCs. This morphological change could potentially be the result of remodeling of the sponge body plan to move the inhalant pores to a higher position than the main sponge surface, enabling it to continue to pump water. Alternatively, the buildup of sediment internally may have promoted fistule production.

The qualitative observations of accumulated internal sediment in C. incrustans suggest it may take longer than two weeks for sediment removal, with several sponges showing internal sediments after two weeks' recovery. A similar, variable response was noted for Ianthella basta after two weeks in control conditions, although internal sediment had decreased to a very low level (Strehlow et al., 2017). Some sponges are known to take up and incorporate sediments 
into their body and in some species, incorporation of sediment in their tissues is beneficial and can actually enhance growth and provide structural support (Schönberg, 2016, and references therein). However, previous experiments and taxonomic work with C. incrustans (Berman and Bell, 2010) have not noted any internal sediment in specimens from the field.

\subsubsection{Feeding efficiency}

As sponges pump large volumes of water and retain food particles, it is thought that suspended sediments can cause a reduction in the ability of sponges to feed as a consequence of reducing pumping rates to prevent clogging of their filtration system (Bell et al., 2015). A study conducted on the New Zealand sponge Aaptos spp. (Lohrer et al., 2006) demonstrated that feeding efficiency in this sponge species was reduced following exposure to terrigenous sediments.

In this Chapter, the high variability in particle retention among $C$. incrustans samples, irrespective of the SSC treatments, prevented detection of whether $C$. incrustans feeding efficiency was compromised by SSC. Particle retention in this study was low (12.9 $\pm 15.7 \%$

cells $\mathrm{ml}^{-1}$ ) compared to that reported for $C$. incrustans in situ, which ranges from $\sim 40 \%$ to $>90 \% \mathrm{ml}^{-1}$ (Perea-Blázquez et al., 2013).

Negative retention rates in suspension feeder organisms have been previously documented: in sponges in situ (Perea-Blázquez et al., 2011), and more often in bivalves in laboratory experiments (Vahl, 1972; Møhlenberg \& Riisgård, 1978; Riisgård, 1988; te Velde, 2018). Te Velde (2018) hypothesized that the negative retention rates observed in Mytilus edulis were due to a lack of proper mixing of the algae particles in the feeding chambers, while Riisgård (1988) stated that the negative retention rates he observed in six bivalve species were due to particles $(2$ to $3 \mu \mathrm{m})$ produced by the bivalves.

Given the high retention rates observed in C. incrustans by Perea-Blázquez et al. (2013), the lack of significant difference in the particles count in my experiment between $\mathrm{T}_{0}$ and $\mathrm{T}_{\text {end }}$ might suggest that $C$. incrustans was not actively pumping during the 'feeding incubation' period of my experiment. However, it cannot be excluded that $C$. incrustans may have produced cells during the incubation time, just as Riisgård (1988) observed in bivalves, which could have compromised the particles count and explain the negative retention rates. 


\subsubsection{Tolerance of coastal temperate sponges to sediment}

The SSCs used in this study are high compared to those used in most previous experiments on sponges (see Bell et al., 2015; Schönberg, 2016) and likely represent conditions expected under major seafloor disturbance (e.g. extreme storms, mining or trawling; De Madron et al., 2005; Bradshaw et al., 2012). Despite this, there was no strong evidence for negative impacts of elevated SSCs on C. incrustans, nor did the thin film of sediment that settled on the surface of the sponge appear to have detrimental effects. These results, combined with reports of dense sponge assemblages in other temperate regions that experience high SSCs and settled sediment (see Bell \& Barnes, 2000), support the view that shallow temperate sponges may be able to tolerate high levels of suspended sediment, and that sensitivity of sponge species to SSCs is likely influenced by pre-adaptation to the turbidity of the natural habitat (e.g. Abdul Wahab et al., 2017; Grant et al., 2019). However, the properties of the disturbed sediment are also important, as shown by the detrimental effects of terrestrial sediments (with predominantly clay-silt particle size composition and very low pH) on Aoptos spp. (Lohrer et al., 2006) and Tethya burtoni (Schwarz et al., 2006).

\subsection{Conclusions}

Elevated SSCs do not appear to have strong effects on the physiology of the common New Zealand sponge $C$. incrustans, at least over the time frame of this experiment. There were morphological changes, with the development of apical fistules that may be an adaptation to the sediment settling on their external surfaces, or accumulating internally, during the experiment. Sediment was taken up by $C$. incrustans, but the species has mechanisms to clear the sediment once the source of SSC is removed. I conclude that the coastal environments that these sponges live in may predispose them to coping with high SSCs, and that they may also be tolerant of sediment deposition events that temporarily cover their surfaces. 


\section{References}

Abdul Wahab M.A., Fromont, J., Gomez, O, Fisher, R., Jones, R. (2017). Comparisons of benthic filter feeder communities before and after a large-scale capital dredging program. Marine Pollution Bulletin, 122, 176-193.

Airoldi, L. (2003). The effects of sedimentation on rocky coast assemblages. Oceanography and Marine Biology: an Annual Review, 41, 161-236.

Astudillo Garcia, M.D.C. (2017). Microbiology of marine sponges: From community structure to symbiont function. $\mathrm{PhD}$ thesis. The University of Auckland, New Zealand. http://hdl.handle.net/2292/36039.

Bannister, R.J., Battershill, C.N., De Nys, R. (2012). Suspended sediment grain size and mineralogy across the continental shelf of the Great Barrier Reef: Impacts on the physiology of a coral reef sponge. Continental Shelf Research, 32, 86-95.

Bates, T.E., Bell, J.J. (2018). Responses of two temperate sponge species to ocean acidification. New Zealand Journal of Marine and Freshwater Research, 52, 247-263.

Bell, J.J. (2004). Evidence for morphology-induced sediment settlement prevention on the tubular sponge Haliclona urceolus. Marine Biology, 146, 29-38.

Bell, J.J. (2008). The functional roles of marine sponges. Estuarine, Coastal and Shelf Science, $79,341-353$.

Bell, J.J., \& Barnes, D.K. (2000). The distribution and prevalence of sponges in relation to environmental gradients within a temperate sea lough: inclined cliff surfaces. Diversity and Distributions 6, 305-323.

Bell, J.J., McGrath, E., Biggerstaff, A., Bates, T., Bennett, H., Marlow, J., Shaffer, M. (2015). Sediment impacts on marine sponges. Marine Pollution Bulletin, 94, 5-13.

Bennett, H.M., Altenrath, C., Woods, L., Davy, S.K., Webster, N.S., Bell, J.J. (2017). Interactive effects of temperature and $\mathrm{pCO}_{2}$ on sponges: from the cradle to the grave. Global Change Biology, 23, 2031-2046.

Berman, J., Bell, J.J. (2010). Spatial variability of sponge assemblages on the Wellington South Coast, New Zealand. Open Marine Biology Journal, 4, 12-25. 
Biggerstaff, A., Smith, D.J., Jompa, J., Bell, J.J. (2017). Metabolic responses of a phototrophic sponge to sedimentation supports transitions to sponge-dominated reefs. Scientific Reports, 7, 2725 .

Blott, S.J. (2010) GRADISTAT ver. 8.0: A grain size distribution and statistics package for the analysis of unconsolidated sediments by sieving or laser granulometer. Kenneth Pye Associates Ltd, UK (www.kpal.co.uk/gradistat.html)

Bradshaw, C., Tjensvoll, I., Sköld, M., Allan, I.J., Molvaer, J., Magnusson, J., Naes, K., Nilsson, H. C. (2012). Bottom trawling resuspends sediment and releases bioavailable contaminants in a polluted fjord. Environmental Pollution, 170, 232-241.

Capuzzo, J.M., Burt, W.V., Duedall, I.W., Park, P.K., Kester, D.R. (1985). The impact of waste disposal in nearshore environments. In: Wastes in the ocean. Volume 6. Nearshore waste disposal, B.H. Ketchum et al. (eds). New York: John Wiley, 3-38.

Carballo, J.L. (2006). Effect of natural sedimentation on the structure of tropical rocky sponge assemblages. Ecoscience, 13, 119-130.

Cheung, S.G., Shin, P.K.S. (2005). Size effects of suspended particles on gill damage in greenlipped mussel Perna viridis. Marine Pollution Bulletin, 51, 801-810.

Crain, C.M., Halpern, B.S., Beck, M.W., Kappel, C.V. (2009). Understanding and managing human threats to the coastal marine environment. Annals of the New York Academy of Sciences, 1162, 39-62.

Cussioli, M.C., Bryan, K.R. Pilditch, C.A. de Lange, W.P., Bischof, K. (2019). Light penetration in a temperate meso-tidal lagoon: Implications for seagrass growth and dredging in Tauranga Harbour, New Zealand. Ocean and Coastal Management, 174, 25-37.

Davies, A.J., Last, K.S., Attard, K., Hendrick, V.J. (2009). Maintaining turbidity and current flow in laboratory aquarium studies, a case study using Sabellaria spinulosa. Journal of Experimental Marine Biology and Ecology, 370, 35-40.

De Madron, X.D., Ferré, B., Le Corre, G., Grenz, C., Conan, P., Pujo-Pay, M., Buscail, R., Bodiot, O. (2005). Trawling-induced resuspension and dispersal of muddy sediments and dissolved elements in the Gulf of Lion (NW Mediterranean). Continental Shelf Research, 25, 2387-2409. 
Ellis, J.I., Clark, M.R., Rouse, H.L., Lamarche, G. (2017). Environmental management frameworks for offshore mining: the New Zealand approach. Marine Policy, 84, 178-192.

Ellis, J., Cummings, V., Hewitt, S., Thrush, S., Norkko, A. (2002). Determining effects of suspended sediment on condition of a suspending feeding bivalve (Atrina zelandica): results of a survey, a laboratory experiment and a field transplant experiment. Journal of Experimental Marine Biology and Ecology, 267, 147-174.

Erftemeijer, P.L., Riegl, B., Hoeksema, B.W., Todd, P.A. (2012). Environmental impacts of dredging and other sediment disturbances on corals: a review. Marine Pollution Bulletin, 64, $1737-1765$.

Fabricius, K.E. (2005). Effects of terrestrial runoff on the ecology of corals and coral reefs: review and synthesis. Marine Pollution Bulletin, 50, 125-146.

Fahey, B.D., Coker, R.J. (1992). Sediment production from forest roads in Queen Charlotte forest and potential impact on marine water quality, Marlborough Sounds, New Zealand. New Zealand Journal of Marine and Freshwater Research, 26, 187-195.

Fisher, R., Stark, C., Ridd, P., Jones, R. (2015). Spatial patterns in water quality changes during dredging in tropical environments. PLoS ONE, 10: e0143309.

Gerrodette, T., Flechsig, A.O. (1979). Sediment-induced reduction in the pumping rate of the tropical sponge Verongia lacunosa. Marine Biology, 55, 103-110.

Grant, N., Matveev, E., Kahn, A.S., Leys, S.P. (2018). Suspended sediment causes feeding current arrests in situ in the glass sponge Aphrocallistes vastus. Marine Environmental Research, 137, 111-120.

Grant, N., Matveev, E., Kahn, A.S., Archer, S.K. Dunham, A., Bannister, R.J., EerkesMedrano, D., Leys, S.P. (2019). Effect of suspended sediments on the pumping rates of three species of glass sponge in situ. Marine Ecology Progress Series, 615, 79-100.

Halpern, B.S., Frazier, M., Potapenko, J., Casey, K.S., Koenig, K., Longo, C., Lowndes, J.S., Rockwood, C.R., Selig, E.R., Selkoe, K.A, Walbridge, S. (2015). Spatial and temporal changes in cumulative human impacts on the world's ocean. Nature Communications, 6, 7615.

Hewitt, J.E., \& Norkko, J.T. (2007). Incorporating temporal variability of stressors into studies: An example using suspension-feeding bivalves and elevated suspended sediment concentrations. Journal of Experimental Marine Biology and Ecology, 341, 131-141. 
Jones, R., Fisher, R., Bessell-Browne, P. (2019). Sediment deposition and coral smothering. PLoS ONE 14: e0216248.

Kelly, M., Edwards, A.R., Wilkinson, M.R., Alvarez, B., Cook, S. de C., Bergquist, P.R., Buckeridge, J.S., Campbell, H.J., Reiswig, H.M., Valentine, C., Vacelet, J. (2009). Phylum Porifera - sponges. New Zealand Inventory of Biodiversity 1. Canterbury University Press: 2346.

Knapp, I.S.S., Williams, G.J., Carballo, J.L., Cruz-Barraza, J.A., Gardner, J.P.A., Bell, J.J. (2013). Restriction of sponges to an atoll lagoon as a result of reduced environmental quality. Marine Pollution Bulletin, 66, 209-220.

Kreyling, J., Schweiger, A.H., Bahn, M., Ineson, P., Migliavacca, M., Morel-Journel, T., Christiansen, J.R., Schtickzelle, N. and Larsen, K.S. (2018). To replicate, or not to replicatethat is the question: how to tackle nonlinear responses in ecological experiments. Ecology Letters, 21, 1629-1638.

Kutti, T., Bannister, R.J., Fosså, J.H., Krogness, C.M., Tjensvoll, I., Søvik, G. (2015). Metabolic responses of the deep-water sponge Geodia barretti to suspended bottom sediment, simulated mine tailings and drill cuttings. Journal of Experimental Marine Biology and Ecology, 473, 64-72.

Larcombe P., Ridd P.V., Prytz A., Wilson B. (1995). Factors controlling suspended sediment on inner-shelf coral reefs, Townsville, Australia. Coral Reefs, 14, 163-171.

Law, C.S., Rickard, G.J., Mikaloff-Fletcher, S.E., Pinkerton, M.H., Behrens, E., Chiswell, S. M., Currie, K. (2018). Climate change projections for the surface ocean around New Zealand. New Zealand Journal of Marine and Freshwater Research, doi: $10.1080 / 00288330.2017 .1390772$

Levin, L.A., Mengerink, K., Gjerde, K.M., Rowden, A.A., Van Dover, C.L., Clark, M.R., Ramirez-Llodra, E., Currie, B., Smith, C.R., Sato, K.N., Gallo, N., Sweetman A.K., Lily H., Armstrong, C.W., Brider, J. (2016). Defining "serious harm" to the marine environment in the context of deep-seabed mining. Marine Policy, 74, 245-259.

Leys, S.P., Mackie, G.O., Meech, R.W. (1999). Impulse conduction in a sponge. Journal of Experimental Biology, 202, 1139-1150. 
Leys, S.P., Wilson, K., Holeton, C., Reiswig, H.M., Austin, W.C., Tunnicliffe, V. (2004). Patterns of glass sponge (Porifera, Hexactinellida) distribution in coastal waters of British Columbia, Canada. Marine Ecology Progress Series, 283, 133-149.

Lohrer, A.M., Hewitt, J.E., Thrush, S.F. (2006). Assessing far-field effects of terrigenous sediment loading in the coastal marine environment. Marine Ecology Progress Series, 315, $13-18$

Maldonado, M., Aguilar, R., Bannister, R.J., Bell, J.J., Conway, K.W., Dayton, P.K., Leys, S. P. (2017). Sponge grounds as key marine habitats: a synthetic review of types, structure, functional roles, and conservation concerns. In Marine Animal Forests, Volume 1: The Ecology of Benthic Biodiversity Hotspots. Rossi, S., Bramanti, L., Gori, A., Orejas Saco del Valle, C. (Eds): pp. 145-183.

Maldonado, M., Giraud, K., Carmona, C. (2008). Effects of sediment on the survival of asexually produced sponge recruits. Marine Biology, 154, 631-641.

McGrath, E.C., Smith, D.J., Jompa, J., Bell, J.J. (2017). Adaptive mechanisms and physiological effects of suspended and settled sediment on barrel sponges. Journal of Experimental Marine Biology and Ecology, 496, 74-83.

Ministry for the Environment and Statistics New Zealand (2015). New Zealand's Environmental Reporting Series: Environment Aotearoa 2015. Available from www.mfe.govt.nz.

Møhlenberg, F., Riisgård, H.U. (1978). Efficiency of particle retention in 13 species of suspension feeding bivalves. Ophelia, 17, 239-246.

Murillo, F.J., Muñoz, P.D., Cristobo, J., Ríos, P., González, C., Kenchington, E., Serrano, A. (2012). Deep-sea sponge grounds of the Flemish Cap, Flemish Pass and the Grand Banks of Newfoundland (Northwest Atlantic Ocean): distribution and species composition. Marine Biology Research, 8, 842-854.

Murray, H.J.R. (2009). Oxygen consumption rates of sponges and the effect of UV-B radiation and sediment. Victoria University of Wellington, New Zealand, MSc thesis.

Oebius, H.U., Becker, H.J., Rolinski, S, Jankowski, J.A. (2001). Parametrization and evaluation of marine environmental impacts produced by deep-sea manganese nodule mining. Deep-Sea Research Part II, 48, 3453-3467. 
Orpin, A., Ridd, P. (2012). Exposure of inshore corals to suspended sediments due to waveresuspension and river plumes in the central Great Barrier Reef: A reappraisal. Continental Shelf Research, 47, 55-67.

Paradis, S., Masque, P., Puig, P., Juan-Diaz, X., Gorelli, G., Company, J.B., Palanques A. (2018). Enhancement of sedimentation rates in the Foix Canyon after the renewal of trawling fleets in the early XXIst century. Deep-Sea Research Part I, 132, 51-59.

Perea-Blázquez, A. (2011). Interactions between sponges and the water column: nutrient utilisation and feeding by New Zealand subtidal sponges. A Thesis submitted to the Victoria University of Wellington, $162 \mathrm{pp}$.

Perea-Blázquez, A., Davy, S.K., Bell, J.J. (2012). Estimates of particulate organic carbon flowing from the pelagic environment to the benthos through sponge assemblages. PLoS ONE, 7, e29569. doi:10.1371/journal.pone.0029569.

Perea-Blázquez, A., Davy, S.K., Magana-Rodríguez, B., Bell, J.J. (2013). Temporal variation in food utilisation by three species of temperate demosponge. Marine Ecology Progress Series, 485, 91-103.

Pineda, M.C., Strehlow, B., Sternel, M., Duckworth, A., Jones, R., Webster, N. S. (2017). Effects of suspended sediments on the sponge holobiont with implications for dredging management. Scientific Reports, 7, 4925.

R Core Team (2020). R: A language and environment for statistical computing. R Foundation for Statistical Computing, Vienna, Austria. URL https://www.R-project.org/.

Reisinger, A., Kitching, R.L., Chiew, F., Hughes, L., et al. (2014). Australasia. In: Barros, V. R., Field, C.B ., Dokken, D.J., Mastrandrea, M.D., Mach, K.J., Bilir, T.E., Chatterjee, M., Ebi, K.L., Estrada, Y.O., Genova, R.C., Girma, B., Kissel, E.S., Levy, A.N., MacCracken S., Mastrandrea, P.R., White, L.L. (Editors). Climate Change 2014: Impacts, Adaptation, and Vulnerability. Part B: Regional Aspects. Contribution of Working Group II to the Fifth Assessment Report of the Intergovernmental Panel on Climate Change. Cambridge, United Kingdom and New York, NY, USA: Cambridge University Press; pp. 1371-1438.

Reiswig, H. (1971). In situ pumping activities of tropical Demospongiae. Marine Biology, 9, $38-50$. 
Riisgård, H.U. (1988). Efficiency of particle retention and filtration rate in 6 species of Northeast American bivalves. Marine Ecology Progress Series, 45, 217-223.

Roberts, J.M., Wheeler, A.J., Freiwald, A. (2006). Reefs of the deep: the biology and geology of cold-water coral ecosystems. Science, 312, 543-547.

Rolinski, S., Segschneider, J. Sundermann, J. (2001). Long-term propagation of tailings from deep-sea mining under variable conditions by means of numerical simulations. Deep-Sea Research II, 48, 3469-3485

Rützler K. (1997). The role of psammobiontic sponges in the reef community. In: Lessios H. A. and Macintyre I. G. (eds) Proceedings of the Eighth International Coral Reef Symposium, Panama City, 24 - 29 June 1996, Volume 2. Balboa: Smithsonian Tropical Research Institute, pp. 1393-1398.

Scanes, E., Kutti, T., Fang, J.K.H., Johnston, E.L., Ross, P.M, Bannister, R.J. (2018). Mine waste and acute warming induce energetic stress in the deep-sea sponge Geodia atlantica and coral Primnoa resedeaformis; results from a mesocosm study. Frontiers in Marine Science, 5:129. doi: 10.3389/fmars.2018.00129.

Schönberg, C.H.L. (2016). Happy relationships between marine sponges and sediments - a review and some observations from Australia. Journal of the Marine Biological Association of the United Kingdom, 96, 493-514.

Schwarz, A.M., Taylor, R., Hewitt, J., Philips, N., Shima, J., Cole, R., Budd, R. (2006). Impacts of terrestrial runoff on the biodiversity of rocky reefs. New Zealand Aquatic Environment and Biodiversity Report. No. 7, 109 p. ISSN 1176-9440.

Shears, N.T. (2007). Biogeography, community structure and biological habitat types of subtidal reefs on the South Island West Coast, New Zealand. Science \& Technical Publishing, Department of Conservation, New Zealand. 53 p.

Siciliano, A., D.R. Schiel, M.S. Thomsen. (2019). Effects of local anthropogenic stressors on a habitat cascade in an estuarine seagrass system. Marine and Freshwater Research, 70, 11291142 .

Storlazzi, C.D., Field, M.E., Bothner, M.H., Presto, M.K., Draut, A.E. (2009). Sedimentation processes in a coral reef embayment: Hanalei Bay, Kauai. Marine Geology, 264, 140-151. 
Strehlow, B.W., Jorgensen, D., Webster, N.S., Pineda, M.C., Duckworth, A. (2016). Using a thermistor flowmeter with attached video camera for monitoring sponge excurrent speed and oscular behaviour. PeerJ, 4, 2761.

Strehlow, B.W., Pineda, M., Duckworth, A., Kendrick, G.A., Renton, M., Abdul Wahab, M. A., Webster, N.S., Clode, P.L. (2017). Sediment tolerance mechanisms identified in sponges using advanced imaging techniques. PeerJ, 5, e3904 https://doi.org/10.7717/peerj.3904

Stubler, A.D., Duckworth, A.R., Peterson, B.J. (2015). The effects of coastal development on sponge abundance, diversity, and community composition on Jamaican coral reefs. Marine Pollution Bulletin, 96, 261-270.

Syvitski, J.P.M., Vörösmarty, C.J., Kettner, A.J., Green, P. (2005). Impact of humans on the flux of terrestrial sediment to the global coastal ocean. Science, 308, 376-380.

Te Velde, K. (2018). The effect of CO2 concentrations on blue mussel (Mytilus edulis) behaviour, health, mortality and detachment rates: a new potential way of anti-fouling. MSc Thesis.

Thrush, S.F., Dayton, P.K. (2002). Disturbance to marine benthic habitats by trawling and dredging: implications for marine biodiversity. Annual Review of Ecology and Systematics, $33,449-473$.

Thrush, S.F., Hewitt, J.E., Cummings, V.J., Ellis, J.I., Hatton, C., Lohrer, A., Norkko, A. (2004). Muddy waters: elevating sediment input to coastal and estuarine habitats. Frontiers in Ecology and the Environment, 2, 299-306.

Tjensvoll, I., Kutti, T., Fosså, J.H., Bannister, R.J. (2013). Rapid respiratory responses of the deep-water sponge Geodia barretti exposed to suspended sediments. Aquatic Biology, 19, 6573.

Tompkins-MacDonald G.J., Leys S.P. (2008). Glass sponges arrest pumping in response to sediment: implications for physiology of the hexactinellid conduction system. Marine Biology, 154, 973-984.

Vahl, O. (1972). Efficiency of particle retention in Mytilus edulis L. Ophelia, 10, 17-25.

Walker, J.W. (2007). Effects of fine sediments on settlement and survival of the sea urchin Evechinus chloroticus in northeastern New Zealand. Marine Ecology Progress Series, 331, $109-118$. 
Wilkinson, C.R., Evans, E. (1989). Sponge distribution across Davies Reef, Great Barrier Reef, relative to location, depth, and water movement. Coral Reefs, 8, 1-7.

Wolanski. E., Fabricius. K., Spagnol. S., Brinkman. R. (2005). Fine sediment budget on an inner-shelf coral-fringed island, Great Barrier Reef of Australia. Estuarine, Coastal and Shelf Science, 65, 153-158. 


\section{Chapter 3. Short-term physiological responses of the New Zealand deep-sea sponge Ecionemia novaezealandiae to elevated}

\section{concentrations of suspended sediments}

\section{Abstract}

The generation of sediment plumes by human activities, such as bottom fishing and potential deep-sea mining, pose threats to deep-sea benthic fauna. Sponges are important components of deep-sea ecosystems and can be particularly sensitive to elevated suspended sediment concentrations. In this study, I exposed the deep-sea New Zealand sponge Ecionemia novaezealandiae (Dendy, 1924) (Class: Demospongiae; Family Ancorinidae) to four target sediment concentrations $\left(0,50,100\right.$ and $\left.500 \mathrm{mg}^{-1}\right)$ continuously for two weeks. Survival was high (97\%), with only one death (at the highest SSC). Half of the sponges in the $500 \mathrm{mg} \mathrm{l}^{-1}$ treatment showed partial necrosis by the end of the two-week exposure. Respiration rates of sponges in the sediment addition treatments decreased relative to control sponges by 27,37 and $60 \%$, respectively, after day 1 ; and by 7,17 , and $27 \%$, respectively, after 14 days of suspended sediment exposure. At the end of the experiment, sectioning of the sponges revealed the sediments deep in the tissue of all specimens, including controls, indicating previous incorporation of sediment occurred in their natural environment. Despite the high survival, the decreased respiration rates and partial necrosis with increasing SSC indicated decline in sponge condition that could affect this species beyond the disturbance period.

\subsection{Introduction}

The deep-sea (here defined as below 200 metres) covers around $90 \%$ of the marine environment and is increasingly experiencing anthropogenic stressors as result of the exploitation of the biological and mineral resources it contains (Ramirz-Llodra et al., 2010; Mengerik et al., 2014). Offshore bottom fishing activities and industries focused on deep-sea regions, such as oil drilling, cable laying, and mineral exploration, have been increasing in recent decades (Glover and Smith, 2003; Ramirez-Llodra et al., 2015). Bottom-contact activities pose several threats to deep-sea ecosystems as they generally lead to removal of the substrate and associated fauna, and to modification of seabed morphology. Such anthropogenic disturbance can impact benthic communities and lead to habitat modification or, in some cases, 
complete habitat loss (e.g., see Clark et al. 2016; Levin et al., 2016). Some of these activities, particularly bottom fishing and proposed deep-sea mining, also have the potential to generate sediment plumes and deposits, which can lead to burial and smothering of fauna (Hall-Spencer et al., 2002; Boschen et al., 2016).

Bottom contact fishing gear and several types of potential deep-sea mining operations can create a disturbance that extends up to 10 centimetres into the seafloor and can re-suspend bottom sediments into the water column. Suspended sediments may reach concentrations up to $500 \mathrm{mg} \mathrm{l}^{-1}$, and can form plumes that could extend over hundreds of kilometres depending on local hydrodynamic conditions (Schoellhamer 1996; Durrieu de Madron et al., 2005; Bradshaw et al., 2012; Parsons et al., 2013). While larger sediment particles tend to settle quickly, fine particles can remain in suspension for days to weeks and be transported over hundreds of kilometres by currents (Rolinski et al. 2001, Lepland and Mortensen, 2008). Bottom contact fishing practises and deep-sea mining operations may, therefore, contribute substantially to sediment resuspension and transport in areas where natural sediment suspension is generally low (Ferré et al. 2008), potentially leading to severe and long-lasting effects on the associated benthic communities (Miller et al., 2002; Gollner et al. 2017), including sponges (e.g., Xavier et al. 2015, Pham et al. 2019).

Elevated suspended sediment concentrations in the water column can be particularly harmful to benthic suspension and filter feeders as they may clog their filtration system, altering respiration, feeding ability and, indirectly, growth and reproduction (Ellis et al., 2002; Hewitt $\&$ Norkko, 2007). Sponges are primarily suspension feeders that can dominate and provide key ecosystem services in some deep-sea benthic environments (e.g., lower shelf, bathyal and/or abyssal depths) (Murillo et al., 2002; Klitgaard \& Tendal 2004; Longo et al., 2005; Bell, 2008; Maldonado et al., 2017; Cathalot et al., 2015). In some areas deep-sea sponges comprise up to $90 \%$ of the benthic biomass (Murillo et al., 2012; Klitgaard \& Tendal 2004). These high biomasses are responsible for significant nitrogen, carbon and silica cycling processes (Pile and Young, 2006; Chu et al., 2011; Kahn et al., 2015). Furthermore, deep-sea sponge gardens can, along with corals, provide structurally complex habitats that support high abundance and diversity of fish and invertebrates (Tracey et al., 2011; Clark \& Dunn, 2012; Hourigan et al 2017). Because of their vulnerability and importance for deep-sea ecosystems, these sponge habitats have been classified as Vulnerable Marine Ecosystems (VMEs) by the United Nations (FAO, 2009). 
Although it has been estimated that $10 \%$ of all sponges are well adapted to life in areas with high levels of suspended and settled sediment (Schönberg, 2016), there is also evidence that sediment can be deleterious to many sponge species at the individual and population levels (Bell et al., 2015). Sponges exposed to elevated concentrations of suspended sediment may fine particles into their aquiferous system and choanocyte chambers (Tompkins-MacDonald and Leys, 2008), which can result in clogging of their filtration apparatus. Suspended sediments can also induce a reduction in sponge pumping activity (Lohrer et al., 2006; TompkinsMacDonald \& Leys, 2008, Strehlow et al., 2016; Grant at al., 2018; 2019), which can affect feeding efficiency (Lohrer et al., 2006), alter respiration rates (Bannister et al., 2012; Tjensvoll et al., 2013; Kutti et al., 2015; Pineda et al., 2017), cause tissue abrasion (Nava \& Carballo, 2013), and possibly result in reduced survival (Maldonado et al., 2008). Most sponges have been shown to decrease their respiration rates when exposed to SSCs (Lohrer et al., 2006; Tjensvoll et al., 2013; Kutti et al., 2015; Pineda et al., 2017), however, some sponges increased their oxygen consumption (Bannister et al., 2012; McGrath et al., 2017) and others were not affected (C. incrustans, Chapter 2). The effects may depend on both the sediment concentration and sediment properties (i.e. grain size and type; see Bannister et al., 2012; Kutti et al., 2015).

To date most sedimentation impact studies have been on shallow-water species (e.g. Biggerstaff et al., 2017, McGrath et al., 2017, Pineda et al., 2017, Chapter 2), with only three deep-sea studies I am aware of globally, all of which are on sponges belonging to the genus Geodia (Tjensvoll et al., 2013; Kutti et al., 2015; Scanes et al., 2018). However, sponges are common in the deep seas around New Zealand (Bowden et al., 2017), areas that are subject to bottom trawl and longline fisheries (Fisheries New Zealand, 2020) and are of interest for seabed minerals (Ellis et al., 2017). In 2015, a marine consent application to mine phosphorite nodules on the Chatham Rise (north eastern New Zealand) was declined due to uncertainty about the nature and the extent of adverse effects on biological communities (including effects of suspended and settled sediment) (NZ EPA, 2015). Models investigating mining plume dispersion on the Chatham Rise predicted peak suspended sediment concentrations of $100 \mathrm{mg}$

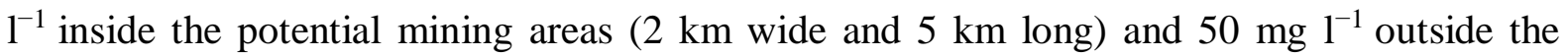
potential mining areas (Deltares, 2014). In addition to the Chatham Rise being an important area for New Zealand fisheries (with almost $50 \%$ of the total EEZ area trawled in waters shallower than $1000 \mathrm{~m}$; Black et al., 2013), there is a strong impetus to assess potential impacts of sediment on deep-sea species to help inform management of human activities. 
The aim of this chapter was to assess the physiological response of the brain-shaped sponge Ecionemia novaezealandiae (Dendy, 1924), a species common on the Chatham Rise (Kelly \& Sim-Smith, 2012), to short term (one day and two weeks) exposure to suspended sediments. I investigated responses to suspended sediment concentrations relebant to potential deep-sea mining operations and bottom fishing activities on the Chatham Rise. This is the first such investigation of a deep-sea New Zealand sponge to these impacts.

\subsection{Materials and methods}

\subsubsection{Sponge collection and maintenance}

In June 2019, twenty E. novaezealandiae samples were collected by beam trawl from about $300 \mathrm{~m}$ on the Chatham Rise during a National Institute of Water and Atmospheric Research (NIWA) voyage of RV Tangaroa (Clark et al., 2019). Temperature was recorded in situ with a conductivity, temperature and depth $(\mathrm{CTD})$ profiler $\left(\sim 10^{\circ} \mathrm{C}\right)$. Sponges taken from the trawl codend were placed immediately into cooled seawater $\left(10^{\circ} \mathrm{C}\right)$ and gently shaken underwater to remove any potential air bubble that could block the aquiferous system (Osinga et al., 1999). According to Fosså \& Nielsen (1996), many sponges die after even a short exposure to air, if the air in their canals was not removed. E. novaezealandiae showed no visible signs of distress (mortality or necrosis) in the several weeks following collection, and they were respiring (as indicated by a drop in oxygen levels during measurements), indicating that the brief exposure to air during collection had not affected their health status. Sponges were then transferred to a flow-through on-board aquaria system with fresh $10^{\circ} \mathrm{C}$ seawater (filtered to $1 \mathrm{~mm}$ ) and held in the dark. At the end of the voyage, circa $24 \mathrm{~h}$ after collection, sponges were transferred to the Marine Environmental Manipulation Facility at NIWA, Wellington. Here the sponges were kept in the dark, in flow-through holding tanks with fresh seawater (filtered to $0.1 \mu \mathrm{m}$, so that all the food was removed), and at temperatures similar to those at the collection site (9.5 to $10^{\circ} \mathrm{C}$ ). Any epibionts were removed from the sponge surfaces so to not affect their responses to the experimental treatments (i.e. respiration rates). Out of the 20 sponges collected, the 13 largest ones $(\sim 20 \times 20 \mathrm{~cm})$ were cut into smaller 'clones' $(\sim 5 \times 6 \mathrm{~cm})$ to ensure comparability across treatments and to provide replicates, and each clone had more than one osculum. Smaller sponges $(N=7)$ were not cut into clones. Sponges were then left undisturbed for four weeks to stabilise and heal tissue damage from cutting before the experiment began. Recovery from 
cutting was assessed as observing pinacoderm growth over the surface of the cut. This metric of post-cutting recovery assessment has also been used by Bennett et al. (2017), who also allowed four weeks of acclimation post-cloning. Sponges were fed every other day with Nannochloropsis microalgae (1-2 $\mu \mathrm{m}$ cell diameter; Nanno $3600^{\mathrm{TM}}$ Reed Mariculture, U.S.). Nanno $3600^{\mathrm{TM}}$ commercial food was chosen for its cell size compatibility with sponge diet, after ensuring, based on literature evidence, that deep-sea sponges feed on phytoplankton, both in situ and when sampled and maintained under laboratory conditions (e.g. see Yahel et al., 2006; Robertson et al., 2017). Immediately prior to the start of the experiment, all sponges were photographed, weighed (buoyant weight), and randomly distributed amongst 16 experimental chambers (two per chamber; described below), ensuring that clones originating from the same donor sponge were placed across different chambers and treatments (i.e. clones were tracked).

\subsubsection{Sediment treatments}

Sponges were exposed to four different target concentrations of suspended sediment (SSCs): $0,50,100,500 \mathrm{mg} \mathrm{l}^{-1}$, with $\mathrm{N}=4$ replicate experimental chambers for each treatment. The SSCs were chosen to include those predicted from models investigating mine plume dispersion on the Chatham Rise (50-100 $\mathrm{mg} \mathrm{l}^{-1}$; Deltares, 2014) and empirically-derived concentrations of sediments re-suspended by bottom trawling (up to $500 \mathrm{mg}^{-1}$ ). Sponges were exposed to the target SSCs for a two-week period, mimicking bottom-contact fishing activities and potential deep-sea mining operating for short periods in this area.

\subsubsection{Sediment collection and manipulation}

Natural sediment samples $(3-150 \mu \mathrm{m})$ were collected with a multicorer from the Chatham Rise. The top $5 \mathrm{~cm}$ of the sediment column were used for this experiment, as this surface layer is most likely to be disturbed and resuspended in the water column by bottom-contact fisheries and mining (Palanques et al., 2001). Sediments were frozen at $-20^{\circ} \mathrm{C}$ to kill any living fauna. Prior to use in the experiment, sediments were thawed and dried at $100^{\circ} \mathrm{C}$ overnight, and then sieved (150 $\mu \mathrm{m}$ mesh). Sediment samples were analysed with a Beckam Coulter LS 13-120 Dual Wavelength Laser Particle Sizer to determine particle size distribution. Sediments had a 
mean diameter of $50 \mu \mathrm{m}$, and were comprised of $\sim 68 \%$ of mud and $\sim 32 \%$ very fine sand (Figure A2.1) (GRADISTAT version 8.0; Blott, 2010).

Target suspended sediment concentrations were obtained by manually adding a sediment slurry (dried sediment mixed with seawater) to each experimental chambers. SSCs in the chambers were monitored twice daily using a hand-held turbidity meter (Seapoint Turbidity meter) connected to a multimeter that displayed $\mathrm{mV}$. The relationship between suspended sediment concentrations (SSCs) and optical turbidity $(\mathrm{mV})$ had been determined prior to the experiment for a large range of concentrations (Appendix two, Figure A2.2). When the $\mathrm{mV}$ reading from the turbidity meter was lower than the target $\mathrm{mV}$ more sediment was added manually to the chamber. The amount of sediment added was determined by the difference between the target SSC and the voltage reading, using the calibration curve (Appendix 2, Figure A2.2). Suspended sediment concentrations in each chambers were also determined gravimetrically. Each week, three aliquots of $50 \mathrm{ml}$ were sampled from each chamber and filtered through pre-dried $\left(60{ }^{\circ} \mathrm{C}\right)$ and pre-weighed $25 \mathrm{~mm} \mathrm{GF} / \mathrm{F}$ (Whatman) filters and dried to constant weight at $60{ }^{\circ} \mathrm{C}$.

\subsubsection{Experimental chambers}

The experimental chambers (38 1 in volume) were a modification of the chambers used in Chapter 2. The system consisted of a cylindrical tank, tapered at the base that allowed sediment falling out of suspension to accumulate in a small sump area (Figure 3.1). At the centre of each chamber was a PVC pipe ( $80 \mathrm{~mm}$ diameter) with openings at the bottom to allow the sediment in. A motorised polycarbonate auger (200 mm length, triple spiral helix design) located at the bottom of the pipe agitated the settled sediment and facilitated its resuspension by creating an upward flow inside the pipe. The flow created was forced out through three holes $(27 \mathrm{~mm})$ located just below the water surface, allowing the sediment to be reintroduced to the chambers. This also created a vortex flow inside the chamber, allowing regular water mixing and retaining sediments in suspension. At the base of each chamber was a plastic grid $\left(1 \mathrm{~cm}^{2}\right)$ on which the sponges sat in individual open top coarse mesh baskets, allowing the sediment to fall through and under them (Figure 3.1). 


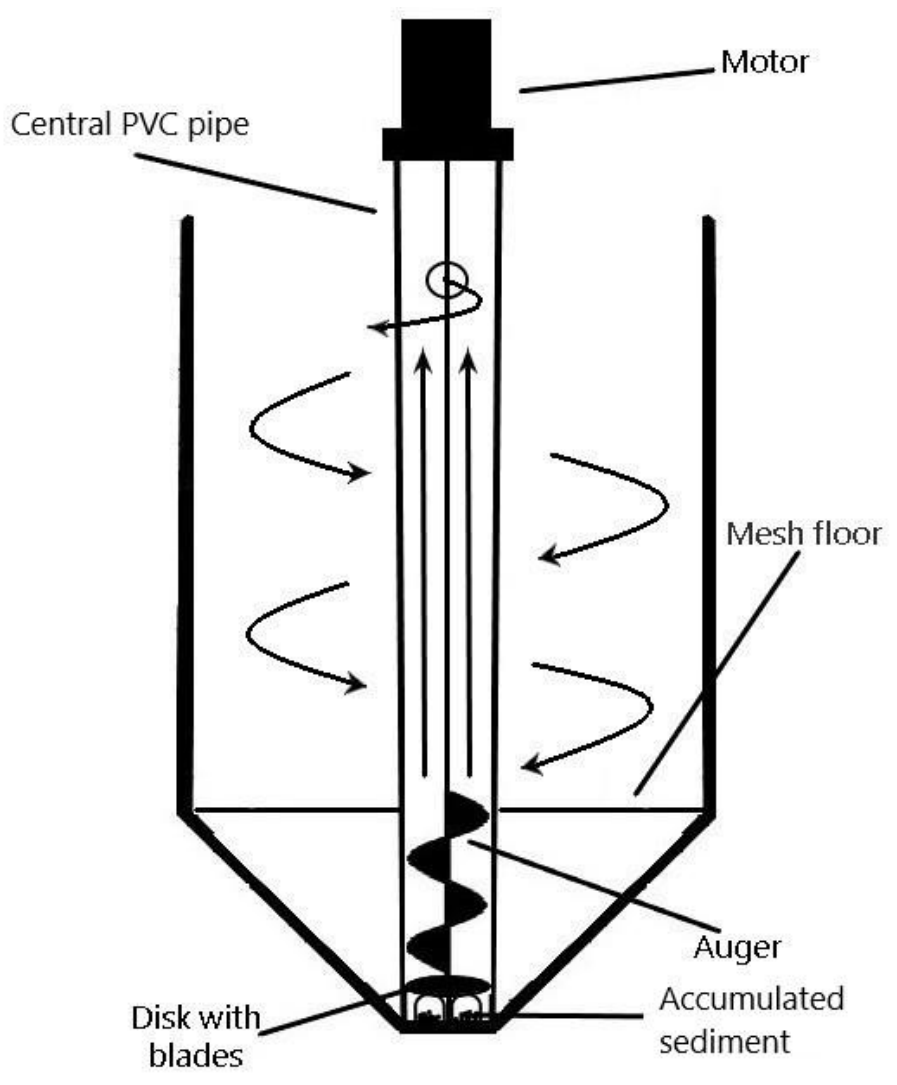

Figure 3.1. Schematic of an experimental chamber used in this study. Direction of water flow is shown by the arrows. The auger, driven by the motor, creates an upward water flow into the central PVC pipe. This flow resuspends and pushes the sediment accumulating at the bottom of the chamber up the pipe and back into the chamber through the holes near the top of the pipe.

Chambers were supplied with seawater at a rate of approximately $1.51 \mathrm{~h}^{-1}$. An outflow pipe with a filter (polyester fibre) prevented the sediment being lost through the outflow water. This filter was cleared daily and any sediment retained was reintroduced to the chamber.

\subsubsection{Sponge response measures}

Sponges were left for $48 \mathrm{~h}$ to acclimate in the experimental chambers before sediment was added (experiment start, $\mathrm{T}_{0}$ ).

Respiration rate measurements, photographs and buoyant weights were taken after one day of sediment exposure $\left(T_{1}\right)$ on one sponge per chamber, and the sponges were returned to the 
chambers. At the end of the experiment, after two weeks of sediment exposure $\left(\mathrm{T}_{14}\right)$, these measurements were made on the two sponges in each chamber (total $\mathrm{N}=32$; Figure 3.2). Also at the end of the experiment, all sponges were sectioned, and photographs of the sections were taken to assess internal degradation (necrosis) and sediment accumulation.
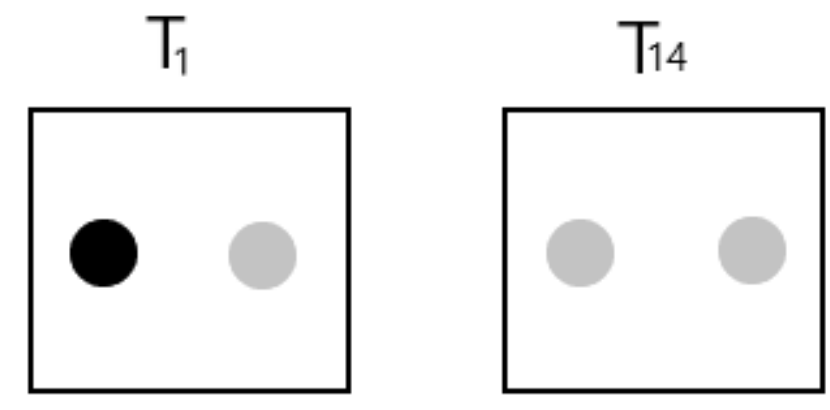

Figure 3.2. Schematic representation of the experiment sampling design. Squares represent sediment chambers, dots represent sponge samples. Grey dots represent sponges sampled at $\mathrm{T}_{1}$ and $\mathrm{T}_{14}$.

\subsubsection{Respiration rates}

Respiration rates were measured at $T_{1}$ and $T_{14}$ in sealed 2.31 respiration chambers fitted with individual oxygen probes (D-Opto SDI Optical dissolved oxygen sensor). Mixing of the chamber water was achieved using a magnetic stir bar located in a separate compartment at the bottom of each chamber. The respiration chambers were immersed in a flow-through water bath to maintain constant water temperature $\left(\sim 10^{\circ} \mathrm{C}\right)$.

Sponges were added to the respiration chambers (one per chamber) and acclimated for 20 minutes before the chambers were sealed and dissolved oxygen (DO) readings started. Continuous measurements were taken for 30 minutes. I could not detect if sponges were pumping with fluorescein dye, however I considered that the decline of DO over time was indicative that the sponges were pumping. I made sure that oxygen concentration inside the respiration chambers did not drop below $70 \%$ saturation. Blank incubations containing only seawater were used to correct for any microbial community respiration in the seawater. Respiration rates $\left(\mathrm{mg} \mathrm{O}_{2} \mathrm{~h}^{-1} \mathrm{l}^{-1} \mathrm{~g}^{-1}\right.$ ash free dry weight (AFDW)) were determined after 
adjusting for the volume of water in the chamber and the sponge AFDW. AFDW was determined on sponges at $\mathrm{T}_{14}$ by oven drying the sponge $\left(60^{\circ} \mathrm{C}\right)$ to constant weight, and ashing $\left(500{ }^{\circ} \mathrm{C}\right.$ for $5 \mathrm{~h}$ ). The relationship between sponge buoyant weight and AFDW at $\mathrm{T}_{14}$ was determined by performing a linear regression in order to obtain sponge AFDW at $\mathrm{T}_{1}\left(\mathrm{R}^{2}=0.94\right.$; Appendix two, Figure A2.3).

\subsubsection{Necrosis and sediment accumulation}

Photographs of the sponges were taken using a Nikon D850 camera (50 mm lens). In order to detect any sediment accumulation on the upper sponge surface, and necrosis over the experiment, photographs taken at $\mathrm{T}_{0}, \mathrm{~T}_{1}$ and $\mathrm{T}_{14}$ were compared using ImageJ (Schneider et al., 2012). To detect the presence of any internal necrosed tissue (identified as a darkening of the sponge tissue compared to healthy tissue; Figure 3.2), sponges were sectioned and photographed at $\mathrm{T}_{14}$. A scale and grey colour bar were included in the photographs to aid the comparisons. Sediment accumulation was calculated as the percentage of the sponge surface covered by sediment.

\subsubsection{Statistical analysis}

I investigated the effects of SSC treatment $\left(0,50,100,500 \mathrm{mg} \mathrm{l}^{-1}\right)$ and time $\left(\mathrm{T}_{1}, \mathrm{~T}_{14}\right)$ on sponge responses (respiration rates and sediment accumulation on the sponge surface) using a linear mixed effects analysis in R. I used the lmer() function in the lme4 package to carry out the mixed model (Bates et al., 2015) and the anova() function in the lmerTest package to provide P-values and approximate degrees of freedom of the model (Kuznetsova et al., 2017). Equal variance and normal distribution assumptions were evaluated via analysis of the residuals. Variance and normality assumptions were tested with Levene's and Shapiro-Wilk test, respectively. Respiration rates were $\log (x+1)$ transformed to meet normality assumptions. Fixed effects were treatment and time, with interaction terms; random effects were sponge (to account for repeated measures), entered with two levels of random effects (one associated with dponge 'donors', one associated with sponge 'clone'; sponge 'clones' nested within sponge 'donors'), and chambers (C01-C16). Chamber effect was included to address pseudoreplication, as two sponges were located in each chamber. Dead sponges $(\mathrm{N}=1)$ and sponges 
with any level of partial necrosis $(\mathrm{N}=6)$ were excluded from the respiration rates analysis, as they were considered compromised. Tukey post hoc pairwise comparisons were conducted for significant results to determine where significant differences between treatment groups existed. A one-way ANOVA was performed to test if the inorganic content of the three treatment sponge groups was higher than the control as a result of more sediment incorporation. Statistical analyses and plots were performed in R version 3.6.3 (R Core Team, 2020).

\subsection{Results}

\subsubsection{Sediment treatments}

Gravimetric analysis showed that the SSCs in the chambers were on average $\sim 20 \mathrm{mg}^{-1}$ lower than the target concentrations (Appendix two, Figure A2.4), i.e. $31.96 \pm 1.75 \mathrm{mg} \mathrm{l}^{-1}, 77.92 \pm$ $3.16 \mathrm{mg} \mathrm{l}^{-1}, 474.95 \pm 5.38 \mathrm{mg}^{-1}$ (mean $\pm \mathrm{SE}$ ), cf. 50, 100 and $500 \mathrm{mg} \mathrm{l}^{-1}$. For simplicity, I refer to target SSCs from here on.

\subsubsection{Respiration rates}

SSC had a significant effect on sponge respiration rates $\left(\mathrm{F}_{(3,23)}=3.85, \mathrm{p}=0.0224\right.$; Table 1), which were significantly lower in sponges from the $500 \mathrm{mg}^{-1}$ treatment than in the control at $\mathrm{T}_{1}$ (Figure 3.3; Appendix two, Table A2.2). Mean respiration rates of the 50, 100 and $500 \mathrm{mg}$ $1^{-1}$ treatment sponges at $\mathrm{T}_{1}$ dropped by 27,37 and $60 \%$, respectively, compared to the control sponges. At $\mathrm{T}_{14}$, treatment sponge respiration rates were lower by 7,17 and $27 \%$ in the 50 , 100 and $500 \mathrm{mg} \mathrm{l}^{-1}$ SSCs, respectively, compared to the control. Mean respiration rates of sponges in the $500 \mathrm{mg}^{-1}$ treatment were similar at $\mathrm{T}_{1}$ and $\mathrm{T}_{14}(0.086 \pm 0.0323$ vs $0.0962 \pm$ $0.0104 \mathrm{mg} \mathrm{O}_{2} \mathrm{~h}^{-1} \mathrm{l}^{-1} \mathrm{~g}(\mathrm{AFDW})^{-1}$; mean $\left.\pm \mathrm{SE}\right)$. Respiration rates decreased at higher SSC, and this effect was stronger at $T_{1}$ (Figure 3.3). At $T_{1}$, sponge respiration rates were also more variable than at $\mathrm{T}_{14}$. However, there was no significant effect of time $\left(\mathrm{F}_{(1,22)}=4.11, \mathrm{p}=0.0541\right.$; Table 1), and no time*treatment interaction ( $\mathrm{p}>0.05$; Table 3.1). 


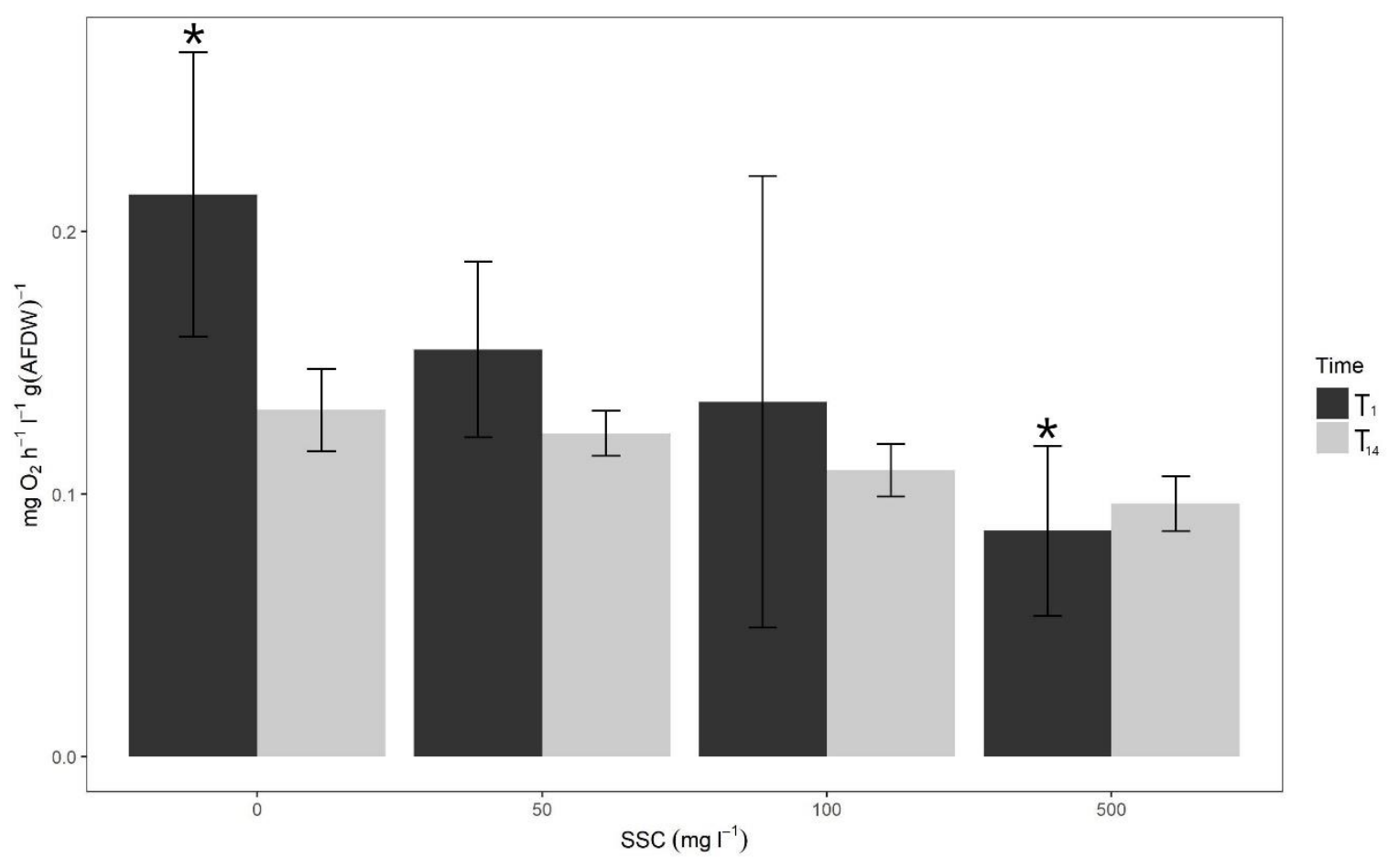

Figure 3.3. Respiration rates of Ecionemia novaezealandiae in each of the experimental treatments after one $\left(\mathrm{T}_{1}\right)$ and $14\left(\mathrm{~T}_{14}\right)$ days of exposure. Bars show mean values $(\mathrm{SE}) . \mathrm{N}=4$. Asterisks indicate where significance differences occur.

Table 3.1. ANOVA table and summary of General Linear Mixed Model assessing the effects of SSC and time on: (A) respiration rates; and (B) sediment coverage of Ecionemia novaezealandiae $. \mathrm{DF}=$ degrees of freedom, $\mathrm{DFD}=$ degrees of freedom denominator, $\mathrm{SS}=$ sum of squares, MS = mean squares. Significant values are shown in bold.

\begin{tabular}{lllllll}
\hline & DF & DFD & \multicolumn{1}{l}{ SS } & MS & F-value & Pr $>F$ \\
\hline A) Respiration rates & & & & & & \\
\hline Treatment & 3 & 23.47 & 0.0035 & 0.0011 & 3.85 & $\mathbf{0 . 0 2 2 4}$ \\
Time & 1 & 22.98 & 0.0012 & 0.0012 & 4.11 & 0.0541 \\
Treatment*Time & 3 & 22.78 & 0.0012 & 0.0004 & 1.33 & 0.2871 \\
\hline B) Sediment coverage & & & & & & \\
\hline Treatment & 3 & 26.02 & 16371.6 & 5457.2 & 13.18 & $<\mathbf{0 . 0 0 1}$ \\
Time & 1 & 16.41 & 4280.8 & 4280.8 & 10.34 & $\mathbf{0 . 0 0 5 2}$ \\
Treatment*Time & 3 & 16.41 & 1458.2 & 486.1 & 1.17 & 0.3496 \\
\hline
\end{tabular}




\subsubsection{Sponge survival and health}

Sponge survival was high with only one death noted in the $500 \mathrm{mg}^{-1}$ treatment at $\mathrm{T}_{14}$. Sectioning of the sponges showed partial internal necrosis (Figure 3.4) in six sponges across treatments: one control sponge, two sponges in the $100 \mathrm{mg}^{-1}$ treatment and three sponges in the $500 \mathrm{mg}^{-1}$ treatment. The dead sponge and one with partial necrosis in the $500 \mathrm{mg} \mathrm{l}^{-1}$ treatment were from the same experimental chambers; all other sponges with partial necrosis were in different chambers. All other sponges appeared visibly healthy at $\mathrm{T}_{14}$.

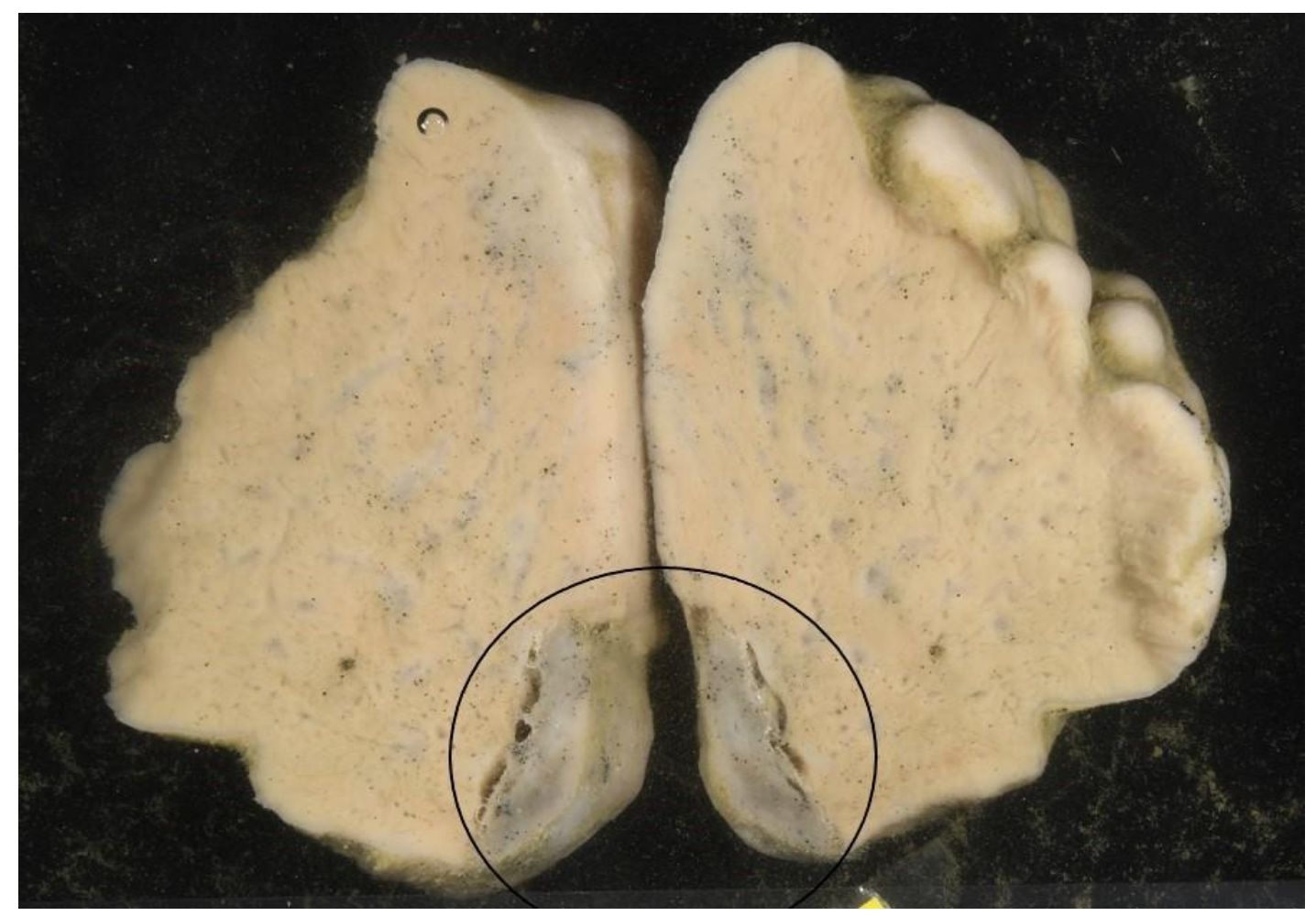

Figure 3.4. Section of treatment sponge showing a portion of necrosed tissue (circled in black). This sponge was in the $500 \mathrm{mg}^{-1} \mathrm{SSC}$ treatment.

\subsubsection{Sediment coverage}

The settling out of suspended sediment resulted in partial sediment accumulation on the sponge surfaces (Figure 3.5). Careful removal of sediment from the sponge surface after photography at $\mathrm{T}_{14}$ did not reveal any physical damage to the sponge surface (i.e. scouring/abrasion). 


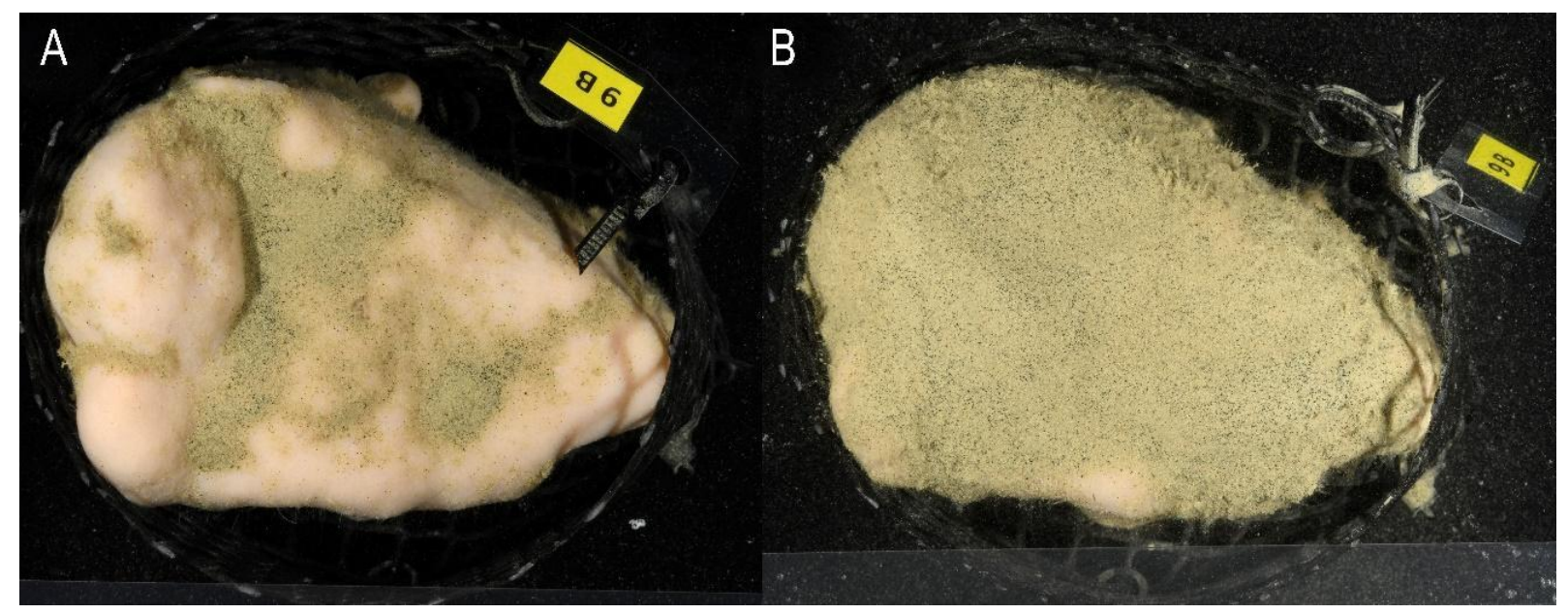

Figure 3.5. Sediment layer covering Ecionemia novaezealandiae after: A) one day of sediment exposure; and B) 14 days of sediment exposure. This sponge was in the $100 \mathrm{mg}^{-1} \mathrm{SSC}$ treatment.

There was a positive correlation between the percentage of sponge surface covered by sediment and SSC level (Figure 3.6), which was statistically significant $\left(\mathrm{F}_{(3,26)}=13,18, \mathrm{p}<0.001\right.$; Table 3.1). However, Tukey post hoc pairwise comparisons showed that only the control treatment was significantly different from each of the three elevated SSC treatments, and there were no significant differences between SSC levels (Figure 3.6; Appendix two, Table A2.3). The percentage of sponge surface covered by sediment was significantly greater at $\mathrm{T}_{14}$ in treatment sponges compared to $\mathrm{T}_{1}\left(\mathrm{~F}_{(1,16)}=10.34, \mathrm{p}=0.00525\right.$; Table 3.1). GLMM random effects coefficients are reported in the appendix (Appendix two, Table A2.1). 


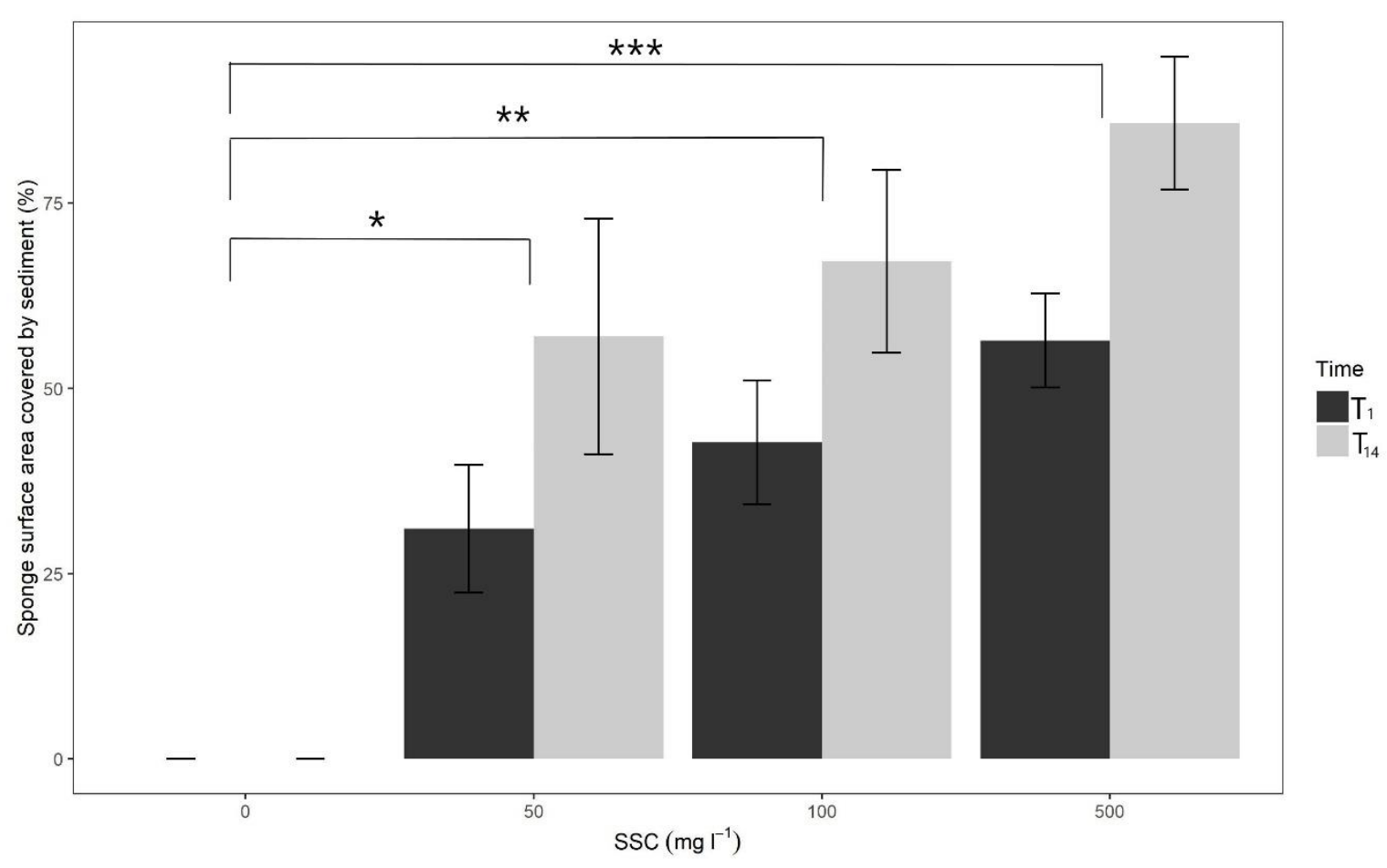

Figure 3.6. Percentage of the surface of Ecionemia novaezealandiae covered by sediment in each of the experimental treatments after one $\left(T_{1}\right)$ and $14\left(T_{14}\right)$ days of exposure. Bars show mean values ( $\mathrm{SE}$ ). $\mathrm{N}=4$. Asterisks indicate where significant differences occur.

\subsubsection{Sediment incorporation}

Sponge sections revealed the presence of internal sediment in almost all sponges, including control sponges. Qualitative visual assessments showed that the presence and the amount of sediment incorporation was independent of the SSC treatments, with some control sponges having more sediment than treatment sponges (Figure 3.7). 


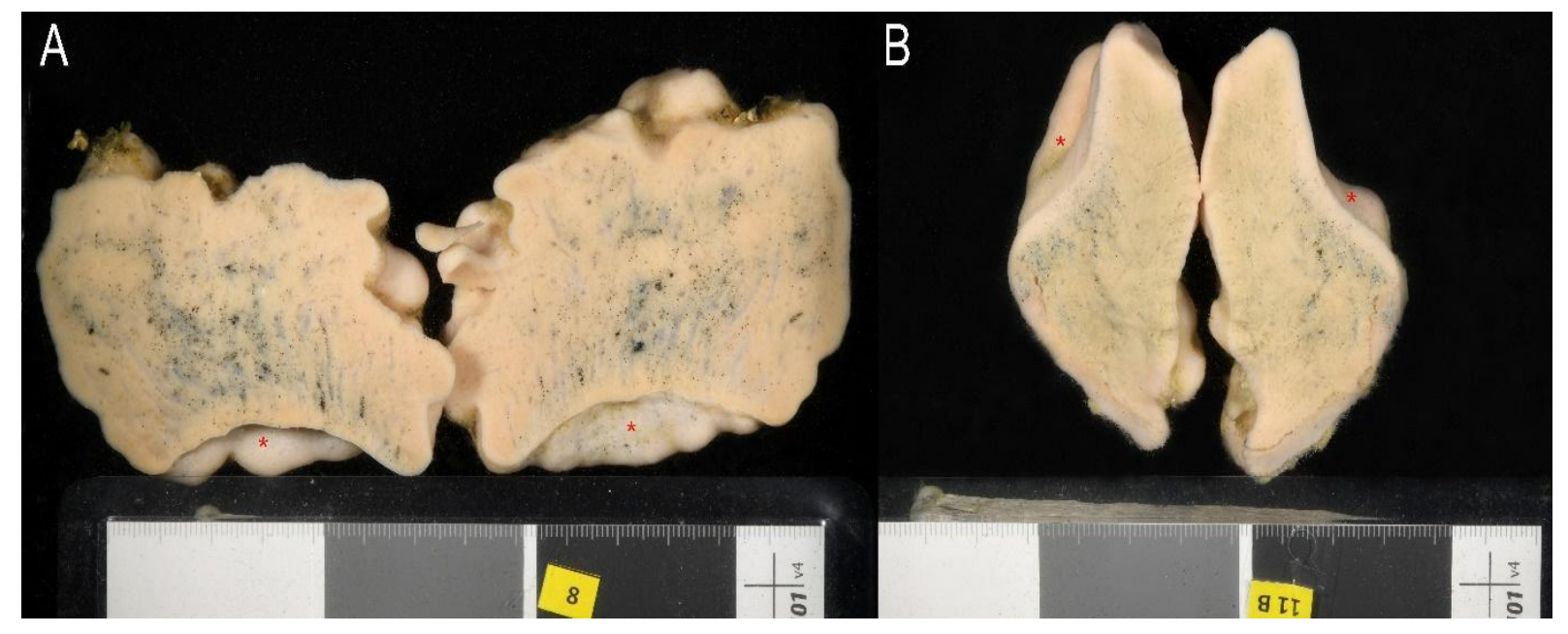

Figure 3.7. Transverse section images of sponge interior at $T_{14}$ showing sediment within a control sponge (A) and a sponge from the $500 \mathrm{mg}^{-1}$ treatment (B). Red asterisks indicate sponge upper surface.

Internal sediment grain sizes were larger than the sediment used in the experiment (e.g. up to 300-500 $\mu \mathrm{m}$; ImageJ). There was no significant difference between treatments in the inorganic content of the sponges $\left(\mathrm{F}_{(3,12)}=0.47, \mathrm{p}=0.7046\right.$, Table 3.2; Figure 3.8).

Table 3.2. Results of one-way ANOVA investigating the influence of the SSC treatment on Ecionemia novaezealandiae inorganic content. $\mathrm{DF}=$ degrees of freedom, $\mathrm{SS}=$ sum of squares, $\mathrm{MS}=$ mean square.

\begin{tabular}{llllll}
\hline & DF & SS & MS & F & $\operatorname{Pr}(>F)$ \\
\hline Treatment & 3 & 4.965 & 1.6549 & 0.47 & 0.7046 \\
Residuals & 12 & 41.693 & 3.4744 & & \\
\hline
\end{tabular}




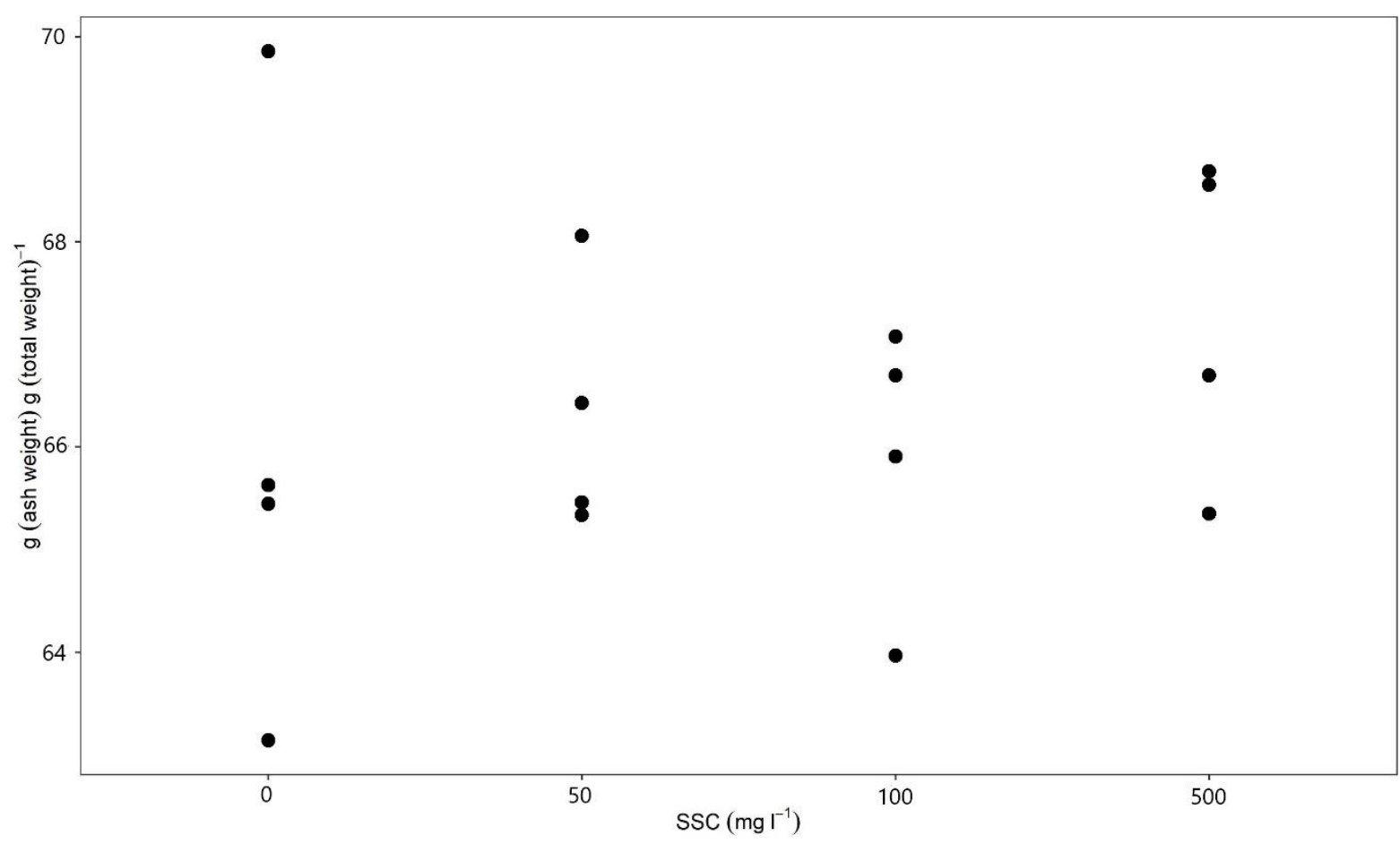

Figure 3.8. Scatterplot showing percentage of inorganic content of experimental sponges from each treatment. $\mathrm{N}=4$.

\subsection{Discussion}

Using a controlled laboratory experiment I investigated, for the first time, survival and physiological responses of the New Zealand deep-sea sponge Ecionemia novaezealandiae to acute (one day) and two week exposure to elevated suspended sediment concentrations. Despite the high survival, exposure to elevated SSCs had negative effects on this species, which included a reduction in respiration rates at both $\mathrm{T}_{1}$ and $\mathrm{T}_{14}$ and a decline in health, which manifested with partial necrosis at higher SSC at $\mathrm{T}_{14}$.

\subsubsection{Survival and health}

Survival was high, with one death occurring in the highest SSC treatment $\left(500 \mathrm{mg} \mathrm{l}^{-1}\right)$ after two weeks of sediment exposure. High survival rates have also been found in a shallow water New Zealand sponge exposed to elevated concentrations of natural sediment (up to $830 \mathrm{mg} \mathrm{l}^{-1}$ for 4 weeks; Chapter 2) and for Vazella pourtalesii over a three week period (Wurz et al., 2021). In contrast, Pineda et al. (2017) found elevated mortality rates (90\%) on a tropical shallow-water sponge exposed to $100 \mathrm{mg}^{-1} \mathrm{SSC}$, and low mortality rates at much lower SSCs 
(10 and $\left.30 \mathrm{mg}^{-1}\right)$. In that study, however, sponges were exposed to finely ground sediments (3-65 $\mu \mathrm{m})$ which differed from those in their natural environment (Pineda et al., 2017), unlike E. novaezealandiae, which was exposed to natural sediments. These contrasting findings confirm that sponge sensitivity to sediment is highly dependent on sediment properties, as well as sponge species.

The percentage of sponges affected by partial necrosis increased in the highest SSC treatments, as also observed in the tropical shallow-water sponges Carteriospongia foliascens, Cliona orientalis, and Coscinoderma matthewsi after exposure to 4 weeks of SSCs up to $100 \mathrm{mg} \mathrm{l}^{-1}$ (Pineda et al., 2017). Two of the six sponges with partial necrosis in my experiment (one control sponge and one sponge in the $100 \mathrm{mg}^{-1}$ treatment) had originated from the same donor sponge, so it is possible that this sponge was unhealthy at the start of the experiment. Similar low levels of necrosis have been reported in control sponges from other experiments where sponges were collected by divers (e.g. Biggerstaff et al., 2017) or by ROV (Wurz et al., 2021). The remaining four sponges exhibiting necrosis were from the $100 \mathrm{mg}^{-1}$ (1 sponge) or 500 $\mathrm{mg}^{-1}$ (3 sponges) treatments, indicating that the partial necrosis was due to the high SSC treatments.

\subsubsection{Respiration rates}

Respiration rates in E. novaezealandiae decreased with elevated SSCs, consistent with responses reported for the deep-sea sponges Geodia barretti and G. atlantica (Tjensvoll et al., 2013; Kutti et al., 2015; Scanes et al., 2018) and for some shallow water temperate (Aaptos spp.; Lohrer et al., 2006) and tropical sponges (Carteriospongia foliascens, Cliona orientalis, Stylissa flabelliformis; Pineda et al., 2017). Tjensvoll et al. (2013) and Kutti et al (2015) reported a $50 \%$ and $67 \%$ decline in respiration rate, respectively, in $G$. barretti after $4 \mathrm{~h}$ exposure of $500 \mathrm{mg}^{-1} \mathrm{SSC}$; similarly, E. novaezealandiae exposed to $500 \mathrm{mg}^{-1} \mathrm{SSC}$ had reduced its respiration rates by $60 \%$ at $\mathrm{T}_{1}$. The smaller variability in sponge respiration rates at $\mathrm{T}_{14}$ indicates that sponges may have adopted a strategy to cope with the SSCs. Wurz et al. (2021) reported a slight increase in respiration rates over a period of 21 days for Vazella pourtesii. This study is the first to expose deep-sea sponges to SSC $>50 \mathrm{mg} \mathrm{l}^{-1}$ for a period longer than a few hours, therefore the results obtained at $\mathrm{T}_{14}$ cannot be easily compared with other studies on deep-sea sponges. 
A reduction in oxygen consumption in response to sediment exposure has been linked to reduced or arrested pumping rates in order to prevent sediment from entering the sponge and clogging the aquiferous system (Gerrodette \& Flechsig, 1979; Bell et al., 2015). Pumping arrest or reduction has been widely observed in sponges as a response to sediment exposure (Tompkins-MacDonald and Leys, 2008; Gerrodette \& Flechsig, 1979; Grant et al., 2018; Grant et al., 2019; Reiswig, 1971; Strehlow et al., 2016). However, pumping is an essential process for sponges to obtain oxygen and food particles, and so a reduction/cessation of pumping in response to sediment may be initiated to prevent clogging of inhalant canals, and it is likely that reduced pumping activity impairs sponges feeding efficiency (see Lohrer et al., 2006 for discussion of reduction in sponge clearance rates). Although I was not able to directly assess E. novaezealandiae pumping activity, I propose that the lower respiration rates that were observed in high SSC treatments were due to a reduction in pumping rates. Along with decreased respiration rates, I observed internal necrosis in sponges exposed to SSC of 100 and $500 \mathrm{mg} \mathrm{l}^{-1}$, which could be a consequence of prolonged reduction in pumping. Hoffmann et al. (2008) described that during arrested pumping only a thin surface layer receives oxygen from molecular diffusion, and reduced or arrested pumping for a prolonged period could lead to partial necrosis due to the lack of oxygenation is some tissue portions.

In contrast to my observations, respiration rates in the shallow water tropical sponges Rhophaloeides orodabile and Xestospongia testudinaria increased in response to suspended sediments (Bannister et al. 2012; McGrath et al. 2017). Similarly, Biggerstaff et al. (2017) reported increased respiration rates in another shallow tropical sponge Lamellodysidea herbacea exposed to settled sediment. These species produced mucus when exposed to sediments for a short period (Bannister et al., 2012; Biggerstaff et al., 2017; McGrath et al., 2017), identified as a mechanism to trap sediment thus preventing smothering of inhalant pores (Bannister et al., 2012). Mucus production is likely to have high energetic demand, hence this would explain the increase in respiration rates (Bell et al., 2015). Mucus production by $E$. novaezealandiae was not observed in this experiment.

Although I could not directly measure sponge pumping, pre-experiment respiration trials showed that sponges were depleting oxygen, and therefore likely pumping. The respiration rates reported in control sponges were comparable, and even higher, than respiration rates reported in pumping specimens of the deep-sea sponge Geodia spp. In different experiments with Geodia spp., mean oxygen consumption rates of sponges from control conditions were $\sim 0.022 \mathrm{mg} \mathrm{h}^{-1} \mathrm{~g}^{-1}$ (DW) (Scanes et al., 2018), $0.054 \mathrm{mg} \mathrm{h}^{-1} \mathrm{~g}^{-1}$ (DW) (Kutti et al., 2015) and 
0.054-0.073 $\mathrm{mg} \mathrm{h}^{-1} \mathrm{~g}^{-1}$ (DW) (Tjensvoll et al., 2013). Mean oxygen consumption rates in our control sponges were $0.13-0.2 \mathrm{mg} \mathrm{h}^{-1} \mathrm{l}^{-1} \mathrm{~g}^{-1}$ (AFDW). If sponges were not pumping, oxygen consumption rates would have been expected to be much lower.

\subsubsection{Sediment incorporation}

Visual observations of sponge sections showed the presence of sediment inside the sponge tissues, although there was no correlation between the presence/amount of sediment accumulated and SSC treatment. This observation was corroborated by the absence of a relationship between sponge inorganic content (percentage of ash weight) and sediment treatments. Sponge inorganic content is made up of sponge spicules and, in this case, accumulated sediment. Assuming that sponge spicule content does not vary between treatments after such a short period, I expected that that any differences in sponge inorganic content would reflect sediment accumulation between treatments. However, as I did not separate spicules from sediment, I cannot rule this out. Accumulation of sediment in sponges exposed to sediments in experimental conditions has been shown in Crella incrustans (Chapter 2) and Ianthella basta (Strehlow et al. 2017), but only in sediment-treated sponges. In my study, several control sponges showed quantities of sediment similar to sponges from the SSC treatments. Sediments were dispersed in the sponge tissue, i.e. they were not located in a specific portion of the sponge. The presence of sediments in control sponges and their particle size indicates that these sediments had been accumulated in their natural environment. As sponges undergo continuous reorganization of tissues (Alexander, 2014), it is not possible to determine at which life stage they might have accumulated sediments. Some sponge species are known to actively take up and incorporate sediments and, in some cases, sediment incorporation can enhance growth and provide structural support (Schönberg 2016). Others also incorporate sand, larger particles and pebbles basally with the function of anchoring (Schönberg 2006 and references therein). It remains unknown if E. novaezealandiae passively or actively accumulates sediment internally (and if the latter, what the function of these sediments might be). A possibility is that the internal sediment was a result of the trawling disturbance during collection of the specimens. However, I believe this to be unlikely given that efforts were made to keep the trawl tows short (10-15 minutes on the bottom, 0.2-0.3 nautical miles length) and trawl speeds were low (1-1.5 knots to reduce disturbance of the seafloor sediments. Furthermore, if sponges had accumulated sediment during trawling, this sediment would have been expected close to the sponge surface, not scattered deeper internally 
(see Figure 3.6). In this study I observed a large quantity of sediments in control sponges seven weeks after their collection, however it is unknown how this amount compared with the immediate post-collection period. This might indicate that: a) these sponges were not able to clear the sediment they had internally accumulated or b) they actively incorporate sediment for one of the reasons described above.

\subsubsection{Sediment coverage}

Sediment settling out of suspension was deposited on the dorsal surfaces of the treatment sponges. Seabed images from an earlier survey on the Chatham Rise seafloor show widespread sediment coating on corals and sponges (Clark et al., 2018), suggesting that E. novaezealandiae may experience sediment deposition from the natural resuspension of seafloor sediments by bottom currents in the area (5-10 $\mathrm{cm} \mathrm{s}^{-1}$ recorded $2 \mathrm{~m}$ above the seafloor; Nodder et al., 2007) and hence that it might be tolerant to some levels of sediment deposition.

\subsection{Conclusions}

This study demonstrates that the deep-sea New Zealand sponge E. novaezealandiae has a rapid response to elevated SSC, with reduced respiration rates of up to $60 \%$ after just one day of sediment exposure. Despite the fact that the sediment concentrations used in my study were much higher than those used in most previous experiments on sponges for prolonged periods, only one mortality event was observed (albeit at the highest SSC). The presence of sediment particles incorporated within the control sponge tissues is evidence that this species is exposed to sediments in its natural environment. However, the sublethal effects I observed (necrosed tissues, decreased respiration rates) indicate increasing decline of sponge health at higher SSCs that may be potentially serious to the health of E. novaezealandiae beyond the experimental period, and may be exacerbated depending on the life stage at which the SSC exposure occurs. Tolerance of sponges to SSC is highly dependent on species, sediment quality, and location, thus caution is advised in generalising our conclusions from a two-week experiment to other deep-sea species and areas. 


\section{References}

Alexander, B.E., Liebrand, K., Osinga, R., van der Geest, H.G., Admiraal, W., Cleutjens, J.P., Schutte, B., Verheyen, F., Ribes, M., van Loon, E., de Goeij, J.M. (2014). Cell turnover and detritus production in marine sponges from tropical and temperate benthic ecosystems. PLoS One, 9, e109486.

Authority, N.Z.E.P. (2015). Decision on marine consent application by Chatham Rock Phosphate Limited to mine phosphorite nodules on the Chatham Rise. New Zealand Government.

Bannister, R.J., Battershill, C.N., De Nys, R. (2012). Suspended sediment grain size and mineralogy across the continental shelf of the Great Barrier Reef: Impacts on the physiology of a coral reef sponge. Continental Shelf Research, 32, 86-95.

Bell, J.J., 2008. The functional roles of marine sponges. Estuarine, Coastal and Shelf Science, 79, 341-353.

Bell, J.J., McGrath, E., Biggerstaff, A., Bates, T., Bennett, H., Marlow, J., Shaffer, M. (2015). Sediment impacts on marine sponges. Marine Pollution Bulletin, 94, 5-13.

Biggerstaff, A., Smith, D.J., Jompa, J., Bell, J.J. (2017). Metabolic responses of a phototrophic sponge to sedimentation supports transitions to sponge-dominated reefs. Scientific Reports, 7, $1-11$.

Black, J., Wood, R.A., Berthelsen, T., Tilney, R.L. (2013). Monitoring New Zealand's trawl footprint for deepwater fisheries: 1989-90 to 2009-10. Ministry for Primary Industries, Wellington, New Zealand.

Boschen, R.E., Rowden, A.A., Clark, M. R., Pallentin, A., Gardner, J.P.A. (2016). Seafloor massive sulfide deposits support unique megafaunal assemblages: implications for seabed mining and conservation. Marine Environmental Research, 115, 78-88.

Bowden, D.A., Davey, N., Fenwick, M., George, S., Macpherson, D., Ray, C., Stewart, R., Christensen-Field, C., Gibson, K. (2017). Quantifying Benthic Biodiversity: a factual voyage report from RV Tangaroa voyage TAN1701 to Chatham Rise. New Zealand Aquatic Environment and Biodiversity Report No. 185 (ISSN 1179-6480). Ministry for Primary Industries, Wellington, New Zealand. 
Bradshaw, C., Tjensvoll, I., Sköld, M., Allan, I.J., Molvaer, J., Naes, K., Nilsson, H.C. (2012). Bottom trawling resuspends sediment and releases bioavailable contaminants in a polluted fjord. Environmental Pollution, 170, 232-241.

Cathalot, C., Van Oevelen, D., Cox, T.J.S., Kutti, T., Lavaleye, M., Duineveld, G., Meysman, F.J.R. (2015). Cold-water coral reefs and adjacent sponge grounds: hotspots of benthic respiration and organic carbon cycling in the deep sea. Frontiers in Marine Science, 2, 37. doi:10.3389/fmars.2015.00037

Chu, J.W., Maldonado, M., Yahel, G., Leys, S.P. (2011). Glass sponge reefs as a silicon sink. Marine Ecology Progress Series, 441, 1-14.

Clark, M.R., \& Dunn, M.R. (2012). Spatial management of deep-sea seamount fisheries: balancing sustainable exploitation and habitat conservation. Environmental Conservation, 39, 204-214.

Clark, M.R., Nodder, S., O' Callaghan, J., Hickey, C., Chin, C., Eager, C., Elliot, F., Gammon, M., George, S., Gerring, P., Hart, A., Horst, T., Larsen, K., Leduc, D., Lennard, B., MacPherson, R., Mobilia, V., Pallentin, A., Price, O., Quinn, W., Ray, C., Stewart, R. (2018). Resilience of deep-sea benthic communities to the effects of sedimentation ("ROBES"): Voyage report of Survey 1: May-June 2018. Unpublished NIWA voyage report. 136 p. https://niwa.co.nz/sites/niwa.co.nz/files/ROBES VoyageReport 1Nov2018-web.pdf

Clark, M.R., Nodder, S., O'Callaghan, J., Browne, R., Daymond, A., de Joux, P., George, S., Hale, R., Hart, A., Jhugroo, K., Leduc, D., Mobilia, V., Price, O., Searson, S., Solomon, C., Stewart, R., Tracey, D. (2019). Resilience of deep-sea benthic communities to the effects of sedimentation (“ROBES”): Voyage report of Survey 2: June 2019. Unpublished NIWA voyage report. 74 p. https://niwa.co.nz/sites/niwa.co.nz/files/ROBES2_VoyageReport_2November2019NIWA.pdf

Clark, M.R., Althaus, F., Schlacher T. A, Williams, A., Bowden, D.A, Rowden, A.A. (2016). The impacts of deep-sea fisheries on benthic communities: a review. ICES Journal of Marine Science, 73, 151-169, https://doi.org/10.1093/icesjms/fsv123.

Deltares (2014). Modelling investigations on mine tailing plume dispersion on the Chatham Rise. Deltares Final Report 1209110-000-ZKS-0007, 57 pp. 
Durrieu de Madron X., Ferré, B., Le Corre, G., Grenz, C., Conan, P., Pujo-Pay, M., Buscail, R., Bodiot, O. (2005). Trawling-induced resuspension and dispersal of muddy sediments and dissolved elements in the Gulf of Lion (NW Mediterranean). Continental Shelf Research, 25, 2387-2409.

Ellis, J., Cummings, V., Hewitt, J., Thrush, S., Norkko, A. (2002). Determining effects of suspended sediment on condition of a suspension feeding bivalve (Atrina zelandica): results of a survey, a laboratory experiment and a field transplant experiment. Journal of Experimental Marine Biology and Ecology, 267, 147-174.

Ellis, J.I., Clark, M.R., Rouse, H.L., Lamarche, G. (2017). Environmental management frameworks for offshore mining: the New Zealand approach. Marine Policy, 84, 178-192.

FAO (2009). Report of the technical consultation on international guidelines for the management of deep-sea fisheries in the high seas. Rome, Italy: FAO. p. 98. Fisheries and Aquaculture Report No. 881.

Ferré, B., De Madron, X.D., Estournel, C., Ulses, C., Le Corre, G. (2008). Impact of natural (waves and currents) and anthropogenic (trawl) resuspension on the export of particulate matter to the open ocean: application to the Gulf of Lion (NW Mediterranean). Continental Shelf Research, 28, 2071-2091.

Fisheries New Zealand (2020): Fisheries Assessment Plenary, May 2020. Stock assessment and stock status.

Fosså, S.A., \& Nilsen, A.J. (1996). Korallenriff-Aquarium, Band 5. Einzellige Organismen, Schwa“mme, marine Würmer und Weichtiere im Korallenriff und für das KorallenriffAquarium. Kapittel 3: Schwämme. Bornheim: Birgit Schmettkamp Verlag, 35-65.

Gerrodette, T., \& Flechsig, A.O. (1979). Sediment-induced reduction in the pumping rate of the tropical sponge Verongia lacunosa. Marine Biology, 55, 103-110.

Glover A.G., Smith C.R. (2003). The deep-sea floor ecosystem: current status and prospects of anthropogenic change by the year 2025. Environmental Conservation, 30, 219-241.

Gollner, S., Kaiser, S., Menzel, L., Jones, D.O., Brown, A., Mestre, N.C., van Oevelen, D., Menot, L., Colaço, A., Canals, M., Cuvelier, D., Durden, M.J., Gebruk, A., Egho, A.G., Haeckel, M., Marcon, Y., Mevenkamp, L., Morato, T., Pham, C.K., Purser, A., Sanchez-Vidal, 
A., Vanreusel, A., Vink, A., Martinez Arbizy, P. (2017). Resilience of benthic deep-sea fauna to mining activities. Marine Environmental Research, 129, 76-101.

Grant, N., Matveev, E., Kahn, A.S., Archer, S.K., Dunham, A., Bannister, R.J., ErrkesMedrano, D., Leys, S.P. (2019). Effect of suspended sediments on the pumping rates of three species of glass sponge in situ. Marine Ecology Progress Series, 615, 79-100.

Grant, N., Matveev, E., Kahn, A.S., Leys, S.P. (2018). Suspended sediment causes feeding current arrests in situ in the glass sponge Aphrocallistes vastus. Marine Environmental Research, 137, 111-120.

Grove, S.L., Probert, P.K., Berkenbusch, K., Nodder, S.D. (2006). Distribution of bathyal meiobenthos in the region of the Subtropical Front, Chatham Rise, southwest Pacific. Journal of Experimental Marine Biology and Ecology, 330, 342-355.

Hall-Spencer, J., Allain, V., Fossa, J.H. (2002). Trawling damage to Northeast Atlantic ancient coral reefs. Proceedings of the Royal Society of London. Series B: Biological Sciences, 269, $507-511$.

Hewitt, J.E., \& Norkko, J. (2007). Incorporating temporal variability of stressors into studies: An example using suspension-feeding bivalves and elevated suspended sediment concentrations. Journal of Experimental Marine Biology and Ecology, 341, 131-141.

Hoffmann, F., Røy, H., Bayer, K., Hentschel, U., Pfannkuchen, M., Brümmer, F., De Beer, D. (2008). Oxygen dynamics and transport in the Mediterranean sponge Aplysina aerophoba. Marine Biology, 153, 1257-1264.

Hourigan, T.F., Etnoyer, P.J., Cairns, S.D. (2017). The state of deep-sea coral and sponge ecosystems of the United States. US Department of Commerce, National Oceanic and Atmospheric Administration, National Marine Fisheries Service.

Kahn, A.S., Yahel, G., Chu, J.W., Tunnicliffe, V., Leys, S.P. (2015). Benthic grazing and carbon sequestration by deep-water glass sponge reefs. Limnology and Oceanography, 60, 7888.

Kelly, M., \& Sim-Smith, C. (2012). A review of Ancorina, Stryphnus, and Ecionemia (Demospongiae: Astrophorida: Ancorinidae), with descriptions of new species from New Zealand waters. Zootaxa, 3480, 1-47. 
Klitgaard, A.B., \& Tendal, O.S. (2004). Distribution and species composition of mass occurrences of large-sized sponges in the northeast Atlantic. Progress in Oceanography, 61, $57-98$.

Kutti, T., Bannister, R.J., Fosså, J.H. (2013). Community structure and ecological function of deep-water sponge grounds in the Traenadypet MPA-Northern Norwegian continental shelf. Continental Shelf Research, 69, 21-30.

Kutti, T., Bannister, R.J., Fosså, J.H., Krogness, C.M., Tjensvoll, I., Søvik, G. (2015). Metabolic responses of the deep-water sponge Geodia barretti to suspended bottom sediment, simulated mine tailings and drill cuttings. Journal of Experimental Marine Biology and Ecology, 473, 64-72.

Lepland, A., Mortensen, P.B. (2008). Barite and barium in sediments and coral skeletons around the hydrocarbon exploration drilling site in the Træna Deep, Norwegian Sea. Environmental Geology, 56, 119-129. https://doi.org/10.1007/s00254-007-1145-4.

Levin, L.A., Mengerink, K., Gjerde, K.M., Rowden, A.A., Van Dover, C.L., Clark, M.R., Ramirez-Llodra, E., Currie, B., Smith, C.R., Sato, K.N., Gallo, N., Sweetman, A.K., Lily, H., Armstrong, C.W., Brider, J. (2016). Defining "serious harm" to the marine environment in the context of deep-seabed mining. Marine Policy, 74, 245-259.

Lohrer, A.M., Hewitt, J.E., Thrush, S.F. (2006). Assessing far-field effects of terrigenous sediment loading in the coastal marine environment. Marine Ecology Progress Series, 315, 1318.

Longo, C., Mastrototaro, F., Corriero, G. (2005). Sponge fauna associated with a Mediterranean deep-sea coral bank. Journal of the Marine Biological Association of the United Kingdom, 85, 1341-1352.

Maldonado M., Giraud K., Carmona C. (2008). Effects of sediment on the survival of asexually produced sponge recruits. Marine Biology, 154, 631-641.

Maldonado, M., Aguilar, R., Bannister, R.J., Bell, J.J., Conway, K.W., Dayton, P.K., Diaz, C., Gutt, J., Kelly, M., Kenchington, E.R., Leys, S.P, Pomponi S.A., Rapp, H.T., Rützler, K., Tendal, O.S., Vacelet, J., Young, C.M. (2017). Sponge grounds as key marine habitats: a synthetic review of types, structure, functional roles, and conservation concerns. Marine Animal Forests: The Ecology of Benthic Biodiversity Hotspots, 145-183. 
McGrath, E.C., Smith, D.J., Jompa, J., Bell, J.J. (2017). Adaptive mechanisms and physiological effects of suspended and settled sediment on barrel sponges. Journal of Experimental Marine Biology and Ecology, 496, 74-83.

Mengerink, K.J., Van Dover, C.L., Ardron, J., Baker, M., Escobar-Briones, E., Gjerde, K., Koslow, J.A., Ramirez-Llodra, E., Lara-Lopez, A., Squires, D., Sutton, A.K., Levin, L.A. (2014). A call for deep-ocean stewardship. Science, 344, 696-698.

Miller, D.C., Muir, C.L., Hauser, O.A. (2002). Detrimental effects of sedimentation on marine benthos: what can be learned from natural processes and rates? Ecological Engineering, 19, 211-232.

Murillo, F.J., Muñoz, P.D., Cristobo, J., Ríos, P., González, C., Kenchington, E., Serrano, A. (2012). Deep-sea sponge grounds of the Flemish Cap, Flemish Pass and the Grand Banks of Newfoundland (Northwest Atlantic Ocean): distribution and species composition. Marine Biology Research, 8, 842-854. doi:10.1080/17451000.2012.682583.

Nava, H., \& Carballo, J.L. (2013). Environmental factors shaping boring sponge assemblages at Mexican Pacific coral reefs. Marine Ecology, 34, 269-279.

Nodder, S.D., Duineveld, G.C.A., Pilditch, C.A., Sutton, P.J., Probert, P.K., Lavaleye, M.S.S., Witbaard, R., Chang, F.H., Hall, J.A., Richardson, K.M. (2007). Focusing of phytodetritus deposition beneath a deep-ocean front, Chatham Rise, New Zealand. Limnology and Oceanography, 52, 299-314.

NZ EPA (2015). Decision on Marine Consent Application Chatham Rock Phosphate Limited to Mine Phosphorite Nodules on the Chatham Rise. Available online at: https://cer.org.za/wpcontent/uploads/2016/08/EPA-New-Zealand-Chatham-Rock-Phosphate-Decision.pdf

Osinga, R., Tramper, J., Wijffels, R.H. (1999). Cultivation of marine sponges. Marine Biotechnology, 6, 509-532.

Palanques, A., Guillén, J., Puig, P. (2001). Impact of bottom trawling on water turbidity and muddy sediment of an unfished continental shelf. Limnology and Oceanography, 46, 11001110.

Parsons, D., Tuck, I., Jones, E., Baird, S., Bagley, N., Neil, H. (2013). Potential for sediment suspension from trawl activity on the Chatham Rise. NIWA Client Report No. WLG2013-61. 
Pham, C.K., Murillo, F.J., Lirette, C., Maldonado, M., Colaço, A., Ottaviani, D., Kenchington, E. (2019). Removal of deep-sea sponges by bottom trawling in the Flemish Cap area: conservation, ecology and economic assessment. Scientific Reports, 9, 1-13. https://doi.org/10.1038/s41598-019-52250-1.

Pile, A.J., \& Young, C.M. (2006). The natural diet of a hexactinellid sponge: benthic-pelagic coupling in a deep-sea microbial food web. Deep Sea Research Part I: Oceanographic Research Papers, 53, 1148-1156.

Pineda, M.C., Strehlow, B., Sternel, M., Duckworth, A., Jones, R., Webster, N.S. (2017). Effects of suspended sediments on the sponge holobiont with implications for dredging management. Scientific Reports, 7, 4925.

R Core Team (2020). R: A language and environment for statistical computing. R Foundation for Statistical Computing, Vienna, Austria. URL https://www.R-project.org/.

Ramirez-Llodra, E., Brandt, A., Danovaro, R., De Mol, B., Escobar, E., German, C.R., Levin, L.A., Martinez Arbizu, P., Menot, L., Buhl-Mortensen, P., Narayanaswamy, B.E., Smith, C.R., Tittensor, D.P., Tyler, P.A., Vanreusel, A., Vecchione, M. (2010). Deep, diverse and definitely different: unique attributes of the world's largest ecosystem. Biogeosciences, 7, 2851-2899. https://doi.org/10.5194/bg-7-2851-2010, 2010.

Ramirez-Llodra, E., Trannum, H.C., Evenset, A., Levin, L.A., Andersson, M., Finne, T.E., Hilaro, A., Flem, B., Christensen, G., Schaanning, M., Vanreusel, A. (2015). Submarine and deep-sea mine tailing placements: a review of current practices, environmental issues, natural analogs and knowledge gaps in Norway and internationally. Marine Pollution Bulletin, 97, 1335 .

Reiswig, H.M. (1971). In situ pumping activities of tropical Demospongiae. Marine Biology, $9,38-50$.

Rolinski, S., Segschneider, J., Sundermann, J. (2001). Long-term propagation of tailings from deep-sea mining under variable conditions by means of numerical simulations. Deep-Sea Research Part II: Topical Studies in Oceanography, 48, 3469-3485.

Scanes, E., Kutti, T., Fang, J.K., Johnston, E.L., Ross, P.M., Bannister, R.J. (2018). Mine waste and acute warming induce energetic stress in the deep-sea sponge Geodia atlantica and coral Primnoa resedeaformis; results from a mesocosm study. Frontiers in Marine Science, 5, 129. 
Schoellhamer, D.H. (1996). Anthropogenic sediment resuspension mechanisms in a shallow microtidal estuary. Estuarine, Coastal and Shelf Science, 43, 533-548.

Schönberg, C.H.L. (2016). Happy relationships between marine sponges and sediments-a review and some observations from Australia. Journal of the Marine Biological Association of the United Kingdom, 96, 493-514.

Smit, M.G.D., Holthaus, K.I.E., Trannum, H.C., Neff, J.M., Kjeilen-Eilertsen, G., Jak, R.G., Singsaas, I., Huijbregts, M.A.J., Hendriks, A.J. (2008). Species sensitivity distributions for suspended clays, sediment burial, and grain size change in the marine environment. Environmental Toxicology and Chemistry, 27, 1006-1012. doi:10.1897/07-339.1.

Strehlow, B.W., Jorgensen, D., Webster, N.S., Pineda, M.C., Duckworth, A. (2016). Using a thermistor flowmeter with attached video camera for monitoring sponge excurrent speed and oscular behaviour. PeerJ, 4, e2761.

Strehlow, B.W., Pineda, M.C., Duckworth, A., Kendrick, G.A., Renton, M., Wahab, M.A.A., Webster, N.S., Clode, P.L. (2017). Sediment tolerance mechanisms identified in sponges using advanced imaging techniques. PeerJ, 5, e3904.

Tjensvoll, I., Kutti, T., Fosså, J. H., Bannister, R.J. (2013). Rapid respiratory responses of the deep-water sponge Geodia barretti exposed to suspended sediments. Aquatic Biology, 19, 6573.

Tompkins-Mac Donald, G.J., Leys, S.P. (2008). Glass sponges arrest pumping in response to 48. sediment: implications for physiology of the hexactinellid conduction system. Marine Biology, 154, 973-984.

Tracey, D.M., Rowden, A.A., Mackay, K.A., Compton, T. (2011). Habitat-forming cold-water corals show affinity for seamounts in the New Zealand region. Marine Ecology Progress Series, $430,1-22$.

Xavier, J.R., Tojeira, I., Van Soest, R.W.M. (2015). On a hexactinellid sponge aggregation at the Great Meteor seamount (North-east Atlantic). Journal of the Marine Biological Association of the United Kingdom, 95, 1389-1394. 


\section{Chapter 4. Suspended sediment impact on the deep-sea coral Goniocorella dumosa}

\section{Abstract}

Human activities operating on the seafloor, such as bottom fishing and potential deep-sea mining, can generate sediment plumes posing threats to deep-sea benthic fauna. Corals are important components of deep-sea ecosystems and can be particularly sensitive to elevated suspended sediment concentrations. In this study, I exposed the deep-sea New Zealand deepsea coral Goniocorella dumosa (Alcock, 1902) (Class: Anthozoa; Family Caryophillidae) to four-day pulses of four target sediment concentrations $\left(0,50,100\right.$ and $\left.500 \mathrm{mg} \mathrm{l}^{-1}\right)$. All coral fragments survived. Oxygen consumption rates were elevated in the 100 and $500 \mathrm{mg}^{-1} \mathrm{SSC}$ treatment corals compared to control and $50 \mathrm{mg} \mathrm{l}^{-1}$ treatment corals after one sediment pulse, however, this response did not persist after the second and third sediment pulse cycle. No visible detrimental effects were recorded after the first pulse of sediment exposure, while partial coenosarc loss and partial polyp mortality affected some treatment corals fragments during the following sediment pulses, although these effects were not statistically significant. Despite coral survival not being affected during the length of my experiment, the decline of health conditions over time indicates that $G$. dumosa could sustain intense sediment disturbance from intense human activities for periods up to 4 days, but repeated, and, likely, prolonged sediment exposure will increasingly deteriorate its health condition.

\subsection{Introduction}

Offshore bottom fisheries and industries focused on deep-sea regions, such as oil drilling, cable laying, and mineral exploration, have been increasing in recent decades (Glover and Smith, 2003; Ramirez-Llodra et al., 2015). These activities pose a number of threats to deep-sea ecosystems as they generally lead to removal of the substrate and associated fauna, and to the modification of seabed morphology. Such anthropogenic disturbance can drastically impact benthic communities and lead to habitat modification or even complete loss (e.g., see Clark et al. 2016; Levin et al., 2016).

Among deep-sea fauna, of particularly importance are deep-sea corals. Globally deep-sea corals, also referred to as cold-water corals, are found at temperatures between 4 and $12{ }^{\circ} \mathrm{C}$ and most commonly between 200 and 2000 m depth (Freiwald et al., 2004; Roberts et al., 2006). 
Several deep-sea coral groups can create large, complex, and fragile habitats. These habitats (coral reefs and gardens) provide important ecosystem services for fish and invertebrates (e.g. areas to aggregate for feeding and spawning; refugia for juveniles), and support high abundance and diversity (Etnoyer et al., 2004; Buhl-Mortensen \& Mortensen, 2004; Roberts et al., 2004; Roberts et al., 2006).

Deep-sea corals are generally slow growing and fragile, characteristics that make them extremely vulnerable to anthropogenic-induced seafloor disturbances (Roberts et al., 2009, Clark et al., 2010; Clark et al., 2016). Deep-sea coral gardens can be heavily damaged by ongoing (fisheries, oil and gas exploitation) and emerging (mining) industries (NOAA, 2010). Because of their vulnerability and importance to/in deep-sea ecosystems, deep-sea coral habitats have been classified as Vulnerable Marine Ecosystems (VMEs) by the United Nations General Assembly (UNGA) Resolution 61/105 (FAO, 2009), and should be subject to conservation actions where necessary.

Destruction of deep-sea coral reefs by bottom-trawling activities has been well documented in Norway (Armstrong and van den Hove, 2008; Henry et al., 2013), Florida (NOAA, 2010) and Ireland (Foley et al., 2011). In New Zealand, Clark et al. (2010) found that coral coverage decreased significantly where fishing effort was high on small seamounts along ridges, and that dense colonies of scleractinian corals were found only on ridges where the seabed is too rough for bottom trawling, implying that fishing activities were responsible for reducing coral presence in areas exposed to high fishing effort.

In addition to the physical damage, bottom fishing and proposed deep-sea mining activities can generate sediment plumes and deposits, which could lead to burial and smothering of benthic fauna, including corals (Hall-Spencer et al., 2002; Boschen et al., 2016, Clark et al., 2016). These activities can disturbe several centimetres into the seafloor and can re-suspend bottom sediments into the water column. Suspended sediments may reach concentrations up to $500 \mathrm{mg}$ $1^{-1}$, and can form plumes that can extend over hundreds of kilometers depending on local hydrodynamic conditions (Schoellhamer 1996; Durrieu de Madron et al., 2005; Bradshaw et al., 2012, Parsons et al., 2013). Larger sediment particles can settle quickly, while fine particles can remain in suspension for long periods (from days to weeks; Lepland and Mortensen, 2008). Intense fishing practises and deep-sea mining operations can, therefore, contribute substantially to sediment resuspension and sediment transport in areas where natural sediment suspension is generally low (Ferré et al. 2008), potentially causing severe and long-lasting effects on corals 
and their associated benthic communities (Miller et al., 2002; Gollner et al. 2016). Currently, we know very little about these sedimentation effects on deep-sea corals.

The New Zealand Exclusive Economic Zone (EEZ) contains large volumes of oil, mineral and gas resources that have considerable economic potential, with seafloor mineral deposits alone having an estimated value of $~ 500$ billion NZD (Ellis et al., 2017). In 2015, a marine consent application to mine phosphorite nodules on the top of the Chatham Rise (north east New Zealand) was declined by New Zealand Environmental Protection Authority (NZ EPA) due in part to uncertainty about the nature and the extent of adverse effects (including effects of suspended and settled sediments) on biological communities (NZ EPA, 2015). The predicted peak suspended sediment concentrations derived from mining plumes, on the Chatham Rise, are $100 \mathrm{mg} \mathrm{l}^{-1}$ inside the potential mining areas $\left(2 \mathrm{~km}\right.$ wide and $5 \mathrm{~km} \mathrm{long}$ ) and $50 \mathrm{mg} \mathrm{1^{-1 }}$ outside the potential mining areas (Deltares, 2014). Together with the Chatham Rise being an important area for New Zealand fisheries (with almost 50\% of the total EEZ area trawled shallower than $1000 \mathrm{~m}$; Baird et al., 2013), there is a strong need to assess potential impacts of sediments on deep-sea species to help inform management of such activities. The Resilience of deep-sea benthic communities to the effects of sedimentation programme (ROBES, 2016-2020) was recently initiated to investigate these questions using a combination of field observations and laboratory experiments.

New Zealand deep-sea waters contain an abundant and diverse coral fauna, primarily comprised of scleractinian stony corals (Cairns 1995; Cairns 2012). The New Zealand EEZ hosts about $16 \%$ of the scleractinian corals found worldwide (Cairns et al., 2007). One common scleractinian coral in the New Zealand deep-sea region is the bushy habitat forming Goniocorella dumosa (Alcock, 1902). This species occurs between 400 and $900 \mathrm{~m}$ depth, most commonly on seamount slopes and rises, including the top of the Chatham Rise (Cairns 1995; Tracey et al., 2007; Tracey et al., 2011) (Figure 4.1). 


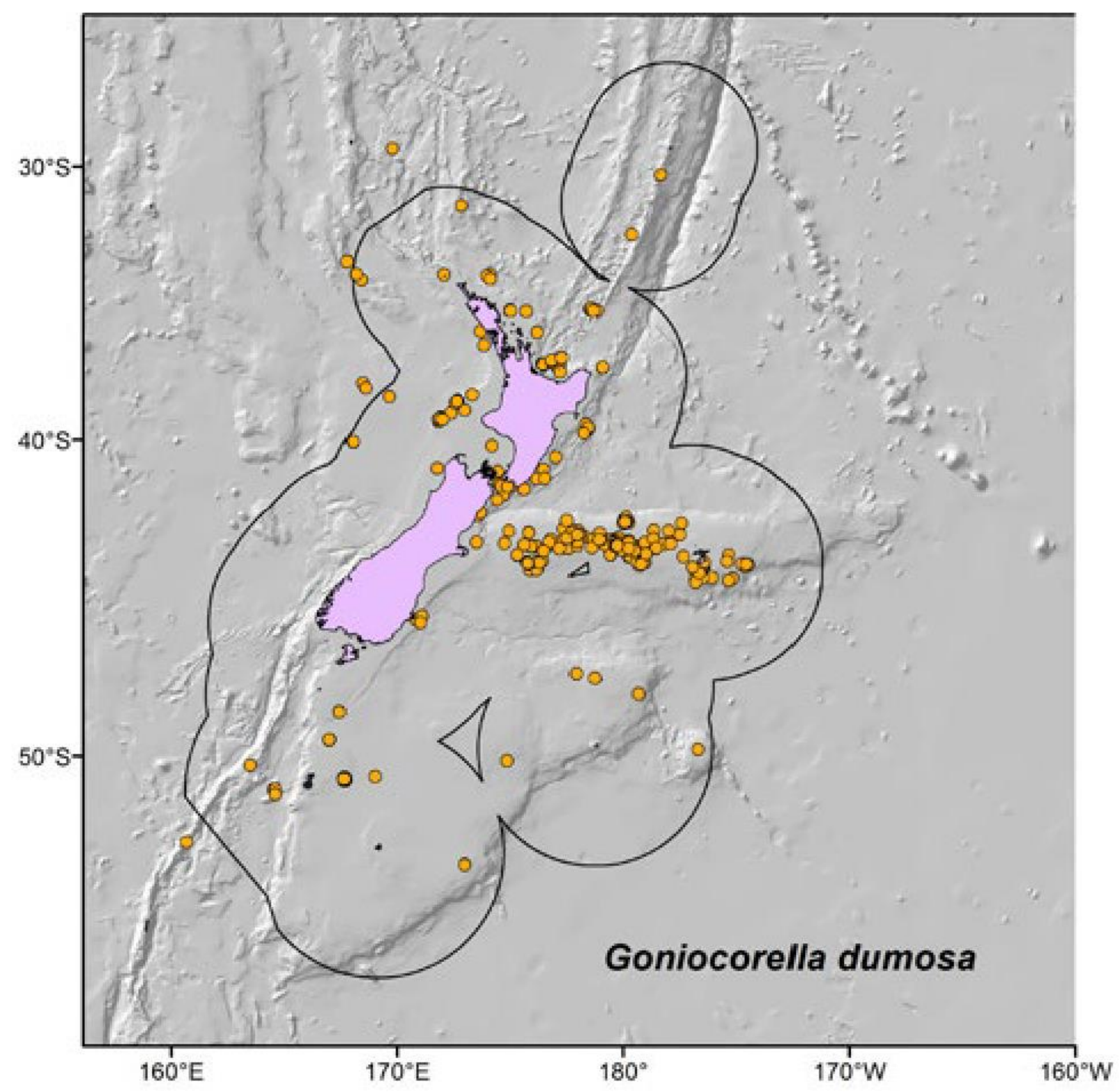

Figure 4.1. Distribution map of Goniocorella dumosa around New Zealand waters (yellow dots). Figure taken from Tracey et al. (2019).

Knowledge of the impacts of sedimentation on deep-sea corals is still very limited. Six studies have investigated impacts on the Northern Hemisphere species Lophelia pertusa (Brooke et al., 2009; Larsson and Purser, 2011; Allers et al., 2013; Larsson et al., 2013, Järnegren and Kutti, 2017; Baussant et al., 2018) and one study on the alcyonacean gorgonian octocoral Primnoa resedaeformis (Scanes et al., 2018). Brooke et al. (2009) found >90\% L. pertusa polyps died after exposure to 14 days of high suspended sediment concentrations ( $\left.\sim 360 \mathrm{mg}^{-1}\right)$ and after four days of complete burial. Similarly, Allers et al. (2013) found coral mortality after exposure to complete burial for 2 and 3 days, while no detrimental effects were detected within $<12$ days of partial sediment coverage. Sub-lethal effects of natural sediments and drill-cutting 
sediment on $L$. pertusa include reduced growth and larval survival (Larsson et al., 2013; Järnegren and Kutti, 2017) and loss of coenosarc tissue (also known as coenenchyme; Larsson and Purser, 2011).

Corals are important components of New Zealand deep-sea ecosystems, and there is need for more information on how they might be impacted from seafloor disturbance. The aim of this study, as part of the ROBES programme, was to assess the physiological response of Goniocorella dumosa to elevated suspended sediment concentrations arising from resuspension of benthic sediments, and their recovery ability in the short term.

\subsection{Materials and Methods}

\subsubsection{Corals collection and maintenance}

In June 2019, G. dumosa samples were collected by beam trawl from $\sim 400 \mathrm{~m}$ on the Chatham Rise during a National Institute of Water and Atmospheric Research (NIWA) voyage onboard RV Tangaroa (Clark et al., 2019). Temperature was recorded in situ with a conductivity, temperature and depth (CTD) profiler. Corals from the trawl were placed immediately into cooled seawater $\left(9^{\circ} \mathrm{C}\right.$, the temperature at the sampling site) and transferred into a dark, flowthrough system with fresh, cooled to $9{ }^{\circ} \mathrm{C}$ seawater, filtered to $1 \mathrm{~mm}$. At the end of the voyage, circa 5 days post collection, corals were transferred to the Marine Environmental Manipulation Facility (MEMF) at NIWA Wellington. Here, corals were held in the dark, in flow-through holding tanks with fresh seawater (filtered to $0.1 \mu \mathrm{m}$ ) at temperatures similar to those at the collection site $\left(9^{\circ} \mathrm{C}\right)$. Any epibionts were removed from the coral surfaces so to not affect their responses to the experimental treatments (i.e. respiration rates). Corals were fed three times per week with the commercial product JBL Korall Fluid. They were left undisturbed for four months to settle and acclimate before the experiment began. Sixty-four coral fragments, each containing at least six live polyps were selected for the experiment, and were attached in an upright position with cable ties onto individual plastic mesh bases $(\sim 4 \mathrm{x} 4 \mathrm{~cm})$. Immediately prior to the start of the experiment, all fragments were photographed, and randomly distributed amongst 16 experimental chambers $(\mathrm{N}=4$ per chamber; methods detailed below). They were left to acclimate for $24 \mathrm{~h}$ before sediment was added to the chambers. 


\subsubsection{Sediment treatments}

Coral fragments were exposed to four different concentrations of suspended sediment (SSCs): $0,50,100,500 \mathrm{mg} \mathrm{l}^{-1}$, with $\mathrm{N}=4$ replicate experimental chambers for each treatment. The SSCs were chosen to include those predicted from models investigating mine plume dispersion on the Chatham Rise (50-100 $\mathrm{mg} \mathrm{l}^{-1}$ ) and empirically-derived concentrations of sediments resuspended by bottom-trawling activities (up to $500 \mathrm{mg} \mathrm{l}^{-1}$ ). Corals were exposed to SSC for four days, followed by five days without sediment addition. This cycle was repeated three times, simulating intermittent mining operations or bottom-contact fishing activities, for a total experiment length of 27 days.

\subsubsection{Sediment collection and manipulation}

Seafloor sediments $(3-150 \mu \mathrm{m})$ were collected from the Chatham Rise using a MC-800 multicorer (an instrument with multiple $10 \mathrm{~cm}$ diameter core barrels). The top $5 \mathrm{~cm}$ of the sediment column were used for the experiment, as this surface layer is most likely to be disturbed and resuspended into the water column by bottom-contact fishing and mining activities (Palanques et al., 2001). Sediments were frozen at $-20{ }^{\circ} \mathrm{C}$ to kill any living fauna. Prior to use in the experiment, sediment samples were thawed and dried at $100{ }^{\circ} \mathrm{C}$ overnight, then sieved through a $150 \mu \mathrm{m}$ mesh. Target suspended sediment concentrations were obtained by manually adding a sediment slurry (dried sediment mixed with seawater) to each experimental chamber.

SSCs in the chambers were monitored twice daily using a hand-held Seapoint Turbidity meter connected to a multimeter which displayed millivolts $(\mathrm{mV})$. The relationship between suspended sediment concentrations (SSCs) and optical turbidity $(\mathrm{mV})$ had been determined prior to the experiment for a large range of concentrations (Figure A4.1). When the $\mathrm{mV}$ reading from the turbidity meter was lower than the target $\mathrm{mV}$, additional sediment was added manually to the chambers. The amount of sediment added was determined by the difference between the target SSC and the voltage reading, using the calibration curve shown in Figure A4.1. Suspended sediment concentrations in each chamber were also determined gravimetrically from water samples collected during each sediment cycle. Three aliquots of $50 \mathrm{ml}$ were sampled from each chamber and filtered through pre-dried $\left(60^{\circ} \mathrm{C}\right)$ and pre-weighed $25 \mathrm{~mm}$ $\mathrm{GF} / \mathrm{F}$ (Whatman) filters and dried to a constant weight at $60{ }^{\circ} \mathrm{C}$. 
The experimental chambers used to keep the sediment at target concentrations were the same used in Chapter 3.

\subsubsection{Coral responses}

Coral fragments were sampled at the end of each four-day sediment cycle $\left(T_{1}, T_{2}, T_{3}\right)$ and at the end of the last five-day period without sediment ( $\mathrm{T}_{4}$; Figure 4.2$)$; this corresponded to 4 $\left(\mathrm{T}_{1}\right), 13\left(\mathrm{~T}_{2}\right), 22\left(\mathrm{~T}_{3}\right)$ and $27\left(\mathrm{~T}_{4}\right)$ days from the start of the experiment. At each sampling time point, one coral fragment per chamber was removed, and sacrificed (Fig 4.2), for respiration rate measurements, after which digital images were taken to obtain counts of live polyps and assess tissue loss. Coral fragments were frozen $\left(-20^{\circ} \mathrm{C}\right)$ for later determination of dry weight and ash free dry weight (AFDW).

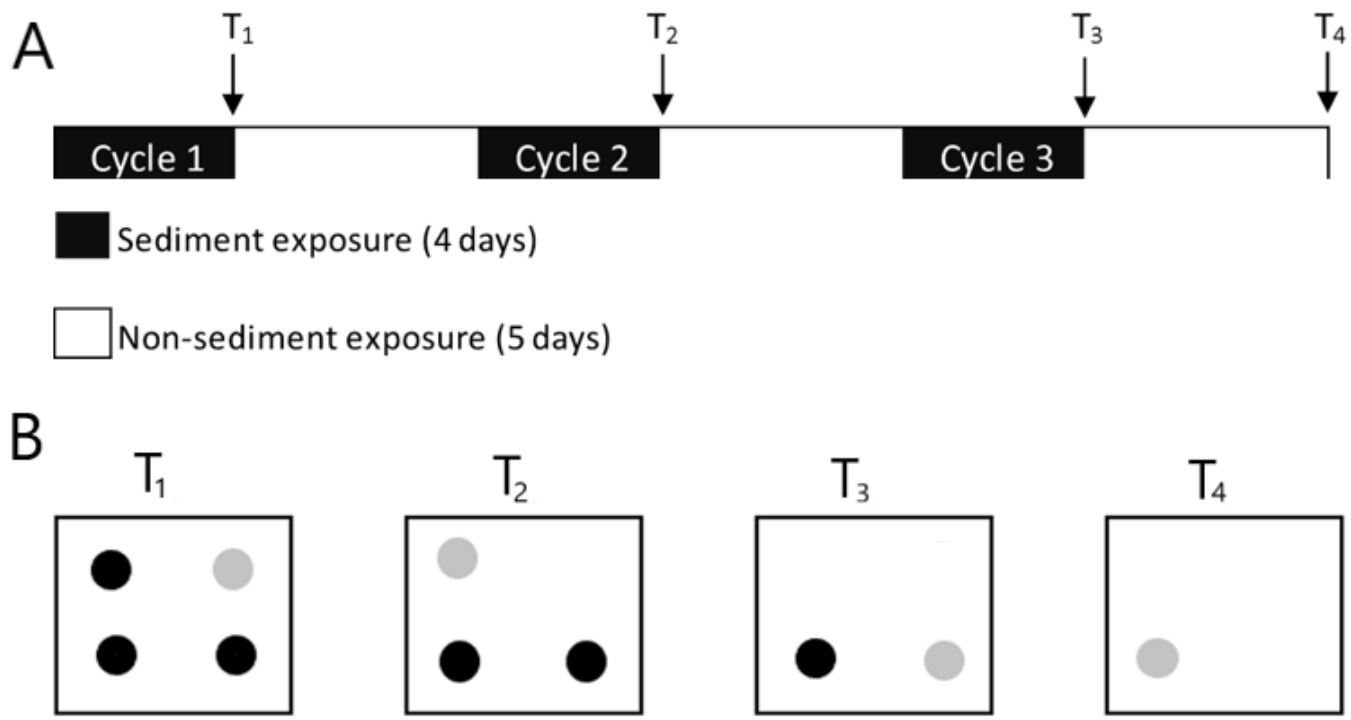

Figure 4.2. Schematic of the experiment showing the sediment exposure regime with 3 cycles of four-days sediment exposure alternated with five days of non-sediment exposure periods (A), and representation of the coral sampling design (B). Squares represent sediment chambers 
and dots represent coral fragments inside the chambers, grey dots represent coral fragments sacrificed at each sampling time point $(B) . T_{1}, T_{2}, T_{3}$ and $T_{4}$ indicate sampling time points.

\subsubsection{Respiration Rates}

Respiration rates were measured in sealed $300 \mathrm{ml}$ respiration chambers with precalibrated PreSens oxygen spots attached to the inner surfaces. Mixing of the chamber water was achieved using a magnetic stir bar located in a separate compartment at the bottom of each chamber. The respiration chambers were immersed in a flow-through water bath to maintain constant water temperature $\left(\sim 9^{\circ} \mathrm{C}\right)$.

Coral fragments were added to the respiration chambers and acclimated for 30 minutes to make sure that their polyps were extended. After acclimation, the respiration chambers were sealed and initial dissolved oxygen (DO) readings were taken. The incubation was carried out in the dark for 16 hours. The incubation time was determined from preliminary trials using spare coral fragments, which showed oxygen consumption was low. Oxygen concentration inside the chamber did not drop below $70 \%$ saturation over this time period. Blank incubation chambers containing only seawater were used to correct for any microbial community respiration in the seawater. Respiration rates ( $\mathrm{mg} \mathrm{O}_{2} \mathrm{~h}^{-1} \mathrm{l}^{-1} \mathrm{~g}^{-1}$ AFDW) were determined after adjusting for the volume of the water in the chamber and the coral AFDW. AFDW was determined by oven drying the samples $\left(60^{\circ} \mathrm{C}\right)$ to constant weight, and ashing $\left(500{ }^{\circ} \mathrm{C}\right.$ for $\left.5 \mathrm{~h}\right)$. Respiration rates were also normalized for the polyp number, however, I report only the respiration rates normalized for AFDW as the correlation between corals AFDW and polyp number was not strong $\left(R^{2}=0.61\right.$; Figure S4.2).

\subsubsection{Polyp mortality and coenosarc loss}

Digital images of the corals were taken using a Nikon D850 camera (50 mm lens) prior to the experiment start $\left(\mathrm{T}_{0}\right)$ and at each sampling time point, after respiration rate measurements. Digital images at each sampling time point were compared to the ones taken at $\mathrm{T}_{0}$ and analysed with the software ImageJ. Counts of the number of live polyps (to assess polyp mortality) and estimates of the percentage of coenosarc tissue covering the coral fragments were made. Coenosarc loss $(\%)$ was calculated subtracting the $\%$ coenosarc covering the skeleton at each 
sampling time point from the $\%$ coenosarc at $\mathrm{T}_{0}(100 \%)$. A scale and grey colour bar were included in the photographs to aid the comparisons.

\subsubsection{Statistical analysis}

The effects of treatment and time on coral respiration rates were tested. Normality of the residuals' assumption was met (after testing with Shapiro Wilk's test). Heterogeneity of variance of the residual assumption was not met (Levene's test), even after data transformation, thus I combined the factors 'treatment' and 'time' (i.e. Treatment*Time, $\mathrm{N}=16$ ) and reduced the analysis to a one-way Welch ANOVA, which does not require homogeneity of variance of the residuals. The effects of time and treatment were examined on the proportion of coenosarc loss in the corals that showed a response. As the percentage of coral fragments not affected by coenosarc loss was high, resulting in zero-inflation, the factors' effects were investigated only on the responsive corals using a linear regression model. Normality and homogeneity of variance of the residuals were tested (Shapiro Wilk and Levene's test, respectively). Statistical analyses were performed in $\mathrm{R}$ version 3.6.3 ( $\mathrm{R}$ core team, 2020).

\subsection{Results}

\subsubsection{Polyp survival}

Overall, no whole-fragment mortality was detected throughout the experiment. No polyp mortality occurred in control corals. At $\mathrm{T}_{2}$, one polyp (2.04\%) was dead in one out of four 100 $\mathrm{mg} \mathrm{l}^{-1} \mathrm{SSC}$ coral fragment and two polyps $(2.66 \%)$ were dead on two out of four $500 \mathrm{mg} \mathrm{l}^{-1}$ SSC corals (one dead polyp on each of the two fragments). At $\mathrm{T}_{3}$, two polyps (3.2\%) were found dead on two out of four corals in the $500 \mathrm{mg}^{-1}$ SSC treatment (one dead polyp on each of the two fragments). At $\mathrm{T}_{4}, 1$ polyp (1.7\%) was dead in one of the $50 \mathrm{mg}^{-1}$ coral fragment, 1 polyp $(1.7 \%)$ was dead in 1 out of 4 corals in the $100 \mathrm{mg}^{-1} \mathrm{SSC}$ treatment and 4 polyps $(5.33 \%)$ were dead in 2 out of 4 corals in the $500 \mathrm{mg} \mathrm{l}^{-1}$ (one and three dead polyps on the two fragments) (Table 4.1). As polyp mortality rates were low, no statistical analysis was performed. The calyces containing dead polyps were filled with sediment (Figure 4.3, 4.5). The calyces containing dead polyps were filled with sediment (Figures 4.3, 4.5). 
Table 4.1. Total number of polyps and number of dead polyps in each of the sediment concentration treatment $\left(0,50,100,500 \mathrm{mg} \mathrm{l}^{-1}\right)$ at each sampling time point $\left(\mathrm{T}_{1}, \mathrm{~T}_{2}, \mathrm{~T}_{3}, \mathrm{~T}_{4}\right)$.

\begin{tabular}{|c|c|c|c|c|c|c|c|c|c|c|c|c|c|c|c|c|}
\hline & \multicolumn{4}{|c|}{$T_{1}$} & \multicolumn{4}{|c|}{$T_{2}$} & \multicolumn{4}{|c|}{$T_{3}$} & \multicolumn{4}{|c|}{$T_{4}$} \\
\hline & \multicolumn{16}{|c|}{ SSCs } \\
\hline & 0 & 50 & 100 & 500 & 0 & 50 & 100 & 500 & $\mathbf{0}$ & 50 & 100 & 500 & 0 & 50 & 100 & 500 \\
\hline Total polyp no. & 75 & 69 & 59 & 54 & 89 & 81 & 49 & 75 & 48 & 89 & 70 & 62 & 67 & 63 & 58 & 75 \\
\hline Dead polyp no. & - & - & - & - & - & - & 1 & 2 & - & - & - & 2 & - & 1 & 1 & 4 \\
\hline
\end{tabular}

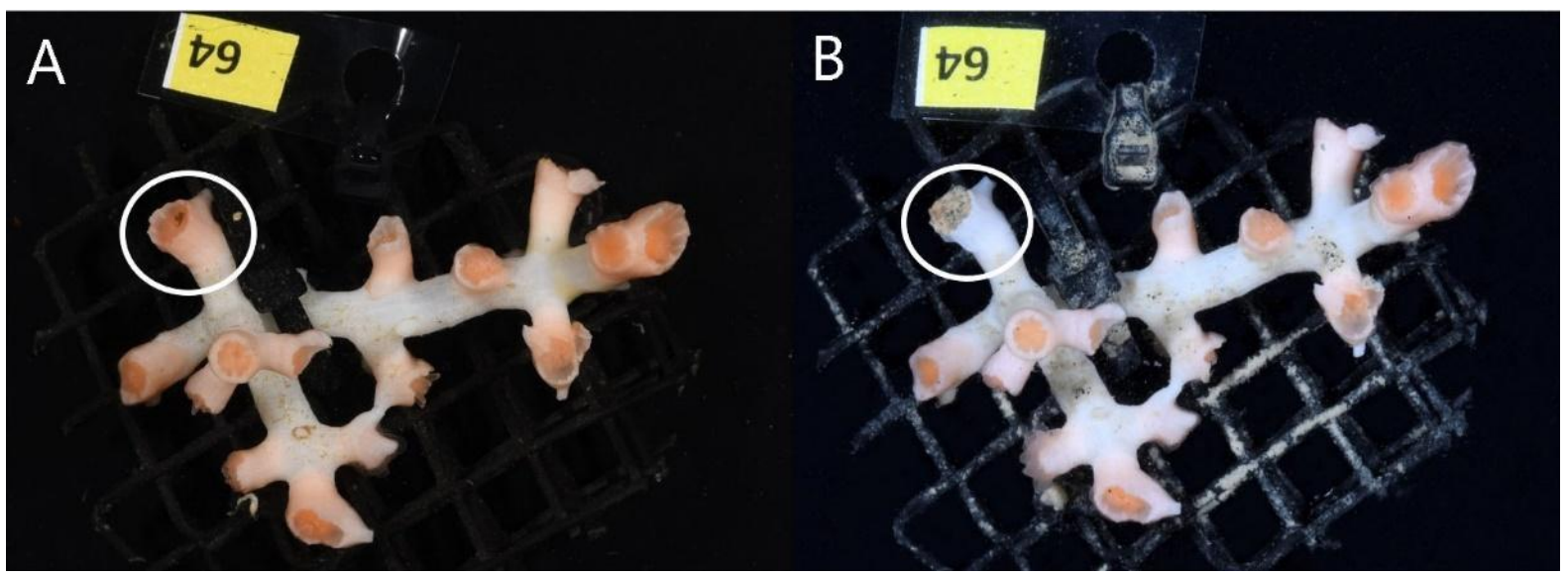

Figure 4.3. Image of Goniocorella dumosa fragment in the $500 \mathrm{mg} \mathrm{l}^{-1} \mathrm{SSC}$ treatment at $\mathrm{T}_{0}(\mathrm{~A})$ and at $\mathrm{T}_{2}$ (B). White circles indicate a healthy (A) and dead polyp filled with sediment (B).

\subsubsection{Coenosarc loss}

Partial coenosarc loss was observed in $23 \%$ of corals over the experiment. Only one control coral fragment showed coenosarc loss $\left(13 \%\right.$, at $\left.\mathrm{T}_{3}\right)$, and no corals exhibited coenosarc loss at $\mathrm{T}_{1}$. However, $31 \%$ of the coral fragments were affected at each of the following sampling time points (Figure 4.4). The effects of time and treatment on the percentage of coenosarc loss were not significant, and there was no significant interaction of treatment and time (Table 4.2). However, the power of this analysis was low as there were few responsive coral fragments $(\mathrm{N}$ =15). At $\mathrm{T}_{2}, 2$ corals in the $100 \mathrm{mg} \mathrm{l}^{-1} \mathrm{SSC}$ treatment and 3 corals in the $500 \mathrm{mg}^{-1} \mathrm{SSC}$ treatment had coenosarc loss; at $\mathrm{T}_{3}$, one control fragment, one fragment in the $50 \mathrm{mg}^{-1} \mathrm{SSC}$ treatment and 3 fragments in the $500 \mathrm{mg}^{-1} \mathrm{SSC}$ treatment had coenosarc loss; at $\mathrm{T}_{4}, 2$ coral fragments in the $50 \mathrm{mg} \mathrm{l}^{-1} \mathrm{SSC}$ treatment, one fragment in the $100 \mathrm{mg}^{-1} \mathrm{SSC}$ treatment and 2 fragments in the $500 \mathrm{mg}^{-1} \mathrm{SSC}$ treatment had partial coenosarc loss. In coral fragments with dead polyps ( $n=9)$, coenosarc loss was associated with these dead polyps. In all the other corals 
where coenosarc loss occurred $(\mathrm{N}=6)$ the polyps were alive. The $500 \mathrm{mg} \mathrm{l}^{-1} \mathrm{SSC}$ treatment had the highest number of corals affected by coenosarc loss, and the highest percentage of tissue loss at all sampling time points.

Table 4.2. ANOVA table and summary of Linear Regression Model assessing the effects of SSC and Time on the percentage of coenosarc loss on responsive Goniocorella dumosa fragments. $\mathrm{DF}=$ degrees of freedom, $\mathrm{SS}=$ sum of square, $\mathrm{MS}=$ mean squares.

\begin{tabular}{llllll}
\hline & DF & SS & MS & F & $\operatorname{Pr}(>F)$ \\
\hline SSC & 2 & 0.019 & 0.0095 & 1.6802 & 0.2535 \\
Time & 3 & 0.0227 & 0.0075 & 1.3375 & 0.337 \\
SSC*Time & 2 & 0.0344 & 0.0172 & 3.0397 & 0.1121 \\
Residuals & 7 & 0.0397 & 0.0056 & & \\
\hline
\end{tabular}

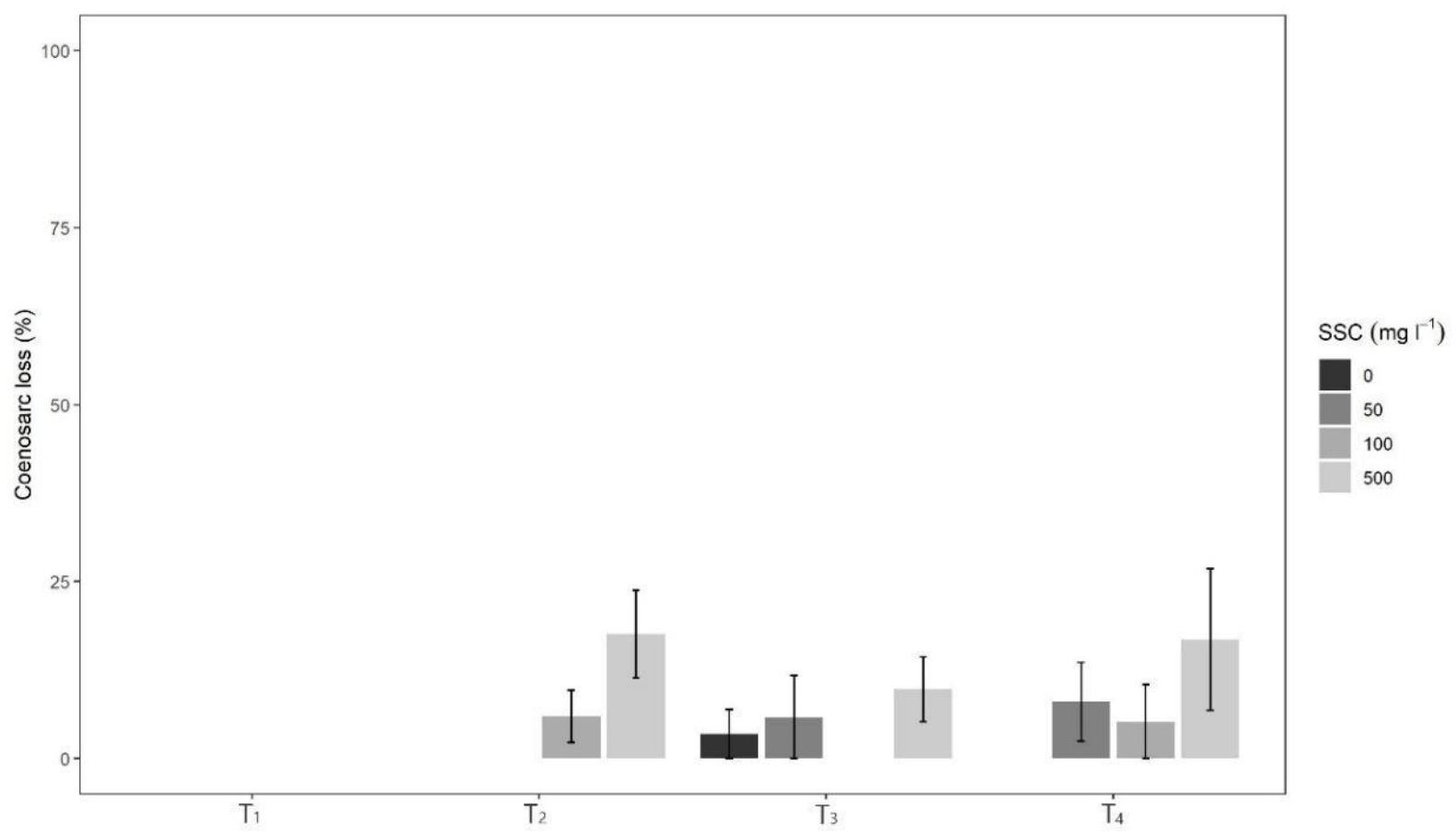

Figure 4.4. Percentage of coenosarc loss (\%) in Goniocorella dumosa in each of the suspended sediment concentration (SSC) treatments at each sampling time point $\left(\mathrm{T}_{1}=4, \mathrm{~T}_{2}=13, \mathrm{~T}_{3}=22\right.$, $\mathrm{T}_{4}=27$ days). Bars show mean values $( \pm \mathrm{SE}) . \mathrm{N}=4$.

Partial loss of coenosarc tissue covering the skeleton was observed both along with dead polyps (Figure 4.5) and in coral fragments where no polyp mortality occurred. 


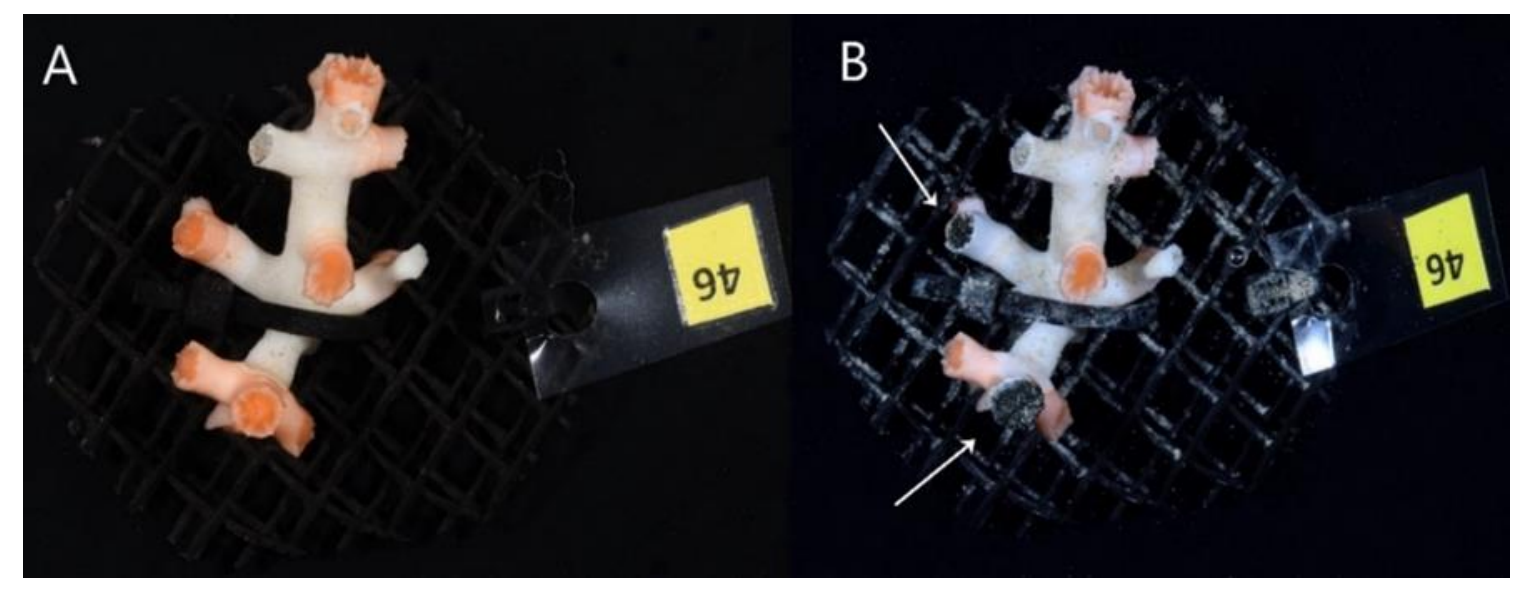

Figure 4.5. Image of Goniocorella dumosa fragment in the $500 \mathrm{mg}^{-1} \mathrm{SSC}$ treatment at $\mathrm{T}_{0}(\mathrm{~A})$ and at $\mathrm{T}_{4}(\mathrm{~B})$. White arrows indicate dead polyps with adjacent coenosarc loss (B).

\subsubsection{Respiration rates}

The effect of treatment and time combined on coral respiration rates was not significant $\left(\mathrm{F}_{(15,18)}\right.$ $=0.58, \mathrm{p}=0.84)$. Control treatment respiration rates were generally similar throughout the experiment, except at $\mathrm{T}_{3}$ when they were slightly higher (Figure 4.6). Respiration rates of 100 and $500 \mathrm{mg} \mathrm{l}^{-1} \mathrm{SSC}$ treatment corals were elevated at $\mathrm{T}_{1}$, when they were $65 \%$ higher than corals from the control and $50 \mathrm{mg} \mathrm{l}^{-1}$ treatments. However, this difference was not statistically significant. Respiration rates in the 100 and $500 \mathrm{mg} \mathrm{l}^{-1}$ treatment corals decreased slightly over time. At $T_{2}$, control respiration rates were similar to those of $T_{1}$, while 100 and $500 \mathrm{mg}^{-1}$ respiration rates were 10 and $3 \%$ higher than control, respectively, compared to the $65 \%$ difference at $\mathrm{T}_{1}$. At $\mathrm{T}_{3}$, respiration rates in the 50, 100 and $500 \mathrm{mg} \mathrm{l}^{-1}$ treatment were 32, 23 and $29 \%$ lower than control respiration rates, respectively. 


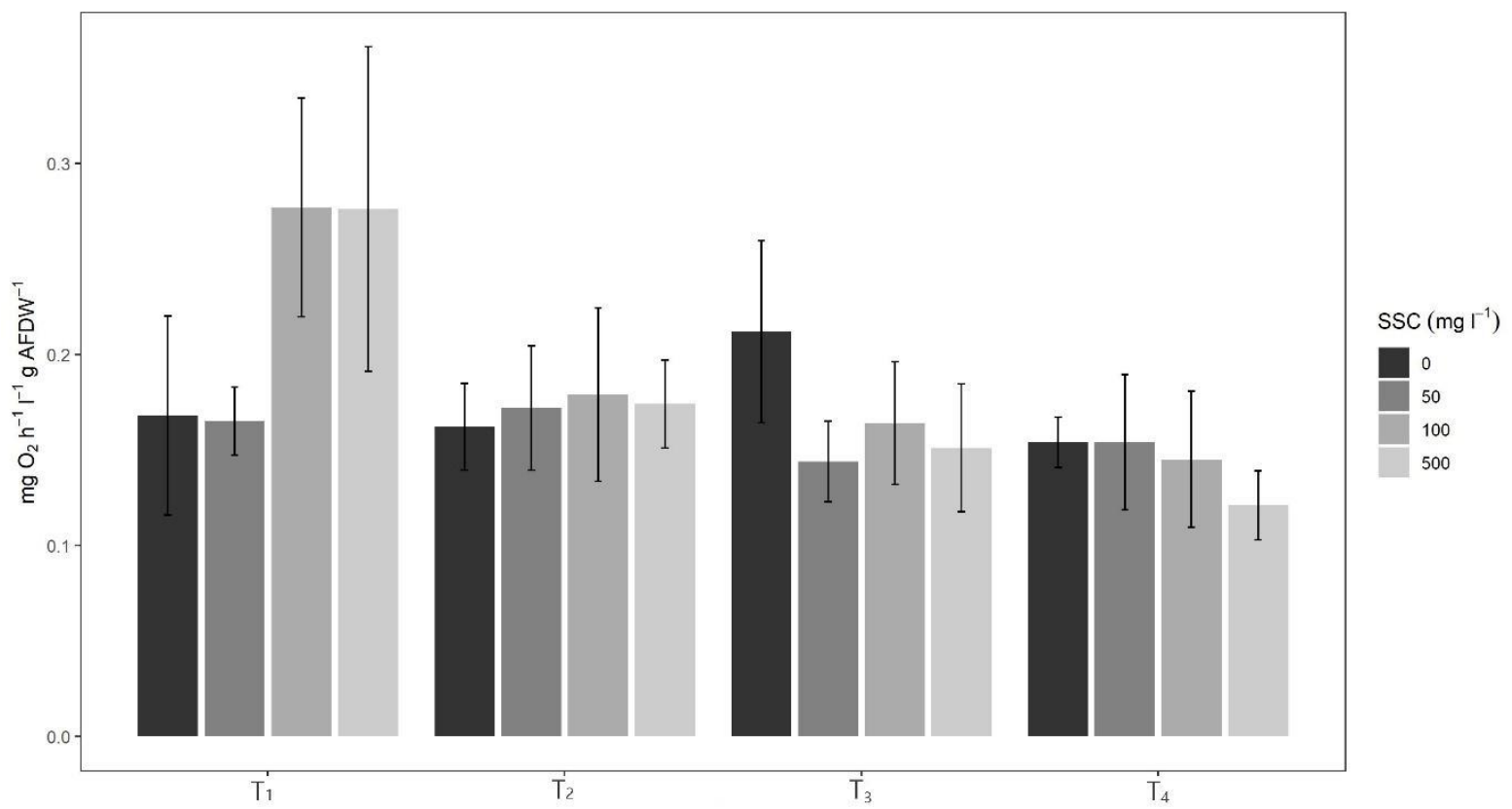

Figure 4.6. Respiration rates of G. dumosa in each of the suspended sediment concentration (SSC) treatments at each sampling time point $\left(\mathrm{T}_{1}=4, \mathrm{~T}_{2}=13, \mathrm{~T}_{3}=22, \mathrm{~T}_{4}=27\right.$ days $)$. Bars show mean values (SE). $\mathrm{N}=4$.

\subsection{Discussion}

Using a controlled laboratory experiment, I investigated the survival and physiological responses of the deep-sea scleractinian coral $G$. dumosa exposed to pulses of elevated suspended sediment concentrations and the short-term recovery potential of this species. Although $100 \%$ of the coral fragments survived, thereby showing some resilience to elevated suspended sediment concentrations over the time period of the experiment, negative effects were observed from $\mathrm{T}_{2}$ (day 13). These included a partial loss of coenosarc tissue and polyp mortality, with these effects being stronger over time in the highest SSCs. Respiration rates were not significantly affected, however respiration rates in the 100 and $500 \mathrm{mg} \mathrm{l}^{-1} \mathrm{SSC}$ were higher than control ones at $\mathrm{T}_{1}$.

While my findings show that G. dumosa can cope with short exposures to elevated SSCs (4 days), it appears that any repeated or prolonged exposure compromises its overall health, as shown by the partial polyp and tissue mortality. These results are important to inform how impacts from human activities that re-suspend seafloor sediment to concentrations up to 500 $\mathrm{mg}^{-1}$ (i.e., bottom-contact fishing activities and potential deep-sea mining) can be managed. 


\subsubsection{Polyp mortality and coenosarc loss}

All G. dumosa fragments survived in the experiment, in contrast to the high mortality rates that occurred in the deep-sea coral L. pertusa after a 14-day continual exposure to elevated SSCs (> 10\% mortality at $54 \mathrm{mg} \mathrm{l}^{-1}$ to $>90 \%$ mortality at $362 \mathrm{mg} \mathrm{l}^{-1} \mathrm{SSC}$; Brooke et al., 2009). Mortality of whole coral fragments also occurred in the shallow water stony species Montipora aequituberculata (11\% and $67 \%$ mortality at 30 and $100 \mathrm{mg}^{-1}$, respectively) and branching stony coral Acropora millepora (11\% mortality at $100 \mathrm{mg} \mathrm{l}^{-1}$ ), however after a much longer exposure period to SSCs (12 weeks; Flores et al., 2012). Flores et al. (2012) suggested that the different mortality rates in corals exposed to the same stress conditions depends on the coral morphology that affects their ability to remove sediment particles deposited on their surfaces.

Although whole fragment mortality did not occur during the length of my experiment, I observed mortality of single polyps in nine treatment coral fragments from $T_{2}$ to $T_{4}$. Polyp mortality rates were low, but they increased over time and were greater in higher SSCs. Low polyp mortality rates of $0.5 \%$ and $3.7 \%$ were also observed in L. pertusa after 3 weeks of repeated exposure to sediment concentrations of 65 and $195 \mathrm{mg} \mathrm{cm}^{-2} \mathrm{day}^{-1}$, respectively (Larsson and Purser, 2011). As G. dumosa calyces containing dead polyps were filled with sediment (Figure 4.6; 4.7), I propose that polyp mortality was caused by sediment accumulation which resulted in smothering of the polyps, as also described by Larsson and Purser (2011).

Along with the dead polyps, partial loss of coenosarc tissue covering the skeleton was also observed (Figure 4.6). Tissue loss has been observed in other studies in corals exposed to suspended (Flores et al., 2012) and settled sediments (Larsson and Purser, 2011). Flores et al. (2012) observed that the \% of tissue loss in the shallow-water coral M. aequituberculata after 4 weeks of exposure to 30 and $100 \mathrm{mg}^{-1}$ SSC was proportional to the percentage of the coral surface covered in sediment. Larsson and Purser (2011) observed coenosarc loss in $42 \%$ of $L$. pertusa fragments buried by 6.5 and $19 \mathrm{~mm}$ layers of sediment.

Similar to observations for L. pertusa (Larsson and Purser, 2011; Larsson et al., 2013), the initial accumulation of sediment particles on G. dumosa occurred on skeletal parts lacking coensarc. After the second and third sediment pulse cycles, sediment deposition was observed adjacent to the portion of the coral fragments covered by coenosarc and, sometimes, in areas where coenosarc tissue had regressed. Sediment deposition on coral tissue has been found to be a cause of tissue mortality (Rogers, 1990; Weber et al., 2006; Flores et al., 2012) hence I 
propose that coenosarc loss in G. dumosa was due to sediment accumulation that could not be removed by G. dumosa.

Warm-water corals can remove sediment particles through active mechanisms such as mucus production and ciliar movements (Bak and Elgershuizen, 1976; Rogers, 1990; Stafford-Smith, 1992; Stafford-Smith and Ormond, 1993; Wild et al., 2004; Wild et al., 2008). I observed mucus production in G. dumosa during the experiment, however, I did not quantify it. Although there is little known about the role of mucus secreted by cold-water corals, it is believed that its function, as for the warm-water corals, is to enhance shedding of particles from their surface tissue (Wild et al., 2008, Zetsche et al., 2016). Mucus secretion has been observed in the deepsea coral L. pertusa as a sediment clearing mechanism (Allers et al., 2013; Larsson et al., 2013; Zetsche et al., 2016). Mucus production can be energetically expensive for corals (Riegl and Branch, 1995). The sediment rejection ability in some tropical corals has been found to decrease with repeated exposures due to exhaustion of mucus secretion cells in the corals (Schuhmacher, 1977). In contrast, repeated exposure of the deep-sea coral L. pertusa to sediment loads (33 $\mathrm{mg} \mathrm{cm}^{-2}$ every second day for 45 consecutive days) did not lead to exhaustion of clearing mechanisms, suggesting that sediment rejection mechanisms in this species are reasonably efficient (Larsson and Purser, 2011).

\subsubsection{Respiration rates}

Respiration rates in G. dumosa were comparable to those reported in L. pertusa (Larsson et al., 2013). G. dumosa respiration rates were not affected by suspended sediment concentration treatments and exposure time, although respiration rates were higher in the 100 and $500 \mathrm{mg} \mathrm{l}^{-1}$ SSC treatment corals compared to controls on the first sampling date (i.e., immediately following exposure to SSC for the initial 4 days of the experiment).

There have only been two studies where respiration rates have been investigated in deep-sea corals exposed to SSC. Respiration rates in L. pertusa fragments exposed to 5 and $25 \mathrm{mg} \mathrm{l}^{-1}$ SSC were not affected by the sediment treatments, with metabolic rates similar between treatment and control corals after 4 and 12 weeks of exposure (Larsson et al., 2013). In contrast, respiration rates in an alcyonacean deep-sea gorgonian coral Primnoa resedaeformis increased after 40 days of exposure to $10 \mathrm{mg} \mathrm{l}^{-1} \mathrm{SSC}$, but not before (Scanes et al., 2018). This was likely because of the chronic effects of low concentrations of sediment (Scanes et al., 2018). As the SSCs were much lower in these earlier experiments than the concentrations used in my 
experiment, and as the exposure periods were much longer, it is not possible to make direct comparisons between the three studies.

There is information on how respiration rates are affected in shallow-water corals in response to sediments, with several studies reporting increased respiration rates (Table 4.3). In the tropical stony corals Acropora palmata, Diploria strigosa and Montastraea anularis, oxygen consumption increased after exposure to settled sediments $(600 \mathrm{mg}$ for $\sim 2 \mathrm{~h}$; Abdel-Sandam and Porter, 1988). M. anularis metabolism increased when exposed to elevated SSC for $90 \mathrm{~min}$ (up to $525 \mathrm{mg}^{-1}$; Dallmeyer and Smith, 1982). Other studies have shown that respiration rates of the stony coral species Galaxea fascicularis and Goniopora somaliensis increased over 4 weeks of sediment exposure ( $26 \mathrm{mg} \mathrm{cm}^{-2} \mathrm{day}^{-1}$; Junje et al., 2014). The stony corals Dichocoenia stokesii and Meandrina meandrites had increased respiration rates after 3 days of exposure to fine sediments (7 to 30 NTU, Telesnicki et al., 1995). In contrast, Riegl and Branch (1995) found that respiration rates in shallow-water temperate corals (4 scleractinian and 5 alcyonacean) decreased when corals were exposed to sediments (settled, $200 \mathrm{mg} \mathrm{cm}^{-2}$ ). No effects on respiration were detected on colonies of Siderastrea radians following burial up to $48 \mathrm{~h}$ (Lirman and Manzello, 2009).

Table 4.3. Summary of sediment effects on respiration rates of different coral species.

\begin{tabular}{|c|c|c|c|c|}
\hline & Coral species & Sediment treatment & Respiration rates response & Reference \\
\hline \multirow{2}{*}{ 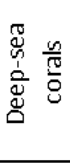 } & Lophelia pertusa & $5,25 \mathrm{mg} \mathrm{l}^{-1}$ for 12 weeks & Respiration rates not affected & Larsson et al., 2013 \\
\hline & Primnoa resedaeformis & $10 \mathrm{mg} \mathrm{l}^{-1}$ for 40 days & $\begin{array}{l}\text { Respiration rates not affected } \\
\text { before } 40 \text { days; respiration rates } \\
\text { increased after } 40 \text { days }\end{array}$ & Scanes et al., 2018 \\
\hline \multirow{16}{*}{$\begin{array}{l}\frac{0}{\pi} \\
\frac{\pi}{0} \\
\frac{0}{0} \\
\frac{\pi}{\pi} \\
3 \\
\vdots \\
\frac{3}{5} \\
\frac{0}{\pi} \\
\frac{\pi}{n}\end{array}$} & Montastraea anularis & $\begin{array}{l}\text { up to } 525 \mathrm{mgl}^{-1} \text { for } 90 \\
\text { minutes }\end{array}$ & Increased respiration rates & Dallmer \& Smith, 1982 \\
\hline & Acropora palmata & & & \\
\hline & Diploria strigosa & $600 \mathrm{mg}$ for $\sim 120$ minutes & Increased respiration rates & Abdel-Sandam \& Porter, 1988 \\
\hline & Montastraea anularis & & & \\
\hline & Favia favus & & & \\
\hline & Favites pentagona & & & \\
\hline & Platygyra daedalea & & & \\
\hline & Gyrosmilia interrupta & & & \\
\hline & Lobophytum depressum & $200 \mathrm{mg} \mathrm{cm}^{-2}$ & Decreased respiration rates & Riegl and Branch, 1995 \\
\hline & Lobophytum venustum & & & \\
\hline & Sinularia dura & & & \\
\hline & Sinularia leptoclados & & & \\
\hline & Sarcophyton ghucum & & & \\
\hline & $\begin{array}{l}\text { Dichocoenia stokesii } \\
\text { Meandrina meandrites }\end{array}$ & 7 to 30 NTU for 3 days & Increased respiration rates & Telesnicki et al., 1995 \\
\hline & $\begin{array}{l}\text { Galaxea fascic ularis } \\
\text { Goniopora somaliensis }\end{array}$ & $\sim 26 \mathrm{mg} \mathrm{cm}^{-1} \mathrm{day}^{-1}$ & Increased respiration rates & Junje et al., 2014 \\
\hline & Siderastrea radians & burial, $48 \mathrm{~h}$ & Respiraiton rates not affected & Lirman \& Manzello, 2009 \\
\hline
\end{tabular}


The increase in coral respiration rates when exposed to sediments has been linked directly to the production of mucus, as it is a high-energetic process (Telesnicki and Goldberg, 1995). Although mucus production was not quantified in this study, it may be possible that the high respiration rates in 100 and $500 \mathrm{mg}^{-1} \mathrm{SSC}$ treatment corals at $\mathrm{T}_{1}$ were due to mucus production, as an increase in metabolic activity would be reflected in increased respiration rates (Larsson et al., 2013). However, respiration rates in G. dumosa fragments exposed to the 100 and $500 \mathrm{mg}^{-1} \mathrm{SSC}$ treatments dropped substantially at $\mathrm{T}_{2}$ compared to $\mathrm{T}_{1}$, at the same time of the first signs of polyps and tissue mortality in treatment corals.

Further analysis will be required to assess the validity of this interpretation, including histological investigation of $G$. dumosa polyps under sediment exposure to reveal any tissue damage and change in mucus cells size.

\subsection{Conclusions}

Despite coral survival and metabolic rates not being affected during the length of my experiment, health condition of treatment corals declined progressively over time, with partial tissue loss and polyp mortality affecting corals in the highest SSC treatments in partcular. The progressive deterioration of coral condition after the short 5-days recovery period indicates that G. dumosa might need a long time to recover from sediment stress exposure, with sublethal effects of elevated SSCs being potentially long-lasting. The study findings indicate that $G$. dumosa could tolerate conditions that it might experience under intense seafloor disturbance from human activities for periods up to 4 days, but repeated, or prolonged, heavy disturbance will increasingly affect its health condition. These results are potentially important in the context of the human activities (bottom trawling, possible future seabed mining) interesting the Chatham Rise seafloor, where G. dumosa is abundant. 


\section{References}

Abdel-Salam, H.A., Porter, J. W., Hatcher, B. G. (1988, August). Physiological effects of sediment rejection on photosynthesis and respiration in three Caribbean reef corals. Proceedings of the 6th international Coral Reef Symposium (Vol. 2, pp. 285-292).

Allers, E., Abed, R. M., Wehrmann, L. M., Wang, T., Larsson, A. I., Purser, A., \& de Beer, D. (2013). Resistance of Lophelia pertusa to coverage by sediment and petroleum drill cuttings. Marine Pollution Bulletin, 74, 132-140.

Armstrong, C.W., van den Hove, S. (2008). The formation of policy for protection of coldwater coral off the coast of Norway. Marine Policy, 32, 66-73.

Bak, R.P.M., Elgershuizen, J.H.B. (1976). Patterns of oil-sediment rejection in corals. Marine Biology, 37, 105-113.

Baird, S.J., Tracey D., Mormede, S., Clark, M. (2013). The distribution of protected corals in New Zealand waters. Research report for the Department of Conservation. Available for download from http://www.doc.govt.nz/publications/conservation/marine-and-coastal/ conservationservices-programme/csp-reports/distribution-of-protected-corals/.

Baussant, T., Nilsen, M., Ravagnan, E., Westerlund, S., Ramanand, S. (2018). Effects of suspended drill cuttings on the coral Lophelia pertusa using pulsed and continuous exposure scenarios. Journal of Toxicology and Environmental Health, Part A, 81, 361-382. DOI: $10.1080 / 15287394.2018 .1444375$

Black, J., Wood, R.A., Berthelsen, T., Tilney, R.L. (2013). Monitoring New Zealand's trawl footprint for deepwater fisheries: 1989-90 to 2009-10. Ministry for Primary Industries.

Boschen, R.E., Rowden, A.A., Clark, M.R., Pallentin, A., Gardner, J.P.A. (2016). Seafloor massive sulfide deposits support unique megafaunal assemblages: implications for seabed mining and conservation. Marine Environmental Research, 115, 78-88.

Bradshaw, C., Tjensvoll, I., Sköld, M., Allan, I.J., Magnusson, J., Naes, K., Nilsson, H.C. (2012). Bottom trawling resuspends sediment and releases bioavailable contaminants in a polluted fjord. Environmental Pollution 170, 232-241.

Brooke, S., Holmes, M., Young, C.M. (2009). Effects of sediment on two morphotypes of Lophelia pertusa from the Gulf of Mexico. Marine Ecology Progress Series, 390, 137-144. 
Buhl-Mortensen, \& L. Mortensen, P.B. (2004). Symbiosis in deep-water corals. Symbiosis, 37, $33-61$.

Cairns S.D. (2012). The Marine Fauna of New Zealand: New Zealand Primnoidae (Anthozoa: Alcyonacea). Part 1. Genera Narella, Narelloides, Metanarella, Calyptrophora, and Helicoprimnoa. NIWA Biodiversity Memoir 126, 71 p.

Cairns, S.D. (2007) Deep-water corals: an overview with special reference to diversity and distribution of deep-water scleractinian corals. Bulletin of Marine Science, 81, 311-322.

Cairns, S.D. (1995). The marine fauna of New Zealand: Scleractinia (Cnidaria: Anthozoa). New Zealand Oceanographic Institute Memoir, 103, 1-210

Campbell, J.S., \& Simms, J.M. (2009). Status Report on Coral and Sponge Conservation in Canada. DFO, St. John's, NL, Canada.

Clark, M.R., \& Dunn, M.R. (2012). Spatial management of deep-sea seamount fisheries: balancing sustainable exploitation and habitat conservation. Environmental Conservation, 39, 204-214.

Clark, M., Althaus, F., Schlacher, T., Williams, A., Bowden, D., Rowden, A. (2016). The impacts of deep-sea fisheries on benthic communities: a review. ICES Journal of Marine Science, $73,51-69$.

Clark, M., Bowden, D., Baird, S., Stewart, R. (2010). Effects of fishing on the benthic biodiversity of seamounts of the "Graveyard" complex, northern Chatham Rise. New Zealand Aquatic Environment and Biodiversity Report No. 46. 40 p.

Clark, M.R., Nodder, S., O' Callaghan, J., Browne, R., Daymond, A., de Joux, P., George, S., Hale, R., Hart, A., Jhugroo, K., Leduc, D., Mobilia, V., Price, O., Searson, S., Solomon, C., Stewart, R., Tracey, D. (2019). Resilience of deep-sea benthic communities to the effects of sedimentation (“ROBES"): Voyage report of Survey 2: June 2019. Unpublished NIWA voyage report. 74

p.

https://niwa.co.nz/sites/niwa.co.nz/files/ROBES2 VoyageReport 2November2019NIWA.pdf

Cummings, V.J., Beaumont, J., Mobilia, V., Bell, J.J., Tracey, D., Clark, M.R., Barr, N. (2020). Responses of a common New Zealand coastal sponge to elevated suspended sediments: Indications of resilience. Marine Environmental Research, 155, 104886. 
Dallmeyer, D.G., Porter, J.W., Smith, G.J. (1982). Effects of particulate peat on the behavior and physiology of the Jamaican reef-building coral Montastrea annularis. Marine Biology, 68, 229-233.

Davies, A.J., Last, K.S., Attard, K., Hendrick, V.J. (2009). Maintaining turbidity and current flow in laboratory aquarium studies, a case study using Sabellaria spinulosa. Journal of Experimental Marine Biology and Ecology, 370, 35-40.

Deltares (2014). Modelling investigations on mine tailing plume dispersion on the Chatham Rise. Deltares Final Report 1209110-000-ZKS-0007, 57 pp.

Durrieu de Madron, X., Ferré, B., Le Corre, G., Grenz, C., Conan, P., Pujo-Pay, M., Buscail, R., Bodiot, O. (2005). Trawling-induced resuspension and dispersal of muddy sediments and dissolved elements in the Gulf of Lion (NW Mediterranean). Continental Shelf Research, 25, 2387-2409.

Ellis, J.I., Clark, M.R., Rouse, H.L., Lamarche, G. (2017). Environmental management frameworks for offshore mining: the New Zealand approach. Marine Policy, 84, 178-192.

Ferré, B., De Madron, X.D., Estournel, C., Ulses, C., Le Corre, G. (2008). Impact of natural (waves and currents) and anthropogenic (trawl) resuspension on the export of particulate matter to the open ocean: application to the Gulf of Lion (NW Mediterranean). Continental Shelf Research, 28, 2071-2091.

FAO. (2009). Management of Deep-Sea Fisheries in the High Seas. FAO, Rome, Italy. 73 p.

Flores, F., Hoogenboom, M.O., Smith, L D., Cooper, T.F., Abrego, D., Negri, A.P. (2012). Chronic exposure of corals to fine sediments: lethal and sub-lethal impacts. PloS one, 7, e37795.

Foley, N.S., van Rensburg, T.M., Armstrong, C.W. (2011). The rise and fall of the Irish orange roughy fishery: an economic analysis. Mar Policy, 35, 756-63.

Freiwald, A., Fosså, J.H., Grehan, A., Koslow, J.A., Roberts, J.M. (2004). Cold-water coral reefs: out of sight no longer out of mind. United Nations Environment Programme - World Conservation Monitoring Centre, Cambridge, UK, 2004.

Glover A.G., Smith C.R. (2003). The deep-sea floor ecosystem: current status and prospects of anthropogenic change by the year 2025. Environ Conservation 30, 219-241. 
Gollner, S., Kaiser, S., Menzel, L., Jones, D.O., Brown, A., Mestre, N.C., Van Oevelen, D., Menot, L., Colaço, A., Canals, M., Cuvelier, D. (2017). Resilience of benthic deep-sea fauna to mining activities. Marine Environmental Research, 129, 76-101.

Hall-Spencer, J., Allain, V., Fosså, J.H. (2002). Trawling damage to Northeast Atlantic ancient coral reefs. Proceedings of the Royal Society B: Biological Sciences, 269, 507-511. doi:10.101098/rspb20011910.

Henry, L.A., Navas, J.M., Hennige, S.J., Wicks, L.C., Vad, J., Roberts, J.M. (2013). Coldwater coral reef habitats benefit recreationally valuable sharks. Biological Conservation, 161, $67-70$.

Järnegren, J. \& Kutti, T. (2014). Lophelia pertusa in Norwegian waters. What have we learned since 2008? - NINA Report 1028. 40 pp.

Larsson, A.I., \& Purser, A. (2011). Sedimentation on the cold-water coral Lophelia pertusa: Cleaning efficiency from natural sediments and drill cuttings. Marine Pollution Bulletin, 62, $1159-1168$.

Larsson, A.I., van Oevelen, D., Purser, A., Thomsen, L. (2013). Tolerance to long-term exposure of suspended benthic sediments and drill cuttings in the cold-water coral Lophelia pertusa. Marine Pollution Bulletin. http://dx.doi.org/10.1016/ j.marpolbul. 02.033.

Lepland, A., \& Mortensen, P.B. (2008). Barite and barium in sediments and coral skeletons around the hydrocarbon exploration drilling site in the Træna Deep, Norwegian Sea. Environmental Geology, 56, 119-129. https://doi.org/10.1007/s00254-007-1145-4.

Levin, L.A., Mengerink, K., Gjerde, K.M., Rowden, A.A., Van Dover, C.L., Clark, M.R., Ramirez-Llodra, E., Currie, B., Smith, C.R., Sato, K.N., Gallo, N. (2016). Defining "serious harm" to the marine environment in the context of deep-seabed mining. Marine Policy, 74, $245-259$.

Lirman, D., \& Manzello, D. (2009). Patterns of resistance and resilience of the stress-tolerant coral Siderastrea radians (Pallas) to sub-optimal salinity and sediment burial. Journal of Experimental Marine Biology and Ecology, 369, 72-77.

Mengerink, K.J., Van Dover, C.L., Ardron, J., Baker, M., Escobar-Briones, E., Gjerde, K., Koslow, J.A., Ramirez-Llodra, E., Lara-Lopez, A., Squires, D. and Sutton, T. (2014). A call for deep-ocean stewardship. Science, 344, 696-698. 
Miller, D.C., Muir, C.L., Hauser, O.A. (2002). Detrimental effects of sedimentation on marine benthos: what can be learned from natural processes and rates? Ecological Engineering, 19, 211-232.

National Oceanic and Atmospheric Administration, Coral Reef Conservation Program. (2010). NOAA Strategic Plan for Deep-Sea Corals and Sponge Ecosystems: Research, Management, and International Cooperation. Silver Spring, MD: NOAA Coral Reef Conservation Program. NOAA Technical Memorandum CRCP 11. 67 pp.

NZ EPA. (2015). Decision on Marine Consent Application Chatham Rock Phosphate Limited to Mine Phosphorite Nodules on the Chatham Rise. Available online at: https://cer.org.za/wpcontent/uploads/2016/08/EPA-New-Zealand-Chatham-Rock-Phosphate-Decision.pdf.

Palanques, A., Guillén, J., Puig, P. (2001). Impact of bottom trawling on water turbidity and muddy sediment of an unfished continental shelf. Limnology and Oceanography, 46, 11001110.

Parsons, D., Tuck, I., Jones, E., Baird, S., Bagley, N., Neil, H. (2013). Potential for sediment suspension from trawl activity on the Chatham Rise. NIWA Client Report No. WLG2013-61.

Philipp, E., Fabricius, K. (2003). Photophysiological stress in scleractinian corals in response to short-term sedimentation. Journal of Experimental Marine Biology and Ecology, 287, 5778.

Probert, P., McKnight, D., Grove, S. (1997). Benthic invertebrate bycatch from a deep- water trawl fishery, Chatham Rise, New Zealand. Aquatic Conservation: Marine and Freshwater Ecosystems, 7, 27-40.

R Core Team (2020). R: A language and environment for statistical computing. R Foundation for Statistical Computing, Vienna, Austria. URL https://www.R-project.org/.

Ramirez-Llodra, E., Trannum, H. C., Evenset, A., Levin, L. A., Andersson, M., Finne, T.E., Hilario, A., Flem, B., Christensen, G., Schaanning, M. and Vanreusel, A. (2015). Submarine and deep-sea mine tailing placements: a review of current practices, environmental issues, natural analogs and knowledge gaps in Norway and internationally. Marine Pollution Bulletin, 97, 13-35.

Rice, S.A., Hunter, C.L. (1992). Effects of suspended sediment and burial on scleractinian corals from west central Florida patch reefs. Bulletin of Marine Science, 51, 429-442. 
Riegl, B., \& Branch, G.M. (1995). Effects of sediment on the energy budget of four scleractinian (Bourne 1900) and five alcyonacean (Lamouroux 1816) corals. Journal of Experimental Marine Biology and Ecology, 186, 259-275.

Roberts, S., \& Hirshfield, M. (2004). Deep-sea corals: out of sight, but no longer out of mind. Frontiers in Ecolology and the Environment, 2, 123-130.

Roberts, J.M., Wheeler, A.J., Freiwald, A., Cairns, S. (2009). Cold-water corals. The biology and geology of deep-sea coral habitats. Cambridge University Press, Cambridge.

Roberts, J.M., Wheeler, A.J., Freiwald, A. (2006). Reefs of the deep: the biology and geology of cold-water coral ecosystems. Science, 312, 543-547.

Rogers, C.S. (1990). Responses of coral reefs and reef organisms to sedimentation. Marine Ecology Progress Series, 62, 185-202.

Schoellhamer, D.H. (1996). Anthropogenic sediment resuspension mechanisms in a shallow microtidal estuary. Estuarine and Coastal Shelf Science, 43, 533-548.

Schuhmacher, H. (1977). Ability in fungiid corals to overcome sedimentation. Proceedings of the 3rd International Coral Reef Symposium, 1, 503-509. In: Taylor, D.L. (Ed.), Rosenstiel School of Marine and Atmospheric Science, University of Miami.

Stafford-Smith, M.G. (1993) Sediment-rejection efficiency of 22 species of Australian scleractinian corals. Marine Biology, 115, 229-243.

Stafford-Smith, M.G., \& Ormond, R.F.G. (1992). Sediment-rejection mechanisms of 42 species of Australian scleractinian corals. Marine and Freshwater Research, 43, 683-705.

Telesnicki, G.J., \& Goldberg, W.M. (1995). Effects of turbidiy on the photosynthesis and respiration of two south Florida reef coral species. Bulletin of Marine Science, 57, 527-539.

Tracey, D.M., Rowden, A.A., Mackay, K.A., Compton, T. (2011). Habitat-forming cold-water corals show affinity for seamounts in the New Zealand region. Marine Ecology Progress Series, $430,1-22$.

Tracey, D., Anderson, O., Naylor, J. (2007). A guide to common deepsea invertebrates in New Zealand waters. New Zealand Aquatic Environment and Biodiversity Report No. 10. 282 p.

Tracey, D., \& Hjorvarsdottir, F. (2019). The state of knowledge of deep-sea corals in the New Zealand region. NIWA Science and Technology Series Number 84. 140 p. 
Weber, M., Lott, C., Fabricius, K.E. (2006). Sedimentation stress in a scleractinian coral exposed to terrestrial and marine sediments with contrasting physical, organic and geochemical properties. Journal of Experimental Marine Biology and Ecology, 336, 18-32.

Wild, C., Huettel, M., Klueter, A., Kremb, S.G., Rasheed, M.Y., Jørgensen, B.B. (2004). Coral mucus functions as an energy carrier and particle trap in the reef ecosystem. Nature, 428, 6670 .

Wild, C., Mayr, C., Wehrmann, L., Schöttner, S., Naumann, M., Hoffmann, F., Rapp, H.T. (2008). Organic matter release by cold water corals and its implication for fauna-microbe interaction. Marine Ecology Progress Series, 372, 67-75.

Zetsche, E.M., Baussant, T., Meysman, F.J., van Oevelen, D. (2016). Direct visualization of mucus production by the cold-water coral Lophelia pertusa with digital holographic microscopy. PloS one, 11, e0146766. https://doi.org/10.1371/journal.pone.0146766.

Zetsche, E.M., Baussant, T., Meysman, F.J., van Oevelen, D. (2016). Direct visualization of mucus production by the cold-water coral Lophelia pertusa with digital holographic microscopy. PloS one, 11, e0146766. 


\section{Chapter 5. Histological assessment of Goniocorella dumosa exposed to elevated suspended sediment concentrations}

\section{Abstract}

While studies on the effects of sediments on deep-sea corals have emphasised the physiological effects of sedimentation, assessments of tissue and cellular reactions to sublethal sediment impacts have not received attention. In this chapter I used histology to explore whether $G$. dumosa ingests sediment particles and whether exposure to high suspended sediment concentrations causes structural damage to this species. I exposed G. dumosa to the same SSCs used in chapter 4, but continuously for four weeks. Histological sections of the polyps did not reveal the presence of sediment particles internally, indicating that $G$. dumosa does not ingest sediment particles actively or incidentally. This suggests that this species might cease feeding when exposed to sediment. Furthermore, no tissue or cellular damage were identified in the sections of the polyps sampled, suggesting that detrimental effects like necrosis might be sudden processes rather gradual ones.

\subsection{Introduction}

Increased sediment levels in the water column and varying levels of sediment deposition rates are known to have detrimental effects on various benthic organisms including corals, however, the sensitivity of coral species to sediments is highly variable (Fabricius, 2005; Erftmeijer et al., 2012). While the effects of increased sedimentation on shallow-water corals have been the subject of various studies since the 1940s, it has been only in the last decade or so that researchers have begun to investigate how deep-sea corals may be affected by elevated sediment concentrations (see Brooke et al, 2009; Larsson and Purser, 2011; Allers et al., 2013; Larsson et al., 2013).

Recent studies have addressed the effects of elevated sediment levels on the deep-sea stony coral Lophelia pertusa, a widespread deep-sea reef-building coral species (e.g., Brooke et al. 2009; Allers et al. 2013; Larsson et al. 2013). This research reported that, while elevated mortality occurred under extremely high suspended sediment loads $\left(\sim 360 \mathrm{mg} \mathrm{l}^{-1}\right)$ or prolonged burial periods (Brooke et al., 2009), L. pertusa shows resilience to lower sedimentation loads, even for long-term exposure (Larsson et al., 2013). 
Shallow-water corals are well-known to use a series of active mechanisms to shed sediments, such as mucus secretion and cilia movements (Abdel-Salam et al., 1988; Stafford-Smith \& Ormond, 1992; Stafford-Smith, 1993). While these mechanisms have been widely investigated in shallow-water corals, they remain unknown in deep-sea corals. Recently, two studies found that L. pertusa uses similar sediment removal mechanisms as shallow-water corals, using cilia movements and producing mucus (Zetsche et al., 2016a; 2016b). Cilia movements require little energy use, potentially explaining the ability of this species to efficiently cope with sediment at low SSCs (Allers et al., 2013; Larsson and Purser, 2011; Larsson et al., 2013).

When some shallow-water corals are exposed to prolonged sediment stress, there is evidence that mucus production is reduced or exhausted as energy resources are used up (Edmunds \& Davies, 1989; Crossland, 1987; Brown \& Bythell, 2005). While most coral species cease activity when exposed to heavy sediment loads (Erftemejier et al., 2012), some shallow-water coral species experiencing turbid conditions have been found to ingest sediment particles from which they derive some nutritional value (Rosenfield et al., 1999; Anthony et al., 2007), or build up higher energy reserves than corals in non-turbid environments (Anthony 2006).

In deep-sea corals, the exhaustion of mucus production or reductions in sediment clearing efficiency has not been observed under various experimental conditions carried out to date (Larsson and Purser, 2911; Larsson et al., 2013). While Larsson et al. (2013) suggested that deep-sea corals might gain nutritional benefit from the organic matter associated with sediment particles, particle ingestion by deep-sea corals has not yet been demonstrated.

While studies on the effects of sediments on deep-sea corals have emphasised the physiological impacts of sedimentation, assessments of tissue and cellular reactions to sublethal sediment impacts has received limited attention. Histological assessments of shallow-water corals exposed to sediments have shown evidence of epithelia attenuation, atrophy and damage to the mucus cells, accumulation of cellular debris and, eventually, loss of tissue integrity and necrosis (Peter \& Pilson, 1985; Riegl \& Bloomer, 1995; Vargas-Ángel et al., 2006). The reduction in the number of mucus cells has been observed in the species Flavia fatus, Favites pentagona, Platygyra daedalea, Gyrosmilia interrupta (Riegl \& Bloomer, 1995), Montastraea cavernosa (Vargas-Ángel 2006; 2007), Astrangia danae (Peter \& Pilson, 1985), and Acropora cervicornis (Hodel \& Vargas-Ángel, 2007). Other reported cellular damage includes swelling of the mucus cells (Vargas-Ángel et al., 2006), atrophy of the mucus cells (Vargas-Ángel et al., 2006; Hodel \& Vargas-Ángel, 2007), a reduction in the number of spirocysts, and an 
increase in the number of granular cells in the tentacles (Vargas-Ángel et al., 2007). However, no histological techniques have been applied to assess sediment-exposed deep-sea corals.

In the fourth chapter of my thesis, I described how the New Zealand deep-sea stony coral Goniocorella dumosa was exposed to repeated sediment pulses (four-day pulses) of suspended sediment concentrations (SSCs) up to $500 \mathrm{mg} \mathrm{l}^{-1}$. No mortality occurred and respiration rates in the high sediment treatment corals were elevated after one sediment pulse, but were similar to the controls after the second and third sediment pulses, indicating that G. dumosa metabolism was not affected (see Chapter 4).

In order to understand how G. dumosa interacts with sediments and the potential structural damage caused by elevated SSCs, the aims of this chapter were to investigate whether Goniocorella dumosa ingests sediment particles during elevated SSCs exposure and, if so, how these particles are processed, and to assess if tissue and cellular damage of polyp sections occurred at different time points during sediment exposure, which might be linked with the negative effects observed in Chapter 4 (necrosis, polyp mortality).

\subsection{Materials and methods}

\subsubsection{Sediment treatments}

G. dumosa samples were collected in June 2020 following the methods described in Chapter 4 (Section 4.2.1).

Coral fragments were exposed to the same SSCs used in Chapter $4\left(0,50,100,500 \mathrm{mg} \mathrm{l}^{-1}\right)$, but continuously for 28 days, aiming at stressing the corals enough to cause the detrimental effects observed in Chapter 4, and to identify these detrimental effects at a microscopic scale. The sediment was prepared as described in Chapter 3 and $4 . \mathrm{N}=4$ replicate experimental chambers were used for each treatment (total $\mathrm{N}=16$ chambers). One coral fragment per chamber $(\mathrm{N}=16)$ was sampled after 5 and then 28 days of sediment exposure. The experimental chambers where the corals were exposed to the target SSCs were the same as those described in Chapters 3 and 4 of this thesis. 


\subsubsection{Histological preparation}

Coral fragments were fixed in $10 \%$ neutral buffered formalin for 48 hours. The fragments were then transferred into $70 \%$ ethanol $(\mathrm{EtOH})$ until decalcification took place. Two polyps were sampled from each coral fragment for decalcification and subsequent histological processing. Polyps were decalcified in $5 \%$ hydrochloric acid $(\mathrm{HCl})$ for 2 hours or until the skeleton was dissolved, rinsed in distilled water to remove any residual acid, and then stored in $70 \%$ ETOH until histological preparation.

Samples were then dehydrated through a series of ethanol concentrations $(70,90,100 \times 2$ changes), transferred to a clearing agent (Xylene), and embedded in paraffin wax. Polyps were then embedded in paraffin blocks, sectioned longitudinally (whole polyps) to $6 \mu \mathrm{m}$ using a rotatory microtome (Leica Biosystems RM2235), mounted on glass microscope slides, stained with haematoxylin and eosin $(\mathrm{H} \& \mathrm{E})$, and coverslips placed over the section. Polyp sections were observed and photographed using a compound light microscope (Olympus BX53) and digital images were taken with the microscope digital camera Olympus SC180 at 4x, 10x, 20x and 40x magnification. Digital images of whole polyp sections where examined for the detection of sediment particles, while images of tentacles were examined to detect any tissue or cellular damage with Olympus cellSens digital imaging software.

\subsection{Results}

All coral fragments survived the 28 days of sediment exposure. The examination of polyp sections (Figure 5.1) with the compound microscope did not reveal the presence of sediment particles in treatment corals at any time point (5 and 28 days). No signs of tissue or cellular degradation were observed in the tissues of the treatment corals at both time points (Figure 5.2). Qualitative assessments detected no thinning of the epidermis and no sudden interruption of the epidermis; there were no signs of mesoglea swelling or detachment. The number of mucus cells in the epidermis did not vary across treatments in treatment corals compared to control ones ( 7 - 11 cells $/ 100 \mu \mathrm{m}$ across all treatments) and qualitative assessments did not detect change in mucuos cells size; the number of spirocysts did not vary between treatments ( $25-31$ cells $/ 100 \mu \mathrm{m}$ across all treatments). The coral epidermis showed integrity across all treatments at both time points (Figure 5.2). 
Both the control samples and $500 \mathrm{mg}^{-1}$ treatment corals showed the presence of reproductive material (oocytes, spermatocytes), and larvae, which were similar in the control and treatment corals $\left(0.192 \pm 0.048 \mathrm{~mm}^{2}\right.$ control, $0.2034 \pm 0.008 \mathrm{~mm}^{2}$ in $\left.500 \mathrm{mg} \mathrm{l}^{-1}\right)$ (Figure 5.3). 


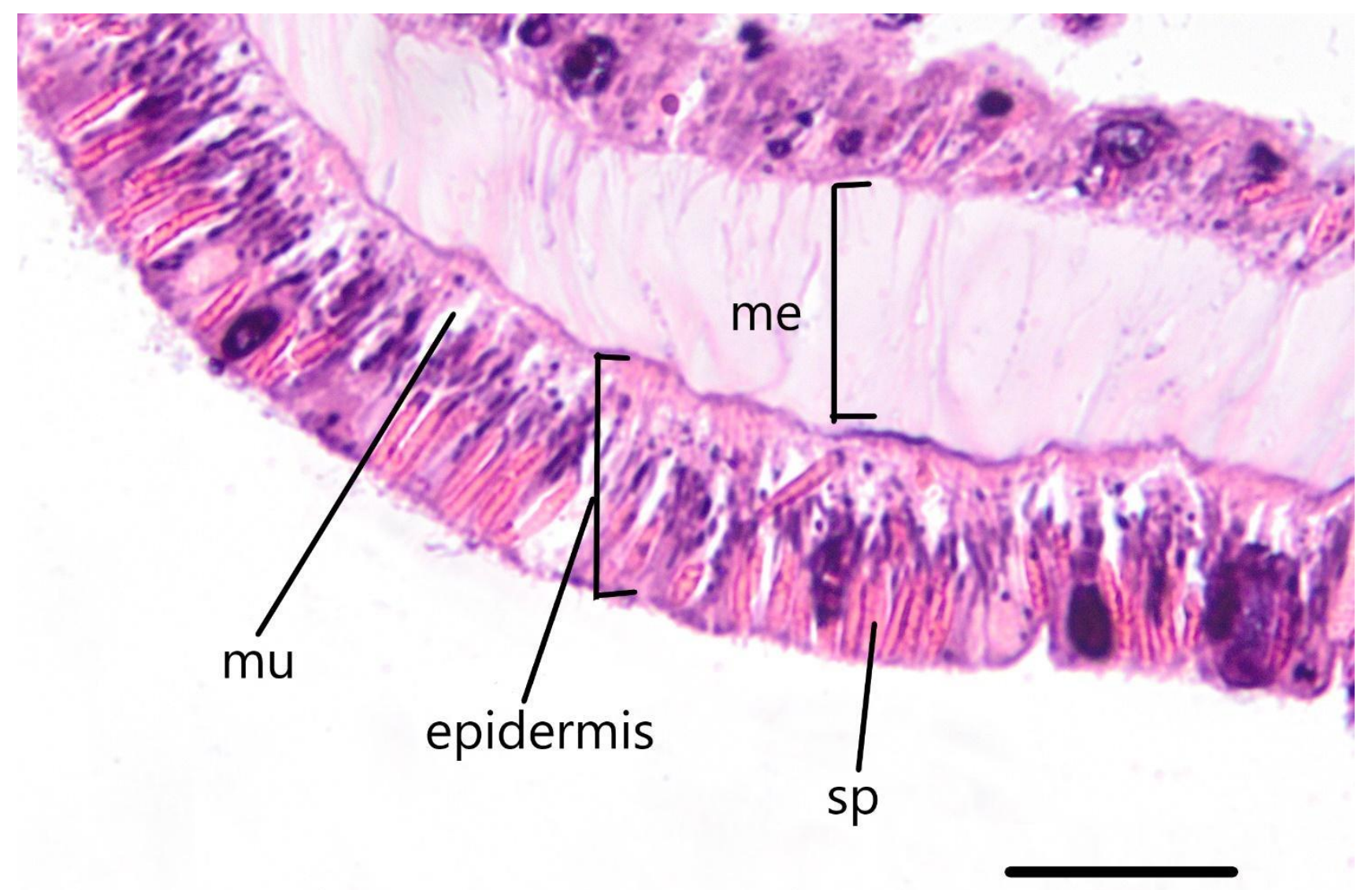

Figure 5.1. Histological section of a portion of Goniocorella dumosa tentacle showing: epidermis, mesoglea (me), mucocyte cells (mu) and spirocyst cells (sp). Scale bar $=50 \mu \mathrm{m}$. 

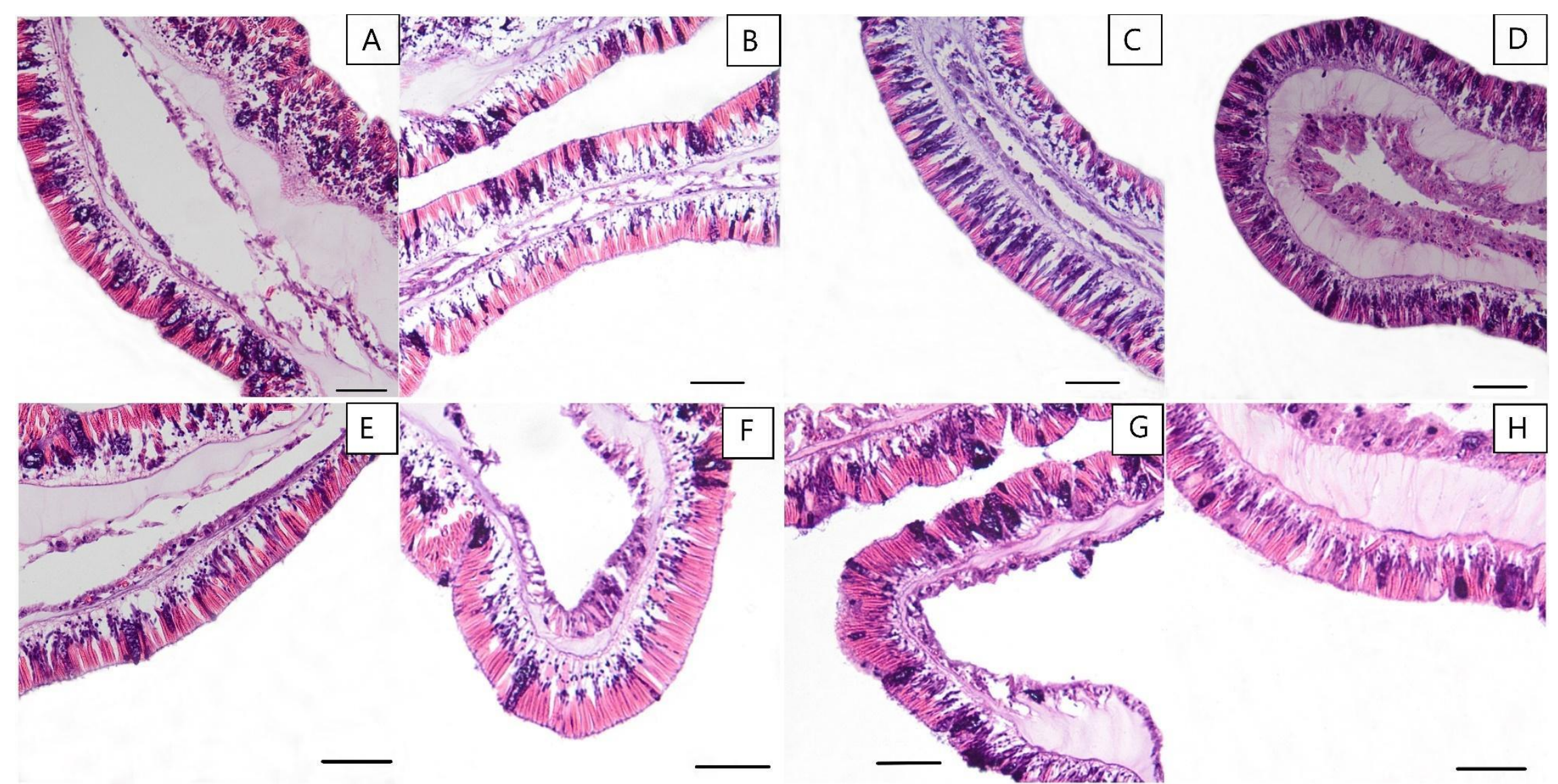

Figure 5.2. Histological sections of Goniocorella dumosa tentacles epidermis after 5 (A-D) and 28 (E-H) days of sediment exposure, showing integrity of cells and tissue structure. Sections of all treatment corals are shown: control (A, E), $50 \mathrm{mg} \mathrm{l}^{-1}(\mathrm{~B}, \mathrm{~F}), 100 \mathrm{mg} \mathrm{l^{-1 }}(\mathrm{C}, \mathrm{G})$ and $500 \mathrm{mg} \mathrm{l}^{-1}$ $(D, H)$. Scale bars $=50 \mu \mathrm{m}$. 


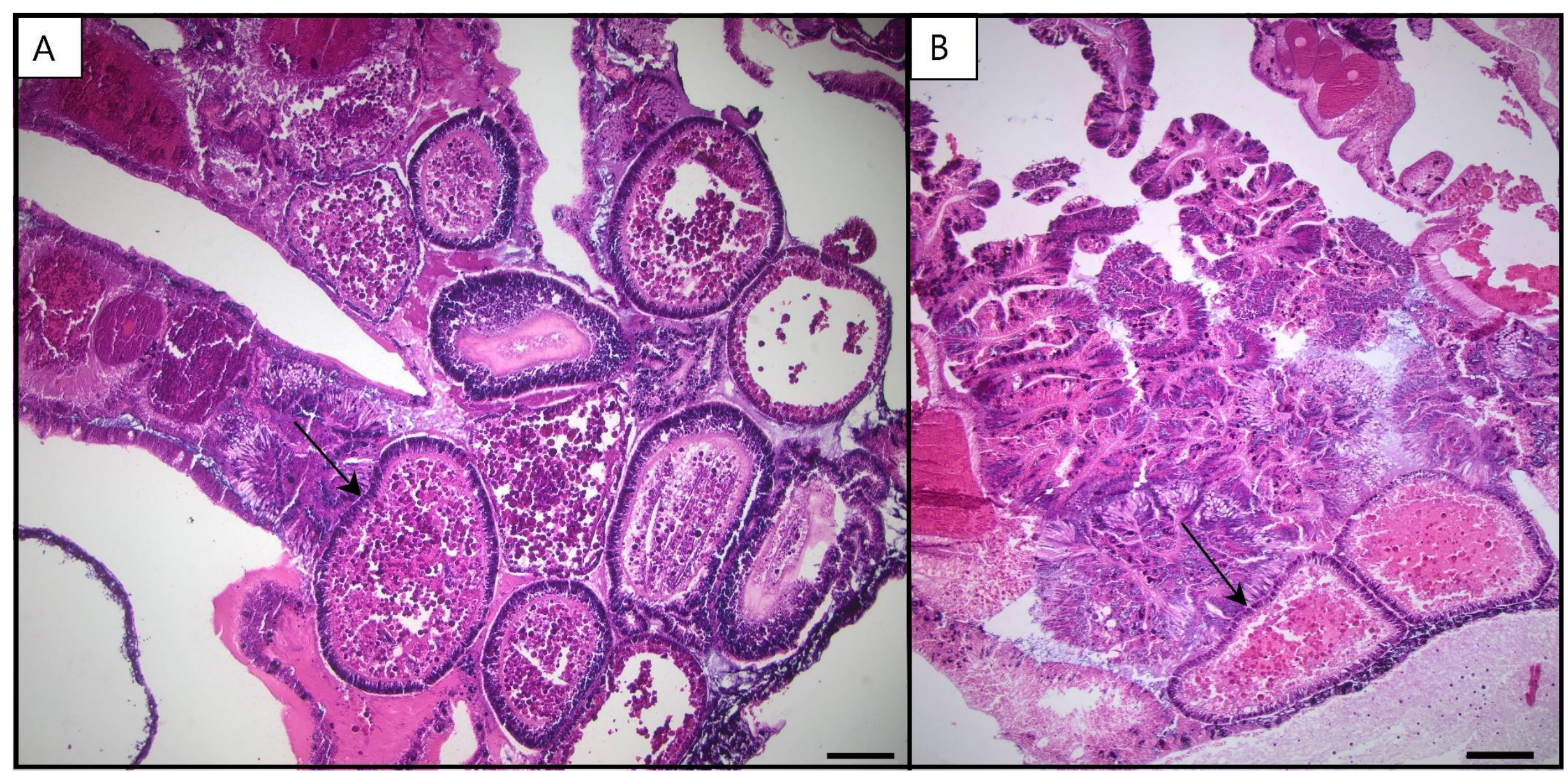

Figure 5.3. Longitudinal sections of a Goniocorella dumosa polyp showing the presence of larvae in control (A) and $500 \mathrm{mg} \mathrm{l}^{-1}$ treatment coral (B) polyps. Larvae are indicated by arrows; sections are stained with haematoxylin and eosin. Scale bars $=200 \mu \mathrm{m}$. 


\subsection{Discussion}

\subsubsection{The lack of sediment particles: implications}

The absence of any extraneous particles in treatment corals suggests that $G$. dumosa does not ingest sediment, either accidentally or to gain nutritional advantage from the organic matter that might be associated with the particles. Larsson et al. (2013) hypothesised that deep-sea corals might benefit from the organic matter associated with sediment particles as they live heterotrophically. To date, the ingestion of sediment particles by deep-sea corals has not been investigated, although it is important to note that the number of studies on deep-sea corals is very limited. In contrast, there is evidence that some shallow-water coral species ingest sediment particles accidentally or actively to benefit from moderate concentrations of suspended and settled sediments for feeding. For example, the coral species Fungia horrida, Pocillopora damicornis and Acropora millepra ingest sediment particles to benefit from the organic matter associated with them (Rosenfield et al., 1999; Anthony \& Fabricius, 2000), while other species can accidentally ingest sediment particles that will be regurgitated hours later as a mucus-bound pseudofaeces (Logan 1988). Stafford-Smith \& Ormod (1992) found that of the 42 species of shallow-water corals species investigated, many ingested sediment particles, and all the 42 species ingested food-coated sediment particles. A possible reason why G. dumosa did not ingest sediment particles in this study is that the sediment concentrations were high compared to those of other studies, as the shallow-water species observed to ingest sediment particles were exposed to lower SSCs $\left(<30 \mathrm{mg} \mathrm{l}^{-1}\right)$.

The absence of sediment particles inside the coral polyp could also demonstrate that $G$. dumosa, when exposed to suspended sediments, ceases feeding for the duration of the exposure. This hypothesis is supported by observations from Chapter 4, when polyps of coral fragments in the $50 \mathrm{mg}^{-1} \mathrm{SSC}$ treatment were retracted during the sediment exposure period (100 and $500 \mathrm{mg}^{-1}$ SSC treatment corals were not visible due to the elevated water turbidity). Starving conditions could potentially affect the energetic resources of this species, particularly under chronic sediment exposure.

Understanding of the consequences of high sediment levels on deep-sea coral energetics is very limited, and the results so far are conflicting. In a series of experiments on the deep-sea species L. pertusa, six-months starved coral fragments were as efficient as fed coral fragments in shedding sediment particles (Larsson \& Purser, 2011). Additionally, a 12-week exposure 
period to SSCs did not affect respiration rates or fatty acid composition and abundance (Larsson \& Purser, 2011). Growth rates however in coral fragments exposed to $25 \mathrm{mg}^{-1} \mathrm{SSCs}$ were significantly lower than those exposed to $5 \mathrm{mg}^{-1}$ SSCs (Larsson et al., 2013).

\subsubsection{Lack of structural damage}

I did not identify tissue or cellular damage in the treatment corals examined histologically, although, in a previous experiment (Chapter 4) I observed partial coenosarc loss and partial polyp mortality in treatment corals at all sediment concentrations after two and three cycles of sediment exposure. It may be possible that the observed effects described in Chapter 4 (i.e. coenosarc loss and eventually, polyp mortality) are sudden processes rather than gradual ones, and that the micro effects that can lead to cellular necrosis are also manifested suddenly.

Sediment-induced structural damage observed in shallow-water stony corals are summarized in Table 5.1. Tissue damage documented in response to sediment exposure in shallow-water corals included thinning of the epidermis layer (Riegl \& Bloomer, 1995; Vargas-Ángel et al., 2007; Hodes \& Vargas-Ángel, 2007) and granular mesoglea (Vargas-Ángel et al., 2006). Sediment stress has also been reported to cause abnormal-looking zooxanthellae and loss of zooxanthellae in some shallow-water coral species (Vargas-Ángel et al., 2007), although this might be an effect of light reduction due to increased turbidity rather than sediment directly (Rogers, 1979).

In shallow-water corals, sustained high levels of sedimentation have been shown to exhaust some coral species abilities to produce mucus, as mucus production stops and the mucus secretory cells are lost (Peter \& Pilson, 1985; Brown \& Bythell 2005). The reduction of the number of fully functioning mucus cells has been the most common effect observed in shallowwater corals exposed to sediment stress (Table 5.1). 
Table 5.1. Summary of literature describing tissue and cellular damage induced by sediments in shallow-water corals.

\begin{tabular}{|c|c|c|}
\hline Response observed & Coral species (Scleractinia) & Reference \\
\hline $\begin{array}{l}\text { Decrease in the number of mucus cells } \\
\text { in the ectoderm }\end{array}$ & $\begin{array}{l}\text { Favia favus; } \\
\text { Favites pentagona; } \\
\text { Platygyra daedalea; } \\
\text { Gyrosimilia interrupta; } \\
\text { Astrangia danae; } \\
\text { Montastraea cavernosa; } \\
\text { Acropora cervicornis }\end{array}$ & $\begin{array}{l}\text { Riegl and Bloomer, 1995; } \\
\text { Peter and Pilson, 1985; } \\
\text { Vargas-angel et al., 2006; } \\
\text { Vargas-Angel et al., 2007; } \\
\text { Hodel et al., } 2007\end{array}$ \\
\hline Thinning of the epidermal layer & $\begin{array}{l}\text { Favia fatus; } \\
\text { Favites pentagona; } \\
\text { Platygyra daedalea; } \\
\text { Gyrosmilia interrupta; } \\
\text { Montastraea cavernosa; } \\
\text { acropora cervicornis }\end{array}$ & $\begin{array}{l}\text { Riegl and Bloomer, 1995; } \\
\text { Vargas-Angel et al., 2007; } \\
\text { Hodel et al., } 2007\end{array}$ \\
\hline Atrophy of mucus cells & $\begin{array}{l}\text { Acropora cervicornis; } \\
\text { Montastraea cavernosa }\end{array}$ & $\begin{array}{l}\text { Hodel et al., 2007; } \\
\text { Vargas-angel et al., } 2006\end{array}$ \\
\hline Swelling of mucus cells & Montastraea cavernosa & Vargas-Angel et al., 2006 \\
\hline $\begin{array}{l}\text { Reduction in the abundance of } \\
\text { spyrocysts }\end{array}$ & Montastraea cavernosa & Vargas-Angel et al., 2007 \\
\hline $\begin{array}{l}\text { Increased abundance of granular cells } \\
\text { in the tentacles }\end{array}$ & Montastraea cavernosa & Vargas-Angel et al., 2007 \\
\hline
\end{tabular}

\subsection{Conclusions}

The absence of structural cellular damage in G. dumosa fragments after four weeks of high SSCs exposure indicates some short-term tolerance of this species to high SSCs, although partial coenosarc loss and tissue mortality were observed in the previous chapter.

The lack of ingested sediment indicates that $G$. dumosa is likely efficient at shedding sediment particles from the polyp surface region and suggest that $G$. dumosa might cease feeding during sediment exposure, however, the latter is a personal hypothesis and further investigations will be needed to confirm it. Reduced feeding could have important negative impacts on the energy 
balance of this species, particularly if the sediment stress exposure from anthropogenic impacts is long-lasting.

Additional research is required to thoroughly investigate how the exposure of sediment can impact the energetic resources of $G$. dumosa, and indirectly, how growth and reproduction processes can be affected. 


\section{References}

Abdel-Salam, H.A., Porter, J.W., Hatcher, B.G. (1988). Physiological effects of sediment rejection on photosynthesis and respiration in three Caribbean reef corals. Proceedings of the 6th International Coral Reef Symposium, 2, 285-292.

Allers, E., Abed, R.M., Wehrmann, L.M., Wang, T., Larsson, A I., Purser, A., de Beer, D. (2013). Resistance of Lophelia pertusa to coverage by sediment and petroleum drill cuttings. Marine Pollution Bulletin, 74, 132-140.

Anthony, K.R. (2006). Enhanced energy status of corals on coastal, high-turbidity reefs. Marine Ecology Progress Series, 319, 111-116.

Anthony, K.R., \& Fabricius, K.E. (2000). Shifting roles of heterotrophy and autotrophy in coral energetics under varying turbidity. Journal of Experimental Marine Biology and Ecology, 252, $221-253$.

Anthony, K.R., Connolly, S.R., Hoegh-Guldberg, O. (2007). Bleaching, energetics, and coral mortality risk: Effects of temperature, light, and sediment regime. Limnology and Oceanography, 52, 716-726.

Brooke, S.D., Holmes, M.W., Young, C.M. (2009). Sediment tolerance of two different morphotypes of the deep-sea coral Lophelia pertusa from the Gulf of Mexico. Marine Ecology Progress Series, 390, 137-144.

Brown, B., \& Bythell, J. (2005). Perspectives on mucus secretion in reef corals. Marine Ecology Progress Series, 296, 291-309. doi: 10.3354/meps296291.

Crossland, C.J. (1987). In situ release of mucus and DOC-lipid from the coral Acropora variabilis and Stylophora pistillata. Coral Reefs 6, 35-42.

Edmunds, P., \& Davies, P.S. (1989). An energy budget for Porites porites (Scleractinia), growing in a stressed environment. Coral Reefs, 8, 37-43.

Erftemeijer, P.L., Riegl, B., Hoeksema, B.W., Todd, P.A. (2012). Environmental impacts of dredging and other sediment disturbances on corals: a review. Marine Pollution Bulletin, 64, $1737-1765$.

Etnoyer, P., \& Morgan, L.E. (2004). Occurrences of habitat-forming deep water corals in the Northeast Pacific Ocean. Final Report to NOAA Office of Habitat Protection, Washington DC. 
Fabricius, K.E. (2005). Effects of terrestrial runoff on the ecology of corals and coral reefs: review and synthesis. Marine Pollution Bulletin, 50, 125-146.

Hodel, E., \& Vargas-Ángel, B. (2007). Histopathological assessment and comparison of sedimentation and phosphate stress in the Caribbean staghorn coral, Acropora cervicornis. Microscopy and Microanalysis, 13, 220-221.

Larsson, A.I., \& Purser, A. (2011). Sedimentation on the cold-water coral Lophelia pertusa: cleaning efficiency from natural sediments and drill cuttings. Marine Pollution Bulletin, 62, $1159-1168$.

Larsson, A. I., van Oevelen, D., Purser, A., Thomsen, L. (2013). Tolerance to long-term exposure of suspended benthic sediments and drill cuttings in the cold-water coral Lophelia pertusa. Marine Pollution Bulletin, 70, 176-188.

Logan, A. (1988). Sediment-shifting capability in the recent solitary coral Scolymia cubensis (Milne-Edwards and Haime) from Bermuda. Bulletin of Marine Science, 43, 241-248.

Peters, E.C., \& Pilson, M.E. (1985). A comparative study of the effects of sedimentation on symbiotic and asymbiotic colonies of the coral Astrangiadanae Milne Edwards and Haime 1849. Journal of Experimental Marine Biology and Ecology, 92, 215-230.

Riegl, B., \& Bloomer, J.P. (1995). Tissue Damage in Scleractinian and Alcyonacean Corals Due to Experimental Exposure to Sedimentation. Marine \& Environmental Sciences Faculty $\begin{array}{llll}\text { Proceedings, } & \text { Presentations, } & \text { Speeches, } & \text { Lectures. }\end{array}$ https://nsuworks.nova.edu/occ facpresentations/114

Rogers, C.S. (1979). The effect of shading on coral reef structure and function. Journal of Experimental Marine Biology and Ecology, 41, 269-288.

Rosenfeld, M., Bresler, V., Abelson, A. (1999). Sediment as a possible source of food for corals. Ecology Letters, 2, 345-348.

Stafford-Smith, M.G. (1993). Sediment-rejection efficiency of 22 species of Australian scleractinian corals. Marine Biology, 115, 229-243.

Stafford-Smith, M.G., \& Ormond, R.F.G. (1992). Sediment-rejection mechanisms of 42 species of Australian scleractinian corals. Marine and Freshwater Research, 43, 683-705. 
Vargas-Ángel, B., Peters, E.C., Kramarsky-Winter, E., Gilliam, D.S., Dodge, R.E. (2007). Cellular reactions to sedimentation and temperature stress in the Caribbean coral Montastraea cavernosa. Journal of Invertebrate Pathology, 95, 140-145.

Vargas-Ángel, B., Riegl, B., Gilliam, D.S., Dodge, R.E. (2006). An experimental histopathological rating scale of sedimentation stress in the Caribbean coral Montastraea cavernosa. Proceedings of the 10th International Coral Reef Symposium, 1168-1173.

Zetsche, E. M., Baussant, T., Van Oevelen, D. (2016a). Ciliary removal of particles by the cold-water coral Lophelia pertusa. Reef Encounter, 31, 53-56.

Zetsche, E.M., Baussant, T., Meysman, F.J., van Oevelen, D. (2016b). Direct visualization of mucus production by the cold-water coral Lophelia pertusa with digital holographic microscopy. PloS one, 11, e0146766. 


\section{General discussion and conclusions}

\subsection{Summary of key findings}

Increases in suspended sediment concentrations (SSC) in the water column are a major factor contributing to the degradation of marine ecosystems worldwide. In New Zealand the resuspension of bottom sediments caused by storms (in shallow-waters) and anthropogenic activities, such as bottom fishing activities and potential future deep-sea mining, is considered a major threat to benthic ecosystems. Sponges and corals, being benthic suspension feeders, can be particularly susceptible to elevated SSCs. Sponges and corals are important fauna of New Zealand coastal and deep-sea waters. In this thesis I investigated the responses of New Zealand shallow and deep-sea sponges, and a deep-sea coral to elevated suspended sediment loads. This research was carried out through a series of controlled laboratory experiments that took place at the National Institute of Water and Atmospheric Research's (NIWA) Marine Environmental Manipulation Facility (MEMF).

In Chapter 2, which describes experimental results of subjecting the sponge species Crella incrustans to a gradient of SSCs for four weeks, I did not find a SSC threshold where the functioning of this species was compromised. $C$. incrustans demonstrated resilience to high SSCs. Physiological responses were variable among control and treatment sponges, and sponges exposed to elevated SSCs were not compromised. In Chapter 3, describing experimental results of exposing the deep-sea sponge Ecionemia novaezealandiae to three target SSCs, I found that respiration rates of the sponges exposed to $500 \mathrm{mg} \mathrm{l}^{-1} \mathrm{SSC}$ were significantly affected after just one day of sediment exposure, whereas the difference between control and treatment sponge respiration rates was smaller after two weeks of sediment exposure. At the end of the two-week sediment exposure, treatment sponges in the two highest SSC treatments showed partial necrosis. In Chapter 4, describing experimental results of exposing the deep-sea coral Goniocorella dumosa to repeated suspended sediment pulses over four weeks, I found that these did not affect physiological responses of this species, whereas partial tissue loss and partial polyp mortality increased over time in the treatment corals. In Chapter 5, my histological investigation of $G$. dumosa polyps did not reveal any evidence for sediment ingestion or structural damage at the tissue or cellular level after the corals were exposed to different levels of SSCs for four weeks. 


\subsection{Relationships with sediments}

As benthic sessile organisms, sponges and corals are unable to escape changes in environmental quality. This constraint of sessile life has resulted in the ability of many organisms to acclimate to or to be well-adapted to environmental stressors (Hoegh-Guldberg 1999). For example, about $10 \%$ of studied sponges are adapted to life in a variety of sediment conditions, in particular deep-sea sponges (Schönberg, 2016). Some sponges even gain benefits from actively taking up sediments for body reinforcement and skeletal material (Schönberg, 2016 and references therein). In some sponge species, active sediment incorporation is thought to be a selective process based on sediment size and mineralogy (Cerrano et al., 2004).

Coral sensitivity to sedimentation is extremely variable. Some shallow-water corals are adapted to sediment and can gain benefits from the sediment in some cases, although to a lesser extent than sponges. Some symbiotic shallow-water corals are able to switch their trophic mode from autotrophy to heterotrophy when exposed to increased turbidity, thus maintaining a positive energy balance and broadening their physiological niche (Anthony \& Fabricius, 2000). Some shallow-water coral species can even gain benefits from moderate turbidity, as they actively ingest sediment particles from which they derive some nutritional value (Rosenfield et al., 1999; Anthony et al., 2007).

In this thesis, different 'relationships' with sediments were identified in the three species. In Chapter 2, I found that the shallow-water sponge Crella incrustans incorporated sediment particles following sediment exposure; in Chapter 3, all Ecionemia novaezealandiae samples, including control, had sediment particles embedded in their tissue, internally, indicating that this species takes up sediment in its natural environment; in Chapter 5, I found that G. dumosa polyps did not contain sediment particles internally, suggesting that this species ceased feeding for the duration of experimental sediment exposure.

Sediment particles were likely incorporated passively by $C$. incrustans as a consequence of not being able to cease pumping for a prolonged period. Sediment particles incorporated by $C$. incrustans did not appear to compromise its survival or physiology over the time scale of my experiment. Incorporation of sediment particles by E. novaezealandiae might have been an active process (i.e., sponges might have incorporated sediments to gain benefits). Active incorporation of sediments in sponges can be a strategy to replace the skeleton or to anchor in soft substrate (Cerrano et al., 2007). When needed for anchoring, sand, larger particles and pebbles are incorporated mainly basally by the sponges, which I observed in $E$. 
novaezealandiae (in addition to the sediment particles scattered internally). In general, sponges do not actively incorporate fine particles into their skeletons (Schönberg 2016), and therefore this suggests E. novaezealandiae actively incorporated coarse grained particles (Chapter 3). The absence of sediment particles in G. dumosa indicates that sediment ingestion does not occur for this species either actively or passively.

\subsection{Physiological responses of sediment rejection mechanisms}

\subsubsection{Sediment rejection mechanisms in sponges}

Although some sponges are well adapted or even thrive in environments characterized by high levels of sedimentation, it is recognized that high sediment levels are deleterious to most sponge species (Bell et al., 2015). Different mechanisms have been observed in sponges to avoid detrimental consequences from sediments: temporary arrest or reduction of pumping activity (Tompkins-Macdonald \& Leys, 2008), mucus production (Bannister et al., 2012) and morphology (Bell et al., 2002; Bell 2004). Pumping arrest or reduction and mucus production have been accompanied by physiological responses. Arrest or reduction in pumping activity due to sediment exposure has been linked to a decrease in oxygen consumption rates, whereas mucus secretion to shed sediments has been linked to increased respiration rates (Bannister, 2012; Biggerstaff et al., 2017; McGrath et al., 2017). I propose that the following different mechanisms explain the responses of my study species to high SSCs.

In the shallow-water sponge $C$. incrustans respiration rates were not affected by elevated SSCs for up to four weeks and treatment sponges already showed the presence of sediments internally after seven days of sediment exposure. The presence of sediment particles after different sediment exposure periods (1, 3 and 4 weeks) indicates that $C$. incrustans could not stop pumping for prolonged periods. Pumping arrest or reduction is a defensive mechanism that prevents sediment entering and clogging the aquiferous system. In fact, fine sediment particles can cause clogging of the aquiferous system and prevent feeding, which can lead to an energy deficit at the expense of other processes like growth and reproduction (Roberts et al., 2006; Whalan et al., 2007). In $C$. incrustans, a trade-off between avoiding sediment particles entering the sponge body and the necessity to pump to obtain food and oxygen might have occurred, thus sponges might have pumped although this resulted in the incorporation of sediments. 
In the deep-sea sponge E. novaezealandiae respiration rates were lower in all sediment treatment sponges compared to controls, and all sponges contained sediments internally, including control sponges. The lower respiration rates were hypothesized to be a consequence of reduced pumping rates, and the presence of internal sediment particles, including in control sponges, were not related to the experimental treatments. This observation was consistent with the decreased respiration rates in treatment sponges, compared to controls, during the experiment.

\subsubsection{Sediment rejection mechanisms in G. dumosa}

The effects of high SSC are negative for most corals (Fabricius 2005; Erftemeijer et al., 2012). In corals, the mechanisms adopted to avoid damage from sediments involve sediment shedding via cilia movements and mucus production (Rogers 1990; Stafford-Smith 1993). In scleractinian corals there is no clear correlation between active sediment removal mechanisms and physiological responses: while several coral species have been found to increase their respiration rates when exposed to sediments, others showed no such response (see Table 4.1).

In this study of the deep-sea coral G. dumosa, mucus production was observed but not quantified. Respiration rates in the two high sediment treatments were elevated, compared to controls, after one pulse of sediment exposure, but became similar to controls after the second and third pulses of sediment exposure. As mucus was not quantified, it is unknown if the initial elevated respiration rates in treatment corals were related to the quantity of mucus produced. Furthermore, no sediment particles were observed internally in G. dumosa polyps exposed to high SSCs for 28 days and no change in mucocyte cell dimension or number were detected. The lack of sediment in G. dumosa suggest that polyps were retracted into their calyces for the duration of the sediment exposure, even at lower SSC $\left(50 \mathrm{mg} \mathrm{l}^{-1}\right)$, and therefore that corals might have ceased feeding. Although I did not quantify mucus production in G. dumosa, the respiration rates of treatment corals being similar to those of the controls might indicate that the metabolic cost to G. dumosa for clearing sediments are not high for the duration of my experiment. Recent studies have demonstrated that the cost of mucus production in the deepsea stony coral $L$. pertusa is low, supporting my interpretation that it might be the same for $G$. dumosa. 


\subsection{Research limitations}

During my research, for the first time, the deep-sea E. novaezealandiae and G. dumosa were maintained live in a controlled laboratory environment. While in 2019 experiments on both species were successful, in 2018 an initial experimental trial on E. novaezealandiae failed due to high sponge mortality that occurred during acclimation. The collection and maintenance of both deep-sea species involved a number of limitations. First of all, collection by beam trawling results in stress like tumbling and short-term exposure to air. Laboratory conditions were maintained as optimal as possible by providing a dark environment, constant temperature comparable to that at the collection site and an adequate flow rate; however, other factors could not be controlled, like pressure. The potential stress factors were accounted by stabilising the species in the laboratory before starting the experiments.

Limitations were also faced with respect to the experiments. The initial, preferable, option was to expose the study species to a wide range of SSCs with no replication, as was conducted in the $C$. incrustans experiment, in order to find a sediment threshold above which species health would be compromised. However, the high variability found in $C$. incrustans responses, and the variability found in preliminary trials of E. novaezealandiae and G. dumosa responses, made me opt for a different experimental approach (for E. novaezealandiae and G. dumosa) with few, fixed, SSC treatments in favour of higher replication. The experiment design used for E. novaezealandiae investigations was also constrained by the number of specimens collected. With a limited number of E. novaezealandiae specimens available, I cut the bigger sponges to increase the sample size. As sponge variability between different individuals is large, the use of clones from the same donor sponges reduces this variability, thus the effects of high SSCs were tested on a smaller sponge population than was the total number of the sponges once they were cut. If more sponges had been collected, the effects of high SSCs would have been tested on a larger sponge population. Furthermore, the priority to understand the effects of sediments on E. novaezealandiae, including sectioning the specimens to assess internal necrosis, prevented me from including a recovery period, which could have been useful to understand this species ability to recover once the SSC exposure stress has ceased. 


\subsection{Future directions}

\subsubsection{Sediment impacts on juvenile and larval stages}

In this thesis, the effects of high SSCs on C. incrustans, E. novaezealandiae and G. dumosa were tested on adult specimens. Understanding of the impacts of high SSCs on larval and juvenile stages of sponges and corals is much more limited compared to what is known about their adult stages, but there is some evidence that sedimentation effects may be more deleterious on juvenile and larval stages of both groups (Gilmour, 1999; Maldonado et al., 2008; Wahab et al., 2019). Previous studies suggest that high SSCs caused significant mortality in the larval stages of the deep-sea coral L. pertusa by clogging of the cilia, which prevented larvae from swimming (Larsson et al., 2013; Jänegren et al., 2017). The effects of elevated SSCs on shallow-water coral larvae include reduced larval recruitment, survival and settlement (Gilmour, 1999; Babcock \& Smith, 2000, Birrel et al., 2005, Goh and Lee, 2008). The influence of sediment on sponge larvae is very poorly understood (Bell et al., 2015). Recently, one study reported mortality and reduced swimming speed for larvae of the shallow-water sponge Carteriospongia foliascens in response to sediment (Wahab et al., 2019).

The effects of high SSCs on larval and juvenile stages of my study species deserve investigations, as they might be more deleterious than the effects reported on adults.

\subsubsection{The energetic cost of coping with high suspended sediment concentrations}

In Chapter 2, I found that when $C$. incrustans was exposed to sediments they developed "fistules"; in Chapter 3, I found that E. novaezealandiae reduced its respiration rates, very likely as a response to a reduction in pumping; in Chapter 4 and 5, I found that G. dumosa produced mucus and I propose that it might stop feeding for the entire period of sediment exposure. All these responses may have negative effects on the energetic balance of these species, either as a result of use of other energetic resources due to feeding reduction ( $E$. novaezealandiae and G. dumosa) or due to active mechanisms like "fistule" developments and mucus production ( $C$. incrustans and G. dumosa, respectively). These active and passive mechanisms can use energy that is stored for other processes like growth and reproduction (Bell et al., 2015; Erftemeijer et al., 2012). Understanding the potential energetic loss that these species might experience in response to high SSCs, and the way reproduction and growth, in turn, can be affected, deserve more investigation. 


\subsubsection{Cumulative impacts}

Both shallow and deep-sea environments are expected to face other impacts co-occurring with high SSC. For example, coastal waters may experience an excess of nutrients along with high SSCs; bottom-contact fishing activities and deep-sea mining operations can release contaminants into the water column along with the generation of sediment plumes (RamirezLlodra et al., 2011; Bradshaw et al., 2012; Hauton et al., 2017); both shallow and deep-sea waters also face the effects of climate change (Levin \& Le Bris, 2015). The combination of stressors can have negative impacts on sponges and corals when the action of the single stressor does not (e.g. see Scanes et al., 2018), thus, for future research, it will be crucial to consider cumulative impacts of high SSC and other stressors.

\subsection{Management implications and concluding remarks}

Anthropogenic activities operating on the seafloor, particularly bottom fishing activities and, potentially, deep-sea mining, cause physical disturbance of the seabed and can generate sediment plumes that will disperse beyond the actual footprint of the direct operations (Boschen et al., 2013). Elevated suspended sediment concentrations are known to have negative impacts on benthic fauna, particularly on suspension feeders like sponges and corals (Fabricius, 2005; Bell et al., 2015; Erftemeijer et al., 2012). Given the potential for adverse effects of high SSCs on sensitive marine fauna, the monitoring and management of those activities that elevate sediment re-suspension is critical. In recent decades, coastal states and regional fisheries management organizations worldwide have introduced regulations which limit or ban fishing operations in sensitive areas such as seamounts and ridges (Morato et al., 2010), including in New Zealand (Brodie and Clark, 2004, Helson et al., 2010), or below certain depths (Tudela et al., 2004), however, regulations based on the sediment concentrations in the water columns and the stress duration are generally absent.

This thesis indicates that the New Zealand species Crella incrustans, Ecionemia novaezealandiae and Goniocorella dumosa showed very high or complete survival when temporarily exposed to elevated SSCs that might be experienced under intense anthropogenic pressure. However, E. novaezealandiae and G. dumosa, showed a deterioration in health conditions over time, while $C$. incrustans did not show signs of degeneration over the time span of the experiment. So while direct mortality from short-term exposure to sediment clouds generated by these activities might not in itself be a major concern, more longer-term changes 
in their health may be, especially if exposure to higher suspended sediment levels over longer time periods occur. As E. novaezealandiae and G. dumosa are abundant on the Chatham Rise, which is an area subject to intense bottom-contact fishing activities and a proposed area for mineral extraction, it is important to consider management options to minimize adverse impacts on these species.

My results show that different SSCs could be important in determining E. novaezealandiae health condition (Chapter 3). After two weeks of suspended sediment exposure, partial necrosis affected sponges in the 100 and $500 \mathrm{mg}^{-1} \mathrm{SSC}$, and mortality occurred in one sponge in the $500 \mathrm{mg} \mathrm{l}^{-1} \mathrm{SSC}$ treatment (12\%), while no signs of deterioration were observed in specimens exposed to $50 \mathrm{mg}^{-1}$. These results suggest that the re-suspension of SSCs $\geq 100 \mathrm{mg}^{-1}$ should be avoided if the sediment stress persists for a duration of 14 days.

In G. dumosa, the duration of the sediment exposure seems to be more influential than the SSCs in determining coral health. My results show that corals did not show coenosarc loss after one four-day cycle of sediment exposure, but corals of all sediment treatments were affected by partial coenosarc loss from the second sediment pulse onward, and also showed partial polyp mortality (Chapter 4). These results, along with the results of Chapter 5 that suggest that $G$. dumosa might stop feeding for the whole duration of sediment exposure, even at the low SSC (50 $\mathrm{mg} \mathrm{l}^{-1}$ ), suggest that sediment stress duration longer than 4 days could decrease coral health. The combined results of Chapter 3,4 and 5 indicate that activities that re-suspend large amount of sediments should be carefully managed both spatially and temporally to prevent impacts on E. novaezealandiae and G. dumosa populations, when these activities operate in areas close to these species. Bottom-contact fishing activities and potential deep-sea mining should not operate continuously for periods longer than 4 days in the same area (where sediment clouds would disperse over these coral and sponge species), and preferably should not expose coral and sponge populations to re-suspended sediment exceeding concentrations

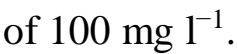

Deltares (2014) proposed a mining plan for the Chatham Rise consisting of areas not interested by mining operations, surrounded by tracks to be mined for approximatively four-day cycles, with waiting periods of five days between cycles where mining does not take place. This proposed plan would not be suitable as longer waiting periods would be necessary between mining cycles to minimize impacts on benthic fauna. A mining operation option could be that to mine "strips" of seafloor, e.g. long and narrow areas, so that the sediment resuspension would not persist on the same area for prolonged periods. The strips would be spaced out 
between each other based on sediment dispersal rates of $100 \mathrm{mg}^{-1}$. Each mining cycle would run for a maximum period of four days on the same area, after which the area would be temporally closed for at least 20 days before the next mining cycle. With the proposed plan, mining operations would move to different mining areas after each mining cycle, rather than completing several mining cycles, and persisting, on the same area for prolonged periods. Similar options could be applied by bottom-contantc fishing operations, with temporal closures of fishing grounds after each four-days period of fishing activities.

Such management decisions, however, cannot be made based on the results of this Thesis alone. While I investigated the effects of elevated sediment concentrations only sponges and a coral species, this Thesis is part of a larger project that will generate such management advice. 


\section{References}

Allers, E., Abed, R.M., Wehrmann, L.M., Wang, T., Larsson, A.I., Purser, A., de Beer, D. (2013). Resistance of Lophelia pertusa to coverage by sediment and petroleum drill cuttings. Marine Pollution Bulletin, 74, 132-140.

Anthony, K.R., \& Fabricius, K.E. (2000). Shifting roles of heterotrophy and autotrophy in coral energetics under varying turbidity. Journal of Experimental Marine Biology and Ecology, 252, 221-253.

Anthony, K.R., Connolly, S. R., Hoegh-Guldberg, O. (2007). Bleaching, energetics, and coral mortality risk: Effects of temperature, light, and sediment regime. Limnology and Oceanography, 52, 716-726.

Babcock, R., \& Smith, L. (2000). Effects of sedimentation on coral settlement and survivorship. Proceedings of the Ninth International Coral Reef Symposium, 23-27 1, 245-248.

Bannister, R.J., Battershill, C.N., \& De Nys, R. (2012). Suspended sediment grain size and mineralogy across the continental shelf of the Great Barrier Reef: Impacts on the physiology of a coral reef sponge. Continental Shelf Research, 32, 86-95.

Bell, J.J., McGrath, E., Biggerstaff, A., Bates, T., Bennett, H., Marlow, J., \& Shaffer, M. (2015). Sediment impacts on marine sponges. Marine Pollution Bulletin, 94, 5-13.

Bell, J.J. (2004). Evidence for morphology-induced sediment settlement prevention on the tubular sponge Haliclona urceolus. Marine Biology, 146, 29-38.

Bell, J.J., Barnes, D.K.A., Shaw, C. (2002). Branching dynamics of two species of arborescent demosponge: the effect of flow regime and bathymetry. Marine Biological Association of the United Kingdom. Journal of the Marine Biological Association of the United Kingdom, 82, 279.

Biggerstaff, A., Smith, D.J., Jompa, J., Bell, J.J. (2017). Metabolic responses of a phototrophic sponge to sedimentation supports transitions to sponge-dominated reefs. Scientific Reports, 7, $1-11$.

Birrell, C.L., McCook, J.L., Willis, B.L. (2005) Effects of algal turfs and sediment on coral settlement. Marine Pollution Bulletin, 51, 408-414.

Boschen, R.E., Rowden, A.A., Clark, M.R., Gardner, J.P.A. (2013). Mining of deep-sea seafloor massive sulfides: a review of the deposits, their benthic communities, impacts from 
mining, regulatory frameworks and management strategies. Ocean \& Coastal Management, 84, $54-67$.

Bradshaw, C., Tjensvoll, I., Sköld, M., Allan, I.J., Molvaer, J., Magnusson, J., Naes, K., Nilsson, H.C. (2012). Bottom trawling resuspends sediment and releases bioavailable contaminants in a polluted fjord. Environmental Pollution, 170, 232-241.

Brown, B., \& Bythell, J. (2005). Perspectives on mucus secretion in reef corals. Marine Ecology Progress Series, 296, 291-309. doi: 10.3354/meps296291

Cerrano, C., Calcinai, B., Di Camillo, C. G., Valisano, L., Bavestrello, G. (2007). How and why do sponges incorporate foreign material? Strategies in Porifera. Porifera Research: Biodiversity, Innovation and Sustainability. Série Livros, 28, 239-246.

Cerrano, C., Pansini, M., Valisano, L., Calcinai, B., Sara, M., Bavestrello, G. (2004). Lagoon sponges from carrie bow cay (Belize): ecological benefits of selective sediment incorporation. BMIB-Bollettino dei Musei e degli Istituti Biologici, 68.

Crossland, C.J. (1987). In situ release of mucus and DOC-lipid from the coral Acropora variabilis and Stylophora pistillata. Coral Reefs 6, 35-42.

Deltares (2014). Modelling investigations on mine tailing plume dispersion on the Chatham Rise. Deltares Final Report 1209110-000-ZKS-0007, 57 pp.

Edmunds, P.J., \& Davies, P.S. (1989). An energy budget for Porites porites (Scleractinia), growing in a stressed environment. Coral Reefs, 8, 37-43.

Erftemeijer, P. L., Riegl, B., Hoeksema, B. W., Todd, P. A. (2012). Environmental impacts of dredging and other sediment disturbances on corals: a review. Marine Pollution Bulletin, 64, $1737-1765$.

Fabricius, K.E. (2005). Effects of terrestrial runoff on the ecology of corals and coral reefs: review and synthesis. Marine Pollution Bulletin, 50, 125-146.

Gilmour, J. (1999). Experimental investigation into the effects of suspended sediment on fertilisation, larval survival and settlement in a scleractinian coral. Marine Biology, 135, 451462. 
Goh, B.P.L., \& Lee, C.S. (2008). A study of the effect of sediment accumulation on the settlement of coral larvae using conditioned tiles. In: Proceedings Eleventh International Coral Reef Symposium, Ft. Lauderdale, Florida, 7-11 July 2008, 1235-1239.

Hauton, C., Brown, A., Thatje, S., Mestre, N.C., Bebianno, M.J., Martins, I., Bettencourt, R., Canals, M., Sanchez-Vidal, A., Shillito, B., Ravaux, J., Zbinden, M., Duperron, S., Mevenkamp, L., Vanreusel, A., Gambi, C., Dell'Anno, A., Danovaro, R., Gunn, V., Weaver, P. (2017). Identifying toxic impacts of metals potentially released during deep-sea mining-a synthesis of the challenges to quantifying risk. Frontiers in Marine Science, 4, 368.

Hoegh-Guldberg, O. (1999). Climate change, coral bleaching and the future of the world's coral reefs. Marine Freshwater Research, 50, 839-866.

Järnegren, J., Brooke, S., Jensen, H. (2017). Effects of drill cuttings on larvae of the cold-water coral Lophelia pertusa. Deep Sea Research Part II: Topical Studies in Oceanography, 137, $454-462$.

Jones, R., Bessell-Browne, P., Fisher, R., Klonowski, W., \& Slivkoff, M. (2016). Assessing the impacts of sediments from dredging on corals. Marine Pollution Bulletin, 102, 9-29.

Larsson, A.I., Purser, A., 2011. Sedimentation on the cold-water coral Lophelia pertusa: Cleaning efficiency from natural sediments and drill cuttings. Marine Pollution Bulletin, 62, $1159-1168$.

Larsson, A.I., van Oevelen, D., Purser, A., Thomsen, L. (2013). Tolerance to long-term exposure of suspended benthic sediments and drill cuttings in the cold-water coral Lophelia pertusa. Mar. Poll. Bull. http://dx.doi.org/10.1016/ j.marpolbul. 02.033.

Levin, L. A., \& Le Bris, N. (2015). The deep ocean under climate change. Science, 350, 766768.

Maldonado, M., Giraud, K., Carmona, C. (2008). Effects of sediment on the survival of asexually produced sponge recruits. Marine Biology, 154, 631-641.

McGrath, E.C., Smith, D.J., Jompa, J., Bell, J.J. (2017). Adaptive mechanisms and physiological effects of suspended and settled sediment on barrel sponges. Journal of Experimental Marine Biology and Ecology, 496, 74-83. 
Morato, T., Pitcher, T.J., Clark, M.R., Menezes, G., Tempera, F., Porteiro, F., Giacomello, E., Santos, R.S. (2010). Can we protect seamounts for research? A call for conservation. Oceanography, 23, 190-199.

Pineda, M.C., Strehlow, B., Sternel, M., Duckworth, A., Jones, R., Webster, N.S. (2017). Effects of suspended sediments on the sponge holobiont with implications for dredging management. Scientific Reports, 7, 1-15.

Ramirez-Llodra, E., Tyler, P.A., Baker, M.C., Bergstad, O.A., Clark, M.R., Escobar, E., Levin, L.A., Menot, L., Rowden A.A., Smith, C.R., Van Dover, C.L. (2011). Man and the last great wilderness: human impact on the deep sea. PloS One, 6, e22588.

Riegl, B., \& Branch, G.M. (1995). Effects of sediment on the energy budgets of four scleractinian (Bourne 1900) and five alcyonacean (Lamouroux 1816) corals. Journal of Experimental Marine Biology and Ecology, 186, 259-275.

Rix, L., de Goeij, J.M., Mueller, C.E., Struck, U., Middelburg, J.J., van Duyl, F.C., Al-Horani, F.A., Wild, C., Naumann, M.S., van Oevelen, D. (2016). Coral mucus fuels the sponge loop in warm-and cold-water coral reef ecosystems. Scientific Reports, 6, 1-11.

Roberts, D.E., Davis, A.R., Cummins, S.P. (2006). Experimental manipulation of shade, silt, nutrients and salinity on the temperate reef sponge Cymbastela concentrica. Marine Ecology Progress Series, 307, 143-154.

Robertson, L.M., Hamel, J.F., Mercier, A. (2017). Feeding in deep-sea demosponges: Influence of abiotic and biotic factors. Deep Sea Research Part I: Oceanographic Research Papers, 127, $49-56$.

Rogers, C.S. (1990). Responses of coral reefs and reef organisms to sedimentation. Marine Ecology Progress Series, 62, 185-202.

Rosenfield, M., Bresler, V., Abelson, A. (1999). Sediment as a possible source of food for corals. Ecology Letters, 2, 345-348.

Scanes, E., Kutti, T., Fang, J.K., Johnston, E.L., Ross, P.M., Bannister, R.J. (2018). Mine waste and acute warming induce energetic stress in the deep-sea sponge Geodia atlantica and coral Primnoa resedeaformis; results from a mesocosm study. Frontiers in Marine Science, 5, 129. 
Schönberg, C.H.L. (2016). Happy relationships between marine sponges and sediments-a review and some observations from Australia. Journal of Marine Biological Association of the United Kingdom, 96, 493-514.

Tompkins-MacDonald, G.J., \& Leys, S.P. (2008). Glass sponges arrest pumping in response to sediment: implications for the physiology of the hexactinellid conduction system. Marine Biology, 154, 973-984.

Stafford-Smith, M.G. (1993). Sediment-rejection efficiency of 22 species of Australian scleractinian corals. Marine Biology, 115, 229-243.

Tudela, S., Simard, F., Skinner, J., Guglielmi, P. (2004). The Mediterranean deep-sea ecosystems: a proposal for their conservation. In: WWF. I, ed. The Mediterranean deep-sea ecosystems: an overview of their diversity, structure, functioning and anthropogenic impacts, with a proposal for conservation. Málaga \& Rome: IUCN Publications Services. pp 39-47.

Wahab, M.A.A., Maldonado, M., Luter, H.M., Jones, R., Ricardo, G. (2019). Effects of sediment resuspension on the larval stage of the model sponge Carteriospongia foliascens. Science of The Total Environment, 695, 133837.

Whalan, S., Battershill, C., de Nys, R. (2007). Variability in reproductive output across a water quality gradient for a tropical marine sponge. Marine Biology, 153, 163-169.

Wild, C., Huettel, M., Klueter, A., Kremb, S.G., Rasheed, M.Y.M., Jørgensen, B.B. (2004). Coral mucus functions as an energy carrier and particle trap in the reef ecosystem. Nature, 428, $66-70$.

Yahel, G., Whitney, F., Reiswig, H.M., Eerkes-Medrano, D.I., Leys, S.P. (2007). In situ feeding and metabolism of glass sponges (Hexactinellida, Porifera) studied in a deep temperate fjord with a remotely operated submersible. Limnology and Oceanography, 52, 428-440.

Zetsche, E.M., Baussant, T., Meysman, F.J., van Oevelen, D. (2016). Direct visualization of mucus production by the cold-water coral Lophelia pertusa with digital holographic microscopy. PloS one, 11(2), e0146766. https://doi.org/10.1371/journal.pone.0146766. 
Appendices 


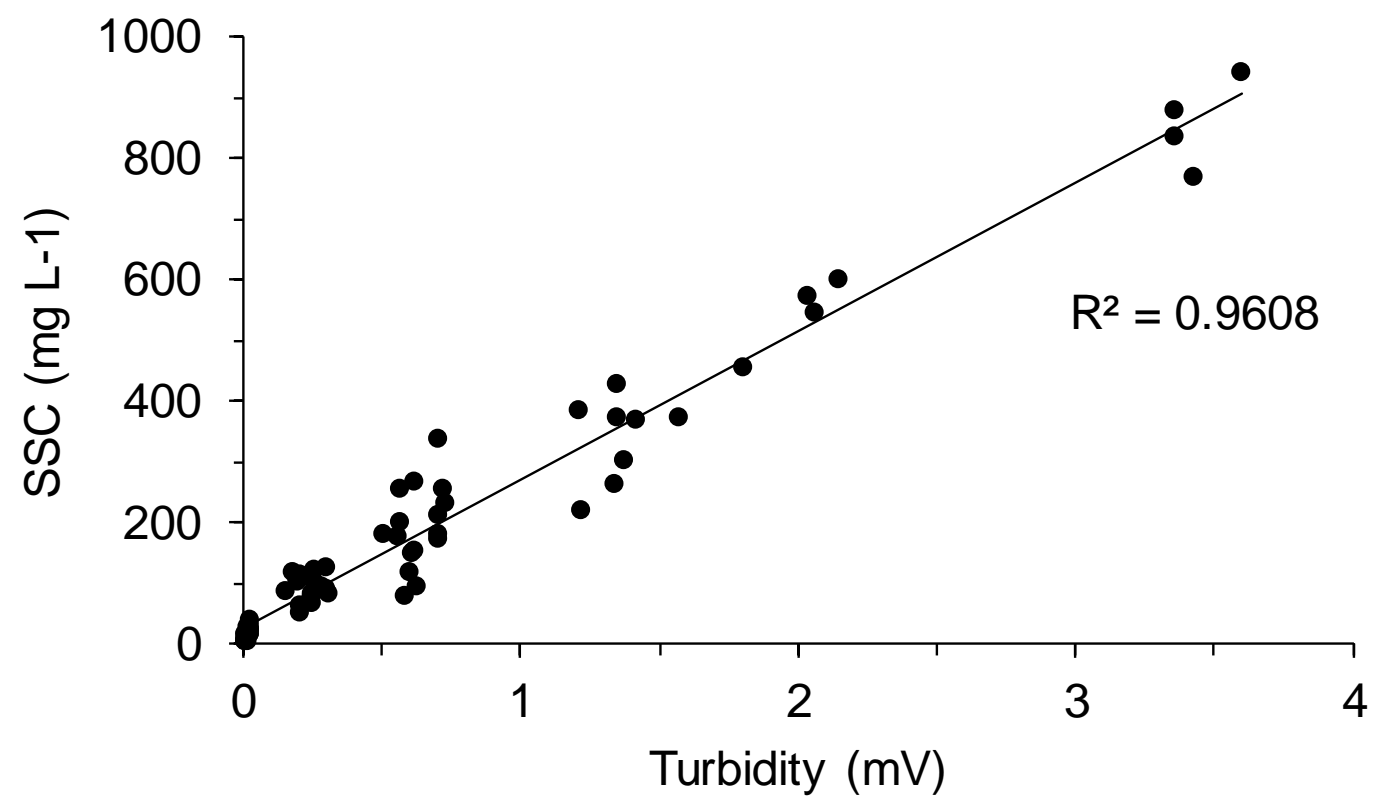

Figure A1.1. Scatterplot and linear regression of the relationship between voltage and SSCs determined prior to the experiment. $\mathrm{y}=25.532+245.1305 \mathrm{x}$. 


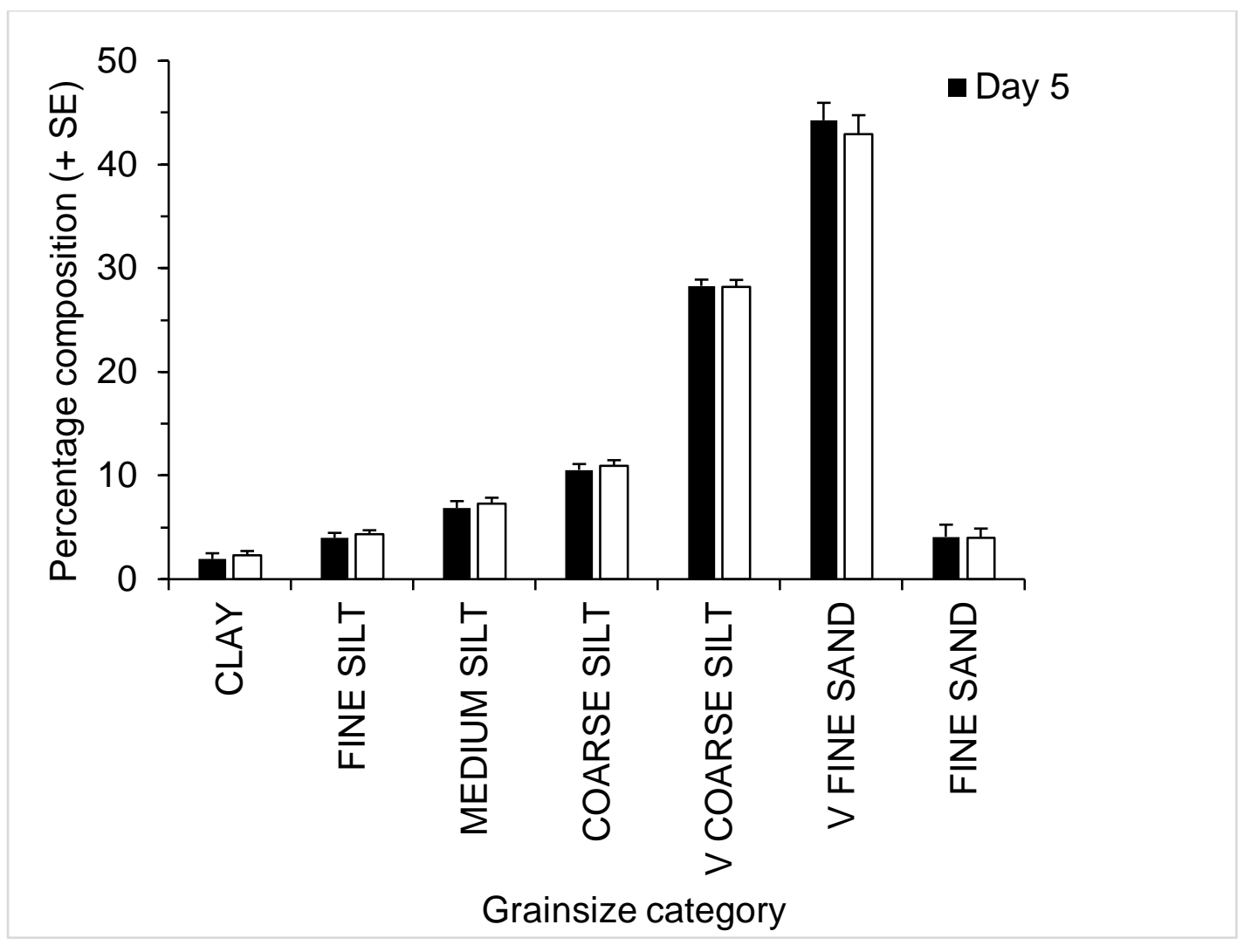

Figure A1.2. Particle size distribution (\% composition) of suspended sediments in high SSC chambers, near the beginning (Day 5) and end (Day 29) of the elevated SSC portion of the experiment. An average of five chambers (SE) are presented on each sampling date. Distribution categories equate to particle sizes generated in GRADISTAT: Clay $<4 \mu \mathrm{m}$, Fine silt 4-8 $\mu \mathrm{m}$, Medium silt 8-16 m, Coarse silt 16-31 $\mu \mathrm{m}$, Very coarse silt 31-63 $\mu \mathrm{m}$, Very fine sand 63-125 $\mu \mathrm{m}$, Fine sand 125-250 $\mu \mathrm{m}$. 


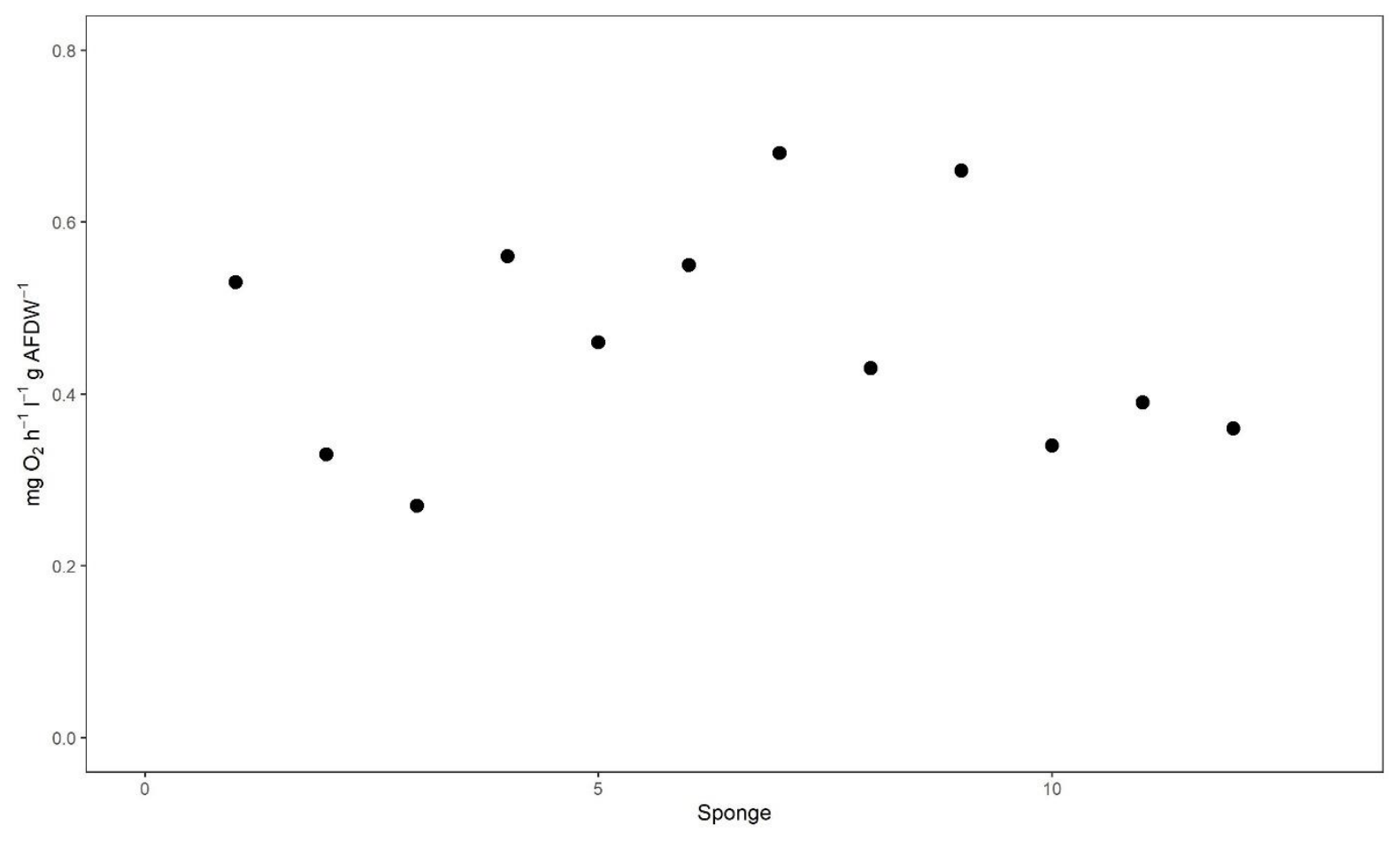

Figure A1.3. Baseline respiration rates of Crella incrustans measured in $\mathrm{N}=12$ extra sponge samples before the experiment start. 


\section{Appendix two}

Table A2.1. Linear mixed model results of the random effects "Sponge" and "Chamber" for A) respiration rates and $\mathrm{B}$ ) sediment coverage. $\mathrm{SD}=$ Standard deviation.

\begin{tabular}{lll}
\hline Random effect & Variance & SD \\
\hline A) Respiration rates & & \\
\hline Sponge & $<0.001$ & 0.0033 \\
Chamber & 0.000 & 0.0000 \\
Residual & $<0.001$ & 0.0175 \\
\hline B) Sediment coverage & & \\
\hline Sponge & 211.5 & 14.54 \\
Chamber & 0.0 & 0.00 \\
Residual & 413.8 & 20.34 \\
\hline
\end{tabular}

Table A2.2. Tukey post hoc pairwise comparison between SSC treatments, SSC treatments*Time and Time for sponge respiration rates.

\begin{tabular}{|c|c|c|}
\hline & Treatment (SSC) & $\mathrm{p}$ \\
\hline & $0-50$ & 0.7284 \\
\hline & $0-100$ & 0.2357 \\
\hline & $0-500$ & 0.037 \\
\hline & $50-100$ & 0.8319 \\
\hline & $50-500$ & 0.2391 \\
\hline & $100-500$ & 0.6275 \\
\hline \multirow{6}{*}{$\mathrm{T}_{1}$} & $0-50$ & 0.9372 \\
\hline & $0-100$ & 0.5937 \\
\hline & $0-500$ & 0.0406 \\
\hline & $50-100$ & 0.9995 \\
\hline & $50-500$ & 0.5918 \\
\hline & $100-500$ & 0.8165 \\
\hline \multirow{7}{*}{ Tend } & $0-50$ & 1 \\
\hline & $0-100$ & 0.9863 \\
\hline & $0-500$ & 0.9751 \\
\hline & $50-100$ & 0.993 \\
\hline & $50-500$ & 0.9849 \\
\hline & $100-500$ & 1 \\
\hline & Time (day) & \\
\hline
\end{tabular}




\begin{tabular}{lll} 
& $1-14$ & 0.0712 \\
\hline & Treatment (SSC) & $\mathbf{p}$ \\
\hline & $0-50$ & 0.7284 \\
$0-100$ & 0.2357 \\
& $0-500$ & $\mathbf{0 . 0 3 7 0}$ \\
$50-100$ & 0.8319 \\
& $50-500$ & 0.2391 \\
& $100-500$ & 0.6275 \\
\hline \multirow{4}{*}{$\mathrm{T}_{1}$} & $0-50$ & 0.9372 \\
& $0-100$ & 0.5937 \\
& $0-500$ & $\mathbf{0 . 0 4 0 6}$ \\
& $50-100$ & 0.9995 \\
& $50-500$ & 0.5918 \\
& $100-500$ & 0.8165 \\
\hline \multirow{4}{*}{$\mathrm{T}_{\text {end }}$} & $0-50$ & 1.0000 \\
& $0-100$ & 0.9863 \\
& $0-500$ & 0.9751 \\
& $50-100$ & 0.9930 \\
& $50-500$ & 0.9849 \\
& $100-500$ & 1.0000 \\
\hline & Time (day) & \\
\hline & $1-14$ & 0.0712 \\
\hline
\end{tabular}

Table A2.3. Tukey post hoc pairwise comparison between A) SSC treatments and B) Time for sponge sediment coverage.

\begin{tabular}{ll}
\hline Treatment (SSC) & $\mathrm{p}$ \\
\hline $0-50$ & $\mathbf{0 . 0 1 3 0}$ \\
$0-100$ & $\mathbf{0 . 0 0 2 3}$ \\
$0-500$ & $\mathbf{0 . 0 0 0 2}$ \\
$50-100$ & 0.8132 \\
$50-500$ & 0.1451 \\
$100-500$ & 0.5143 \\
\hline Time (day) & \\
\hline 1-14 & $\mathbf{0 . 0 0 6 2}$ \\
\hline
\end{tabular}




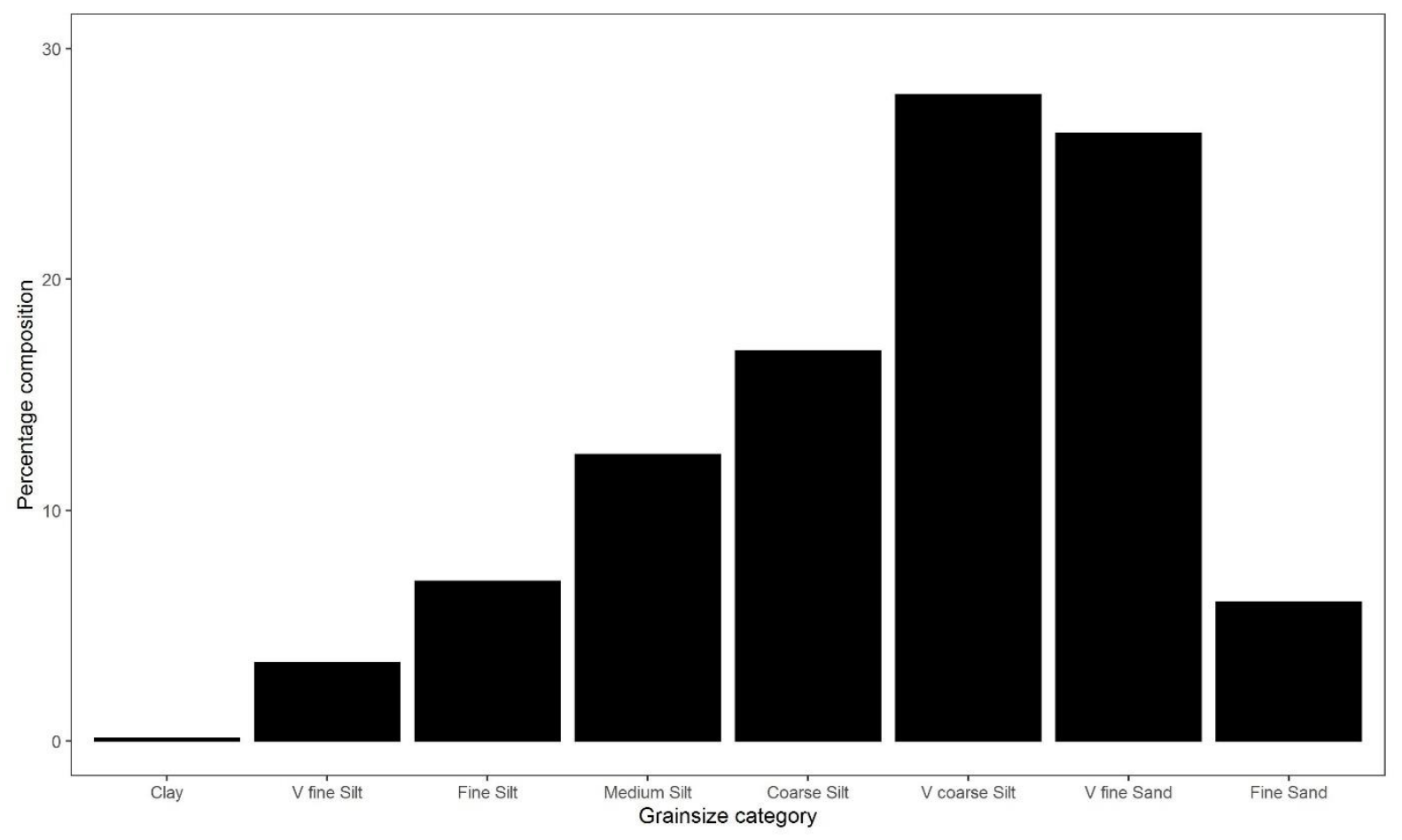

Figure A2.1. Particle size distribution (\% composition) of sediments used in the experiment. Distribution categories correspond to particle sizes generated in GRADISTAT: Clay $<2 \mu \mathrm{m}$, Very fine silt 2-4 $\mu \mathrm{m}$, Fine silt 4-8 $\mu \mathrm{m}$, Medium silt 8-16 $\mu \mathrm{m}$, Coarse silt 16-31 $\mu \mathrm{m}$, Very coarse silt 31-63 $\mu \mathrm{m}$, Very fine sand 63-125 $\mu \mathrm{m}$, Fine sand 125-250 $\mu \mathrm{m}$. 


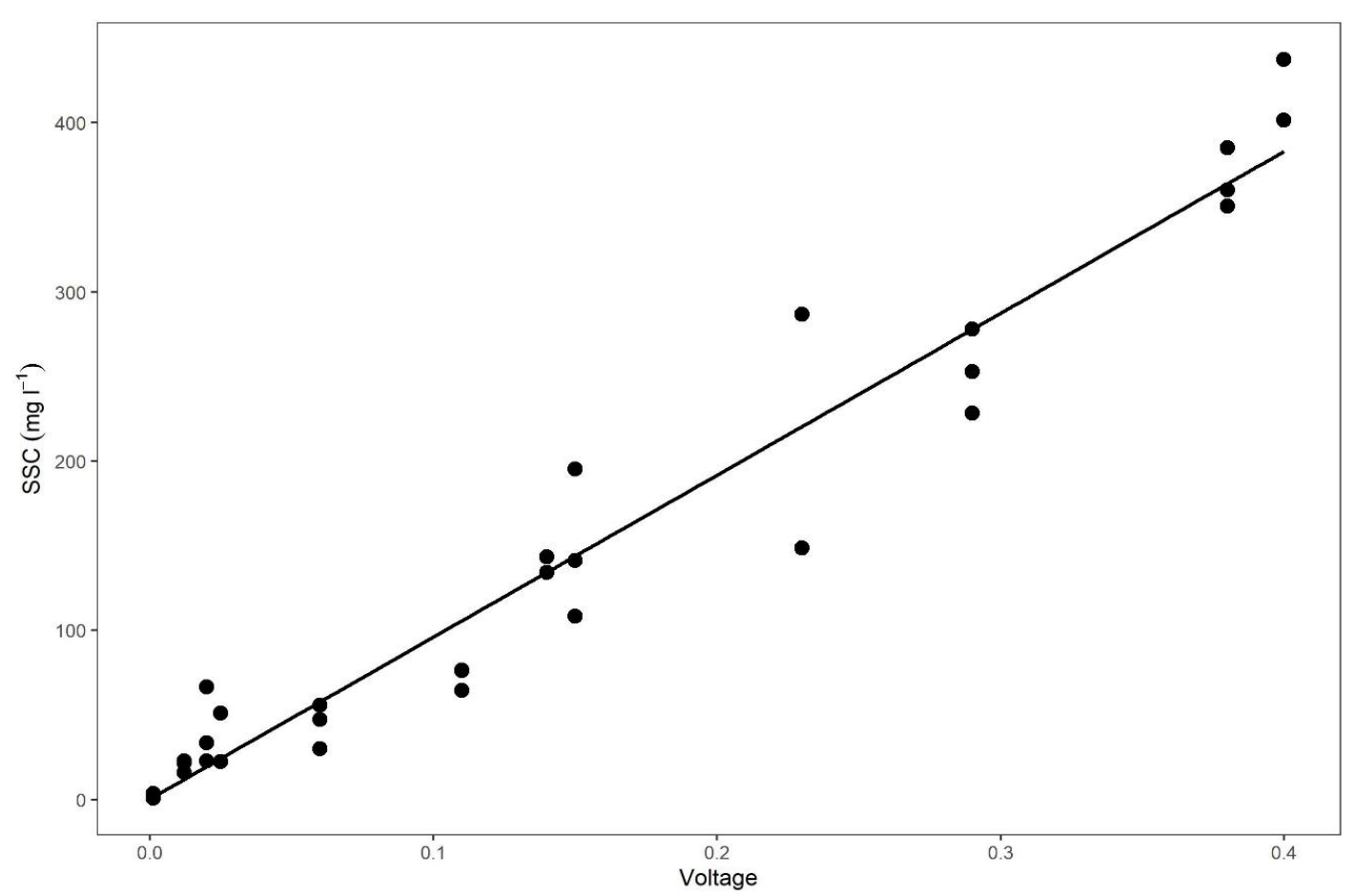

Figure A2.2. Scatterplot and linear regression of the relationship between voltage and SSCs. $y=0.3061+956.97 x \cdot R^{2}=0.95$.

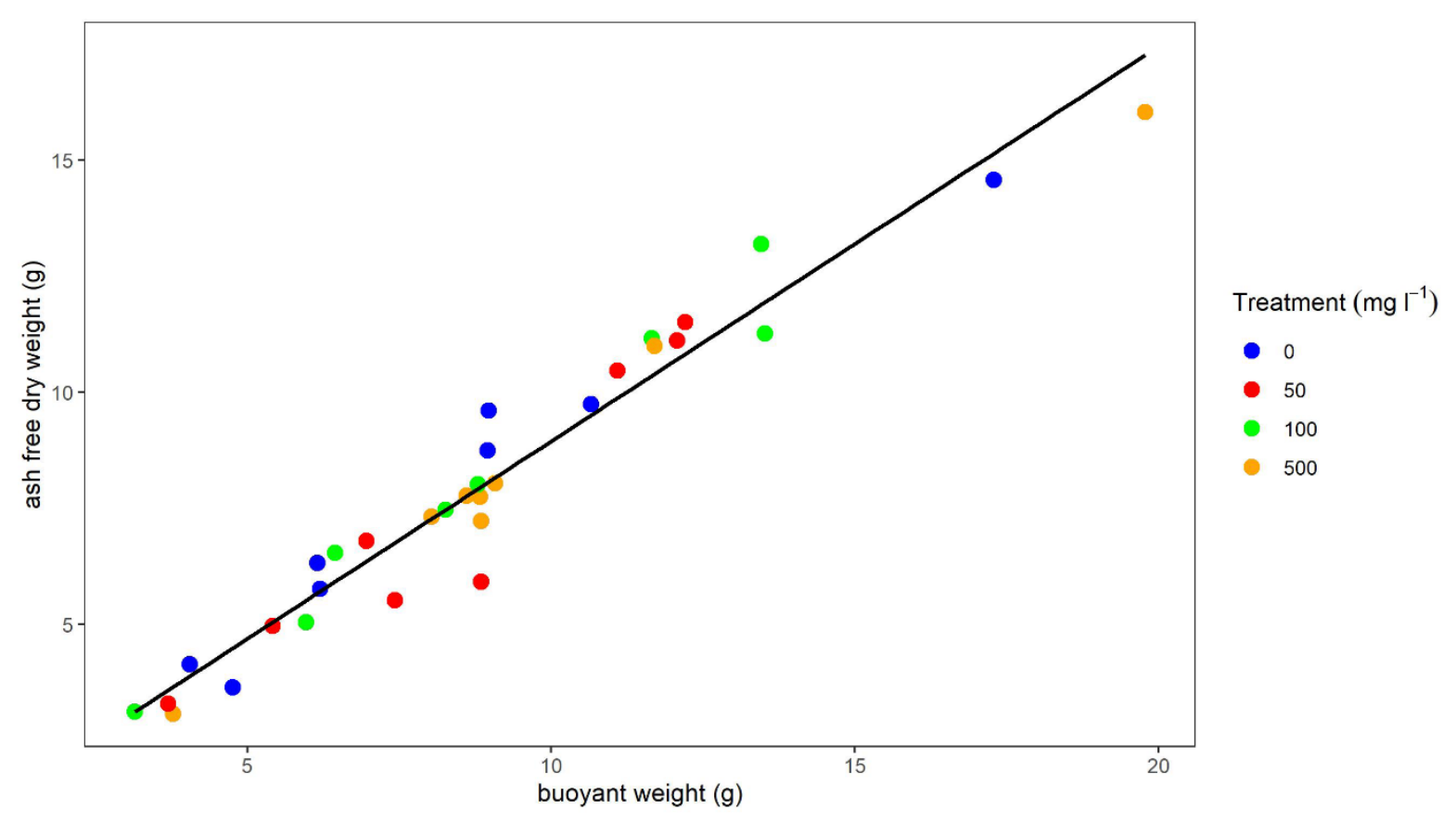

Figure A2.3. Scatterplot and linear regression fitted line of ash free dry weights $(\mathrm{g})$ as a function of buoyant weight ( $\mathrm{g}$ ) obtained from experimental sponges at $\mathrm{T}_{\text {end. }} \cdot \mathrm{R}^{2}=0.94$. $\mathrm{Y}=$ $0.44063+0.85049 x$. Colours represent sponges from different treatments $(\mathrm{N}=8)$. 


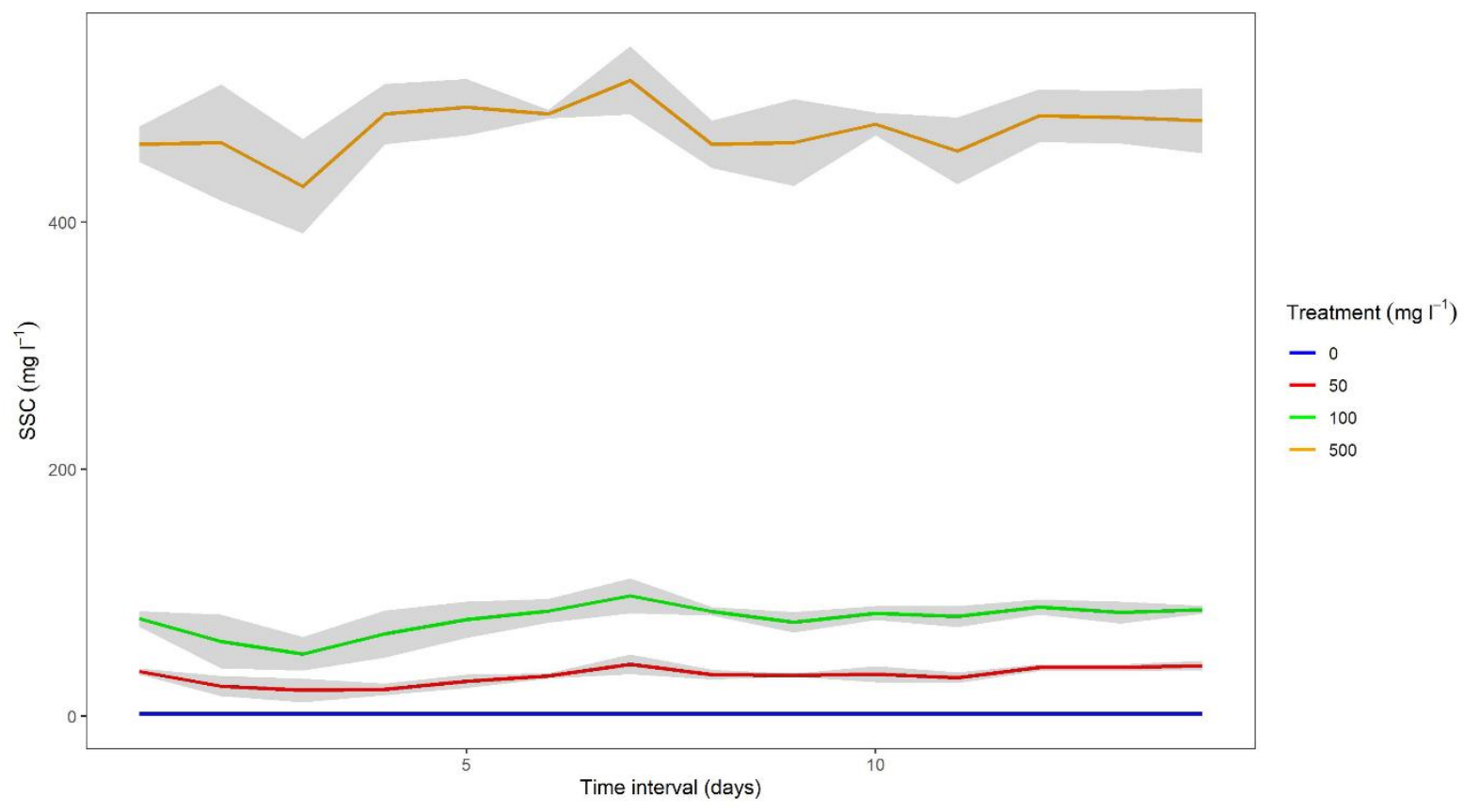

Figure A2.4. Suspended sediment concentrations over the 14-day experimental period. SSCs were derived from twice daily turbidity measurements, via the calibration curve shown in Figure A2.2. Lines and shaded areas indicate mean values (SD). 


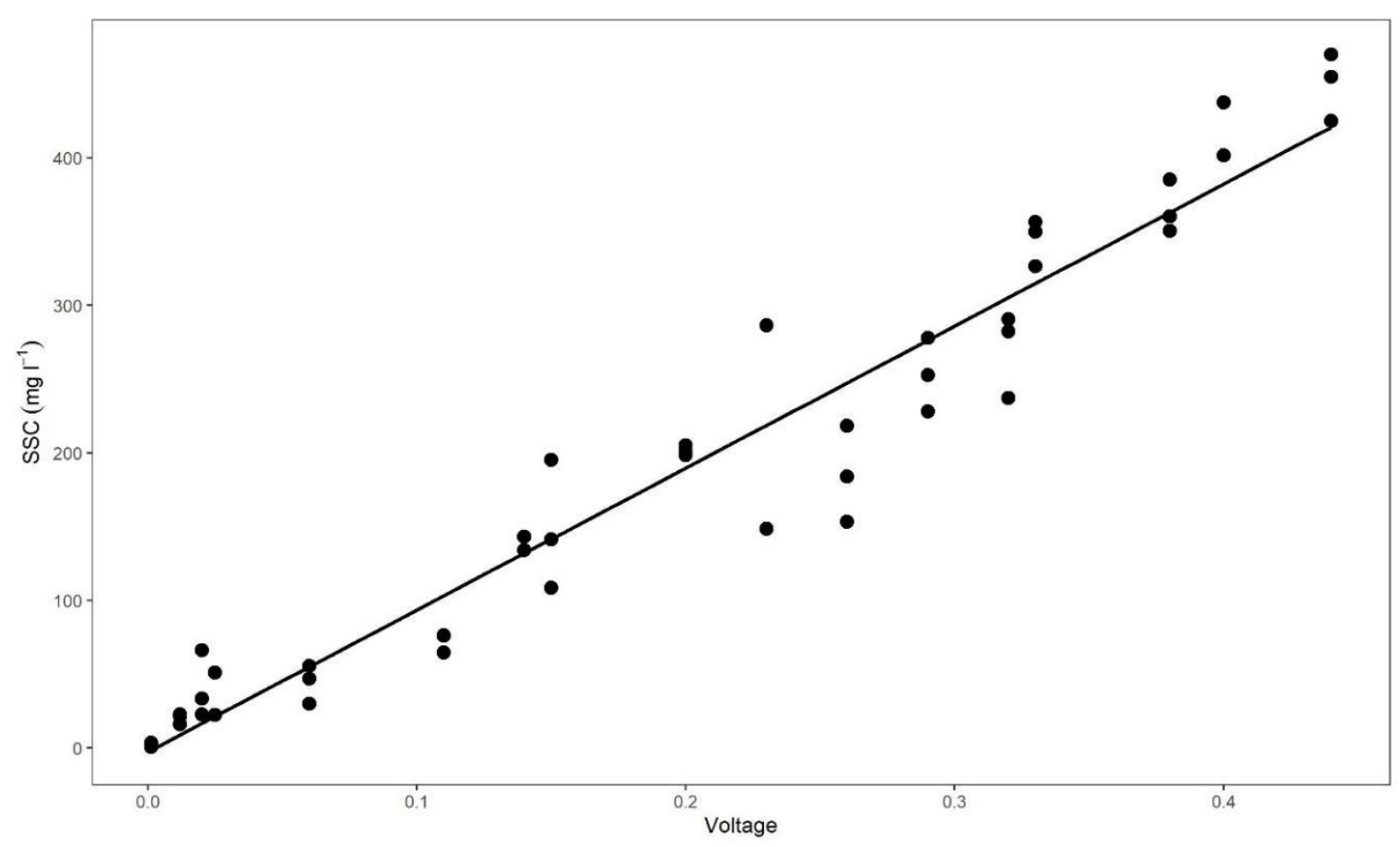

Figure A3.1. Scatterplot and linear regression fitted line of the relationship between voltage and SSCs. $y=-2.674+962.096 x . R^{2}=0.94$.

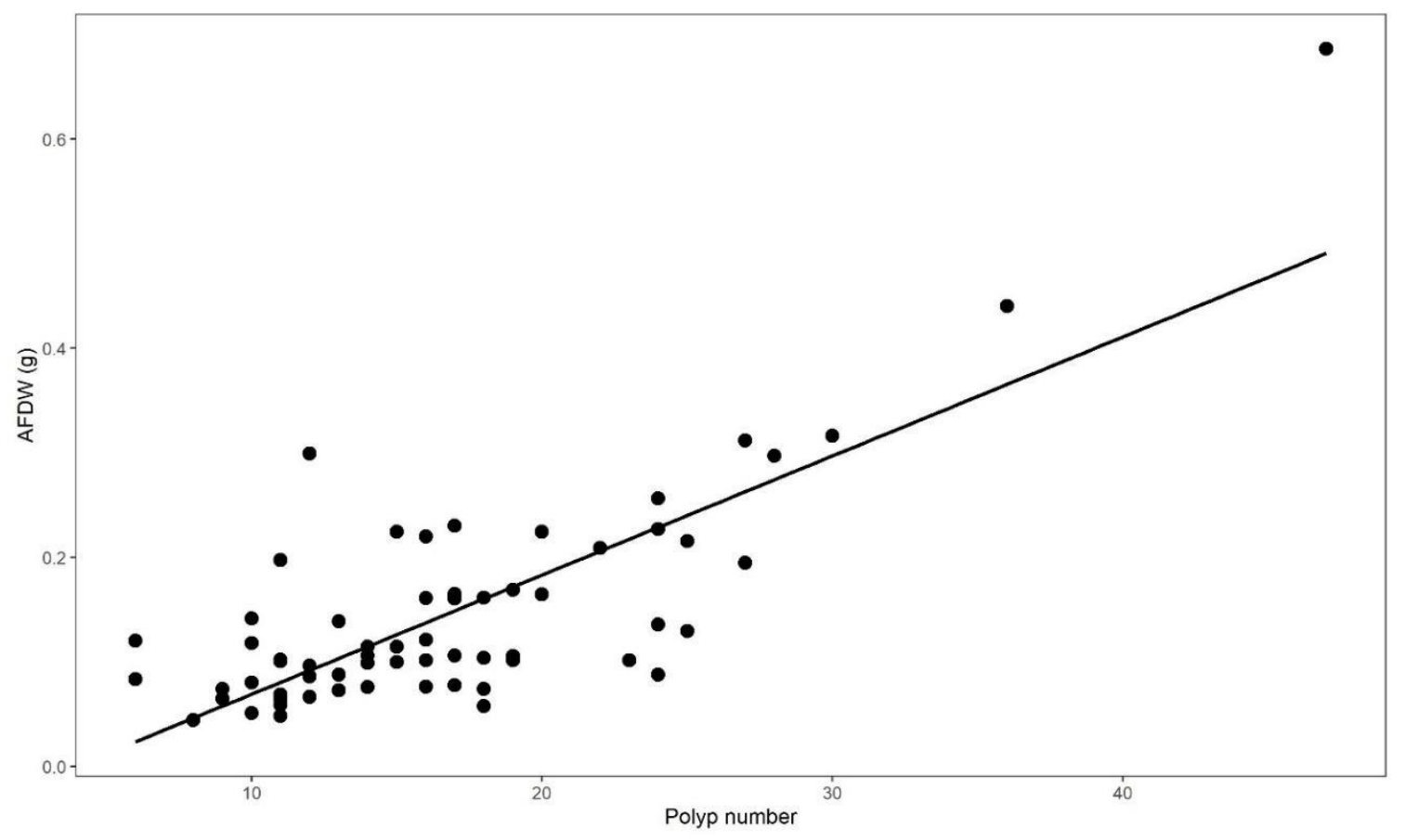

Figure A3.2. Scatterplot and linear regression fitted line of ash free dry weights ( $g$ ) as a function of polyp number. $R^{2}=0.61$. $Y=-0.04462+0.01139 x$. 


\title{
Responses of a common New Zealand coastal sponge to elevated suspended sediments: Indications of resilience
}

\author{
Vonda J. Cummings ${ }^{\mathrm{a}, *}$, Jennifer Beaumont ${ }^{\mathrm{a}}$, Valeria Mobilia ${ }^{\mathrm{b}}$, James J. Bell ${ }^{\mathrm{b}}$, Dianne Tracey ${ }^{\mathrm{a}}$, \\ Malcolm R. Clark ${ }^{\mathrm{a}}$, Neill Barr ${ }^{\mathrm{a}}$

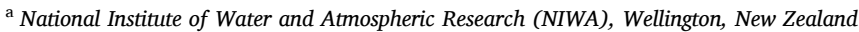 \\ ${ }^{\mathrm{b}}$ School of Biological Sciences, Victoria University of Wellington, New Zealand
}

\section{A R T I C L E I N F O}

\section{Keywords:}

Marine

Crella incrustans

Physiology

Temperate

Demospongiae

Porifera

\begin{abstract}
A B S T R A T
Suspended sediments can affect the health of marine benthic suspension feeders, with concomitant effects on community diversity, abundance and ecosystem function. Suspended sediment loads can become elevated through trawling and dredging, and via resuspension of bottom sediments and/or direct input from land during storms. We assessed the functioning (survival, respiration, morphology) of a common New Zealand cushion sponge, Crella incrustans (Carter, 1885), during four weeks of exposure to a gradient of suspended sediment concentrations (SSC). Survival was high, and oxygen consumption was not affected. Sponges did, however, develop apical fistules, a phenomenon never-before observed in this species. Although sediments accumulated internally within the sponges, around a third had cleared these sediments two weeks after the elevated SSCs were removed. The environments these sponges inhabit may predispose them to coping with high SSCs. Such experiments are useful for defining SSC tolerances, which may influence how such impacts can be managed.
\end{abstract}

\section{Introduction}

Coastal marine environments are under increasing pressure from many natural and anthropogenic impacts operating at a range of temporal and spatial scales (Crain et al., 2009; Halpern et al., 2015). Of concern globally is the increasing amount of sediment entering coastal systems through waterways as a result of changes in land use, deforestation, and agricultural practices (Airoldi, 2003; Syvitski et al., 2005), and being disturbed and redistributed in situ from activities such as coastal and offshore dredging, trawling and seabed mining (Erftemeijer et al., 2012; Levin et al., 2016; Paradis et al., 2018). While many organisms are able to withstand natural levels of suspended and deposited sediment in coastal regions (Larcombe et al., 1995; Wolanski et al., 2005; Storlazzi et al., 2009), sustained high sediment loads can impact the health of marine organisms and, therefore, overall ecosystem function (Thrush and Dayton, 2002).

While larger sediment particles tend to settle quickly after suspension, fine particles can remain in suspension for extended periods and be transported over long distances by currents (Capuzzo et al., 1985; Rolinski et al., 2001). This means the impact of high suspended sediment concentrations (SSC) can occur some distance from the sediment disturbance source (Oebius et al., 2001; Fisher et al., 2015; Jones et al., 2019). Excessive sedimentation and sediment resuspension can significantly affect the abundance, diversity and structure of benthic communities (Airoldi, 2003; Fabricius, 2005; Carballo, 2006; Knapp et al., 2013). These effects range from burial and smothering by settling sediment, which can be fatal, to more chronic effects on biological processes such as reduced larval survival and recruitment, settlement, feeding efficiency and growth (Airoldi, 2003; Fabricius, 2005; Cheung and Shin, 2005; Lohrer et al., 2006; Walker, 2007). High SSCs in the water column can be particularly detrimental to benthic suspension feeders and may lead to clogging of their filtering apparatus, thus affecting growth, reproduction and other physiological processes (Ellis et al., 2002; Hewitt and Norkko, 2007).

Sponges (Phylum Porifera) are an important and diverse suspension feeding group (Wilkinson and Evans, 1989; Bell and Barnes, 2000; Murillo et al., 2012) that have a number of important functional roles in benthic systems (Bell, 2008; Maldonado et al., 2017). In temperate regions, sponges can process large volumes of water and efficiently retain particulate and dissolved organic matter (Perea-Blazquez et al., 2012). While some sponge species can be found and even thrive in areas of high settled and suspended sediment (e.g. Bell and Barnes, 2000; Knapp et al.,

\footnotetext{
* Corresponding author.

E-mail address: vonda.cummings@niwa.co.nz (V.J. Cummings).
} 
2013), there is strong evidence, primarily from tropical species, that sediment is generally detrimental to sponges (Bell et al., 2015; but see Schonberg, 2016), and that their diversity and abundance is lower in high sediment environments (Leys et al., 2004; Bannister et al., 2012; Stubler et al., 2015).

Exposure to suspended sediments has been reported to clog the aquiferous system and to reduce or arrest water pumping in several sponge species (Gerrodette and Flechsig, 1979; Leys et al., 1999; Tompkins-MacDonald and Leys, 2008; Bannister et al., 2012; Strehlow et al., 2016; Grant et al., 2018). As pumping is required for feeding and respiration, clogging induced by fine sediments can alter particle retention (Lohrer et al., 2006) and oxygen consumption rates (Gerrodette \& Fleshing, 1979). Despite these reported impacts on pumping however, respiration rates in sponges exposed to suspended sediments have shown contrasting results: increasing in some studies (Bannister et al., 2012; McGrath et al., 2017) and decreasing in others (Lohrer et al., 2006; Tjensvoll et al., 2013; Kutti et al., 2015; Pineda et al., 2017). Increased respiration rates may result from the sponges employing mechanisms to remove sediment from their aquiferous system, such as mucus production (see Biggerstaff et al., 2017; McGrath et al., 2017), while reduced respiration rates may result from a reduction in water pumping rates. A protracted reduction in sponge pumping has been correlated with reduced growth and reproduction, and lower survival (Roberts et al., 2006; Whalan et al., 2007; Maldonado et al., 2008). These contrasting results highlight the difficulty in making generalisations about impacts of sediment on sponges, and the need for location-specific and taxon-specific studies to understand suspended sediment impacts and determine SSC tolerance thresholds (e.g. Scanes et al., 2018).

In New Zealand, elevated sediment loads in coastal areas are recognized as a major threat to coastal biodiversity (Schwarz et al., 2006; Ministry for the Environment, 2015; Cussioli et al., 2019; Siciliano et al., 2019). Land-based activities such as agriculture, forestry, and urban development may have detrimental impacts on New Zealand's coastal marine environment through increased export of terrestrial sediments and their subsequent resuspension by coastal waves and currents (Thrush et al., 2004; Schwarz et al., 2006). Changes in rainfall patterns as a result of climate change, including increases in the magnitude and frequency of storm events (Reisinger et al., 2014; Law et al., 2018), are likely to result in more frequent input of sediments to coastal regions. Additionally, larger and more frequent storms will also result in greater and more frequent resuspension of coastal seafloor sediments (e.g. Orpin and Ridd, 2012). Activities such as dredging and trawling are common around New Zealand, and known to resuspend sediments, which can persist in the water column for considerable time, and can thus influence widespread areas (Ellis et al., 2017).

Sponges are one of largest contributors to total biomass in many shallow water regions of New Zealand (Shears et al., 2007), particularly on rocky subtidal reefs (Kelly et al., 2009; Berman and Bell, 2010). To date, few studies have addressed the impacts of resuspended benthic sediments on New Zealand sponges (Murray, 2009), although comprehensive studies of impacts of terrestrial sediments (with predominantly silt/clay particles and very low acidity) have been conducted (Lohrer et al., 2006; Schwarz et al., 2006). There is need for more information to define environmentally relevant suspended sediment tolerance thresholds for sponges and to assess how they might respond to any future changes in SSCs, which in turn can influence how such impacts can be managed. In this study, we assess how the common shallow water and widely distributed New Zealand cushion sponge Crella incrustans (Carter, 1885) (Class: Demospongiae, Family: Crellidae) might respond to exposure to a range of elevated SSCs that could be encountered in the wild, and investigate whether there are thresholds of SSC beyond which normal functioning might become compromised.

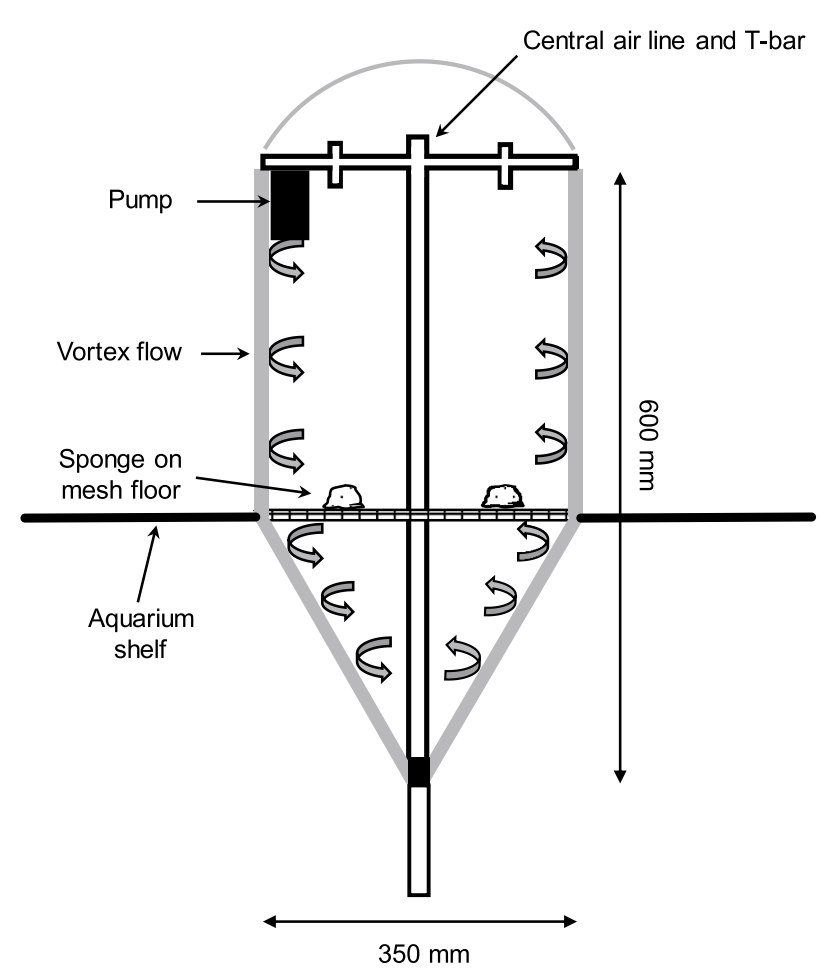

Fig. 1. Schematic of an experimental chamber (28 L), showing details of the mechanisms used to keep sediments in suspension.

\section{Material and methods}

\subsection{Sponge collection and preparation}

The cushion sponge $C$. incrustans was used for this experiment. Multiple sponges, ranging in size from 5 to $15 \mathrm{~cm}$ in diameter, were collected from 4 to $9 \mathrm{~m}$ depth in Breaker Bay, Wellington, New Zealand, by SCUBA divers. The sponges were immediately transferred to flow through holding tanks in NIWA Wellington's Marine Environmental Manipulation Facility (MEMF), with seawater from the adjacent bay (filtered to $0.1 \mu \mathrm{m}$ ) at temperatures similar to those at the collection site (16 C). Any epibionts were removed from the sponge surfaces before they were carefully sectioned into $\sim 3 \quad 3 \mathrm{~cm}$ portions, and each portion was attached to a stainless steel mesh disc $(4.5 \mathrm{~cm}$ diameter) using polyester thread (after Bates and Bell, 2018). They were subsequently left undisturbed for two weeks to allow membranes to reform and sponges to recover before being photographed (Nikon D850) and distributed randomly amongst 16 experimental chambers (N 4 per chamber). The sponges were fed daily with Nannochloropsis microalgae (1-2 $\mu \mathrm{m}$ cell diameter; Nanno $3600^{\mathrm{TM}}$ Reed Mariculture, U.S.). Sponges were handled entirely underwater, from their collection and during all stages of the experiment, to prevent stress from exposure to air.

\subsection{Chambers}

Sixteen experimental chambers, each $28 \mathrm{~L}$ in volume and based on the Vortex resuspension tank design of Davies et al. (2009), were used to expose the experimental sponges to a range of SSCs. A vortex flow within the tanks was created by water being pumped into two vertical pipes using an aquarium pump (Eheim) positioned at the top of the tanks. A flow rate of $15 \mathrm{ml} \mathrm{s}^{1}$ was used to force the water through small jets to create a directional flow (Fig. 1) and keep the sediment in suspension. Water jets in the lower half of the tank helped to re-suspend any settling sediment. Additionally, any sediment falling out of suspension that accumulated on the base of the chamber was pulled upwards by suction 


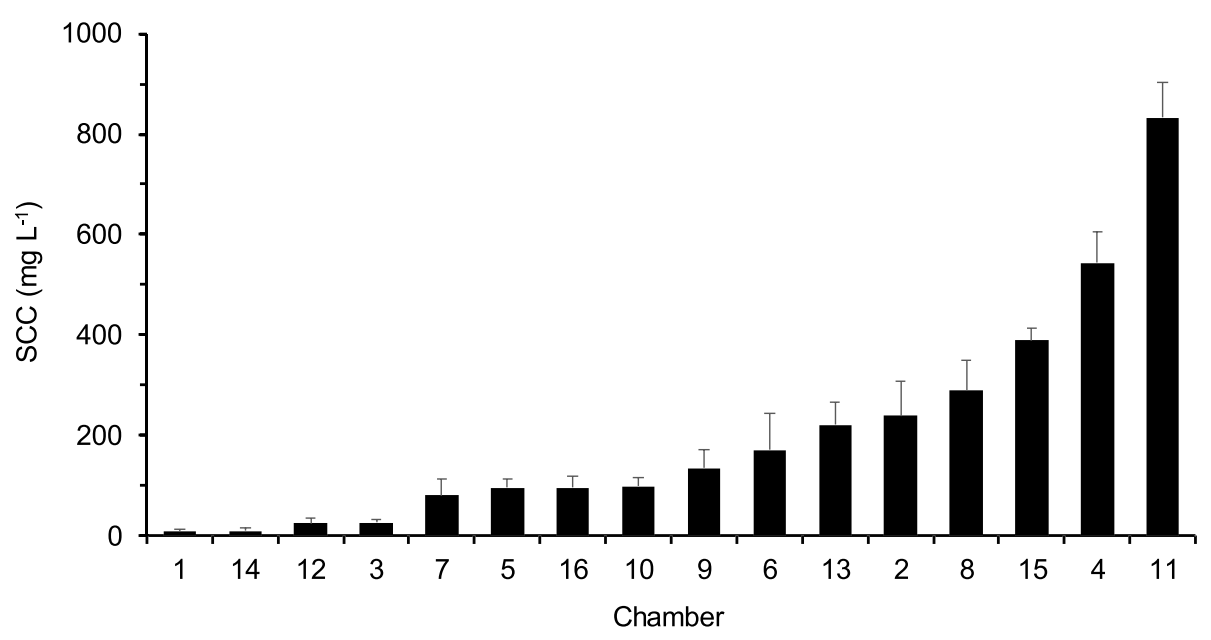

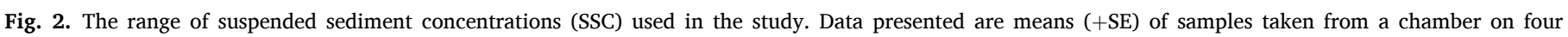
separate occasions.

generated with an airlift system and subsequently reintroduced to the chamber via two outlets on a $\mathrm{T}$ bar pipe at the top of the chamber (Fig. 1). Chambers were supplied with seawater at a rate of approximately $1 \mathrm{~L} \mathrm{~h}^{1}$, providing complete replacement of seawater in each tank daily. A $58 \mathrm{~cm}$ long outflow pipe increased the opportunity for any sediments within the outflow water to fall out of suspension (due to no vortex and low flow) within this outflow pipe. A $5 \quad 5 \mathrm{~cm}$ square of polyester fibre placed in the outflow pipe also prevented sediments from leaving the system. This filter was cleared twice daily and any captured sediments reintroduced to the chamber.

\subsection{Sediment treatments}

The sponges were exposed to a gradient of suspended sediment concentrations (SSCs), ranging from a control (no added sediment) to a maximum of $\sim 832 \mathrm{mg} \mathrm{L}^{1}$ (Fig. 2). Fig. 2 shows average SSC in each chamber ( $\mathrm{SE}$ ), determined from water samples collected weekly over 30 days. Water samples were filtered on a pre-dried and -weighed GF/F filter, before being dried at $60 \mathrm{C}$ for $16 \mathrm{~h}$.

This gradient design experiment was used in preference to a factorial design as we anticipated being able to generate response curves or to identify thresholds in the responses to SSC, and because similarly designed studies have demonstrated non-linear responses (e.g. Ellis et al., 2002; Hewitt and Norkko, 2007). SSC levels were chosen to encompass measured and modelled concentrations for coastal areas where these sponges are found (ranging from $\sim 10 \mathrm{mg} \mathrm{L}^{1}$ to $200 \mathrm{mg}$ $\mathrm{L}^{1}$; M. Hadfield NIWA, pers. comm.), storm generated resuspension of bottom sediments, high SSCs generated via runoff from forestry roads during storms (e.g. $1000 \mathrm{mg} \mathrm{L}^{1}$ in the Marlborough Sounds; Fahey and Coker, 1992), and to incorporate levels used in other studies (Kutti et al., 2015; Tjensvoll et al., 2013). Target SSCs were maintained for four weeks, after which time the chambers were cleaned of sediments and supplied with ambient seawater only for another two weeks to allow a 'recovery period'.

\subsubsection{SSC manipulation}

The SSCs were obtained by adding a slurry of sediment (particle size range from 3 to $125 \mu \mathrm{m}$; mean diam. $54 \mu \mathrm{m}$ ) to each chamber. The sediment had been sourced from a nearby inlet and defaunated by freezing, then thawed and dried at $110 \mathrm{C}$ for $24 \mathrm{~h}$. To ensure that target concentrations were maintained, chamber SSCs were monitored twice daily using a hand-held optical turbidity meter (Seapoint Turbidity meter) connected to a multimeter which displayed $\mathrm{mV}$. The relationship between $\mathrm{mV}$ and SSC had previously been determined for a broad range of concentrations of the specific sediment used in this study (Supplementary Fig. 1). If required, more sediment was added to the chambers after each monitoring check, with the quantity of sediment required determined by the difference between target $\mathrm{mV}$ and actual $\mathrm{mV}$ within the chamber, using the calibration curve (Supplementary Fig. 2). The weekly water samples referred to above were collected immediately prior to $\mathrm{mV}$ readings being taken for SSC monitoring. These provided additional confirmation of the relationship between SSC and $\mathrm{mV}$ determined during the pre-experimental calibration curve generation, and that it was maintained during the experiment.

The particle size distribution of the sediment suspended in the water column (and thus, to which the sponges were actually exposed) was determined from water samples (each $30 \mathrm{ml}$ ) in five of the highest SSC chambers (SSC 135, 221, 288, 389, 544 and $832 \mathrm{mg} \mathrm{L}^{1}$ ). Water samples were collected adjacent to the sponges in the chambers, on Days 5 and 29, (near the beginning and end, respectively, of the elevated SSC portion of the experiment). Samples were analysed for particle size using a Beckman Coulter LS 13-320 Dual Wavelength Laser Particle Sizer, covering a size range from 0.4 to $2000 \mu \mathrm{m}$ and displayed as volume percent across 92 discrete size classes. Granulometric analyses were carried out in Excel using GRADISTAT version 8.0 (Blott, 2010), which calculates the standard granulometric statistics, textural descriptions and size fraction percentages. This showed that the particles in suspension were $\sim 47 \%$ silt and $\sim 43 \%$ very fine sand, and that this distribution did not change over time (Supplementary Fig. 2).

\subsection{Evaluating sponge responses}

Sponge responses to the SSC treatments were assessed at different time points during the experiment: after 8, 23 and 30 days of suspended sediment (SS) exposure ( $\sim 1,3$ and 4 weeks, respectively; hereafter Day 8, Day 23, and Day 30), and after two weeks without SS ( $\sim 6$ weeks after addition to the chambers; hereafter Day 44). At each time point, a single sponge from each chamber was sacrificed to measure respiration rates, assess morphological changes, and to evaluate the degree to which the sediments had infiltrated the animal. The exception was Day 44, when only 14 chambers contained live sponges.

\subsubsection{Respiration rates}

Oxygen consumption rates were assessed at each sampling time point in sealed $75 \mathrm{ml}$ cylindrical Perspex respiration chambers with precalibrated PreSens oxygen sensor spots attached to their inner surface. The sealed respiration chambers were placed in a flow-through water bath to maintain constant water temperature, and the water was gently 
A.

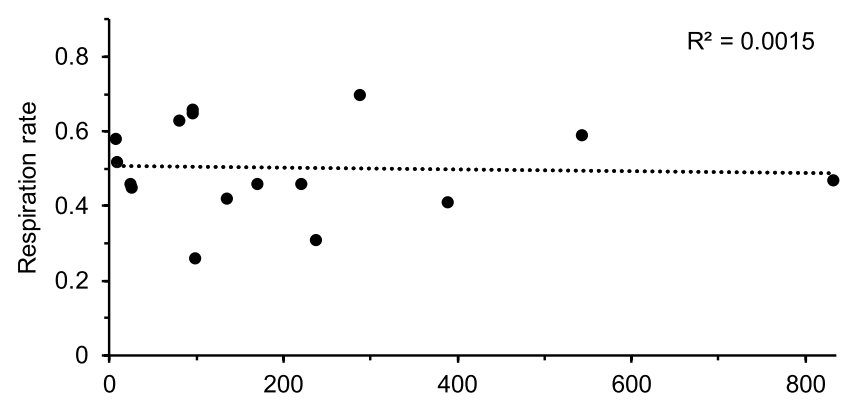

C.

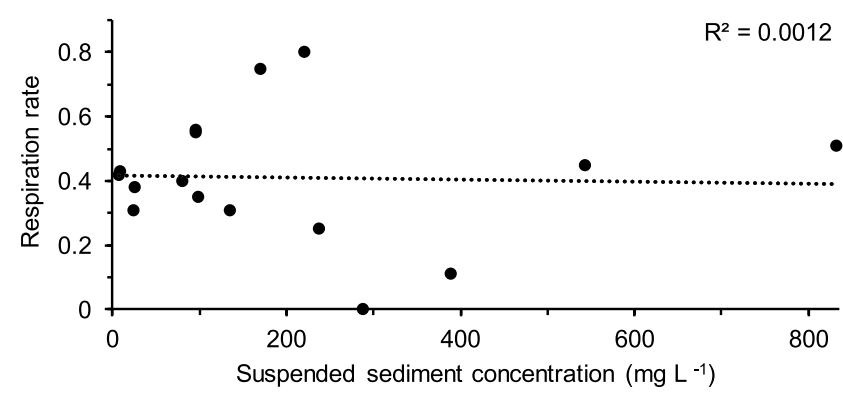

B.

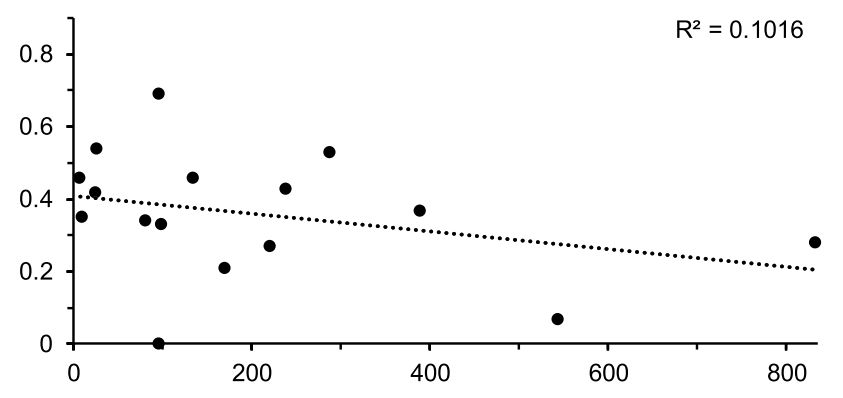

D.

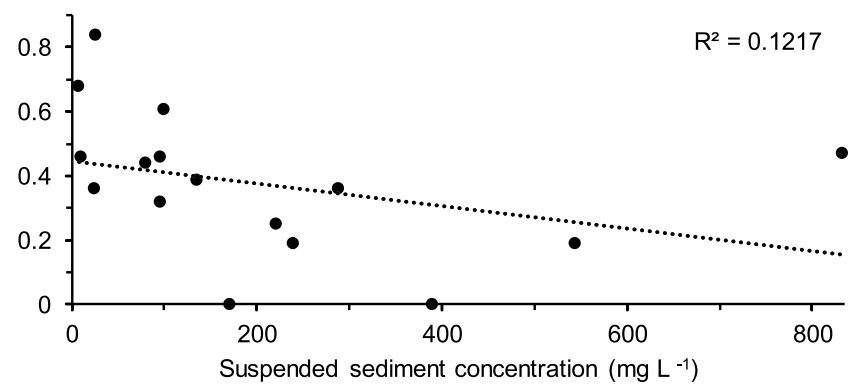

Fig. 3. Respiration rates of Crella incrustans ( $\mathrm{mg} \mathrm{O}_{2} \mathrm{~L}^{1} \mathrm{~g}{ }^{1}$ AFDW h ${ }^{1}$ ) recovered from each chamber after (A) 8 days, (B) 23 days, and (C) 30 days exposure to elevated SSCs. (D) shows rates on Day 44, following a two week recovery period in ambient seawater. Lines of best fit and $\mathrm{R}^{2}$ values for the relationship with SSC at each time point are shown.

stirred using a magnetic stir bar located in a separate compartment at the bottom of each chamber. Sponges were added to the respiration chambers and "dark-adapted" for 30 min to minimize the potential oxygen production by photosynthetic symbionts and to allow the sponge to recover from being moved into the chambers, before the chambers were sealed. The microbial community composition of $C$. incrustans has been previously described using 16S sequencing (Astudillo Garcia, 2017), with a small proportion (approx. 5\%) of cyanobacterial sequences being reported. However, earlier Pulse Amplitude Modulation (PAM) fluorometry work on C. incrustans (Bell unpublished data) found no evidence for photosynthetic activity (very low measurements of quantum yield (Y) of photosystem II). Dark respiration measurements were used a precaution, although it is unlikely these symbionts contribute significantly to the nutrition of $C$. incrustans.

Dissolved Oxygen (DO) readings were taken immediately after sealing and 30 min later using an optical fiber system (FIBOX 4, PreSenseGmbH, Germany). This time period was based on preliminary trials, to ensure oxygen levels did not drop below 75\%. Blank incubations ( $\mathrm{N} \quad 4$ ) containing only seawater were used to correct for any microbial community respiration in the seawater. Respiration rates $(\mathrm{mg}$ $\mathrm{O}_{2} \mathrm{~L}^{1} \mathrm{~g}^{1}$ AFDW h ${ }^{1}$ ) were determined after adjusting for the volume of water in the chamber and the sponge ash free dry weight (AFDW; after drying for $48 \mathrm{~h}$ at $60 \mathrm{C}$ to determine dry weight, followed by ashing at $500 \mathrm{C}$ for $5 \mathrm{~h}$ ).

\subsubsection{Morphology}

Photographs were taken of all sponges immediately prior to the experiment start (Day 0), and of each sponge on the day it was removed from the chamber (Day 8, Day 23 or Day 44), using a Nikon D850 camera. Comparisons between Day 0 and later images enabled us to assess changes in the appearance of each sponge during the experiment. Each sponge was then sectioned (transversely) and photographs were taken of the internal surfaces. A scale and colour bar were included in each image, and analyses were conducted using ImageJ.
During the experiment some sponges grew projections on their dorsal surfaces, which we have termed "fistules". These irregular shaped growths were often observed growing through layers of sediment that had accumulated on the sponge surface. The number of fistules on each sponge was quantified using the images, and is presented as a portion of the sponge surface area (fistules $\mathrm{cm}^{2}$ ).

\subsection{Statistical analysis}

Plots were generated of respiration rate and number of fistules vs SSC, along with lines of best fit and $\mathrm{R}^{2}$ values. The effect of SSC on each response variable was assessed using two-way ANOVA with interactions (SSC, Day, SSC x Day), after first confirming that assumptions of normality and homogeneity of variance were met (by examining the residual distribution plots and residuals vs predicted values and quantiles and using the Shapiro-Wilk test for normality). Any sponges that had died were excluded from the analyses. Analyses were conducted using SAS Version 9.4 (SAS Institute).

\section{Results}

\subsection{Survival}

There were four deaths across all of the SSC treatments during the six week experiment, three on Day 23 (from chambers with SSC levels of 96, 170 and $389 \mathrm{mg} \mathrm{L}^{1}$ ), and one on Day 30 (in the $288 \mathrm{mg} \mathrm{L}^{1} \mathrm{SSC}$ chamber). The two dead sponges from the 96 and $389 \mathrm{mg} \mathrm{L}^{1}$ SSCs on Day 23 had originated from the same clone, so it is possible they were compromised during the pre-experiment sectioning, or that this sponge was unhealthy at the onset of the experiment.

\subsection{Respiration rates}

Respiration rates were variable between sponges $\left(0.1-0.8 \mathrm{mg} \mathrm{O}_{2} \mathrm{~L}^{1}\right.$ 
Table 1

Results of statistical tests investigating the influence of elevated SSC on Crella incrustans (A) respiration rates and (B) number of fistules. DF degrees of freedom, SS sum of squares, MS mean square.

\begin{tabular}{lccccc}
\hline \multicolumn{1}{c}{ DF } & SS & MS & F-value & Pr $>$ F \\
\hline A. Respiration rates $\left(\mathrm{mg} \mathrm{O}_{2} \mathrm{~L}^{1}{ }^{1} \mathrm{~g}^{1}{ }^{1} \mathrm{AFDW} \mathrm{h}^{1}{ }^{1}\right.$ ) & & \\
\hline Model & 7 & 0.236 & 0.034 & 1.34 & 0.2516 \\
Error & 52 & 1.311 & 0.025 & & \\
Corrected total & 59 & 1.548 & & & \\
SSC & 1 & 0.064 & 0.064 & 2.53 & 0.1178 \\
Day & 3 & 0.027 & 0.009 & 0.35 & 0.7881 \\
SSC x Day & 3 & 0.063 & 0.021 & 0.83 & 0.4808 \\
\hline B. Number of fistules $\left(\mathrm{cm}^{2}{ }^{2}\right)$ & & & & \\
\hline Model & 7 & 22.328 & 3.190 & 2.87 & 0.0130 \\
Error & 52 & 57.734 & 1.110 & & \\
Corrected total & 59 & 80.063 & & & \\
SSC & 1 & 8.622 & 8.622 & 7.77 & 0.0074 \\
Day & 3 & 2.651 & 0.883 & 0.80 & 0.5017 \\
SSC x Day & 3 & 3.260 & 1.087 & 0.98 & 0.4099 \\
\hline
\end{tabular}

$\mathrm{g}^{1}$ AFDWh ${ }^{1}$; Fig. 3). There was a slight negative relationship between respiration rate and SSC, which was strongest on Day $23\left(\mathrm{R}^{2} \quad 0.1016\right.$; Fig. 3B) and at the end of the two week recovery period in ambient seawater (Day $44 \mathrm{R}^{2} \quad$ 0.1217; Fig. 3D). This relationship was not detected as statistically significant using two way ANOVA (SSC F 1,52 2.53, p 0.1178; Table 1A).

\subsection{Morphology}

The appearance of fistules was noted over the course of the experiment (Figs. 4 and 5). The control sponges had $<1$ fistule $\mathrm{cm}^{2}$ on all sampling dates (Fig. 4). In all other treatments fistule numbers increased after Day 8. There was a positive relationship between fistule abundance and SSC which was strongest on Days 23 and 44 (Fig. 4). This relationship was statistically significant across all sampling Days (SSC $\mathrm{F}_{1,52}$ 7.77, p 0.0074; Table 1B).

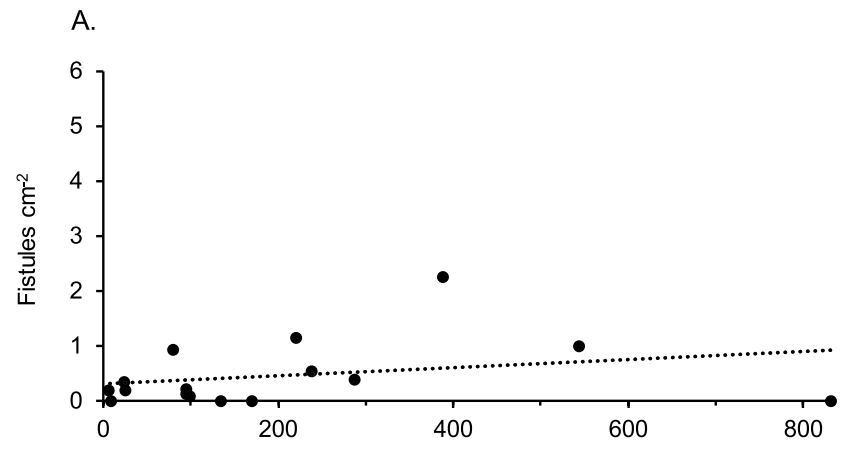

$$
\text { C. }
$$

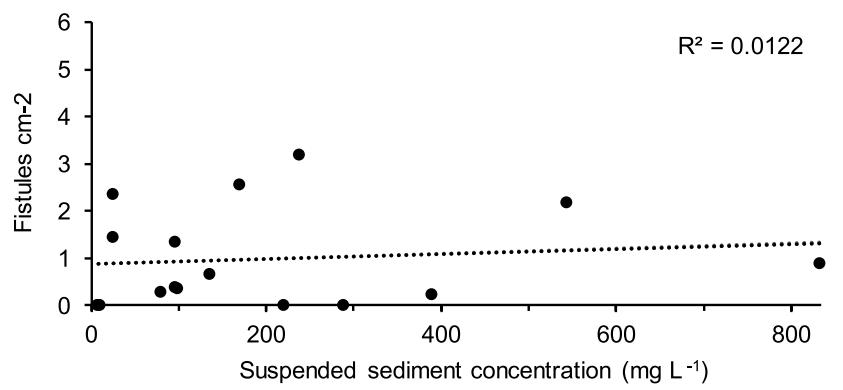

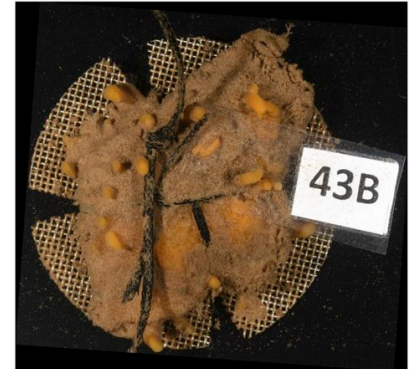

Fig. 5. An image of the surface of a sponge after 30 days exposure to SSC of $170 \mathrm{mg} \mathrm{L}^{1}$, showing fistules protruding from sediment that had settled on the sponge surface.

Dissections revealed internal sediment accumulation in many sponges (Fig. 6; Supplementary data). Qualitative visual assessments showed internal sediment build up even after only eight days exposure (Fig. 6). On this sampling date about half of the sponges in the elevated SSC chambers contained sediments, including those from the four highest levels. On Days 23 and 30, sediments were apparent in all sponges exposed to elevated SSCs, with one exception ( $99 \mathrm{mg} \mathrm{L}{ }^{1} \mathrm{SSC}$ on Day 30 ). No sediment was observed in control sponges. The magnitude of this sediment incursion was variable, regardless of SCC treatment (Fig. 6). At the Day 44 time point, after two weeks in ambient seawater, two thirds of sponges still contained sediments; those that were 'sediment free' included sponges from the two lowest SSCs, and one each from the 96 and $221 \mathrm{mg} \mathrm{L}^{1}$ SSC chambers.

\section{Discussion}

This study has provided new information on the effect of elevated SSC on a common and widely distributed coastal New Zealand sponge, C. incrustans. Survival was high during the four week-long exposure to elevated SSCs, even at the highest concentration $\left(832 \mathrm{mg} \mathrm{L}^{1}\right)$. There

B.

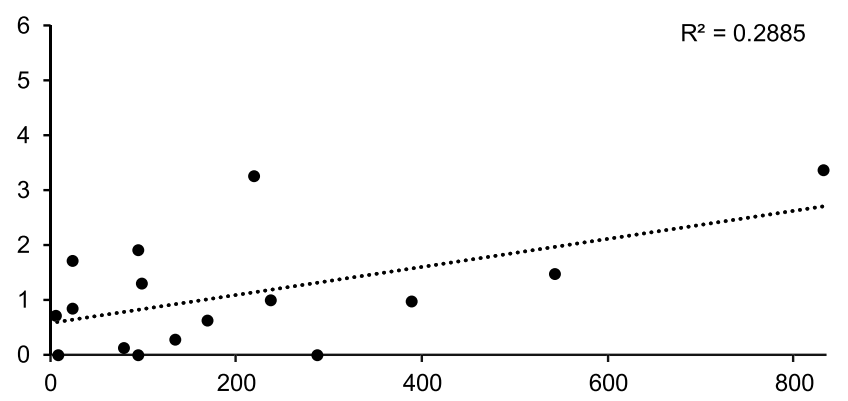

D.

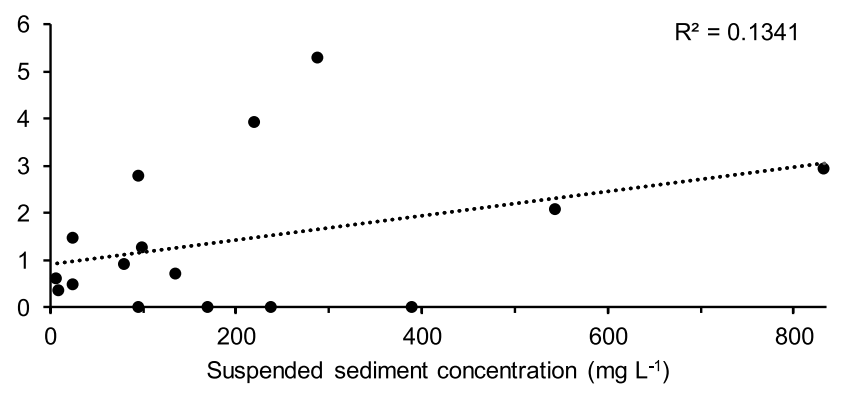

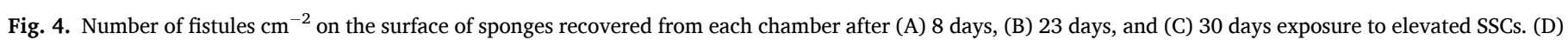

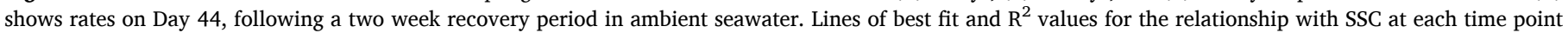
are shown. 


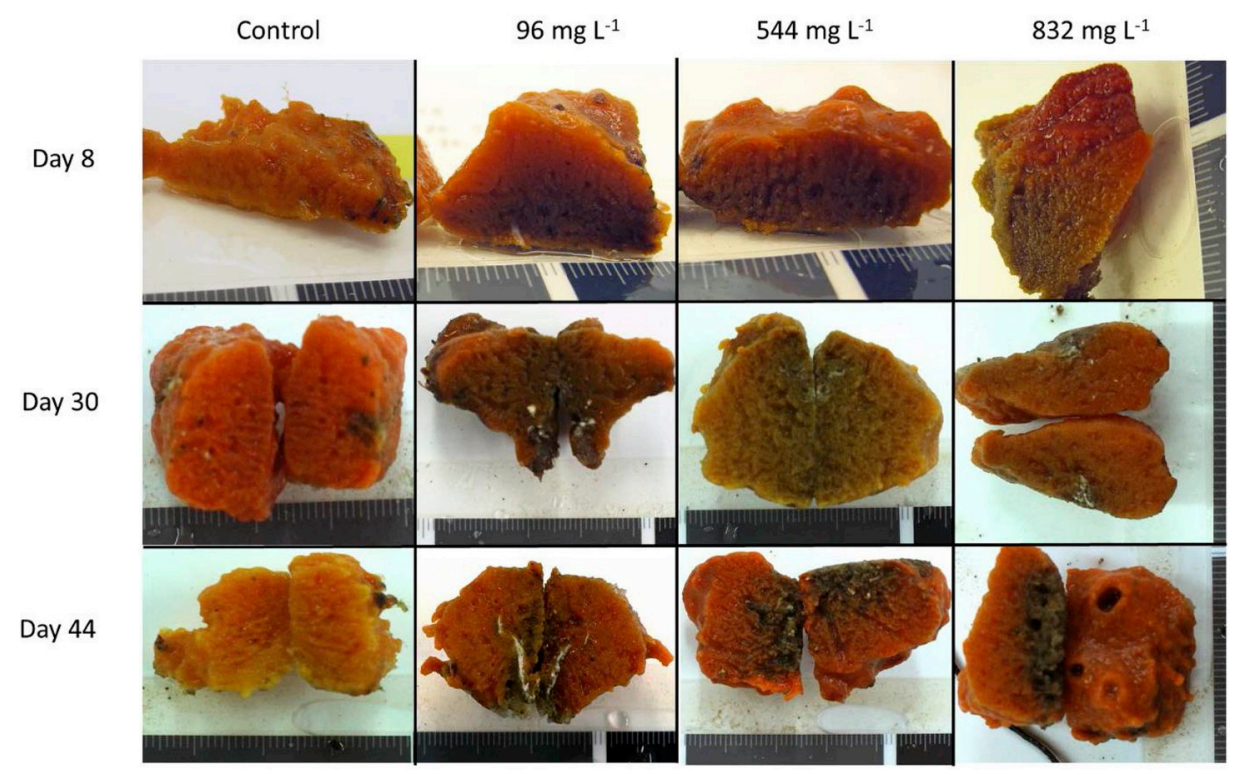

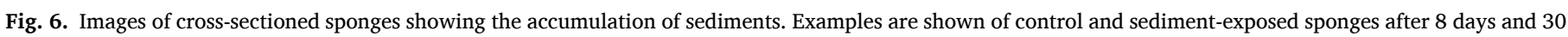
days, and at 44 days.

was considerable variation in responses amongst sponges, and no strong negative effects were detected, even at the highest SSCs.

\subsection{Respiration}

There was no significant effect of increased SSC on sponge respiration rates. It is possible that the duration of our experiment was not long enough to detect strong effects. However, many previous studies have reported significant effects of elevated SSCs on sponge respiration from much shorter exposure periods (Tjensvoll et al., 2013; Kutti et al., 2015). There are contrasting and variable reports of the effects of SSCs on sponge respiration and also pumping rates. Some experimental studies have reported increases in respiration and pumping rates in response to increased SSCs (Bannister et al., 2012; McGrath et al., 2017; Pineda et al., 2017), while others have shown decreases (Kutti et al., 2015; Pineda et al., 2017). In addition, in situ reductions in pumping rates have been reported in response to storm generated turbidity for some tropical sponge species (Reiswig, 1971). Several authors have linked increased respiration rates to energetically costly mucus production as a sediment tolerance mechanism/response (see Biggerstaff et al., 2017; McGrath et al., 2017), while decreased respiration rates have been linked to reduction or arrest in pumping in order to prevent sediment entering the sponge (Grant et al., 2018). Mucus production by C. incrustans was not measured (or observed) during our experiment. In contrast, we found no strong effect of elevated SSC on C. incrustans respiration rates, a result that is consistent with a recent study by Grant et al. (2019) who noted no change in pumping rates in one glass sponge species.

The lack of effects on respiration in our study is surprising, since the sponges were clearly accumulating sediment internally, which might be expected to compromise sponge pumping efficiency. C. incrustans appears to have limited loss of metabolic function in response to the SSCs we tested. Unfortunately, it is not possible to directly compare the actual respiration rates from our study with those of the other studies on sponge sediment impacts because of differences in the way respiration rates are standardized between studies. However, Bates et al. (2018) examined the effects of different $\mathrm{pH}$ treatments on $C$. incrustans and found similar respiration rates for their control sponges as we report in the present study (assuming an AFDW to DW ratio of 50-65\%), which provides further support for the limited effect of elevated SSCs on the respiration rate of our study species.

\subsection{Morphology}

Fistules were noted in many $C$. incrustans over the experiment, with their numbers positively correlated with SSC. Sponges living in soft sediment environments often have apical fistular structures that protrude upwards, ensuring some of the sponge is elevated above the sediment (Schonberg, 2016 and references therein). These elevated structures have been reported to be where the water is inhaled into the sponge (see Rützler, 1997). While fistules have been reported for many sponge species living in sediments and also for some hard substratum species (e.g. Polymastia spp. at Lough Hyne; Bell pers. obs.), to our knowledge this is the first report of such structures being produced during a sediment experiment. The production of fistules in C. incrustans was unexpected, as these have not been observed for this species at their field collection site (Bell pers. obs.). The generation of fistules in our experiment may be a natural adaptation strategy in response to sediment that had settled on the sponge surface rather than to increased SSC. This morphological change could potentially be the result of remodeling of the sponge body plan to move the inhalant pores to a higher position than the main sponge surface, enabling it to continue to pump water. Alternatively, the build up of sediment internally may have promoted fistule production. Further examination of these structures is required to determine whether these hypotheses are correct.

Our qualitative observations of accumulated internal sediment in C. incrustans suggest it may take longer than two weeks for sediment removal, with several sponges showing internal sediments after two weeks' recovery. A similar, variable response was noted for Ianthella basta after two weeks in control conditions, although internal sediment had decreased to a very low level (Strehlow et al., 2017). Some sponges are known to take up and incorporate sediments into their body and in some species, incorporation of sediment in their tissues is beneficial and can actually enhance growth and provide structural support (Schonberg, 2016, and references therein). However, previous experiments and taxonomic work with $C$. incrustans (Berman and Bell, 2010) have not noted any internal sediment in specimens from the field.

\subsection{Tolerance of coastal temperate sponges to sediment}

The SSC concentrations we used are high compared to those used in most previous experiments on sponges (see Bell et al., 2015; Schonberg, 2016) and likely represent conditions expected under major seafloor 
disturbance (e.g. extreme storms, mining or trawling; De Madron et al., 2005; Bradshaw et al., 2012). Despite this, we found no strong evidence for negative impacts of elevated SSC on C. incrustans, nor did the thin film of sediment that settled on the surface of the sponge appear to have detrimental effects. These results, combined with those of Bell (2004) from Ireland, and reports of dense sponge assemblages in other temperate regions that experience high SSCs and settled sediment (see Bell and Barnes, 2000), support the view that shallow temperate sponges may be able to tolerate high levels of suspended sediment, and that sensitivity of sponge species to SSC is likely influenced by pre-adaptation to the turbidity of the natural habitat (e.g. Abdul Wahab et al., 2017; Grant et al., 2019). However, the properties of the disturbed sediment are also important, as shown by the detrimental effects of terrestrial sediments (with predominantly clay-silt particle size composition and very low pH) on Aoptos spp. (Lohrer et al., 2006) and Tethya burtoni (Schwarz et al., 2006).

\section{Conclusions}

Elevated SSCs do not appear to have strong effects on the physiology of the common New Zealand cushion sponge $C$. incrustans, at least over the time frame of this experiment. There were morphological changes, with the development of apical fistules that may be an adaptation to the sediment settling on their external surfaces, or accumulating internally, during the experiment. Sediment was taken up by $C$. incrustans, but the species has mechanisms to clear the sediment once the source of SSC is removed. We conclude that the coastal environments that these sponges live in may predispose them to coping with high SSCs, and that they may also be tolerant of sediment deposition events that temporarily cover their surfaces.

\section{Declaration of competing Interest}

The authors declare that they have no known competing financial interests or personal relationships that could have appeared to influence the work reported in this paper.

\section{CRediT authorship contribution statement}

Vonda J. Cummings: Conceptualization, Methodology, Formal analysis, Writing - original draft, Writing - review \& editing. Jennifer Beaumont: Conceptualization, Methodology, Formal analysis, Investigation, Writing - original draft, Writing - review \& editing. Valeria Mobilia: Conceptualization, Methodology, Investigation, Writing original draft, Writing - review \& editing. James J. Bell: Conceptualization, Methodology, Writing - original draft, Writing - review \& editing. Dianne Tracey: Conceptualization, Methodology, Writing - review \& editing. Malcolm R. Clark: Conceptualization, Writing - original draft, Writing - review \& editing. Neill Barr: Methodology, Investigation.

\section{Acknowledgements}

We thank Emily McGrath (Victoria University of Wellington, VUW), Graeme Moss, Ryan Evison (National Institute of Water and Atmospheric Research, Wellington, NIWA) for help with the set up and running of the experiment. VUW divers kindly collected the specimens, Peter Marriott (NIWA) advised on photography and image analysis, Mark Gall (NIWA) on SSC measurements, and Graeme Moss (NIWA) provided help in the laboratory. This research was conducted as part of the Sustainable Seas National Science Challenge, funded by the New Zealand Ministry of Business, Innovation and Employment (project SUSS17305), with support from VUW and NIWA. Valeria Mobilia was supported by a VUW Doctoral Scholarship.

\section{Appendix A. Supplementary data}

Supplementary data to this article can be found online at https://doi. org/10.1016/j.marenvres.2020.104886.

\section{References}

Abdul Wahab, M.A., Fromont, J., Gomez, O., Fisher, R., Jones, R., 2017. Comparisons of benthic filter feeder communities before and after a large-scale capital dredging program. Mar. Pollut. Bull. 122, 176-193.

Airoldi, L., 2003. The effects of sedimentation on rocky coast assemblages. Oceanogr. Mar. Biol. Annu. Rev. 41, 161-236.

Astudillo Garcia, M.D.C., 2017. Microbiology of Marine Sponges: from Community Structure to Symbiont Function. PhD thesis. The University of Auckland, New Zealand. http://hdl.handle.net/2292/36039.

Bannister, R.J., Battershill, C.N., De Nys, R., 2012. Suspended sediment grain size and mineralogy across the continental shelf of the Great Barrier Reef: impacts on the physiology of a coral reef sponge. Continent. Shelf Res. 32, 86-95.

Bates, T.E., Bell, J.J., 2018. Responses of two temperate sponge species to ocean acidification. N. Z. J. Mar. Freshw. Res. 52 (2), 247-263.

Bell, J.J., 2004. Evidence for morphology-induced sediment settlement prevention on the tubular sponge Haliclona urceolus. Mar. Biol. 146 (1), 29-38.

Bell, J.J., 2008. The functional roles of marine sponges. Estuar. Coast Shelf Sci. 79 (3), $341-353$.

Bell, J.J., Barnes, D.K., 2000. The distribution and prevalence of sponges in relation to environmental gradients within a temperate sea lough: inclined cliff surfaces. Divers. Distrib. 6 (6), 305-323.

Bell, J.J., McGrath, E., Biggerstaff, A., Bates, T., Bennett, H., Marlow, J., Shaffer, M., 2015. Sediment impacts on marine sponges. Mar. Pollut. Bull. 94 (1-2), 5-13.

Berman, J., Bell, J.J., 2010. Spatial variability of sponge assemblages on the Wellington south coast, New Zealand. Open Mar. Biol. J. 4, 12-25.

Biggerstaff, A., Smith, D.J., Jompa, J., Bell, J.J., 2017. Metabolic responses of a phototrophic sponge to sedimentation supports transitions to sponge-dominated reefs. Sci. Rep. 7 (1), 2725.

Blott, S.J., 2010. GRADISTAT Ver. 8.0: A Grain Size Distribution and Statistics Package for the Analysis of Unconsolidated Sediments by Sieving or Laser Granulometer. Kenneth Pye Associates Ltd, UK. www.kpal.co.uk/gradistat.html.

Bradshaw, C., Tjensvoll, I., Skold, M., Allan, I.J., Molvaer, J., Magnusson, J., Naes, K., Nilsson, H.C., 2012. Bottom trawling resuspends sediment and releases bioavailable contaminants in a polluted fjord. Environ. Pollut. 170, 232-241.

Capuzzo, J.M., Burt, W.V., Duedall, I.W., Park, P.K., Kester, D.R., 1985. The impact of waste disposal in nearshore environments. In: Ketchum, B.H., et al. (Eds.), Wastes in the Ocean. Volume 6. Nearshore Waste Disposal. John Wiley, New York, pp. 3-38.

Carballo, J.L., 2006. Effect of natural sedimentation on the structure of tropical rocky sponge assemblages. Ecoscience 13 (1), 119-130.

Cheung, S.G., Shin, P.K.S., 2005. Size effects of suspended particles on gill damage in green-lipped mussel Perna viridis. Mar. Pollut. Bull. 51, 801-810.

Crain, C.M., Halpern, B.S., Beck, M.W., Kappel, C.V., 2009. Understanding and managing human threats to the coastal marine environment. Ann. N. Y. Acad. Sci. 1162 (1), 39-62.

Cussioli, M.C., Bryan, K.R., Pilditch, C.A., de Lange, W.P., Bischof, K., 2019. Light penetration in a temperate meso-tidal lagoon: implications for seagrass growth and dredging in Tauranga Harbour, New Zealand. Ocean Coast Manag. 174, 25-37.

Davies, A.J., Last, K.S., Attard, K., Hendrick, V.J., 2009. Maintaining turbidity and current flow in laboratory aquarium studies, a case study using Sabellaria spinulosa. J. Exp. Mar. Biol. Ecol. 370 (1-2), 35-40.

De Madron, X.D., Ferre, B., Le Corre, G., Grenz, C., Conan, P., Pujo-Pay, M., Buscail, R., Bodiot, O., 2005. Trawling-induced resuspension and dispersal of muddy sediments and dissolved elements in the Gulf of Lion (NW Mediterranean). Continent. Shelf Res. 25 (19-20), 2387-2409.

Ellis, J.I., Clark, M.R., Rouse, H.L., Lamarche, G., 2017. Environmental management frameworks for offshore mining: the New Zealand approach. Mar. Pol. 84, 178-192.

Ellis, J., Cummings, V., Hewitt, S., Thrush, S., Norkko, A., 2002. Determining effects of suspended sediment on condition of a suspending feeding bivalve (Atrina zelandica): results of a survey, a laboratory experiment and a field transplant experiment. J. Exp. Mar. Biol. Ecol. 267, 147-174.

Erftemeijer, P.L., Riegl, B., Hoeksema, B.W., Todd, P.A., 2012. Environmental impacts of dredging and other sediment disturbances on corals: a review. Mar. Pollut. Bull. 64 (9), 1737-1765.

Fabricius, K.E., 2005. Effects of terrestrial runoff on the ecology of corals and coral reefs: review and synthesis. Mar. Pollut. Bull. 50 (2), 125-146.

Fahey, B.D., Coker, R.J., 1992. Sediment production from forest roads in Queen Charlotte forest and potential impact on marine water quality, Marlborough Sounds, New Zealand. N. Z. J. Mar. Freshw. Res. 26, 187-195.

Fisher, R., Stark, C., Ridd, P., Jones, R., 2015. Spatial patterns in water quality changes during dredging in tropical environments. PloS One 10 (12), e0143309.

Gerrodette, T., Flechsig, A.O., 1979. Sediment-induced reduction in the pumping rate of the tropical sponge Verongia lacunosa. Mar. Biol. 55 (2), 103-110.

Grant, N., Matveev, E., Kahn, A.S., Leys, S.P., 2018. Suspended sediment causes feeding current arrests in situ in the glass sponge Aphrocallistes vastus. Mar. Environ. Res. 137, 111-120.

Grant, N., Matveev, E., Kahn, A.S., Archer, S.K., Dunham, A., Bannister, R.J., EerkesMedrano, D., Leys, S.P., 2019. Effect of suspended sediments on the pumping rates of three species of glass sponge in situ. Mar. Ecol. Prog. Ser. 615, 79-100. 
Halpern, B.S., Frazier, M., Potapenko, J., Casey, K.S., Koenig, K., Longo, C., Lowndes, J. S., Rockwood, C.R., Selig, E.R., Selkoe, K.A., Walbridge, S., 2015. Spatial and temporal changes in cumulative human impacts on the world's ocean. Nat. Commun. 6, 7615 .

Hewitt, J.E., Norkko, J.T., 2007. Incorporating temporal variability of stressors into studies: an example using suspension-feeding bivalves and elevated suspended sediment concentrations. J. Exp. Mar. Biol. Ecol. 341, 131-141.

Jones, R., Fisher, R., Bessell-Browne, P., 2019. Sediment deposition and coral smothering. PloS One 14 (6), e0216248.

Kelly, M., Edwards, A.R., Wilkinson, M.R., Alvarez, B., Cook, S. de C., Bergquist, P.R., Buckeridge, J.S., Campbell, H.J., Reiswig, H.M., Valentine, C., Vacelet, J., 2009. Phylum Porifera - Sponges. New Zealand Inventory of Biodiversity, vol. 1. Canterbury University Press, pp. 23-46.

Knapp, I.S.S., Williams, G.J., Carballo, J.L., Cruz-Barraza, J.A., Gardner, J.P.A., Bell, J.J., 2013. Restriction of sponges to an atoll lagoon as a result of reduced environmental quality. Mar. Pollut. Bull. 66, 209-220.

Kutti, T., Bannister, R.J., Fosså, J.H., Krogness, C.M., Tjensvoll, I., Søvik, G., 2015. Metabolic responses of the deep-water sponge Geodia barretti to suspended bottom sediment, simulated mine tailings and drill cuttings. J. Exp. Mar. Biol. Ecol. 473, 64-72.

Larcombe, P., Ridd, P.V., Prytz, A., Wilson, B., 1995. Factors controlling suspended sediment on inner-shelf coral reefs, Townsville, Australia. Coral Reefs 14, 163-171.

Law, C.S., Rickard, G.J., Mikaloff-Fletcher, S.E., Pinkerton, M.H., Behrens, E., Chiswell, S. M., Currie, K., 2018. Climate change projections for the surface ocean around New Zealand. N. Z. J. Mar. Freshw. Res. https://doi.org/10.1080/ 00288330.2017 .1390772

Levin, L.A., Mengerink, K., Gjerde, K.M., Rowden, A.A., Van Dover, C.L., Clark, M.R., Ramirez-Llodra, E., Currie, B., Smith, C.R., Sato, K.N., Gallo, N., Sweetman, A.K., Lily, H., Armstrong, C.W., Brider, J., 2016. Defining "serious harm" to the marine environment in the context of deep-seabed mining. Mar. Pol. 74, 245-259.

Leys, S.P., Mackie, G.O., Meech, R.W., 1999. Impulse conduction in a sponge. J. Exp. Biol. 202 (9), 1139-1150.

Leys, S.P., Wilson, K., Holeton, C., Reiswig, H.M., Austin, W.C., Tunnicliffe, V., 2004. Patterns of glass sponge (Porifera, Hexactinellida) distribution in coastal waters of British Columbia, Canada. Mar. Ecol. Prog. Ser. 283, 133-149.

Lohrer, A.M., Hewitt, J.E., Thrush, S.F., 2006. Assessing far-field effects of terrigenous sediment loading in the coastal marine environment. Mar. Ecol. Prog. Ser. 315, 13-18.

Maldonado, M., Aguilar, R., Bannister, R.J., Bell, J.J., Conway, K.W., Dayton, P.K., Leys, S.P., 2017. Sponge grounds as key marine habitats: a synthetic review of types, structure, functional roles, and conservation concerns. In: Rossi, S., Bramanti, L., Gori, A., Orejas Saco del Valle, C. (Eds.), Marine Animal Forests, Volume 1: the Ecology of Benthic Biodiversity Hotspots, pp. 145-183.

Maldonado, M., Giraud, K., Carmona, C., 2008. Effects of sediment on the survival of asexually produced sponge recruits. Mar. Biol. 154 (4), 631-641.

McGrath, E.C., Smith, D.J., Jompa, J., Bell, J.J., 2017. Adaptive mechanisms and physiological effects of suspended and settled sediment on barrel sponges. J. Exp. Mar. Biol. Ecol. 496, 74-83.

Ministry for the Environment and Statistics New Zealand, 2015. New Zealand's environmental reporting series: Environment Aotearoa 2015. Available from: www. mfe.govt.nz.

Murillo, F.J., Muñoz, P.D., Cristobo, J., Ríos, P., Gonzalez, C., Kenchington, E., Serrano, A., 2012. Deep-sea sponge grounds of the Flemish Cap, Flemish Pass and the Grand Banks of Newfoundland (Northwest Atlantic Ocean): distribution and species composition. Mar. Biol. Res. 8 (9), 842-854.

Murray, H.J.R., 2009. Oxygen consumption rates of sponges and the effect of UV-B radiation and sediment. MSc thesis. Victoria University of Wellington, New Zealand.

Oebius, H.U., Becker, H.J., Rolinski, S., Jankowski, J.A., 2001. Parametrization and evaluation of marine environmental impacts produced by deep-sea manganese nodule mining. Deep-Sea Res. Part II 48, 3453-3467.

Orpin, A., Ridd, P., 2012. Exposure of inshore corals to suspended sediments due to wave-resuspension and river plumes in the central Great Barrier Reef: a reappraisal. Continent. Shelf Res. 47, 55-67.

Paradis, S., Masque, P., Puig, P., Juan-Diaz, X., Gorelli, G., Company, J.B., Palanques, A., 2018. Enhancement of sedimentation rates in the Foix Canyon after the renewal of trawling fleets in the early XXIst century. Deep-Sea Res. Part I 132, 51-59.

Perea-Blazquez, A., Davy, S.K., Bell, J.J., 2012. Estimates of particulate organic carbon flowing from the pelagic environment to the benthos through sponge assemblages. PloS One 7 (1), e29569. https://doi.org/10.1371/journal.pone.0029569.

Pineda, M.C., Strehlow, B., Sternel, M., Duckworth, A., Jones, R., Webster, N.S., 2017. Effects of suspended sediments on the sponge holobiont with implications for dredging management. Sci. Rep. 7 (1), 4925.
Reisinger, A., Kitching, R.L., Chiew, F., Hughes, L., et al., 2014. Australasia. In: Barros, V. R., Field, C.B., Dokken, D.J., Mastrandrea, M.D., Mach, K.J., Bilir, T.E.,

Chatterjee, M., Ebi, K.L., Estrada, Y.O., Genova, R.C., Girma, B., Kissel, E.S., Levy, A. N., MacCracken, S., Mastrandrea, P.R., White, L.L. (Eds.), Climate Change 2014: Impacts, Adaptation, and Vulnerability. Part B: Regional Aspects. Contribution of Working Group II to the Fifth Assessment Report of the Intergovernmental Panel on Climate Change. Cambridge University Press, Cambridge, United Kingdom and New York, NY, USA, pp. 1371-1438.

Reiswig, H., 1971. In situ pumping activities of tropical Demospongiae. Mar. Biol. 9, 38-50.

Roberts, J.M., Wheeler, A.J., Freiwald, A., 2006. Reefs of the deep: the biology and geology of cold-water coral ecosystems. Science 312 (5773), 543-547.

Rolinski, S., Segschneider, J., Sundermann, J., 2001. Long-term propagation of tailings from deep-sea mining under variable conditions by means of numerical simulations. Deep-Sea Research II 48, 3469-3485.

Rützler, K., 1997. The role of psammobiontic sponges in the reef community. In: Lessios, H.A., Macintyre, I.G. (Eds.), Proceedings of the Eighth International Cora Reef Symposium, Panama City, 24 - 29 June 1996, vol. 2. Smithsonian Tropical Research Institute, Balboa, pp. 1393-1398.

Scanes, E., Kutti, T., Fang, J.K.H., Johnston, E.L., Ross, P.M., Bannister, R.J., 2018. Mine waste and acute warming induce energetic stress in the deep-sea sponge Geodia atlantica and coral Primnoa resedeaformis; results from a mesocosm study. Front. Mar. Sci. 5, 129. https://doi.org/10.3389/fmars.2018.00129.

Schonberg, C.H.L., 2016. Happy relationships between marine sponges and sediments - a review and some observations from Australia. J. Mar. Biol. Assoc. U. K. 96 (2), 493-514.

Schwarz, A.M., Taylor, R., Hewitt, J., Philips, N., Shima, J., Cole, R., Budd, R., 2006. Impacts of terrestrial runoff on the biodiversity of rocky reefs. New Zealand Aquatic Environment and Biodiversity Report 7 (109), 1176-9440.

Shears, N.T., 2007. Biogeography, community structure and biological habitat types of subtidal reefs on the South Island West Coast, New Zealand. Sci. Conserv. 281, 53 p.

Siciliano, A., Schiel, D.R., Thomsen, M.S., 2019. Effects of local anthropogenic stressors on a habitat cascade in an estuarine seagrass system. Mar. Freshw. Res. 70, 1129-1142.

Storlazzi, C.D., Field, M.E., Bothner, M.H., Presto, M.K., Draut, A.E., 2009. Sedimentation processes in a coral reef embayment: Hanalei Bay, Kauai. Mar. Geol. 264, 140-151.

Strehlow, B.W., Jorgensen, D., Webster, N.S., Pineda, M.C., Duckworth, A., 2016. Using a thermistor flowmeter with attached video camera for monitoring sponge excurrent speed and oscular behaviour. PeerJ 4, 2761.

Strehlow, B.W., Pineda, M., Duckworth, A., Kendrick, G.A., Renton, M., Abdul Wahab, M. A., Webster, N.S., Clode, P.L., 2017. Sediment tolerance mechanisms identified in sponges using advanced imaging techniques. PeerJ 5, e3904. https://doi.org/ 10.7717/peerj.3904.

Stubler, A.D., Duckworth, A.R., Peterson, B.J., 2015. The effects of coastal development on sponge abundance, diversity, and community composition on Jamaican coral reefs. Mar. Pollut. Bull. 96, 261-270.

Syvitski, J.P.M., Vorosmarty, C.J., Kettner, A.J., Green, P., 2005. Impact of humans on the flux of terrestrial sediment to the global coastal ocean. Science 308, 376-380.

Thrush, S.F., Dayton, P.K., 2002. Disturbance to marine benthic habitats by trawling and dredging: implications for marine biodiversity. Annu. Rev. Ecol. Systemat. 33 (1), 449-473.

Thrush, S.F., Hewitt, J.E., Cummings, V.J., Ellis, J.I., Hatton, C., Lohrer, A., Norkko, A., 2004. Muddy waters: elevating sediment input to coastal and estuarine habitats. Front. Ecol. Environ. 2 (6), 299-306.

Tjensvoll, I., Kutti, T., Fosså, J.H., Bannister, R.J., 2013. Rapid respiratory responses of the deep-water sponge Geodia barretti exposed to suspended sediments. Aquat. Biol. 19 (1), 65-73.

Tompkins-MacDonald, G.J., Leys, S.P., 2008. Glass sponges arrest pumping in response to sediment: implications for physiology of the hexactinellid conduction system. Mar. Biol. 154, 973-984.

Walker, J.W., 2007. Effects of fine sediments on settlement and survival of the sea urchin Evechinus chloroticus in northeastern New Zealand. Mar. Ecol. Prog. Ser. 331, 109-118.

Whalan, S., Battershill, C., De Nys, R., 2007. Variability in reproductive output across a water quality gradient for a tropical marine sponge. Mar. Biol. 153, 163-169.

Wilkinson, C.R., Evans, E., 1989. Sponge distribution across Davies Reef, Great Barrier Reef, relative to location, depth, and water movement. Coral Reefs 8 (1), 1-7.

Wolanski, E., Fabricius, K., Spagnol, S., Brinkman, R., 2005. Fine sediment budget on an inner-shelf coral-fringed island, Great Barrier Reef of Australia. Estuar. Coast Shelf Sci. 65, 153-158. 


\title{
Short-term physiological responses of the New Zealand deep-sea sponge Ecionemia novaezealandiae to elevated concentrations of suspended sediments
}

\author{
Valeria Mobilia $^{\mathrm{a},{ }^{*}}$, Vonda J. Cummings ${ }^{\mathrm{b}}$, Malcolm R. Clark ${ }^{\mathrm{b}}$, Dianne Tracey ${ }^{\mathrm{b}}$, James J. Bell ${ }^{\mathrm{a}}$ \\ ${ }^{\text {a }}$ School of Biological Sciences, Victoria University of Wellington, Wellington 6140, New Zealand \\ ${ }^{\mathrm{b}}$ National Institute of Water and Atmospheric Research (NIWA), Wellington, New Zealand
}

\section{A R T I C L E I N F O}

\section{Keywords:}

Porifera

Seafloor

Respiration

Sedimentation

Disturbance

New Zealand

\begin{abstract}
A B S T R A C T
The generation of sediment plumes by human activities, such as bottom fishing and potential deep-sea mining, poses threats to deep-sea benthic fauna. Sponges are important components of deep-sea ecosystems and can be particularly sensitive to elevated suspended sediment concentrations. In this study, we exposed the deep-sea New Zealand sponge Ecionemia novaezealandiae (Dendy, 1924) (Demospongiae: Ancorinidae) to a range of suspended sediment concentrations (SSC) (32, 78 and $475 \mathrm{mg} \mathrm{l}^{-1}$ ) and control conditions (no added sediment) continuously for two weeks. Survival was high (97\%), with only one death (at the highest SSC). Half of the sponges in the 475 $\mathrm{mg}^{-1}$ treatment showed partial necrosis by the end of the two-week exposure. Respiration rates of sponges in the sediment addition treatments decreased relative to control sponges by 27,37 and $60 \%$, respectively, after day 1 ; and by 7,17 , and $27 \%$, respectively, after 14 days of suspended sediment exposure. At the end of the experiment, sectioning of the sponges revealed sediments deep in the tissue of all specimens, including controls, indicating previous incorporation of sediment occurred in their natural environment. Despite the high survival, the decreased respiration rates and partial necrosis with increasing SSC indicated a decline in sponge condition that could affect this species beyond the disturbance period.
\end{abstract}

\section{Introduction}

The deep-sea (here defined as below $200 \mathrm{~m}$ ) covers around $90 \%$ of the marine environment and is increasingly experiencing anthropogenic stressors as result of the exploitation of the biological and mineral resources it contains (Ramirez-Llodra et al., 2015; Mengerink et al., 2014). Offshore bottom fishing activities and industries focused on deep-sea regions, such as oil drilling, cable laying, and mineral exploration, have been increasing in recent decades (Glover and Smith, 2003; Ramirez-Llodra et al., 2015). Bottom-contact activities pose several threats to deep-sea ecosystems as they generally lead to removal of the substrate and associated fauna, and to modification of seabed morphology. Such anthropogenic disturbance can impact benthic communities and lead to habitat modification or, in some cases, complete habitat loss (e.g., see Clark et al., 2016; Levin et al., 2016). Some of these activities, particularly bottom fishing and proposed deep-sea mining, also have the potential to generate sediment plumes and deposits, which can lead to burial and smothering of fauna over larger areas (Hall-
Spencer et al., 2002; Boschen et al., 2016).

Bottom contact fishing gear and several types of potential deep-sea mining operations can create a disturbance that extends up to $10 \mathrm{~cm}$ into the seafloor, and can re-suspend bottom sediments into the water column. Suspended sediments may reach concentrations up to $500 \mathrm{mg}$ $1^{-1}$ and can form plumes that could extend over hundreds of kilometres depending on local hydrodynamic conditions (Schoellhamer, 1996; Durrieu de Madron et al., 2005; Bradshaw et al., 2012; Parsons et al., 2013). While larger sediment particles tend to settle quickly, fine particles can remain in suspension for days to weeks and be transported over hundreds of kilometres by currents (Rolinski et al., 2001; Lepland and Mortensen, 2008). Bottom contact fishing practises and deep-sea mining operations may, therefore, contribute substantially to sediment resuspension and transport in areas where natural sediment suspension is generally low (Ferré et al., 2008), potentially leading to severe and long-lasting effects on the associated benthic communities (Miller et al., 2002; Gollner et al., 2017), including sponges (e.g., Xavier et al., 2015; Pham et al., 2019).

\footnotetext{
* Corresponding author.

E-mail address: valeria.mobilia@vuw.ac.nz (V. Mobilia).
} 
Elevated suspended sediment levels in the water column can be particularly harmful to benthic suspension and filter feeders as it may clog their filtration system, altering respiration, feeding ability and, indirectly, growth and reproduction (Ellis et al., 2002; Hewitt and Norkko, 2007). Sponges are primarily suspension feeders that can dominate and provide key ecosystem services in some deep-sea benthic environments (e.g., lower shelf, bathyal and/or abyssal depths) (Murillo et al., 2012; Klitgaard and Tendal, 2004; Longo et al., 2005; Bell, 2008; Maldonado et al., 2017; Cathalot et al., 2015). In some areas, deep-sea sponges comprise up to $90 \%$ of the benthic biomass (Murillo et al., 2012; Klitgaard and Tendal, 2004). These high biomasses are responsible for significant nitrogen, carbon and silica cycling processes (Maldonado et al., 2005; Pile and Young, 2006; Chu et al., 2011; Kahn et al., 2015). Furthermore, deep-sea sponge gardens can, along with corals, provide structurally complex habitats that support high abundance and diversity of fish and invertebrates (Tracey et al., 2011; Clark and Dunn, 2012; Hourigan et al., 2017; Maldonado et al., 2017). Because of their vulnerability and importance for deep-sea ecosystems, these sponge habitats have been classified as Vulnerable Marine Ecosystems (VMEs) by the United Nations (FAO, 2009).

Although it has been estimated that $10 \%$ of all sponges are well adapted to life in areas with high levels of suspended and settled sediment (Schönberg, 2016), there is also evidence that sediment can be deleterious to many sponge species at the individual as well as at population levels (Bell et al., 2015). Sponges exposed to elevated concentrations of suspended sediment filter fine particles into their aquiferous system and choanocyte chambers (Tompkins-Mac Donald and Leys, 2008), which can result in clogging of their filtration apparatus. Suspended sediments can also induce a reduction in sponge pumping activity (Lohrer et al., 2006; Tompkins-Mac Donald and Leys, 2008; Strehlow et al., 2016; Grant et al., 2018, 2019), which can affect feeding efficiency (Lohrer et al., 2006), alter respiration rates (Bannister et al., 2012; Tjensvoll et al., 2013; Kutti et al., 2015; Pineda et al., 2017), cause tissue abrasion (Nava and Carballo, 2013), and possibly result in reduced survival (Maldonado et al., 2008). Studies investigating changes in respiration rates in sponges exposed to suspended sediment have shown contrasting results: some have shown increases (e.g. Bannister et al., 2012; McGrath et al., 2017), some have shown decreases (e. g. Lohrer et al., 2006; Tjensvoll et al., 2013; Kutti et al., 2015; Pineda et al., 2017), while other remained largely unaffected (e.g. Cummings et al., 2020; Wurz et al., 2021). The effects depend on both the sediment concentration and sediment properties (i.e. grain size and type; see Bannister et al., 2012; Kutti et al., 2015).

To date, most sedimentation impact studies have been on shallowwater species (e.g. Biggerstaff et al., 2017; McGrath et al., 2017; Pineda et al., 2017; Cummings et al., 2020), with only four deep-sea studies we are aware of globally, three of which are on sponges belonging to the genus Geodia (Tjensvoll et al., 2013; Kutti et al., 2015; Scanes et al., 2018) and one on Vazella pourtalesii (Wurz et al., 2021). However, sponges are common in the deep seas around New Zealand (Bowden et al., 2017), including areas that are subject to bottom trawl and longline fisheries (Fisheries New Zealand, 2020), as well as in certain regions of interest for seabed minerals (Ellis et al., 2017). In 2015, a marine consent application to mine phosphorite nodules on the Chatham Rise (north eastern New Zealand) was declined due to uncertainty about the nature and the extent of adverse effects on biological communities (including effects of suspended and settled sediment) (NZ EPA, 2015). Models investigating mining plume dispersion on the Chatham Rise predicted peak suspended sediment concentrations of $100 \mathrm{mg} \mathrm{l}^{-1}$ inside the potential mining areas ( $2 \mathrm{~km}$ wide and $5 \mathrm{~km}$ long) and $50 \mathrm{mg}^{-1}$ outside the potential mining areas (Deltares, 2014). In addition to the Chatham Rise being an important area for New Zealand fisheries (with almost 50\% of the total EEZ area trawled in waters shallower than $1000 \mathrm{~m}$; Black et al., 2013), there is a strong impetus to assess potential impacts of sediment on deep-sea species to help inform management of human activities.
The aim of this study was to assess the physiological response of the brain-shaped sponge Ecionemia novaezealandiae (Dendy, 1924), a species common on the Chatham Rise (Kelly and Sim-Smith, 2012), to shortterm (after one day, and after two weeks) exposure to suspended sediments. We investigated responses to suspended sediment concentrations relevant to potential deep-sea mining operations and bottom fishing activities on the Chatham Rise. This is the first such investigation of a deep-sea New Zealand sponge to these impacts.

\section{Materials and methods}

\subsection{Sponge collection and maintenance}

In June 2019, twenty E. novaezealandiae samples were collected by beam trawl at about $300 \mathrm{~m}$ depth on the Chatham Rise during a NIWA voyage of RV Tangaroa (Clark et al., 2019). Temperature was recorded in situ with a conductivity, temperature and depth (CTD) profiler ( $10{ }^{\circ} \mathrm{C}$ ). Sponges taken from the trawl codend were placed immediately into cooled seawater $\left(10^{\circ} \mathrm{C}\right)$ and gently shaken when submerged to remove any potential air bubbles that could block the aquiferous system (Osinga et al., 1999). According to Fosså and Nilsen (1996), many sponges would die after even a short exposure to air, if the air in their canals was not removed. E. novaezealandiae samples showed no visible signs of distress (mortality or necrosis) in the several weeks following collection, and they were respiring (as indicated by a drop in oxygen levels during measurements), indicating that the brief exposure to air during collection had not affected their health status. Sponges were then transferred to a flow-through on-board aquaria system with fresh $10{ }^{\circ} \mathrm{C}$ seawater (filtered to $1 \mathrm{~mm}$ ) and held in the dark. At the end of the voyage, circa $24 \mathrm{~h}$ after collection, sponges were transferred to the Marine Environmental Manipulation Facility at NIWA, Wellington. Here the sponges were kept in the dark, in flow-through holding tanks with fresh seawater (filtered to $0.1 \mu \mathrm{m}$, so that all the food was removed), and at temperatures similar to those at the collection site $\left(9.5\right.$ to $\left.10{ }^{\circ} \mathrm{C}\right)$. Any epibionts were removed from the sponge surfaces so not to affect their responses to the experimental treatments (i.e. respiration rates). Out of the 20 sponges collected, the 13 largest ones $(\sim 20 \times 20 \mathrm{~cm})$ were cut into smaller 'clones' $(\sim 5 \times 6 \mathrm{~cm})$ to ensure size comparability across treatments and to provide replicates, and each clone had more than one osculum. Smaller sponges $(n=7)$ were not cut into clones. Sponges were then left undisturbed for four weeks to stabilise and heal tissue damage from cutting before the experiment began. Recovery from cutting was confirmed after observing pinacoderm growth over the surface of the cut. This metric of post-cutting recovery assessment has also been used by Bennett et al. (2017), who also allowed four weeks of acclimation post-cloning. Sponges were fed every other day with Nannochloropsis microalgae (1-2 $\mu \mathrm{m}$ cell diameter; Nanno $3600^{\mathrm{TM}}$ Reed Mariculture, U. S.). Nanno $3600^{\mathrm{TM}}$ commercial food was chosen for its cell size compatibility with sponge diet, after ensuring, based on literature evidence, that deep-sea sponges feed on phytoplankton, both in situ and when sampled and maintained under laboratory conditions (e.g. see Yahel et al., 2006; Robertson et al., 2017). Immediately prior to the start of the experiment, all sponges were photographed, weighed (buoyant weight), and randomly distributed amongst 16 experimental aquaria (two per aquarium; described below), ensuring that clones originating from the same donor sponge were placed across different aquaria and treatments (i.e. clones were tracked).

\subsection{Sediment treatments}

Sponges were exposed to four different target concentrations of suspended sediment (SSCs): $0,50,100,500 \mathrm{mg}^{-1}$, with $n=4$ replicate experimental aquaria for each treatment. The SSCs were chosen to include those predicted from models investigating mine plume dispersion on the Chatham Rise (50-100 mg 1-1; Deltares, 2014) and empirically-derived concentrations of sediments re-suspended by 
bottom trawling (up to $500 \mathrm{mg} \mathrm{l}^{-1}$ ). Sponges were exposed to the target SSCs for a two-week period, mimicking bottom-contact fishing activities and potential deep-sea mining operating for short periods in this area.

\subsection{Sediment collection and manipulation}

Natural sediment samples were collected with a multicorer from the Chatham Rise. The top $5 \mathrm{~cm}$ of the sediment column were used for this experiment, as this surface layer is most likely to be disturbed and resuspended in the water column by bottom-contact fisheries and mining (Palanques et al., 2001). Sediments were frozen at $-20^{\circ} \mathrm{C}$ to kill any living fauna. Prior to use in the experiment, sediments were thawed and dried at $100{ }^{\circ} \mathrm{C}$ overnight, and sieved $(150 \mu \mathrm{m}$ mesh). Sediment samples were analysed with a Beckam Coulter LS 13-120 Dual Wavelength Laser Particle Sizer to determine particle size distribution. Sediments had a mean diameter of $50 \mu \mathrm{m}$, and were comprised of $\sim 68 \%$ of mud and $\sim 32 \%$ very fine sand (Fig. S1) (GRADISTAT version 8.0; Blott, 2010).

Target suspended sediment concentrations were obtained by manually adding a sediment slurry (dried sediment mixed with seawater) to each experimental aquarium. SSCs in the chambers were monitored twice daily using a hand-held turbidity meter (Seapoint Turbidity meter) connected to a multimeter which displayed $\mathrm{mV}$. The relationship between suspended sediment concentrations (SSCs) and optical turbidity $(\mathrm{mV})$ had been determined prior to the experiment for a large range of concentrations (Fig. S2). When the $\mathrm{mV}$ reading from the turbidity meter was lower than the target $\mathrm{mV}$ more sediment was added manually to the aquarium. The amount of sediment added was determined by the difference between the target SSC and the voltage reading, using the calibration curve (Fig. S2). Suspended sediment concentrations in each aquarium were also determined gravimetrically. Each week, three aliquots of $50 \mathrm{ml}$ were sampled from each chamber and filtered through pre-dried $\left(60{ }^{\circ} \mathrm{C}\right)$ and pre-weighed $25 \mathrm{~mm} \mathrm{GF} / \mathrm{F}$ (Whatman) filters and dried to constant weight at $60^{\circ} \mathrm{C}$.

\subsection{Experimental aquaria}

The experimental aquaria (38 1 in volume each) were a modification of the chambers used by Cummings et al. (2020), and were based on the vortex resuspension chamber design developed by Davies et al. (2009). The system consisted of a cylindrical tank, tapered at the base, that allowed sediment falling out of suspension to accumulate in a small sump area (Fig. 1). At the centre of each aquarium was a PVC pipe (80 mm diameter) with openings at the bottom to allow the sediment in. A motorised polycarbonate auger (200 mm length, triple spiral helix design) located at the bottom of the pipe agitated the settled sediment and facilitated its resuspension by creating an upward flow inside the pipe. The flow created was forced out through three holes $(27 \mathrm{~mm})$ located just below the water surface, allowing the sediment to be reintroduced to the aquaria. This also created a vortex flow inside the aquarium, allowing regular water mixing and retaining sediments in suspension. At the base of each aquarium was a plastic grid $\left(1 \mathrm{~cm}^{2}\right)$ on which the sponges sat in individual open top coarse mesh baskets, allowing the sediment to fall through and under them (Fig. 1).

Aquaria were supplied with seawater at a rate of approximately 1.51 $\mathrm{h}^{-1}$. An outflow pipe with a filter (polyester fibre) prevented the sediment being lost through the outflow water. This filter was cleared daily and any sediment retained was reintroduced to the aquarium.

\subsection{Sponge response measures}

Sponges were left for $48 \mathrm{~h}$ to acclimate in the experimental aquaria before sediment was added (experiment start, $\mathrm{T}_{0}$ ).

Respiration rate measurements, photographs and buoyant weights were taken after one day of sediment exposure $\left(\mathrm{T}_{1}\right)$ on one sponge per aquarium, and the sponges were returned to the aquaria. At the end of the experiment, after two weeks of sediment exposure $\left(\mathrm{T}_{\text {end }}\right)$, these

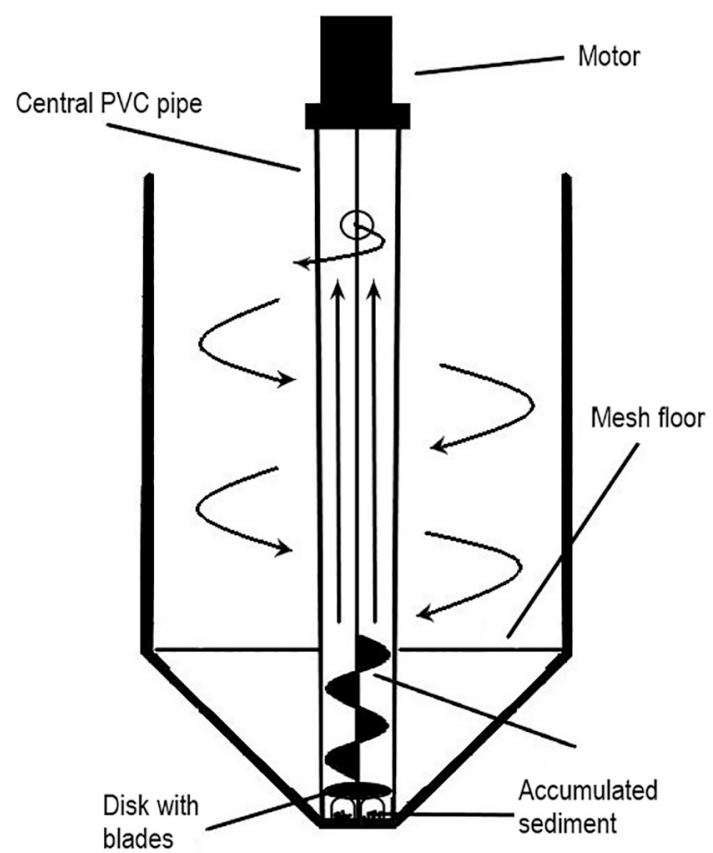

Fig. 1. Schematic representation of an experimental aquarium used in this study. Direction of water flow is shown by the arrows. The auger, driven by the motor, creates an upward water flow into the central PVC pipe. This flow resuspends and pushes the sediment accumulating at the bottom of the aquarium up the pipe and back into the chamber through the holes near the top of the pipe. The sponges sit in baskets on the mesh floor of the chamber.

measurements were made on the two sponges from each aquarium. Also at the end of the experiment, all sponges were sectioned, and photographs of the sections were taken to assess internal degradation (necrosis) and sediment accumulation.

\subsubsection{Respiration rates}

Respiration rates were measured at $\mathrm{T}_{1}$ and $\mathrm{T}_{\text {end }}$ in sealed 2.31 respiration chambers fitted with individual oxygen probes (D-Opto SDI Optical dissolved oxygen sensor). Mixing of the chamber water was achieved using a magnetic stir bar located in a separate compartment at the bottom of each chamber. The respiration chambers were immersed in a flow-through water bath to maintain constant water temperature $\left(\sim 10^{\circ} \mathrm{C}\right)$.

Sponges were added to the respiration chambers (one per chamber) and acclimated for 20 min before the chambers were sealed and dissolved oxygen (DO) readings started. Continuous measurements were taken for $30 \mathrm{~min}$. We could not detect if sponges were pumping with fluorescein dye, however we considered that the decline of DO over time was indicative that the sponges were pumping. We made sure that oxygen concentration inside the respiration chambers did not drop below $70 \%$ saturation. Blank incubations containing only seawater were used to correct for any microbial community respiration in the seawater. Respiration rates (mg O $\mathrm{O}_{2} \mathrm{~h}^{-1} \mathrm{l}^{-1} \mathrm{~g}^{-1}$ ash free dry weight (AFDW)) were determined after adjusting for the volume of water in the chamber and the sponge AFDW (which represents the organic component of the sponge tissue). AFDW was determined on sponges at $\mathrm{T}_{\text {end }}$ by oven drying the sponge $\left(60^{\circ} \mathrm{C}\right)$ to constant weight, and ashing $\left(500^{\circ} \mathrm{C}\right.$ for $\left.5 \mathrm{~h}\right)$. The relationship between sponge buoyant weight and AFDW at $\mathrm{T}_{\text {end }}$ was determined by performing a linear regression in order to obtain sponge AFDW at $T_{1}\left(R^{2}=0.94\right.$; Fig. S3).

\subsubsection{Necrosis}

Photographs of the sponges were taken using a Nikon D850 camera (50 mm lens). In order to detect any sign of degradation over the 
experiment, photographs taken at $\mathrm{T}_{0}, \mathrm{~T}_{1}$ and $\mathrm{T}_{\text {end }}$ were compared using ImageJ (Schneider et al., 2012). To detect the presence of internal necrosed tissue (identified as a darkening of the sponge tissue compared to healthy tissue), sponges were sectioned and photographed at $\mathrm{T}_{\text {end. }}$. A scale and grey colour bar were included in the photographs to aid the comparisons.

\subsection{Statistical analysis}

We investigated the effects of SSC treatment $\left(0,50,100,500 \mathrm{mg} \mathrm{l}^{-1}\right.$; see Section 3.1) and time ( $\left.\mathrm{T}_{1}, \mathrm{~T}_{\text {end }}\right)$ on sponge respiration rates using a linear mixed effects analysis in R. We used the lmer() function in the lme4 package to carry out the mixed model (Bates et al., 2015) and the anova() function in the lmerTest package to provide $P$-values and approximate degrees of freedom of the model (Kuznetsova et al., 2017). Equal variance and normal distribution assumptions were evaluated via analysis of the residuals. Variance and normality assumptions were tested with Levene's and Shapiro-Wilk test, respectively. Respiration rates were $\log (\mathrm{x}+1)$ transformed to meet normality assumptions. Fixed effects were treatment and time, with interaction terms; random effects were sponge (to account for repeated measures), entered with two levels of random effects (one associated with sponge donors, one associated with sponge clones; sponge 'clones' nested within sponge 'donors'), and aquaria (A01-A16). Aquarium effect was included to address pseudoreplication, as two sponges were located in each chamber. Alphanumeric ID were used for factors, and all factors were stated as such with the function 'as.factor()' in R. Respiration rate analyses were run on two different datasets: in the first, dead sponges $(n=1)$ and sponges with any level of partial necrosis $(n=6)$ were excluded, as they were considered physiologically compromised; in the second, dead sponges $(n=1)$ were excluded, and sponges with partial necrosis $(n=6)$ were included. Tukey post hoc pairwise comparisons were conducted for significant results to determine where significant differences between treatment groups existed. We performed a one-way ANOVA to test if the inorganic content of the treatment sponges was higher than the control as a result of more sediment incorporation. Statistical analyses were performed in $\mathrm{R}$ version 3.6.3 (R Core Team, 2020).

\section{Results}

\subsection{Sediment treatments}

Gravimetric analysis showed that the SSC in the chambers were on average $\sim 20 \mathrm{mg} \mathrm{l}^{-1}$ lower than the target concentrations (Fig. S4), i.e. $31.96 \pm 1.75 \mathrm{mg} \mathrm{l}^{-1}, 77.92 \pm 3.16 \mathrm{mg} \mathrm{l}^{-1}, 474.95 \pm 5.38 \mathrm{mg} \mathrm{l}^{-1}$ (mean \pm SE), cf. 50,100 and $500 \mathrm{mg} \mathrm{l}^{-1}$. Gravimetric analysis showed a background concentration of $0.98 \pm 0.08 \mathrm{mg} \mathrm{l}^{-1}$ in the control chambers (no sediment added). Hereafter, we use these measured mean SSCs: 1, $32,78,475 \mathrm{mg} \mathrm{l}^{-1}$.

\subsection{Sponge survival and health}

Survival was high with only one mortality noted, in the $475 \mathrm{mg} \mathrm{l}^{-1}$ treatment at $\mathrm{T}_{\text {end }}$. Sectioning of the sponges showed partial internal necrosis in six sponges across treatments: one control sponge, two sponges in the $78 \mathrm{mg} \mathrm{l}^{-1}$ treatment and three sponges in the $475 \mathrm{mg}^{-1}$ treatment (Fig. 2). The dead sponge and one with partial necrosis in the $475 \mathrm{mg} \mathrm{l}^{-1}$ treatment were from the same experimental aquaria; all other sponges with partial necrosis were in different aquaria. All other sponges appeared visibly healthy at $\mathrm{T}_{\text {end }}$.

\subsection{Respiration rates}

\subsubsection{Necrosed sponges excluded}

SSC had a significant effect on sponge respiration rates $\left(\mathrm{F}_{(3,23)}=\right.$ $3.85, p=0.0224$; Table 1 ), which were lower in sponges from the 475

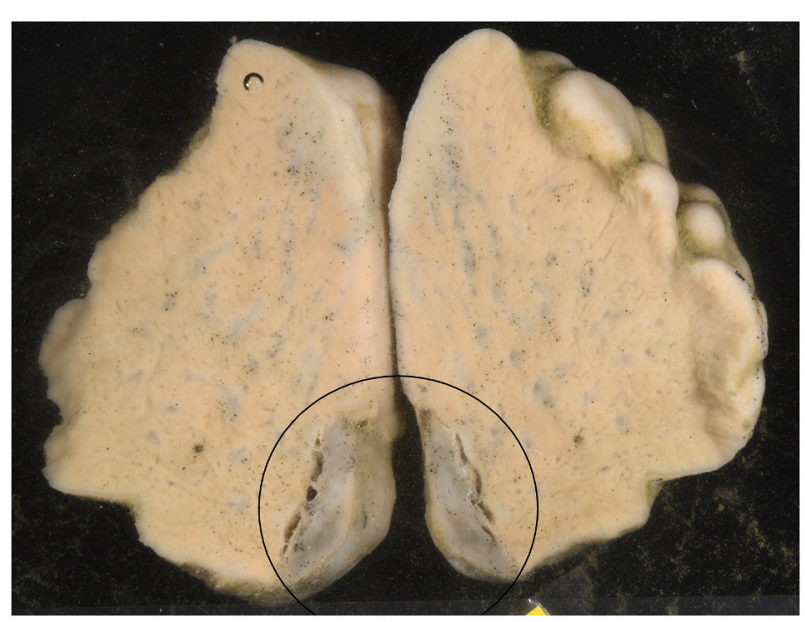

Fig. 2. Section of treatment sponge showing a portion of necrosed tissue (circled in black). This sponge was in the $475 \mathrm{mg} \mathrm{l}^{-1}$ SSC treatment.

Table 1

ANOVA table and summary of General Linear Mixed Model assessing the effects of SSC and time on respiration rates of Ecionemia novaezealandiae. A) dataset excluding necrotic sponges; B) dataset including necrotic sponges. DF = degrees of freedom, DFD = degrees of freedom denominator, $\mathrm{SS}=$ sum of squares, MS = mean squares. Significant values are shown in bold.

\begin{tabular}{|c|c|c|c|c|c|c|}
\hline & $\mathrm{DF}$ & DFD & SS & MS & F-value & $\operatorname{Pr}>\mathrm{F}$ \\
\hline \multicolumn{7}{|c|}{ A) Respiration rates (necrosed sponges excluded) } \\
\hline Treatment & 3 & 23.47 & 0.0035 & 0.0011 & 3.85 & 0.0224 \\
\hline Time & 1 & 22.98 & 0.0012 & 0.0012 & 4.11 & 0.0541 \\
\hline Treatment*Time & 3 & 22.78 & 0.0012 & 0.0004 & 1.33 & 0.2871 \\
\hline \multicolumn{7}{|c|}{ B) Respiration rates (necrosed sponges included) } \\
\hline Treatment & 3 & 12.77 & 0.0022 & 0.0007 & 2.67 & 0.0917 \\
\hline Time & 1 & 25.39 & 0.0012 & 0.0012 & 4.22 & 0.0501 \\
\hline Treatment*Time & 3 & 25.32 & 0.0015 & 0.0005 & 1.81 & 0.1699 \\
\hline
\end{tabular}

$\mathrm{mg} \mathrm{1}^{-1}$ treatment than in the control at $\mathrm{T}_{1}$ (Table S2). Mean respiration rates of the 32,78 and $475 \mathrm{mg}^{-1}$ treatment sponges at $\mathrm{T}_{1}$ decreased by 27,37 and $60 \%$, respectively, compared to the control sponges. At $\mathrm{T}_{\text {end }}$, treatment sponge respiration rates were lower by 7,17 and $27 \%$ in the 32,78 and $475 \mathrm{mg} \mathrm{l}^{-1}$ SSCs, respectively, compared to the control. Mean respiration rates of sponges in the $475 \mathrm{mg} \mathrm{l}^{-1}$ treatment were similar at $\mathrm{T}_{1}$ and $\mathrm{T}_{\text {end }}(0.086 \pm 0.0323$ vs $0.0962 \pm 0.0104$; mean $\pm \mathrm{SE})$. Respiration rates decreased at higher SSC, and this effect was stronger at $\mathrm{T}_{1}$ (Fig. 3A). At $\mathrm{T}_{1}$, sponge respiration rates were also more variable than at $\mathrm{T}_{\text {end. }}$. However, there was no significant effect of time $\left(\mathrm{F}_{(1,22)}=4.11, p=\right.$ 0.0541 ; Table 1$)$, and no time*treatment interaction ( $p>0.05$; Table 1$)$. Random effects of sponge and aquaria were small (Table S1).

\subsubsection{Necrosed sponges included}

SSC treatment and time had no significant effect on sponge respiration rates (Table 1 ). Mean respiration rates at $T_{1}$ were as described above for the data set excluding sponges with necrosed tissues (there were no necrosed sponges at $\mathrm{T}_{1}$ ), whereas, at $\mathrm{T}_{\text {end }}$, mean respiration rates of treatment sponges were lower by 7, 24 and $25 \%$ in the 32,78 and 475 $\mathrm{mg} \mathrm{l}^{-1}$ SSCs, respectively, compared to the controls (Fig. 3B). Respiration rates of sponges in the $475 \mathrm{mg} \mathrm{l}^{-1}$ treatment were more variable than those of the same treatment where sponges with necrosis were excluded (Fig. 3; $0.1 \pm 0.0285$ vs $0.0962 \pm 0.0104$; mean \pm SE). Random effects of sponge and aquaria were small (Table S1).

\subsection{Sediment incorporation}

Sponge sections revealed the presence of internal sediment in almost all sponges, including control sponges. Qualitative visual assessments 

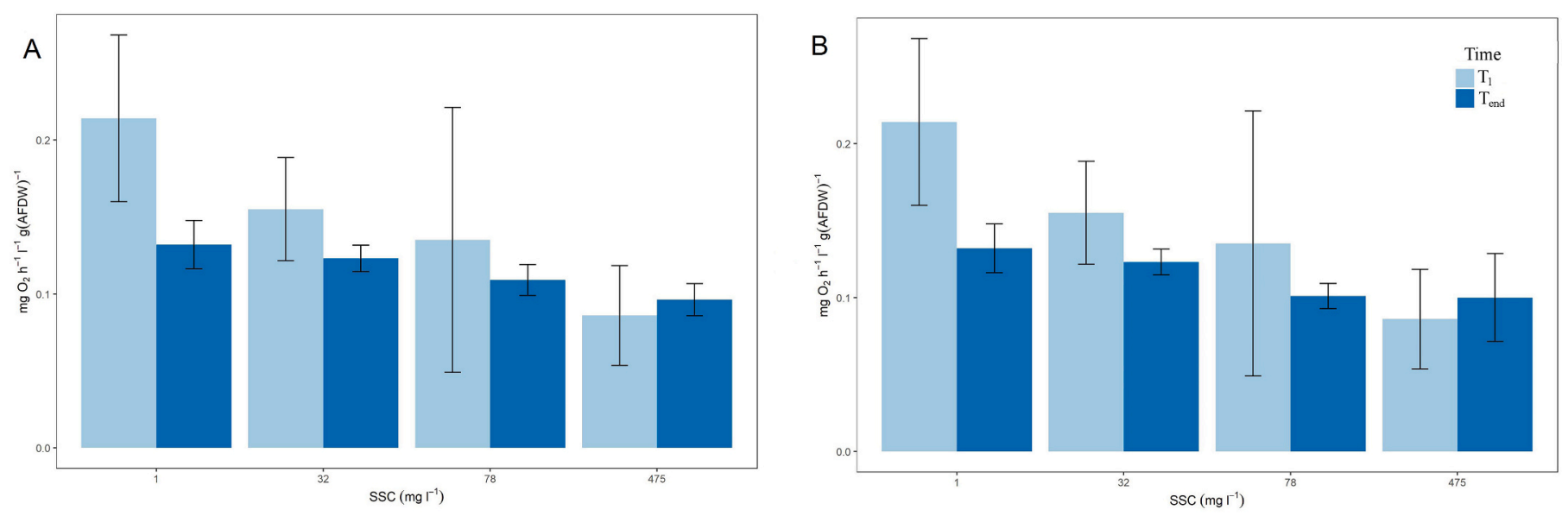

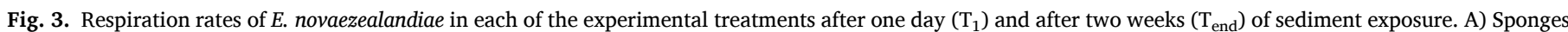
with partial necrosis are excluded; (B) sponges with partial necrosis are included. Bars show mean values \pm SE. $N=4$ per treatment, per time point.

showed that the presence and the amount of sediment incorporation was independent of the SSC treatments, with some control sponges having more sediment than treatment sponges (Fig. 4). Internal sediment grain sizes were larger than the sediment used in the experiment (e.g. up to 300-500 $\mu \mathrm{m}$; ImageJ). There was no significant difference between treatments in the inorganic content of the sponges $\left(\mathrm{F}_{(3,12)}=0.47, p=\right.$ 0.7046, Table 2; Fig. S5).

\section{Discussion}

Using a controlled laboratory experiment we investigated, for the first time, survival and physiological responses of the New Zealand deepsea sponge Ecionemia novaezealandiae to acute (one day) and two-weeks exposure to elevated suspended sediment concentrations. Despite the high survival, exposure to elevated SSCs had negative effects on this species, which included a reduction in respiration rates at both $\mathrm{T}_{1}$ and $\mathrm{T}_{\text {end }}$ and a decline in health, which manifested with partial necrosis at higher SSC at $\mathrm{T}_{\text {end. }}$.

\subsection{Survival and health}

Survival was high, with one death occurring in the highest SSC treatment (475 $\mathrm{mg} \mathrm{l}^{-1}$ ) after two weeks of sediment exposure. High survival rates have also been found in a shallow water New Zealand sponge exposed to elevated concentrations of natural sediments (up to $830 \mathrm{mg} \mathrm{l}^{-1}$ for 4 weeks; Cummings et al., 2020) and for Vazella pourtalesii over a three week period (Wurz et al., 2021). In contrast, Pineda et al. (2017) found elevated mortality rates $(90 \%)$ on a tropical shallow-
Table 2

Results of one-way ANOVA investigating the influence of the SSC treatment on E. novaezealandiae inorganic content. $\mathrm{DF}=$ degrees of freedom, $\mathrm{SS}=$ sum of squares, $\mathrm{MS}=$ mean square.

\begin{tabular}{llllll}
\hline & DF & SS & MS & F & $\operatorname{Pr}(>\mathrm{F})$ \\
\hline Treatment & 3 & 4.965 & 1.6549 & 0.47 & 0.7046 \\
Residuals & 12 & 41.693 & 3.4744 & & \\
\hline
\end{tabular}

water sponge exposed to $100 \mathrm{mg}^{-1} \mathrm{SSC}$, and low mortality rates at much lower SSCs (10 and $30 \mathrm{mg} \mathrm{l}^{-1}$ ). In that study, however, sponges were exposed to finely ground sediments $(3-65 \mu \mathrm{m})$, which differed from those in their natural environment (Pineda et al., 2017), unlike E. novaezealandiae in the present study, which was exposed to natural sediments. These contrasting findings confirm that sponge sensitivity to sediment is highly dependent on sediment properties, as well as sponge species.

In our study, the percentage of sponges affected by partial necrosis increased in the highest SSC treatments, as also observed in the tropical shallow-water sponges Carteriospongia foliascens, Cliona orientalis, and Coscinoderma matthewsi after exposure to 4 weeks of SSCs up to $100 \mathrm{mg}$ $1^{-1}$ (Pineda et al., 2017). Two of the six sponges with partial necrosis in our experiment (one control sponge and one sponge in the $78 \mathrm{mg}^{-1}$ treatment) had originated from the same donor sponge, so it is possible that this sponge was unhealthy at the start of the experiment. Similar low levels of necrosis have been reported in control sponges from other experiments where sponges were collected by divers (e.g. Biggerstaff et al., 2017) or by ROV (Wurz et al., 2021). The remaining four sponges

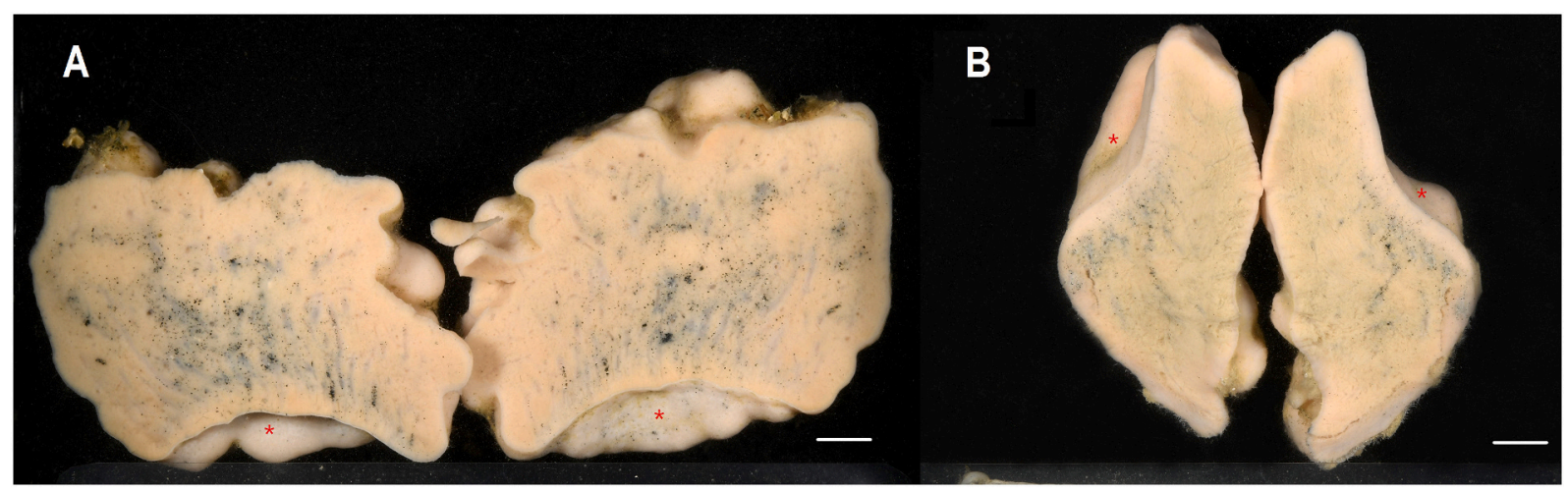

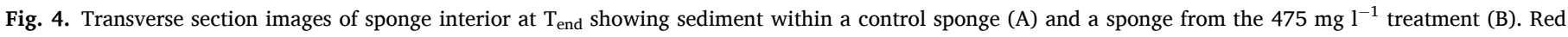
asterisks indicate sponge upper surface. Scale bar $=1 \mathrm{~cm}$. 
exhibiting necrosis were from the $78 \mathrm{mg} \mathrm{l}^{-1}$ (1 sponge) or $475 \mathrm{mg} \mathrm{l}^{-1}$ (3 sponges) SSC treatments.

\subsection{Respiration rates}

Respiration rates showed similar patterns between the two datasets excluding and including necrosed sponges, however, they were more variable in the $475 \mathrm{mg}^{-1} \mathrm{SSC}$ treatment sponges of the second dataset. When sponge tissue becomes necrotic, sponges experience significant changes in their microbiota both in the necrotic area and in the apparently healthy area adjacent the necrotic area (Pita et al., 2018), thus compromising sponge physiology measurements and potentially misrepresenting sponge health status. For this reason, here we only discuss results from the first dataset, where necrosed sponge respiration rates were excluded.

Respiration rates in E. novaezealandiae decreased with elevated SSCs, which is consistent with responses reported for the deep-sea sponges Geodia barretti and G. atlantica (Tjensvoll et al., 2013; Kutti et al., 2015; Scanes et al., 2018) and for some shallow water temperate (Aaptos spp.; Lohrer et al., 2006) and tropical sponges (C. foliascens, C. orientalis, Stylissa flabelliformis; Pineda et al., 2017). Tjensvoll et al. (2013) and Kutti et al. (2015) reported a 50\% and 67\% decline in respiration rate, respectively, in $G$. barretti after $4 \mathrm{~h}$ exposure of $500 \mathrm{mg}^{-1} \mathrm{SSC}$; similarly, E. novaezealandiae exposed to $475 \mathrm{mg}^{-1} \mathrm{SSC}$ had reduced its respiration rates by $60 \%$ at $\mathrm{T}_{1}$. The smaller variability in sponge respiration rates at $\mathrm{T}_{\text {end }}$ (14 days) indicates that sponges may have adopted a strategy to cope with the SSCs. Wurz et al. (2021) reported a slight increase in respiration rates over a period of 21 days for Vazella pourtesii. Our study is the first to expose deep-sea sponges to SSC $>50 \mathrm{mg}^{-1}$ for a period longer than a few hours, therefore our results obtained at $\mathrm{T}_{\text {end }}$ cannot readily be compared with other studies on deep-sea sponges.

A reduction in oxygen consumption in response to sediment exposure has been linked to reduced or arrested pumping rates in order to prevent sediment from entering the sponge and clogging the aquiferous system (Gerrodette and Flechsig, 1979; Bell et al., 2015). Pumping arrest or reduction has been widely observed in sponges as a response to sediment exposure (Tompkins-Mac Donald and Leys, 2008; Gerrodette and Flechsig, 1979; Grant et al., 2018; Grant et al., 2019; Reiswig, 1971; Strehlow et al., 2016). Pumping is an essential process for sponges to obtain oxygen and food particles, and so a reduction/cessation of pumping in response to sediment may be initiated to prevent clogging of inhalant canals. However, it is likely that reduced pumping activity impairs sponges feeding efficiency (see Lohrer et al., 2006 for discussion of reduction in sponge clearance rates). Although we were not able to directly assess E. novaezealandiae pumping activity, we propose that the lower respiration rates that we observed in high SSC treatments were due to a reduction in pumping rates. Along with decreased respiration rates, we observed internal necrosis in sponges exposed to SSC of 78 and $475 \mathrm{mg} \mathrm{l}^{-1}$, which could be a consequence of prolonged reduction in pumping. Hoffmann et al. (2008) described that during arrested pumping, only a thin surface layer receives oxygen from molecular diffusion, and reduced or arrested pumping for a prolonged period could lead to partial necrosis due to the lack of oxygenation is some tissue portions.

In contrast to our observations, respiration rates in the shallow water tropical sponges Rhophaloides orodabile and Xestospongia testudinaria increased in response to suspended sediments (Bannister et al., 2012; McGrath et al., 2017). Similarly, Biggerstaff et al. (2017) reported increased respiration rates in another shallow tropical sponge Lamellodysidea herbacea exposed to settled sediment. These species produced mucus when exposed to sediments for a short period (Bannister et al., 2012; Biggerstaff et al., 2017; McGrath et al., 2017), identified as a mechanism to trap sediment thus preventing smothering of inhalant pores (Bannister et al., 2012). Mucus production is likely to have high energetic demand, hence it would explain the increase in respiration rates (Bell et al., 2015). Mucus production by E. novaezealandiae was not observed in our experiment.

Although we could not directly measure sponge pumping, preexperiment respiration trials showed that sponges were depleting oxygen and therefore likely pumping. The respiration rates reported in control sponges were comparable, and even higher, than respiration rates reported in pumping specimens of the deep-sea sponge Geodia spp. In different experiments with Geodia spp., mean oxygen consumption rates of sponges from control conditions were $\sim 0.022 \mathrm{mg} \mathrm{h}^{-1} \mathrm{~g}^{-1}$ (DW) (Scanes et al., 2018), $\sim 0.054 \mathrm{mg} \mathrm{h}^{-1} \mathrm{~g}^{-1}$ (DW) (Kutti et al., 2015) and 0.054-0.073 $\mathrm{mg} \mathrm{h}^{-1} \mathrm{~g}^{-1}$ (DW) (Tjensvoll et al., 2013). Mean oxygen consumption rates in our control sponges were $0.13-0.2 \mathrm{mg} \mathrm{h}^{-1} \mathrm{l}^{-1} \mathrm{~g}^{-1}$ (AFDW). If sponges were not pumping, oxygen consumption rates would have been expected to be much lower.

\subsection{Sediment incorporation}

Visual observations of sponge sections showed the presence of sediment inside the sponge tissues, although there was no correlation between the presence/amount of sediment accumulated and SSC treatment. This observation was corroborated by the absence of a relationship between sponge inorganic content (percentage of ash weight) and sediment treatments. Sponge inorganic content is made up of sponge spicules and, in this case, accumulated sediment. Assuming that sponge spicule content does not vary between treatments after such a short period, we expected that any differences in sponge inorganic content would reflect sediment accumulation between treatments. However, as we did not separate spicules from sediment, we cannot rule this out. Accumulation of sediment in sponges exposed to sediments in experimental conditions has been shown in Crella incrustans (Cummings et al., 2020) and Ianthella basta (Strehlow et al., 2017), but only in sediment treatment sponges. In our study, several control sponges showed quantities of sediment similar to sponges from the SSC treatments. Sediments were dispersed in the sponge tissue, e.g. they were not located in a specific portion of the sponge. The presence of sediments in control sponges and their particle size indicates that these sediments had been accumulated in their natural environment (we sieved the sediment, $<150 \mu \mathrm{m}$, so any larger particles would have originated from their natural environment). As sponges undergo continuous reorganization of tissues (Alexander et al., 2014), it is not possible to determine at which life stage they might have accumulated sediments. Some sponge species are known to actively take up and incorporate sediments and, in some cases, sediment incorporation can enhance growth and provide structural support (Schönberg, 2016). Others also incorporate sand, larger particles and pebbles basally with the function of anchoring (Schönberg, 2016 and references therein). It remains unknown if $E$. novaezealandiae passively or actively accumulates sediment internally (and if the latter, what the function of these sediments might be). A possibility is that the internal sediment was a result of the trawling disturbance during collection of the specimens. However, we believe this to be unlikely given that efforts were made to keep the trawl tows short (10-15 min on the bottom, 0.2-0.3 nautical miles length) and trawl speeds were low (1-1.5 knots) to reduce disturbance of the seafloor sediments. Furthermore, if sponges had accumulated sediment during trawling, this sediment would have been expected close to the sponge surface, not scattered much deeper internally (see Fig. 4). In this study, we observed a large quantity of sediments in control sponges seven weeks after their collection, however we do not know how this amount compared with the immediate post-collection period. This might indicate that: a) these sponges were not able to clear the sediment they had internally accumulated or b) they actively incorporate sediment for one of the reasons described above.

\section{Conclusions}

This study demonstrates that the deep-sea New Zealand sponge E. novaezealandiae has a rapid response to elevated SSC, with reduced 
respiration rates of up to $60 \%$ after just one day of sediment exposure. Despite the fact that the sediment concentrations used in our study were much higher than those in most previous experiments on sponges, only one mortality event was observed (albeit at the highest SSC). The presence of sediment particles incorporated within the control sponge tissues is evidence that this species is exposed to sediments in its natural environment. However, the sublethal effects we observed (necrosed tissues and decreased respiration rates) indicates an increasing decline of sponge health at higher SSCs that may be potentially serious to the health of $E$. novaezealandiae beyond the experimental period, and may be exacerbated depending on the life stage at which the SSC exposure occurs. Tolerance of sponges to SSC is highly dependent on species, sediment quality, and location, thus caution is advised in generalising our conclusions from a two-week experiment to other deep-sea species and areas.

\section{Declaration of Competing Interest}

The authors declare that they have no known competing financial interests or personal relationships that could have appeared to influence the work reported in this paper.

\section{Acknowledgements}

We would like to thank Sandeep Beepat (Victoria University of Wellington, VUW) for helping with the final sampling; Neill Barr and Jennifer Beaumont (National Institute of Water and Atmospheric Research, NIWA) for designing the experimental chambers, Jennifer Beaumont and Graeme Moss (NIWA) for helping with the set up of the experiment; Peter Marriott and Rob Stewart (NIWA) for helping with the photography set up; Lisa Woods (VUW) for providing statistical advice. We also acknowledge the crew on board RV Tangaroa Voyage TAN1903 for their help with the live specimen samples. Ship time for the voyage was awarded by the Tangaroa Reference Group (TRG) and funded by the Ministry for Business, Innovation and Employment (MBIE) (MBIE contract CO1X1614). This research was funded by a Victoria University of Wellington doctoral scholarship and by the 'Resilience of benthic communities to the effects of sedimentation' (ROBES) programme.

\section{Appendix A. Supplementary data}

Supplementary data to this article can be found online at https://doi. org/10.1016/j.jembe.2021.151579.

\section{References}

Alexander, B.E., Liebrand, K., Osinga, R., van der Geest, H.G., Admiraal, W., Cleutjens, J. P., Schutte, B., Verheyen, F., Ribes, M., van Loon, E., de Goeij, J.M., 2014. Cell turnover and detritus production in marine sponges from tropical and temperate benthic ecosystems. PLoS One 9 (10), e109486.

Bannister, R.J., Battershill, C.N., De Nys, R., 2012. Suspended sediment grain size and mineralogy across the continental shelf of the great barrier reef: impacts on the physiology of a coral reef sponge. Cont. Shelf Res. 32, 86-95.

Bates, D., Mäechler, M., Bolker, B., Walker, S., 2015. Fitting linear mixed-effects models using lme4. J. Stat. Softw. 67, 1-48. https://doi.org/10.18637/jss.v067.i01.

Bell, J.J., 2008. The functional roles of marine sponges. Estuar. Coast. Shelf Sci. 79, 341-353.

Bell, J.J., McGrath, E., Biggerstaff, A., Bates, T., Bennett, H., Marlow, J., Shaffer, M., 2015. Sediment impacts on marine sponges. Mar. Pollut. Bull. 94, 5-13.

Bennett, H.M., Altenrath, C., Woods, L., Davy, S.K., Webster, N.S., Bell, J.J., 2017. Interactive effects of temperature and $\mathrm{pCO}_{2}$ on sponges: from the cradle to the grave. Glob. Change Biol. 23, 2031-2046.

Biggerstaff, A., Smith, D.J., Jompa, J., Bell, J.J., 2017. Metabolic responses of a phototrophic sponge to sedimentation supports transitions to sponge-dominated reefs. Sci. Rep. 7, 1-11.

Black, J., Wood, R.A., Berthelsen, T., Tilney, R.L., 2013. Monitoring New Zealand's Trawl Footprint for Deepwater Fisheries: 1989-90 to 2009-10. Ministry for Primary Industries.

Blott, S.J., 2010. GRADISTAT Ver. 8.0: a grain size distribution and statistics package for the analysis of unconsolidated sediments by sieving or laser Granulometer. Kenneth Pye associates ltd, UK. www.kpal.co.uk/gradistat.html.
Boschen, R.E., Rowden, A.A., Clark, M.R., Pallentin, A., Gardner, J.P., 2016. Seafloor massive sulfide deposits support unique megafaunal assemblages: implications for seabed mining and conservation. Mar. Environ. Res. 115, 78-88.

Bowden, D.A., Davey, N., Fenwick, M., George, S., Macpherson, D., Ray, C., Stewart, R., Christensen-Field, C., Gibson, K., 2017. Quantifying benthic biodiversity: a factual voyage report from RV Tangaroa voyage TAN1701 to Chatham rise. New Zealand aquatic environment and biodiversity report no. 185 (ISSN 1179-6480). Ministry for Primary Industries, Wellington, New Zealand.

Bradshaw, C., Tjensvoll, I., Sköld, M., Allan, I.J., Molvaer, J., Naes, K., Nilsson, H.C., 2012. Bottom trawling resuspends sediment and releases bioavailable contaminants in a polluted fjord. Environ. Pollut. 170, 232-241.

Cathalot, C., Van Oevelen, D., Cox, T.J.S., Kutti, T., Lavaleye, M., Duineveld, G., Meysman, F.J.R., 2015. Cold-water coral reefs and adjacent sponge grounds: hotspots of benthic respiration and organic carbon cycling in the deep sea. Front. Mar. Sci. 2, 37. https://doi.org/10.3389/fmars.2015.00037.

Chu, J.W., Maldonado, M., Yahel, G., Leys, S.P., 2011. Glass sponge reefs as a silicon sink. Mar. Ecol. Prog. Ser. 441, 1-14.

Clark, M.R., Dunn, M.R., 2012. Spatial management of deep-sea seamount fisheries: balancing sustainable exploitation and habitat conservation. Environ. Conserv. 39, 204-214.

Clark, R.M., Althaus, F., Schlacher, T.A., Williams, A., Bowden, D.A., Rowden, A.A., 2016. The impacts of deep-sea fisheries on benthic communities: a review. ICES J. Mar. Sci. 73, 151-169. https://doi.org/10.1093/icesjms/fsv123.

Clark, M.R., Nodder, S., O'Callaghan, J., Browne, R., Daymond, A., de Joux, P., George, S., Hale, R., Hart, A., Jhugroo, K., Leduc, D., Mobilia, V., Price, O., Searson, S., Solomon, C., Stewart, R., Tracey, D., 2019. Resilience of Deep-Sea Benthic Communities to the Effects of Sedimentation ("ROBES"): Voyage Report of Survey 2: June 2019. Unpublished NIWA voyage report, 74 p. https://niwa.co.nz/s ites/niwa.co.nz/files/ROBES2_VoyageReport_2November2019-NIWA.pdf.

Core Team, R., 2020. R: A language and environment for statistical computing. In: R Foundation for Statistical Computing, Vienna, Austria. URL. https://www.R-pro ject.org/.

Cummings, V.J., Beaumont, J., Mobilia, V., Bell, J.J., Tracey, D., Clark, M.R., Barr, N., 2020. Responses of a common New Zealand coastal sponge to elevated suspended sediments: indications of resilience. Mar. Environ. Res. 155, 104886.

Davies, A.J., Last, K.S., Attard, K., Hendrick, V.J., 2009. Maintaining turbidity and current flow in laboratory aquarium studies, a case study using Sabellaria spinulosa. J. Exp. Mar. Biol. Ecol. 370, 35-40.

Deltares, 2014. Modelling investigations on mine tailing plume dispersion on the Chatham Rise. In: Deltares Final Report 1209110-000-ZKS-0007 (57 pp).

Durrieu de Madron, X., Ferré, B., Le Corre, G., Grenz, C., Conan, P., Pujo-Pay, M., Buscail, R., Bodiot, O., 2005. Trawling-induced resuspension and dispersal of muddy sediments and dissolved elements in the Gulf of lion (NW Mediterranean). Cont. Shelf Res. 25, 2387-2409.

Ellis, J., Cummings, V., Hewitt, J., Thrush, S., Norkko, A., 2002. Determining effects of suspended sediment on condition of a suspension feeding bivalve (Atrina zelandica): results of a survey, a laboratory experiment and a field transplant experiment. J. Exp. Mar. Biol. Ecol. 267, 147-174.

Ellis, J.I., Clark, M.R., Rouse, H.L., Lamarche, G., 2017. Environmental management frameworks for offshore mining: the New Zealand approach. Mar. Policy 84, $178-192$.

FAO, 2009. Report of the technical consultation on international guidelines for the management of deep-sea fisheries in the high seas. In: Fisheries and Aquaculture Report No. 881. FAO, Rome, Italy, p. 98.

Ferré, B., De Madron, X.D., Estournel, C., Ulses, C., Le Corre, G., 2008. Impact of natural (waves and currents) and anthropogenic (trawl) resuspension on the export of particulate matter to the open ocean: application to the Gulf of lion (NW Mediterranean). Cont. Shelf Res. 28, 2071-2091.

Fisheries New Zealand, 2020. Fisheries Assessment Plenary, May 2020. Stock Assessment and Stock Status.

Fosså, S.A., Nilsen, A.J., 1996. Korallenriff-Aquarium, Band 5. Einzellige Organismen, Schwämme, marine Würmer und Weichtiere im Korallenriff und für das KorallenriffAquarium. Kapittel 3: Schwämme, 35-65. Birgit Schmettkamp Verlag, Bornheim.

Gerrodette, T., Flechsig, A.O., 1979. Sediment-induced reduction in the pumping rate of the tropical sponge Verongia lacunosa. Mar. Biol. 55, 103-110.

Glover, A.G., Smith, C.R., 2003. The deep-sea floor ecosystem: current status and prospects of anthropogenic change by the year 2025. Environ. Conserv. 30, 219-241.

Gollner, S., Kaiser, S., Menzel, L., Jones, D.O., Brown, A., Mestre, N.C., van Oevelen, D., Menot, L., Colaço, A., Canals, M., Cuvelier, D., Durden, M.J., Gebruk, A., Egho, A.G., Haeckel, M., Marcon, Y., Mevenkamp, L., Morato, T., Pham, C.K., Purser, A., Sanchez-Vidal, A., Vanreusel, A., Vink, A., Martinez Arbizy, P., 2017. Resilience of benthic deep-sea fauna to mining activities. Mar. Environ. Res. 129, 76-101.

Grant, N., Matveev, E., Kahn, A.S., Leys, S.P., 2018. Suspended sediment causes feeding current arrests in situ in the glass sponge Aphrocallistes vastus. Mar. Environ. Res. 137, 111-120.

Grant, N., Matveev, E., Kahn, A.S., Archer, S.K., Dunham, A., Bannister, R.J., ErrkesMedrano, D., Leys, S.P., 2019. Effect of suspended sediments on the pumping rates of three species of glass sponge in situ. Mar. Ecol. Prog. Ser. 615, 79-100.

Hall-Spencer, J., Allain, V., Fossa, J.H., 2002. Trawling damage to Northeast Atlantic ancient coral reefs. Proc. Biol. Sci. 269, 507-511.

Hewitt, J.E., Norkko, J., 2007. Incorporating temporal variability of stressors into studies: an example using suspension-feeding bivalves and elevated suspended sediment concentrations. J. Exp. Mar. Biol. Ecol. 341, 131-141.

Hoffmann, F., Røy, H., Bayer, K., Hentschel, U., Pfannkuchen, M., Brümmer, F., De Beer, D., 2008. Oxygen dynamics and transport in the Mediterranean sponge Aplysina aerophoba. Mar. Biol. 153, 1257-1264. 
Hourigan, T.F., Etnoyer, P.J., Cairns, S.D., 2017. The State of Deep-Sea Coral and Sponge Ecosystems of the United States. US Department of Commerce, National Oceanic and Atmospheric Administration, National Marine Fisheries Service.

Kahn, A.S., Yahel, G., Chu, J.W., Tunnicliffe, V., Leys, S.P., 2015. Benthic grazing and carbon sequestration by deep-water glass sponge reefs. Limnol. Oceanogr. 60, 78-88.

Kelly, M., Sim-Smith, C., 2012. A review of Ancorina, Stryphnus, and Ecionemia (Demospongiae: Astrophorida: Ancorinidae), with descriptions of new species from New Zealand waters. Zootaxa 3480, 1-47.

Klitgaard, A.B., Tendal, O.S., 2004. Distribution and species composition of mass occurrences of large-sized sponges in the Northeast Atlantic. Prog. Oceanogr. 61, $57-98$.

Kutti, T., Bannister, R.J., Fosså, J.H., Krogness, C.M., Tjensvoll, I., Søvik, G., 2015 Metabolic responses of the deep-water sponge Geodia barretti to suspended bottom sediment, simulated mine tailings and drill cuttings. J. Exp. Mar. Biol. Ecol. 473, 64-72.

Kuznetsova, A., Brockhoff, P.B., Christensen, R.H., 2017. lmerTest package: tests in linear mixed effects models. J. Stat. Softw. 82, 1-26.

Lepland, A., Mortensen, P.B., 2008. Barite and barium in sediments and coral skeletons around the hydrocarbon exploration drilling site in the Træna deep, Norwegian Sea Environ. Geol. 56, 119-129. https://doi.org/10.1007/s00254-007-1145-4.

Levin, L.A., Mengerink, K., Gjerde, K.M., Rowden, A.A., Van Dover, C.L., Clark, M.R., Ramirez-Llodra, E., Currie, B., Smith, C.R., Sato, K.N., Gallo, N., Sweetman, A.K., Lily, H., Armstrong, C.W., Brider, J., 2016. Defining "serious harm" to the marine environment in the context of deep-seabed mining. Mar. Policy 74, 245-259.

Lohrer, A.M., Hewitt, J.E., Thrush, S.F., 2006. Assessing far-field effects of terrigenous sediment loading in the coastal marine environment. Mar. Ecol. Prog. Ser. 315, 13-18.

Longo, C., Mastrototaro, F., Corriero, G., 2005. Sponge fauna associated with a Mediterranean deep-sea coral bank. J. Mar. Biol. Assoc. U. K. 85, 1341-1352.

Maldonado, M., Carmona, M.C., Velásquez, Z., Puig, A., Cruzado, A., López, A., Young, C. M., 2005. Siliceous sponges as a silicon sink: an overlooked aspect of benthopelagic coupling in the marine silicon cycle. Limnol. Oceanogr. 50, 799-809.

Maldonado, M., Giraud, K., Carmona, C., 2008. Effects of sediment on the survival of asexually produced sponge recruits. Mar. Biol. 154, 631-641.

Maldonado, M., Aguilar, R., Bannister, R.J., Bell, J.J., Conway, K.W., Dayton, P.K., Díaz, C., Gutt, J., Kelly, M., Kenchington, E.L., Leys, S.P., 2017. Sponge Grounds as Key Marine Habitats: A Synthetic Review of Types, Structure, Functional Roles, and Conservation Concerns. Marine Animal Forests. The Ecology of Benthic Biodiversity Hotspots. http://www.springer.com/us/book/9783319210117.

McGrath, E.C., Smith, D.J., Jompa, J., Bell, J.J., 2017. Adaptive mechanisms and physiological effects of suspended and settled sediment on barrel sponges. J. Exp. Mar. Biol. Ecol. 496, 74-83.

Mengerink, K.J., Van Dover, C.L., Ardron, J., Baker, M., Escobar-Briones, E., Gjerde, K., Koslow, J.A., Ramirez-Llodra, E., Lara-Lopez, A., Squires, D., Sutton, A.K., Levin, L. A., 2014. A call for deep-ocean stewardship. Science 344, 696-698.

Miller, D.C., Muir, C.L., Hauser, O.A., 2002. Detrimental effects of sedimentation on marine benthos: what can be learned from natural processes and rates? Ecol. Eng. 19, 211-232

Murillo, F.J., Muñoz, P.D., Cristobo, J., Ríos, P., González, C., Kenchington, E., Serrano, A., 2012. Deep-sea sponge grounds of the Flemish cap, Flemish pass and the grand banks of Newfoundland (Northwest Atlantic Ocean): distribution and species composition. Mar. Biol. Res. 8, 842-854. https://doi.org/10.1080/ 17451000.2012 .682583$.

Nava, H., Carballo, J.L., 2013. Environmental factors shaping boring sponge assemblages at Mexican Pacific coral reefs. Mar. Ecol. 34, 269-279.

NZ EPA, 2015. Decision on Marine Consent Application Chatham Rock Phosphate Limited to Mine Phosphorite Nodules on the Chatham Rise. Available online at. https://cer.org.za/wp-content/uploads/2016/08/EPA-New-Zealand-Chatham-Roc k-Phosphate-Decision.pdf.

Osinga, R., Tramper, J., Wijffels, R.H., 1999. Cultivation of marine sponges. Mar. Biotechnol. 6, 509-532.

Palanques, A., Guillén, J., Puig, P., 2001. Impact of bottom trawling on water turbidity and muddy sediment of an unfished continental shelf. Limnol. Oceanogr. 46, 1100-1110.
Parsons, D., Tuck, I., Jones, E., Baird, S., Bagley, N., Neil, H., 2013. Potential for sediment suspension from trawl activity on the Chatham rise. In: NIWA Client Report No. WLG2013-61.

Pham, C.K., Murillo, F.J., Lirette, C., Maldonado, M., Colaço, A., Ottaviani, D., Kenchington, E., 2019. Removal of deep-sea sponges by bottom trawling in the Flemish cap area: conservation, ecology and economic assessment. Sci. Rep. 9, 1-13. https://doi.org/10.1038/s41598-019-52250-1.

Pile, A.J., Young, C.M., 2006. The natural diet of a hexactinellid sponge: benthic-pelagic coupling in a deep-sea microbial food web. Deep Sea Res. Part I: Oceanogr. Res. Pap. $53,1148-1156$.

Pineda, M.C., Strehlow, B., Sternel, M., Duckworth, A., Jones, R., Webster, N.S., 2017. Effects of suspended sediments on the sponge holobiont with implications for dredging management. Sci. Rep. 7, 4925.

Pita, L., Rix, L., Slaby, B.M., Franke, A., Hentschel, U., 2018. The sponge holobiont in a changing ocean: from microbes to ecosystems. Microbiome 1, 1-18.

Ramirez-Llodra, E., Trannum, H.C., Evenset, A., Levin, L.A., Andersson, M., Finne, T.E., Hilaro, A., Flem, B., Christensen, G., Schaanning, M., Vanreusel, A., 2015. Submarine and deep-sea mine tailing placements: a review of current practices, environmental issues, natural analogs and knowledge gaps in Norway and internationally. Mar. Pollut. Bull. 97, 13-35.

Reiswig, H.M., 1971. In situ pumping activities of tropical Demospongiae. Mar. Biol. 9, 38-50.

Robertson, L.M., Hamel, J.F., Mercier, A., 2017. Feeding in deep-sea demosponges: influence of abiotic and biotic factors. Deep Sea Res. Part I: Oceanogr. Res. Pap. 127, 49-56.

Rolinski, S., Segschneider, J., Sundermann, J., 2001. Long-term propagation of tailings from deep-sea mining under variable conditions by means of numerical simulations. Deep-Sea Res. II 48, 3469-3485.

Scanes, E., Kutti, T., Fang, J.K., Johnston, E.L., Ross, P.M., Bannister, R.J., 2018. Mine waste and acute warming induce energetic stress in the deep-sea sponge Geodia atlantica and coral Primnoa resedeaformis; results from a mesocosm study. Front. Mar. Sci. 5, 129.

Schneider, C.A., Rasband, W.S., Eliceiri, K.W., 2012. NIH image to ImageJ: 25 years of image analysis. Nat. Methods 9, 671-675.

Schoellhamer, D.H., 1996. Anthropogenic sediment resuspension mechanisms in a shallow microtidal estuary. Estuar. Coast. Shelf Sci. 43, 533-548.

Schönberg, C.H.L., 2016. Happy relationships between marine sponges and sediments-a review and some observations from Australia. J. Mar. Biol. Assoc. U.K. 96, 493-514.

Strehlow, B.W., Jorgensen, D., Webster, N.S., Pineda, M.C., Duckworth, A., 2016. Using a thermistor flowmeter with attached video camera for monitoring sponge excurrent speed and oscular behaviour. PeerJ 4, e2761.

Strehlow, B.W., Pineda, M.C., Duckworth, A., Kendrick, G.A., Renton, M., Wahab, M.A. A., Webster, N.S., Clode, P.L., 2017. Sediment tolerance mechanisms identified in sponges using advanced imaging techniques. PeerJ 5, e3904.

Tjensvoll, I., Kutti, T., Fosså, J.H., Bannister, R.J., 2013. Rapid respiratory responses of the deep-water sponge Geodia barretti exposed to suspended sediments. Aquat. Biol. 19, 65-73.

Tompkins-Mac Donald, G.J., Leys, S.P., 2008. Glass sponges arrest pumping in response to 48. Sediment: implications for physiology of the hexactinellid conduction system. Mar. Biol. 154, 973-984.

Tracey, D.M., Rowden, A.A., Mackay, K.A., Compton, T., 2011. Habitat-forming coldwater corals show affinity for seamounts in the New Zealand region. Mar. Ecol. Prog. Ser. 430, 1-22.

Wurz, E., Beazley, L., MacDonald, B., Kenchington, E., Rapp, H.T., Osinga, R., 2021. The hexactinellid deep-water sponge Vazella pourtalesii (Schmidt, 1870) (Rossellidae) copes with temporarily elevated concentrations of suspended natural sediment. Front. Mar. Sci. 8, 269. https://doi.org/10.3389/fmars.2021.611539.

Xavier, J.R., Tojeira, I., Van Soest, R.W.M., 2015. On a hexactinellid sponge aggregation at the great meteor seamount (north-East Atlantic). J. Mar. Biol. Assoc. U.K. 95, 1389-1394.

Yahel, G., Eerkes-Medrano, D.I., Leys, S.P., 2006. Size independent selective filtration of ultraplankton by hexactinellid glass sponges. Aquat. Microb. Ecol. 45, 181-194. 